\title{
Bibliography of the Seasonal Thermal Energy Storage Library
}

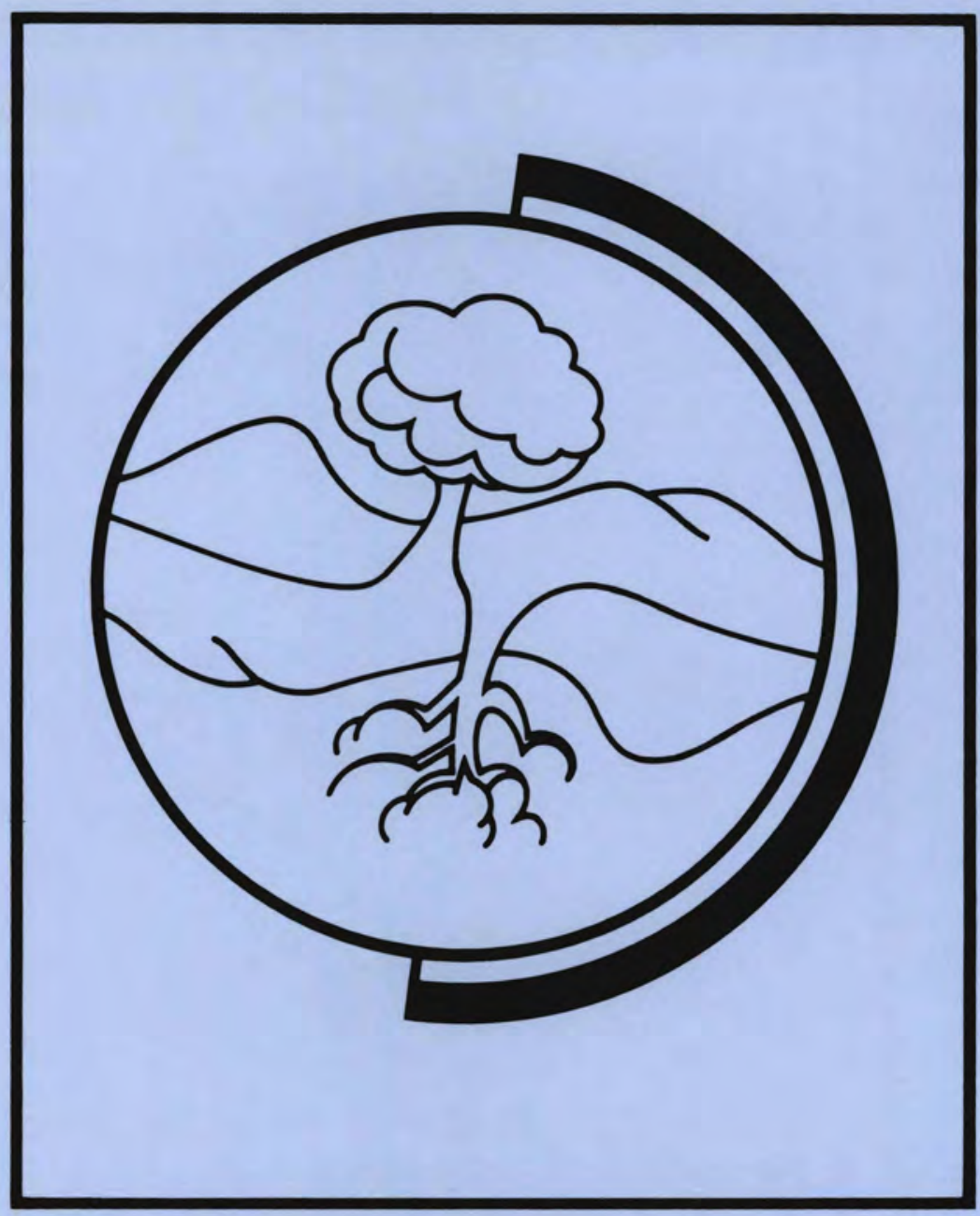

Prepared for the U.S. Department of Energy Office of Energy Systems Research Under Contract DE-AC06-76RLO 1830

Pacific Northwest Laboratory Operated for the U.S. Department of Energy by Battelle Memorial Institute 


\section{NOTICE}

This report was prepared as an account of work sponsored by the United States Government. Neither the United States nor the Department of Energy, nor any of their employees, nor any of their contractors, subcontractors, or their employees. makes any warranty, express or implied, or assumes any legal liability or responsibility for the accuracy, completeness or usefulness of any information, apparatus. product or process disclosed, or represents that its use would not infringe privately owned rights.

The views, opinions and conclusions contained in this report are those of the contractor and do not necessarily represent those of the United States Government or the United States Department of Energy.

PACIFIC NORTHWEST LABORATORY

operated by

BATTELLE

for the

UNITED STATES DEPARTMENT OF ENERGY

Under Contract DE-AC06-76RLO 1830

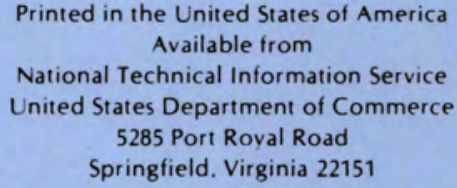

Price: Printed Copy \$

$\therefore$ Microfiche $\$ 3.00$

$\begin{array}{cr}\text { •Pages } & \begin{array}{r}\text { NTIS } \\ \text { Selling Price }\end{array} \\ 001-025 & \$ 4.00 \\ 026-050 & \$ 4.50 \\ 051-075 & \$ 5.25 \\ 076-100 & \$ 6.00 \\ 101-125 & \$ 6.50 \\ 126-150 & \$ 7.25 \\ 151-175 & \$ 8.00 \\ 176-200 & \$ 9.00 \\ 201-225 & \$ 9.25 \\ 226-250 & \$ 9.50 \\ 251-275 & \$ 10.75 \\ 276-300 & \$ 11.00\end{array}$


PNL-3645

UC-94e

33679000561573

BIBLIOGRAPHY OF THE

SEASONAL THERMAL ENERGY

STORAGE LIBRARY

L. S. Prater

G. Casper, Midwest Research Institute

R. A. Kawin, Control Data Corporation

August 1981

Prepared for

the U.S. Department of Energy

Office of Energy Systems Research under Contract DE-AC06-76RL0 1830

Pacific Northwest Laboratory

Richland, Washington 99352 


\section{ACKNOWLEDGMENTS}

This bibliography has been produced through the joint efforts of personnel from the Pacific Northwest Laboratory, Midwest Research Institute, Lawrence Livermore Laboratory, and Control Data Corporation. The authors wish to acknowledge specific contributions made by individuals from these organizations.

Jay R. Eliason of the Pacific Northwest Laboratory provided invaluable guidance during the development of the STES Library and the preparation of this bibliography. The authors also acknowledge Charles H. Lee of Midwest Research Institute, who contributed to the development of the library.

Viktor E. Hampel of Lawrence Livermore Laboratory directed the development of the STES Technology Information System (STES-TIS) and its bibliographic data files, from which the listings in this document were obtained. William G. Rabe of Control Data Corporation is also acknowledged for his contributions to the development of the STES-TIS.

The authors also wish to acknowledge Kay Mills, Teresa A. Zinn, and Tracey B. Webb of the Pacific Northwest Laboratory for their help in the actual preparation of this document. 



\section{CONTENTS}

ACKNOWLEDGMENTS

GUIDELINES FOR USE OF THE BIBLIOGRAPHY vii

INTRODUCTION iX

MAIN LISTING

$\begin{array}{ll}\text { AUTHOR INDEX } & 203\end{array}$

IDENTIF ICATION NUMBER INDEX 255 
The Main Listing is arranged alphabetically by the last name of the first author. Each citation includes the author's name, title, publisher, publication date, and where applicable, the National Technical Information Service (NTIS) number or other document number.

The number preceding each citation is the identification number for that document in the Seasonal Thermal Energy Storage (STES) Library. Occasionally, one or two alphabetic characters are added to the identification number. These alphabetic characters indicate that the document is contained in a collection of papers, such as the proceedings of a conference. Citations for which the STES Library identification number is 9999 represent documents that are presently on order and have not yet been received by the STES Library.

In some cases, the bibliography contains more than one document by the same author. When this occurs, the author's name is given in the first citation but is omitted from succeeding citations. A blank line at the beginning of a citation indicates that the author is the same as the one in the preceding citation and has therefore been omitted.

The Author Index allows the user to find all articles to which a particular author contributed, either as the senior author or as a contributing author. The Author Index contains an alphabetical list of all authors in the bibliography. It contains the names of contributing authors as well as the senior or first authors. Following each author's name are the STES Library identification number(s) for any document(s) written by that author. The user can refer to the Identification Number Index to find out where these citations are located in the Main Listing. The Identification Number Index is arranged numerically by the STES Library identification number. Following each number, the name(s) of the author(s) of that document are given. Using the last name of the senior author, the citation can be located in the Main Listing, which is arranged alphabetically by the last name of the senior author. 
. 


\section{INTRODUCTION}

The Seasonal Thermal Energy Storage (STES) Library has been developed in support of the STES Program, which is managed by the Pacific Northwest Laboratory (PNL) for the U.S. Department of Energy. The objective of the STES Program is to conduct research and development studies required to provided a sound technical base for the implementation of seasonal thermal energy storage concepts.

Seasonal storage of thermal energy has the potential to make a significant near-term contribution towards relief of the national energy shortage. Various forms of surplus energy, including winter chill, summer heat, and industrial waste heat, can be stored until needed, thus reducing the need for generating primary energy and lessening the nation's dependence on imported petroleum fuels. Potential storage media include aquifers (subsurface, water-bearing formations), lakes, ponds, and earth. Storage of thermal energy in aquifers has been chosen for initial development under the STES Program. Other methods of seasonal storage are also being evaluated by studying existing literature and by following current work in other countries.

The STES Library was established in FY 1979 with the objective of assembling and disseminating information about thermal energy storage. The STES Library is intended to support the staff and 
subcontractors of the STES Program, as well as other researchers in the field of energy storage.

The STES Library now contains over 1700 references. Although the library contains articles pertaining to many types of seasonal thermal energy storage, the main emphasis is on the storage of energy in aquifers. The library contains a wide range of key references on topics related to thermal energy storage, including the following:

- STES-related mathematical and computer models

- STES-related demonstrations and experiments

- non-aquifer storage methods

- $\quad$ economic feasibility

- environmental and legal considerations

- aquifer characterization methods

- energy and mass transport in aquifers

- thermal fatigue of aquifer and well materials

- $\quad$ aquifer plugging problems

- well construction amd maintenance

- well-field design and operating criteria

- corrosion, scaling, and encrustation

- reinjection

- wellbore and piping heat losses

- heat transfer equipment

- $\quad$ energy sources

- industrial applications and district heating. 
Since August 1980, Midwest Research Institute (MRI) has been assisting PNL with maintenance and development of the STES Library. Under a subcontract with PNL, MRI has the responsibility of operating and expanding the library. The library must continue to grow in order to keep pace with the Program as it progresses. New references are continually being identified and procured for the library.

Bibliographic information from the STES Library has been entered into the STES Technology Information System (STES-TIS), which is being developed with assistance from Lawrence Livermore Laboratory. The STES-TIS is a comprehensive, computer-based information system which provides the capability to store and manipulate various types of data files, including the bibliographic data file. Each library article is represented by a citation in the bibliographic data file. This data file can be easily updated to include citations for new articles by using an automated, on-line procedure.

The STES-TIS provides the capability to conduct customized, on-line searches of the bibliography. A user may conduct a search on any field of the citation, including author, title, publisher, publication date, keywords, etc. The citations identified as the result of a search can be printed out in a variety of formats. The bibliographic listings contained in this report were obtained by printing out the contents of the bibliographic data file. 

MAIN LISTING 
1710 ACEC Research and Management Foundation.

1979 Well Water Energy Systems for Buildings.

Oak Ridge National Laboratory, Oak Ridge, TN. 6 pp.

1547 Abdel-Wahed, R.M., P.F. Emerson, P.L. Blackshear and M. Riaz.

1979 Effects on thermal storage efficiencies of modifying heat-transport properties of indigenous sandstones. Energy $4(2): 183-192$.

1 Abrams, A.

1977 Mud design to minimize rock impairment due to particle invasion. Journal of Petroleum Technology 29(5):586-592.

2 Ackerman, T.V. and E.J. Lynde.

1944 Effect of storage reservoir detritus on ground water. American Water Works Association Journal 36:315-322.

1657 Acosta-Gonzalez, G. and D.L. Reddell.

1980 Optimal Use of Groundwater and Surface Water to Reduce Land Subsidence.

Texas A\&M University, Texas Water Resources Institute, College Station. 228 pp. TR-103, PB 80-22033 8.

1116 Acurex Corporation, Aerotherm Division.

1976 Application of Solar Energy to the Supply of Industrial Process Hot Water: Energy Reduction and Economic Analysis Report. Acurex Corporation, Aerotherm Division, Mountain View, CA. 119 pp. SAN/ 1218-2.

631 Adachi, T., S. Serata, and S. Sakurai.

1969 Determination of underground stress field based on inelastic properties of rock.

Proceedings, 11th Symposium on Rock Mechanics, University of California, June. 293-328.

972 Adams, D.D., D.A. Darby, and R.J. Young.

1978 Habitat Development Field Investigations: Windmill Point Marsh Development Site, James River, Va. Wright State University, Dayton, $\mathrm{OH}$ and $01 \mathrm{~d}$ Dominion University, Norfolk, VA. Appendix F, Vol. 1. 45 pp. D-77-23.

973

1978 Habitat Development Field Investigations: Windmill Point Marsh Development Site, James River, VA.

Wright State University, Dayton, $\mathrm{OH}$ and 01d Dominion University, Norfolk, VA. Appendix F, Vol. 2. 72 pp. D-77-23.

1340 Adams, M.V.

1973 Report on Water Injectivity Test, Lease OCS-P0241, We11 No. B-49-1, Dos Cuadras Field, Santa Barbara Channel, Off California.

U.S. Geological Survey, Arlington. Circular 687. 28 pp. 
3 Adams, R.H. and A.M. Khan.

1969 Cyclic steam injection project performance analysis and some results of a continuous steam displacement pilot. pp. 273-278 in Thermal Recovery Techniques, Society of Petroleum Engineers of AIME, Dallas.

787 Adkison, J.A.

1976 Programmable controller has its place in production of $0 i 1$. $0 i 1$ and Gas Journal 74(47):131-135.

975 Adolfson, W.F.

1979 Waste Heat As An Alternate Fuel--Its Opportunities and Potential. American Chemical Society, Washington, DC. 1734-1736.

632 Advani, S.H., L.Z. Shuck, H.Y. Chang, and H.V. Gangarao.

1976 Analytical and Experimental Investigations on Induced Fracturing of Reservoir Rock.

American Society of Mechanical Engineers, New York. 9 pp. 76-Pet-8.

788 Advisory Council on Historic Preservation.

1974 Procedures for the Protection of Historic and Cultural Properties: Title 36 - Parks, Forest, and Public Property, Chapter 8-Part 800.

Federal Register Jan24:422-430.

1345 Aerospace Corp., Environment and Conservation Directorate.

1979 Solar Applications Analysis for Energy Storage: Program Plan.

Aerospace Corp., Environment and Conservation Directorate, Germantown, MD. 33 pp. (Draft).

1756 Aguado, E.

1979 Optimization Techniques and Numerical Methods for Aquifer Management.

Ph.D. Thesis, Stanford University, Stanford, CA. 189 pp.

1336 Air Conditioning, Heating and Refrigeration News.

1980 Underground rock layer could store heated water.

Air Conditioning, Heating and Refrigeration News Jan28:26.

176 Air Conditioning, Heating and Ventilating.

1965 Heat pumps: selection and application.

Air Conditioning, Heating and Ventilating 62(10):55-86.

633 Aktan, T. and S.M. Farouq-Ali.

1975 Effect of Cyclic and In Situ Heating on the Absolute Permeabilities, Elastic Constants, and Electrical Resistivities of Rocks.

Society of Petroleum Engineers of AIME, Dallas. 20 pp. SPE-5633. 
1734 A1-Ansari, J.M.

1980 High Temperature Thermal Energy Storage in Aquifers with a Solar Power Plant Application.

Ph.D. Thesis, University of Alabama, University. 190 pp.

1383al Alario, J. and R. Haslett.

1980 Active heat exchange system devalopment for latent heat thermal energy storage.

Thermal Energy Storage: Fourth Annual Review Meeting, Tysons Corner, VA, Dec. 3-4, 1979. 375-384. CONF-791232.

$1544 t$

1980 Active heat exchange: system development for latent heat thermal energy storage.

Proceedings of the DOE Thermal and Chemical Storage Annual Contractors' Review Meeting. 74-76.

4 Alavian, $V$.

1973 Design and Construction of a Research Station for the Study of Induced Vertical Mixing in a Thermally Stratified Pond Using Warm Water Discharge.

M.S. Thesis, University of Wisconsin. 83 pp. PB-237701.

1067 Alexander, F.

1976 Use of heat recovery equipment in the aluminum industry.

Light Metal Age Aug:13-15.

5 Allegrini, G. and G. Benvenuti.

1970 Corrosion characteristics and geothermal power plant protection: collateral processes of abrasion, erosion, and scaling.

U.N. Symposium, Development and Utilization of Geothermal

Resources, in Geothermics 2(1):865-881.

1360a Allen, C.P. and G. Clark.

1979 Structural thermal mass and comfort cooling requirements of commercial buildings in various U.S. climates.

Proceedings of Solar Energy Storage Options, San Antonio, TX, March 19-20. 1:335-338. CONF-790328-P2.

1906 Allen, D.M.

1981 Energy storage for U.S. Air Force ground power sites. Technical and Economic Analysis Meeting, Chicago, April 22.

1158 Al len, R. (ed).

1973 Proceedings of the Solar Heating and Cooling for Buildings Workshop. Washington, DC, March 21-23: Part 1, Technical Sessions.

University of Maryland, Department of Mechanical Engineering, College Park, MD. 226 pp. PB-223 536. 
620 Allen, R.D.

1979 Thermal Energy Storage in Aquifers: An Overview.

Pacific Northwest Laboratory, Battelle, Richland, WA. 61 pp. (Draft).

1160

1979 Thermal Energy Storage in Aquifers: Preliminary Information. Pacific Northwest Laboratory, Battelle, Richland, WA. 73 pp. PNL-3062.

1508 Allen, R.D. and P.J. Gutknecht.

1980 Porous Media Experience Applicable to Field Evaluation for Compressed Air Energy Storage.

Pacific Northwest Laboratory, Battelle, Richland, WA. 81 pp. PNL-3294, UC-94b.

1068 Aller, P., W. Saylor, G. Schmidt, and D. Wein.

1976 Multipurpose insulation system for a radioisotope fueled mini-Brayton heat source assembly.

11th Intersociety Energy Conversion Engineering Conference. $1: 208-215$.

6 Allison, L.E.

1947 Effects of microorganisms on permeability of soil under prolonged submergence.

Soil Science 63:439-450.

1496 Allman, D.W., D. Goldman and W.L. Niemi.

1979 Evaluation of Testing and Reservoir Parameters in Geothermal Wells at Raft River and Boise, Idaho.

EG\&G Idaho, Inc., Idaho Falls. 4 pp.

7 Alpert, J.E., S.C. VanDemark, D.D. Fritton, and D.R. DeWalle.

1976 Soil temperatures and heat loss for a hot water pipe network buried in irrigated soil.

Journal Environmental Quality 5(4):400-405.

1641 Altschuler, S.J.

1978 Heat transfer in conduction limited geothermal wells.

Winter Meeting, American Nuclear Society, Washington, DC. 5 pp.

1978 Geothermal power from salt domes.

13th Intersociety Energy Conversion Engineering Conference, San Diego. $7 \mathrm{pp}$.

1412 Ambo, K.

1979 An Experimental Investigation of Cold and Hot Water Drives in Saturated Porous Media.

Institute of Hydrodynamics and Hydraulic Engineering, Technical

Univ. of Denmark. Series Paper, No. 22. 182 pp. 
Ambrose, E.R.

1974 The heat pump; performance factor, possible improvements. Heating, Piping and Air Conditioning May:77-82.

9

1967 Heat pumps: utilities' viewpoint. Journal of. ASHRAE 9(9):36-37.

1713 American Chemical Society.

1979 Proceedings of the 14th Intersociety Energy Conversion Engineering Conference: Boston, August 5-10. American Chemical Society, Washington. 1:1-1202.

1714

1979 Proceedings of the 14th Intersociety Energy Conversion Engineering Conference: Boston, August 5-10. American Chemical Society, Washington. 2:1203-2078.

789 American Gas Association, Committee on Underground Storage.

1952 The Underground Storage of Gas in the United States and Canada: 28th Annual Report on Statistics. American Gas Association, Committee on Underground Storage. 26 pp.

1343 American Geological Institute.

1980- Geotimes. American Geological Institute, Falls Church, VA.

1482 American Institute of Aeronautics and Astronautics.

1980 Energy to the 21st Century: 15th Intersociety Energy Conversion Engineering Conference, Seattle, WA, August 18-22. American Institute of Aeronautics and Astronautics, Inc., N.Y. $1: 1-874$.

1980 Energy to the 21st Century: 15th Intersociety Energy Conversion Engineering Conference, Seattle, WA, August 18-22. American Institute of Aeronautics and Astronautics, Inc., N.Y. $2: 875-1736$.

1980 Energy to the 21st Century: 15th Intersociety Energy Conversion Engineering Conference, Seattle, WA, August 18-22. American Institute of Aeronautics and Astronautics, Inc., N.Y. $3: 1737-2669$.

1439 American Nuclear Society.

1980 Transactions of the American Nuclear Society. American Nuclear Society, La Grange, IL. Vo1. 34. 899 pp. TANSAO 34 1-899. 
109 American Petroleum Institute, Environmental Affairs Department.

1977 Environmental Research Annual Status Report, February 1977. American Petroleum Institute, Da1las. 4283. 39 pp.

10 American Petroleum Institute.

1975 Environmental Protection Laws and Regulations Related to Exploration, Drilling, Production, and Gas Processing Plant Operations. American Petroleum Institute, Dallas. Bulletin 18.

1952 Recommended Practice for Determining Permeability of Porous Media.

American Petroleum Institute, Division of Production, Dallas. 27 pp. 3rd ed. API RP 27.

790

1978 Subsurface Salt Water Injection and Disposal: Book 3 of Vocational Training Series. American Petroleum Institute, Dallas.

636 American Society of Heating, Refrigerating, and Air-Conditioning Engineers.

1977 ASHRAE Handbook and Product Directory: 1977-Fundamentals. American Society of Heating, Refrigerating, and Air-Conditioning Engineers, New York.

637 American Society of Heating, Refrigerating, and Air-Conditioning Engineers.

1978 ASHRAE Handbook and Product Directory: 1978-Applications. American Society of Heating, Refrigerating, and Air-Conditioning Engineers, New York.

638 American Society of Heating, Refrigerating, and Air-Conditioning Engineers.

1979 ASHRAE Handbook and Product Directory: 1979-Equipment. American Society of Heating, Refrigerating, and Air-Conditioning Engineers, New York.

703 American Society of Heating, Refrigerating, and Air-Conditioning Engineers .

1976 ASHRAE Handbook and Product Directory: 1976-Systems. American Society of Heating, Refrigerating, and Air-Conditioning Engineers, New York.

1804 Anderson, C.A.

1980 Finite Element Modeling of Long-Term Fluid-Structure Interaction Problems in Geologic Media. Los Alamos Scientific Laboratory, Los Alamos, NM. 8 pp. LA-UR-79-3016. 
1282 Anderson, C.J.

1979 The Lawrence Livermore Laboratory Energy Policy Model: A Brief Overview.

Lawrence Livermore Laboratory, Livermore, CA. 9 pp. UCRL -52672.

11 Anderson, J.H.

1972 Economic Power from Geothermal Heat.

J. Hilbert Anderson/Consulting Engineer. $10 \mathrm{pp}$.

12 Anderson, K. and J.E. Kelly.

1976 Exploration for Groundwater in the Madison Limestone, Niobrara County, Wyoming.

28th Annual Field Conference - Wyoming Geological Assoc.

Guidebook. CONF-7609159. 277-281.

1750 Anderson, M.P.

1979 Using models to simulate the movement of contaminants through groundwater flow systems.

CRC Critical Reviews in Environmental Control 9(2):97-156.

976 Anderson, P.A. and E.C. Hallanger.

1979 Community Level Energy Management Systems.

American Chemical Society, Washington, DC. 1737-1740.

13 Andrews, C.B.

1978 The Impact of the use of heat pumps on ground-water temperatures. Ground Water 16(6):437-443.

601

1976 An Analysis of the Impact of a Coal Fired Power Plant on the Groundwater Supply of a Wetland in Central Wisconsin.

M.S. Thesis, University of Wisconsin, Madison. $81 \mathrm{pp}$.

14 Andrews, C.B. and M.P. Anderson.

1978 Impact of a power plant on the ground-water system of a wet 1 and. Ground Water 16(2):105-111.

1979 Thermal alteration of groundwater caused by seepage from a cooling lake.

Water Resource Research 15(3):595-602.

1401- Angerman, T.W.

1969 Deep-we11 disposal a new field for oil and gas techniques. pp. 169-174 in Drilling Production and Practice, American Petroleum Institute.

1633 Anuskiewicz, T. and R. Meador.

1980 Backgrounder and summary. North Central States Conference on District Heating, Detroit, MI, May 29-30. 16 pp. 
243 Aparisi, R.R. and D.I. Teplyakov.

1977 Utilization of solar radiation at large solar plants with pumped storage. Geliotekhnika 13(1):3-10.

17 Appe1, C.A., and J.D. Bredehoeft.

1976 Status of Ground-Water Modeling in the U.S. Geological Survey. U.S. Geological Survey, Arlington. 9 pp. Circular 737.

93 Aquilian, C.

1942 Studio di una Presunta corrente verticale ascendente di acqua iuvenile, [Study of the hypothetical vertically ascending current of juvenile water].

Riv. Geom. Geol. Gecf. Appl. 3(2):19-32.

242 Archie, G.E.

1942 The Electrical resistivity $\log$ as an aid in determining some reservoir characteristics. Transactions, AIME 146:54-62.

1315 Argonne National Laboratory, Oak Ridge National Laboratory and Trinity University.

1979 Proceedings of Solar Energy Storage Options, San Antonio, TX. March 19-20.

Argonne National Laboratory, Oak Ridge National Laboratory and Trinity University. 1:1-333. CONF-790328-P1.

1360

1979 Proceedings of Solar Energy Storage Options, March 19-20, 1979, San Antonio, TX.

Argonne National Laboratory, Oak Ridge National Laboratory and Trinity University. 1:335-629. CONF-790328-P2.

1979 Proceedings of Solar Energy Storage Options, March 19-20, 1979,. San Antonio, TX.

Argonne National Laboratory, Oak Ridge National Laboratory and Trinity University. 2:1-153. CONF-790328-P3.

977 Armstrong, T.B.

1978 Wire mesh flood heating systems. IEEE Transactions: Industry Applications. 1A-14(6):4987-505.

1404 Arosio, S., M. Silvestri, G. Sotgia and A. Muzzio.

1975 A Thermogravimetric pilot plant for the production of mechanical energy from low enthalpy sources.

Proceedings of the Second U.N. Symposium on the Development and Use of Geothermal Resources. 1915-1924. 
18 Aruna, M., N. Arihara, and H.J. Ramey, Jr.

1977 The Effect of temperature and stress on the absolute permeability of sandstones and limestones.

ANS Topical Meetings: Energy and Mineral Resources Recovery, Apri1 12-14. CONF-770440. 541-550.

792 Asbury, J.G., C. Maslowski, and R.0. Mueller.

1979 Solar Availability for Winter Space Heating: An Analysis of the Calendar Period 1953-1975.

Argonne National Laboratory, Argonne, IL. 16 pp. ANL/SPG-14.

1905 Asbury, J.G., J.M. Calm and R.F. Giese.

1981 Assessment of cool storage technologies.

Technical and Economic Analysis Meeting, Chicago, April 22.

791 Asbury, J.G., R.F. Giese, R.0. Mueller and S.H. Nelson.

1977 Commercial feasibility of thermal storage in buildings for utility load leveling.

Proceedings of American Power Conference. 39:794-803.

241 Asbury, J.G., R.F. Giese and R.0. Mueller.

1979 Residential Electric Heating and Cooling: Total Cost of Service. Electrical Power Research Institute, Tampa, FL. 16 pp.

1117 Asbury, J.G. and A. Kouvalis.

1976 Electric Storage Heating: The Experience in England and Wales and in the Federal Republic of Germany.

Argonne National Laboratory, Argonne, IL. 29 pp. ANL/ES-50.

1383af Asbury, J.G. and H.N. Hersh.

1980 Experimental evaluation of thermal energy storage.

Thermal Energy Storage: Fourth Annual Review Meeting, Tysons

. Corner, VA, Dec. 3-4, 1979. 307-314. CONF-791232.

1830 Asselman, G.A.A.

1976 Thermal energy storage unit based on lithium fluoride. Energy Conversion 16:35-47.

978 Auer, W.W. and W.R. Cherry.

1976 ERDA Solar Thermal Energy Program for Industrial Process Heat. U.S. Energy Research and Development Administration, Div. of Solar Energy, Washington. 176-185.

1421 Austin, A.L.

1975 Prospects for advances in energy conversion technologies for geothermal energy development.

Proceedings of the Second U.N. Symposium on the Development and Use of Geothermal Resources. 1925-1935.

1348 Avdonin, N.A.

1964 Some formulas for calculating the temperature field of a formation during thermal injection. 
Neft i Gaz 7(3):37-41. A.T.S.

19 Axtmann, R.C.

1975 Chemical aspects of the environmental impact of geothermal power. Proceedings of the Second U.N. Symposium on the Development and Use of Geothermal Resources. 1323-1327.

1448 Aydelotte, S.R.

1980 Transient We11 Testing in Two-Phase Geothermal Reservoirs. Intercomp, Resource Development and Engineering, Inc. 139 pp. LBL -10562 .

1118 Ayerbe, A., C. Giddey, and B. Maslowski.

1975 Energy in Food and Kindred Products: Physico-Chemical and Technological Approaches.

Battelle-Geneva Research Center. Geneva, Switzerland.

20 Aziz, K., S.A. Bories, and M.A. Combarnous.

1973 The Influence of natural convection in gas, $0 i 1$ and water reservoirs. Journal of Canadian Petroleum Technology 12:41-47.

635 Aziz, K., T. Kaneko, and M.F. Mohtadi.

1972 Seventeen-b natural convection in confined porous media. PACHEC 72, Session 17, Transport Phenomena. 283-284.

734 B\&A Engineers, LTD.

1978 An Assessment of the Technoeconomic Feasibility of Seasonal Thermal Energy Storage Systems. Argonne National Laboratory, Energy and Environmental Systems Division, Argonne, IL. 48 pp. ANL/EES-TM-35.

21 Bachmat, Y., B. Andrews, D. Holtz, and S. Sebastian.

1978 Utilization of Numerical Groundwater Models for Water Resource Management.

Robert S. Kerr Environmental Research Laboratory. 177 pp. PB-2857.

1758 Bachmat, Y., J. Bredehoeft, B. Andrews, D. Holtz and S.

Sebastian.

1980 Groundwater Management: the Use of Numerical Models. American Geophysical Union, Washington. 127 pp.

1356 Bahadur, S.

1979 Tennessee Valley Authority Low Temperature Thermal Energy Storage Technical Feasibility Report.

Acres American Incorp.

240 Baier, D.C. and G.M. Wesner.

1971 Reclaimed wastewater for groundwater recharge. Water Resources Bulletin 7(5):991-1001. 
639 Bailey, J.A., J.C. Mulligan, C.K. Liao, and S.I. Guceri.

1975 Research on Solar Energy Subsystems Utilizing the Latent Heat of Phase Change of Paraffin Hydrocarbons for the Heating and Cooling of Buildings.

North Carolina State University, Raleigh, NC. 64 pp. PB-244 872.

640 Bailey, R.G. (compiler).

1978 Descriptions of the Ecoregions of the United States. U.S. Department of Agriculture, Forest Service, Ogden UT. 77 pp. map.

979 Bak, D.J.

1979 Salt-filled tank supplies heat for high-pressure steam. Design News Apr23:124-125.

1161 Baker, E.T., Jr. and J.R. Wall.

1976 Summary Appraisals of the Nation's Ground-Water Resources: TexasGulf Region.

U.S. Geological Survey, Arlington. 29 pp. Professional Paper $813-\mathrm{F}$.

1707 Baker, P.E.

1969 An Experimental study of heat flow in steam flooding. Society of Petroleum Engineers Journal Mar:89-99.

22 Bakhmeteff, B.A. and N.V. Feodoroff.

1937 Flow through granular media. Journal of Applied Mechanics 4:A96-A103 and 5:A86-A90.

23 Balashov, L.S.

1975 Rare elements in thermal ground water.

Proceedings of the Second U.N. Symposium on the Development and Use of Geothermal Resources. 2187-2195.

24 Balke, K.D.

1977 Das grundwasser als energietrager.

Brennst.-Warme- Kraft 29(5):191-194.

25 Banks, H.O.

1952 Utilization of underground storage reservoirs. Transactions, American Society of Civil Engineers. 118:220-234.

$641^{\circ}$ Barbish, A.B. and G.H.F. Gardner.

1969 The Effect of Heat on Some Mechanical Properties of Igneous Rocks.

Society of Petroleum Engineers of AIME, Dallas. 8 pp. SPE-2395.

26 Barnes, B.A. and P. Livingston.

1947 Value of the electrical log for estimating ground-water supplies and the quality of the ground water.

Transactions, American Geophysical Union 28(6):903-911. 
1715 Barnes, P.R. and H.G. Shapira.

1980 Passive Solar Heating and Natural Cooling of an Earth-Integrated Design.

Oak Ridge National Laboratory, Oak Ridge, TN. 6 pp. CONF-800449--1.

642 Bass-Becking, L.G.M., I.R. Kaplan and D. Moore.

1960 Limits of the natural environment in terms of $\mathrm{pH}$ and oxidation-reduction potentials. Journal of Geology 68(3):243-284.

1831 Bathelt, A.G., R. Viskanta and W. Leidenfrost.

1978 Heat transfer from cylinders during melting of a thermal energy storage material. Heat Transfer 1978, Toronto, Canada. 4:179-184.

259 Bathen, K.H.

1971 Heat storage and advection in the North Pacific Ocean. Journal of Geophysical Research 76(3):676-687.

1156 Battelle Columbus Laboratories and Honeywell.

1977 Survey of the Applications of Solar Thermal Energy Systems to Industrial Process Heat.

Battelle Columbus Laboratories, Columbus, $\mathrm{OH}$ and Honeywe11, Minneapolis. $246 \mathrm{pp}$. Vol. 3.

1120 Battelle Memorial Institute.

1966 Final Technical Report on Thermal Energy Storage. Battelle Memorial Institute, Columbus, OH. NASA-CR-80058.

793 Baylin, F.

1979 Low Temperature Thermal Energy Storage: A State-of-the-Art Survey.

Solar Energy Research Institute, Golden, C0. 107 pp. SERI/RR $-54-164$.

1520 Baylin, F. and M. Merino.

1980 A Survey of Sensible and Latent Heat Thermal Energy Storage Projects. Solar Energy Research Institute, Golden, C0. 303 pp. SERI /RR -335-456.

1521 Baylin, F. and S. Sillman.

1980 Systems Analysis Techniques for Annual Cycle Thermal Energy Storage Solar Systems.

Solar Energy Research Institute, Golden, CO. 32 pp. SER I /RR-721-676 UC-59c.

1279 Bear, J.

1972 Dynamics of Fluids in Porous Media. American Elsevier Publishing Co., Inc., New York. 360 pp. Part 1. 
1280 Bear, J.

1972 Dynamics of Fluids in Porous Media.

American Elsevier Publishing Co., Inc., New York. 360 pp. Part 2.

1523

1979 Hydraulics of Groundwater.

MCGraw-Hi11 International Book Company, New York. 567 pp. ISBN $0-07-004170-9$.

1315k Beard, J.T. and L.U. Lilleleht and F.A. Iachetta.

1979 Evaluation of a system for annual collection and storage of solar energy.

Proceedings of Solar Energy Storage Options, San Antonio, TX.

March 19-20. 1:127-136. CONF-790328-P1.

981 Beatson, C.

1974 Integrating high temperature reactors in a chemical works. The Engineer 239(6196):36-37.

$1177 p$ Beaulaurier, L.0.

1978 Field test of geothermal/hydrocarbon shell-and-tube heat exchanger.

Pages 50-51 in Earth Science Division Annual Report, Lawrence Berkeley Laboratory, Berkeley, CA. LBL-8648.

27 Beck, J.L.

1972 Convection in a box of porous material saturated with fluid. The Physics of Fluids 15(8):1377-1383.

1385 Bedinger, M.S. and R.T. Sniegocki.

1976 Summary Appraisals of the Nation's Ground-water Resources: Arkansas-White-Red Region. U.S. Geological Survey, Arlington. Professional Paper 813-H. 31 pp.

28 Beers, T.S.

1967 Heat pumps: consultant's viewpoint. Journal of ASHRAE $9(9): 42-44$.

1548 Behnia, M., and R. Viskanta.

1979 Free convection in thermally stratified water cooled from above. Journal of Heat and Mass Transfer 22(4):611-623.

258 Behnke, J.J.

1969 Clogging in surface spreading operations for artificial ground-water recharge. Water Resources Research 5(4):870-876.

643 Bel1, J.S. and J.M. Shepherd.

1951 Pressure behavior in the Woodbine Sand. Petroleum Transactions, AIME 192:19-28. 
644 Bennion, D.W. and M.J. Goss.

1977 A Sinusoidal pressure response method for determining the properties of a porous medium and its in-situ fluid. Canadian Journal of Chemical Engineering 55:113-117.

1177 ab Benson, S.M., C.B. Goranson, J. Haney, D.G. McEdwards, T.N. Narasimhan and R.C. Schroeder.

1978 Summary of well tests and analyses for the East Mesa geothermal site.

Pages 86-93 in Earth Science Division Annual Report, Lawrence Berkeley Laboratory, Berkeley, CA. LBL-8648.

29 Benson, S.M., C.B. Goranson, J.P. Haney, and R.C. Schroeder.

1979 The Status of the Resource Evaluation at Susanville, California. Lawrence Berkerley Laboratory, Berkeley. LBL-9469. 4 pp.

1177 aa Benson, S.M., C.B. Goranson and R.C. Schroeder.

1978 Well test data analysis methods at LBL.

Pages 79-85 in Earth Science Division Annual Report, Lawrence Berkeley Laboratory, Berkeley, CA. LBL-8648.

761 Bentall, R. (ed).

1971 Methods of determining permeability, transmissibility, and drawdown.

pp. 243-341 in Ground Water Hydraulics.

1599 Bentley, C.B.

1979 Aquifer coefficients determined from multiple well effects, Fernandina Beach, Florida. Ground Water 17(6):525-531.

958 Berend, J.E.

1971 Clogging processes and optimization of basin recharge. Artificial Ground Water Recharge Conf. Sept. 1970, England Water Research Association. 1:111-128, Paper No. 5.

1615 Bergqvist, B. and J.G. Holmberg.

1978 Swedish Solar Energy Projects 1978. Swedish Council for Building Research, Stockholm. 160 pp. PB-290 376 .

794 Berkowitz, J.B. and H.P. Silverman (eds).

1976 Proceedings of the Symposium on Energy Storage, 148th Meeting of the Electrochemical Society.

Electrochemical Society, Princeton, NJ. 258 pp.

30 Bernard, W.J.

1978 Deep, geopressured aquifers: a new energy source?

Petroleum Engineer International 50(3):84-90. 
1572 Berntsson, T., P.A. Franck, L. Jacobson, B. Modin, and P. Wilen.

1980 The Use of the Ground as a Heat Source for Heat Pumps in Urban Areas: An Overall Review of Technical-Economic Aspects.

Swedish Council for Building Research, Stockholm, Sweden. 47 pp. D39:1980.

1792 Bertoldi, G.L.

1979 A Plan to Study the Aquifer System of the Central Valley of California.

U.S. Geological Survey, Arlington. $48 \mathrm{pp}$. Open-File Report $79-1480$.

257 Besant, R.W. and C.B. Winn.

1976 Cost effective solar heating of houses with seasonal storage of energy.

International Solar Energy Society, American Section, 4:409-424.

1441 Beshore, D.G., D.G. Raynor and M.G. Barth.

1979 Storage Fluid Maintenance Study Using Caloria HT-43 Hydrocarbon 0i1: Final Report.

Martin Marietta Aerospace, Denver. 272 pp.

982 Beverly, W.D., M. Rubeck, G.L. Vieth, and P.J. Hurley.

1978 Applications of thermal energy storage in the paper and pulp industry.

Journal Energy 2(6):375-380.

983 Beverly, W.D., W.W. Engle, and F.0. Mahony.

1977 Integration of high temperature thermal energy storage into a Solar Thermal Brayton Cycle Power Plant. 12th Intersociety Energy Conversion Engineering Conference. $2: 1195-2002$.

255 Bezdek, R.H., A.S. Hirshberg, and W.H. Babcock.

1979 Economic feasibility of solar water and space heating. Science 203:1214-1220.

1731 Bilgen, E.

1980 Solar Utility Total Energy System: SUTES. Exregy Research Corporation, Montreal. 42 pp.

1544v Birchena11, C.E.

1980 Heat storage in alloy transformations. Proceedings of the DOE Thermal and Chemical Storage Annual Contractors' Review Meeting. 81-81g.

31 Birtles, A.B. and M.J. Reeves.

1977 A Simple effective method for the computer simulation of groundwater storage and its application in the design of water resource systems. Journal of Hydrology 34(12):77-96. 
256 Birtles, A.B. and M.J. Reeves.

1977 Computer modeling of regional groundwater systems in the confined-unconfined flow regime. Journal of Hydrology $34(1 / 2): 97-127$.

1864 Bishop, H.K. and J.R. Bricarello.

1976 Scaling and Corrosion in an Experimental Geothermal Power Plant. Society of Petroleum Engineers of AIME, Dallas, TX. SPE 6612. 4 $\mathrm{pp}$.

1390 Bishop, T.N., R.A. Walter, and J.B. Martin.

1978 Environmental, Safety and Health Standard Identification for Geothermal Energy: Report 4 - Subsidence and Induced Seismicity. Pacific Northwest Laboratory, Battelle, Richland, WA. 16 pp. PNL-2583-4.

984 Bjerklie, J.W. and M.B. Mc Neil.

1979 Fuel Conservation in High Temperature Slot-Forge Furnaces. American Chemical Society, Washington, DC. 1647-1652.

1482x Black, R.A.

1980 The Federal Geothermal Energy Program. Energy to the 21st Century: 15th Intersociety Energy Conversion Engineering Conference, Seattle, WA, August 18-22. 1:151-161.

1634 Black and Veatch Consulting Engineers.

1980 Evaluation of Cogeneration Alternatives.

Black and Veatch Consulting Engineers, Kansas City, M0. 46 pp.

762 Blackshear, P.L., P.L. Emerson, B. Rabi-Baliga and M. Riaz.

1977 Gravel-filled trenches in earth for annual thermal energy storage.

Proceedings of the Annual Meeting, American Section of the International Solar Energy Society. 16-16 to 16-19.

33 Blackwe11, D.D., E. Granados, and J.B. Koenig.

1977 Heat flow and geothermal gradient exploration of geothermal areas in the Cordillera de Guanacaste of Costa Rica. Geothermal Resources Council, Transactions 1:17-18.

1582r Blahnik, D.E.

1980 Non-aquifer seasonal thermal energy storage concepts. Mechanical, Magnetic, and Underground Energy Storage 1980 Annual Contractors' Review. pp. 117-122. CONF-801128.

1980 Preliminary Survey and Evaluation of Nonaquifer Thermal Energy Storage Concepts for Seasonal Storage.

Pacific Northwest Laboratory, Battelle, Richland, WA. PNL-3625. 
32 Blake, T.R. and S.K. Garg.

1976 On the species transport equation for flow in porous media. Water Resources Research 12(4):748-750.

34 Bl akeley, L.E.

1945 The Rehabilitation, cleaning, and sterilization of water wells. American Water Works Association Journal 37:101-114.

1162 Blatz, E.H., S.W. West, and S.R. Ash.

1962 Potential yield of deep water wells in the southern part of the Jicarilla Apache Indian Reservation and Vicinity, San Juan Basin, New Mexico.

Paper 450-D, pp. 173-175 in U.S.G.S. Research, Short Papers in Geology, Hydrology, and Topography, Articles 120-179, U.S.G.S.

1377 Bleakley, W.B.

1966 Steamed wells need good completions.

$0 i 1$ and Gas Journal 64(11):138A-1380.

883 Blevins, T.R. and R.H. Billingsley.

1975 The Ten-pattern steamflood, Kern River Field, CA. Journal of Petroleum Technology 27:1505-1514.

1611 Bligh, T.P.

1977 Thermal energy storage in Targe underground systems and buildings.

Rockstore 77, Storage in Excavated Rock Caverns, 1st International Symposium, Stockholm, September 5-8. 1:63-71.

1887 Block, D.A. and L. Hodges.

1979 Portable Phase Change Storage for a Direct Gain Passive Residence.

Iowa State University of Science and Technology, Ames and Engineering Research Institute, Ames Laboratory. 6 pp. IS-M-193. (Microfiche).

1879 Blomquist, C.A.

1979 HYCSOS: Chemical Heat Pump and Energy Conversion Systems Based on Metal Hydrides: Mid-Year Program Report.

Argonne National Laboratory, Argonne, IL. 34 pp. ANL/EES-TM-50. (Microfiche).

1524 BToomster, C.H., B.A. Garrett-Price and L.L. Fassbender.

1980 Residential Heating Costs: A Comparison of Geothermal, Solar and Conventional Resources.

Pacific Northwest Laboratory, Battelle, Richland, WA. 173 pp. PNL-3200, UC-66i.

35 Bloomster, C.H., L.L. Fassbender, and C.L. McDonald.

1977 Geothermal Energy Potential for District and Process Heating Applications in the U.S.: An Economic Analysis. Battelle Northwest Laboratories, Richland, WA. BNWL-2311. $45 \mathrm{pp}$. 
254 Bloss, S. and V. Grigul 1.

1976 Energy storage and temperature distribution in lakes.

International Seminar on Future Energy Production Heat and Mass Transfer Problems. 2:801-811.

1163 Bloyd, R.M., Jr.

1974 Summary Appraisals of the Nation's Ground-Water Resources: Ohio Region.

U.S. Geological Survey, Arlington. 41 pp. Professional Paper 813-A.

1164

1975 Summary Appraisals of the Nation's Ground-Water Resources: Upper Mississippi Region. U.S. Geological Survey, Arlington. 22 pp. Professional Paper $813-\mathrm{B}$.

645 Boberg, T.C. and R.B. Lantz.

1966 Calculation of the production rate of a thermally stimulated well.

Journal of Petroleum Technology 18:1613-1623.

36 Bodvarsson, G.

1977 Unconfined aquifer flow with a linearized free surface condition. Jokul1 $27: 84-87$.

1961 Physical characteristics of natural heat resources in Iceland. New Sources of Energy, Proceedings of U.N. Conference, Rome, Italy, Aug. 21-31. 2:82-90.

1969 On the temperature of water flowing through fractures. Journal of Geophysical Research 74(8):1987-1992.

1971 Approximation methods for equivalent strata. Journal of Geophysical Research 76(17):3932-3989.

1973 Downward continuation of constrained potential fields. Journal of Geophysical Research 78(8):1288-1292.

1974 Geothermal resource energetics. Geothermics 3(3):83-92.

1976 Thermoelastic phenomena in geothermal systems. Proceedings of the Second U.N. Symposium on the Development and Use of Geothermal Resources. 2:903-907. 
43 Bodvarsson, $G$.

1977 A Secondary Recovery Method for the Extraction of Geothermal

Energy.

U.S. Energy Research and Development Administration, Washington.

$81 \mathrm{pp}$. RL0-2227-T21-1.

247

1972 The Exergy of thermal water.

Geothermics 1(3):93-95.

248

1961 Utilization of geothermal energy for heating purposes and combined schemes involving power generation and/or by-products. Joku11 11:429-434.

1972 Thermal problems in the siting of reinjection wells. Geothermics 1(2):63-66.

1978 Hydroelastic oscillations in fractured systems. Hot Dry Rock Geothermal Workshop, Los Alamos Scientific Laboratory, Apri1 20-28. (Abstract).

1978 Energy currents in fractured geothermal systems. Hot Dry Rock Geothermal Workshop, Los Alamos Scientific Laboratory, Apri1 20-28. (Abstract).

1970 Confined fluids as strain meters. Journal of Geophysical Research 75(14):2711-2718.

646

1973 Remarks on generalized solutions of improperly posed problems in the exploration sciences. Joku11 23:37-44.

647

Some considerations on the optimum production and use of geothermal energy.

Jokul1 (?):199-206.

648

1970 A Surface integral in potential theory. Geophysics 35(3):501-503.

649

1973 Temperature inversions in geothermal systems. Geoexploration 11:141-149. 
1165 Bodvarsson, G.

1950 Geophysical methods in the prospecting for hot water in Iceland. Journal Engineering Association 35:49-59. [in Icelandic].

1950 Computation of elastic vibrations by means of integral equations. Journal Engineering Association 35:61-64. [in Icelandic].

1954 Terrestrial heat balance in Iceland.

Journal Engineering Association 29:69-76. [in Icelandic].

1975 Fracture flow in geothermal reservoirs. Workshop on Geothermal Reservoir Engineering, Stanford, CA. 45-49.

1977 Interpretation of borehole tides and other elastomechanical oscillatory phenomena in geothermal systems.

Workshop on Geothermal Reservoir Engineering, Stanford, CA. 203-208.

1978 Pressure field propagation and density currents. Second Invitational Well Testing Symposium, Lawrence Berkeley Laboratory. 59.

884 Bodvarsson, G., R.W. Couch, W.T. MacFarlane, R.W. Tank, and R.M. Whitsett.

1974 Telluric current exploration for geothermal anomalies in Oregon. The Oregon Bin 36(6):93-106.

1717 Bodvarsson, G.S. and C.F. Tsang.

1980 Injection into a Fractured Geothermal Reservoir.

Lawrence Berkeley Laboratory, Berkeley, CA. 4 pp. LBL-10983.

44 Bodvarsson, G. and A. Bjornsson.

1976 Hydroelastic cavity resonators. Jokull 26:20-24.

45 Bodvarsson, G. and G.M. Reistad.

1975 Econometric analysis of forced geoheat recovery for low-temperature uses in the Pacific Northwest.

Proceedings of the Second U.N. Symposium on the Development and Use of Geothermal Resources. 3:1559-1564.

1170 Bodvarsson, G. and J.M. Hanson.

1976 Forced geoheat extraction from sheet-like fluid conductors. Second Workshop on Geothermal Reservoir Engineering. 52-60. 
1256 Bodvarsson, G. and J.M. Hanson.

1977 A Secondary Recovery Method for the Extraction of Geothermal Energy: Final Report. Oregon State University, Corvallis. 217 pp. RL0-2227-T21-3.

245 Bodvarsson, G. and J. Zoega.

1961 Production and distribution of natural heat for domestic and industrial heating in Iceland. Jokul $11: 48-55$.

246 Bodvarsson, G. and R.P. Lowell.

1972 Ocean-floor heat flow and the circulation of interstitial waters. Journal of Geophysical Research 77(23):4472-4475.

1113 Boeing Engineering and Construction.

1977 Advanced Thermal Energy Storage Concept Definition for Solar Brayton Power Plants: Vol. 1 Final Technical Report. Boeing Engineering and Construction, Seattle. SAN/1300-1.

602 Boersma, L., L.R. Davis, G.M. Reistad, J.C. Ringle, and W.E. Schmisseur.

1974 A System Analysis of the Economic Utilization of Warm Water Discharge from Power Generating Stations. Oregon State University, Engineering Experimental Station, Corvallis. 257 pp. Bulletin No. 48.

46 Boldizsar, T.

1970 Geothermal energy production from porous sediments in Hungary. U.N. Symposium, Development and Utilization of Geothermal Resources, in Geothermics 2(1):99-109.

47 Bolton, P.

1961 Prevention of water source contamination. American Water Works Association Journal 53(10):1243-1250.

985 Bonisteel, W.D. and J. Martinovic.

1979 Heat reclaim at mine surface plants. Canadian Mining and Metallurgical Bulletin 72(801):129-133.

1706 Bories, S.A. and Combarnous, M.A.

1973 Natural convection in a sloping porous layer. Journal of Fluid Mechanics $57(1): 63-79$.

1477 Borst, W.L. and J.L. Kretsch.

1978 Long-term Storage of Environmental Thermal Energy. Southern Illinois University, Department of Physics and Astronomy, Carbondale, IL. 7 pp.

48 Bosazza, V.L.

1952 On the storage of water in rocks in situ. Transactions, American Geophysical Union 33(1):42-48. 
1315t Bose, J.E. and C.W. Ledbetter and J.R. Partin.

1979 Earth coils and geothermal wells used as solar energy storage devices.

Proceedings of Solar Energy Storage Options, San Antonio, TX. March 19-20. 1:211-220. CONF-790328-P1.

9999eb Bose, T.E., C.W. Ledbetter, and J.R. Partin.

1979 Earth coils and geothermal wells used as solar energy devices. Sun 2: Proceedings of the International Solar Energy Society Silver Jubilee Congress, Atlanta, GA, May 1979. 1:797-801.

1832 Boser, 0.

1977 Safety considerations for high temperature thermal energy storage in fluoride salts.

Proceedings of the 12th Intersociety Energy Conversion

Engineering Conference. 2:575-582.

252 Bostock, C.A.

1975 Minimizing Costs in Well Field Design in Relation to Aquifer Models.

Ph.D. Thesis. University of Arizona. University Microfilms, Ann Arbor, MI.

49 Bostock, C.A., E.S. Simpson, and T.G. Roefs.

1977 Minimizing costs in well field design in relation to aquifer models.

Water Resources Research 13(2):420-426.

1833 Botham, R.A., G.H. Jenkins, G.L. Ball and I.0. Salyer.

1978 Crosslinked HDPE makes the grade in thermal energy storage. Modern Plastics Dec:54-56.

1871 Botham, R.A., G.L. Bal1.

1978 Form-Stable Crystalline Polymer Pellets for Thermal Energy Storage: High Density.

Monsanto Research Corporation, Dayton, $\mathrm{OH} .84$ pp. ORNL/SUB-7398/4. (Microfiche).

1803 Bourdeau, L.E.

1980 Study of Two Passive Solar Systems Containing Phase Change Materials for Thermal Storage.

Los Alamos Scientific Laboratory, Los Alamos, NM. 6 pp. LA-UR-80-1669.

50 Bouwer, $\mathrm{H}$.

1977 Land subsidence and cracking due to ground-water depletion. Ground Water 15(5):358-364.

1979 Geothermal power production with irrigation waste water. Ground Water $17(4): 375-384$. 
795 Bouwer, H.

1968 Returning wastes to the 1 and: a new role for agriculture. Journal of Soil and Water Conservation 23(5):164-168.

953

Water Quality Aspects of Intermittent Systems Using Secondary Sewage Effluent. U.S. Water Conservation Laboratory, Phoenix, AZ. Paper 8. $199-217$.

1255

1979 Wastewater reuse alternatives.

Symposium on Water Conservation Alternatives for

Groundwater and Surface Water Utilization, Phoenix, AZ. 15 pp.

1254 Bouwer, H., R.C. Rice, J.C. Lance and R.G. Gilbert.

1979 Renovation of sewage effluent with rapid-infiltration land treatment systems.

Proceedings, Symposium on Wastewater Reuse for Groundwater

Recharge, CA. Polytechnic UnIv., Pomona, September 2-7. 30 pp.

650 Bowen, R.G., D.D. Blackwell, and D.A. Hul1.

1977 Geothermal Exploration Studies in Oregon.

State of Oregon, Department of Geology and Mineral Industries, Portland.50 pp. Map. Paper no. 19.

651 Bowser, M.L. and W.E. Thomas.

1976 Bureau of Mines Portable Recording Methanometer.

U.S. Department of Interior, Bureau of Mines. 6 pp. Report Investigation 7270 .

52 Brace, W.F., A.S. Orange, and T.R. Madden.

1965 The Effect of pressure on the electrical resistivity of water-saturated crystalline rocks. Journal of Geophysical Research 70(22):5669-5678.

1238 Bramlette, T.T.

1979 Thermochemical Energy Storage and Transport Program Progress Report, October 1977 - December 1978.

Sandia Laboratories, Albuquerque, NM. 109 pp. SAND/79-8208.

1895 Bramlette, T.T. and R.W. Mar.

1978 FY 1978 Annual Operating Plan for the Thermochemical Energy Storage and Transport (TEST) Program.

Sandia Laboratory, Livermore, CA. 76 pp. SAND-77-8288. (Microfiche).

$1582 \mathrm{ab}$ Brandshaug, T. and A.F. Fossum.

1980 Numerical studies of CAES caverns in hard rock.

Mechanical, Magnetic, and Underground Energy Storage 1980 Annual

Contractors' Review. pp. 206-212. CONF-801128. 
796 Brashear, J.P. and V.A. Kuuskraa.

1978 The potential and economics of enhanced oil recovery. Journal of Petroleum Technology 30:1231-1239.

53 Brashears, M.L.

1941 Ground-water temperature on Long Island, New York, as affected by recharge of warm water.

Economic Geology 36:811-828.

54 Braunlich, F.H.

1975 Well completion: techniques and methods. pp 73-100 in Environmental Aspects of Chemical Use in We 11 Drilling Operations, U.S. EPA. EPA-560/1-75-004.

970 Braunstein, J. (ed).

1973 Underground Waste Management and Artificial Recharge. Assoc. of Petroleum Geologists, U.S. Geological Survey and International Assoc. of Hydrological Sciences. 1:1-663.

971

1973 Underground Waste Management and Artificial Recharge. Assoc. of Petroleum Geologists, U.S. Geological Survey and International Assoc. of Hydrological Sciences. 2:667-931.

652 Bredehoeft, J.D.

1967 Response of well-aquifer systems to earth tides. Journal of Geophysical Research 72(12):3075-3087.

55 Briggs, J.B. and C.J. Shaffer.

1977 Seasonal Heat Pump Performance for a Typical Northern United States Environment.

E.G. and G. Idaho, Inc. 81 pp. Tree-1181.

1171 Briggs, J.E.

1963 Countercurrent Gravity Segregation in Porous Media. PhD. Thesis, University of Michigan. University Microfilms International, Ann Arbor, MI. $132 \mathrm{pp}$.

653 Briggs, J.E. and D.L. Katz.

1966 Drainage of Water from Sand in Developing Aquifer Storage. Society of Petroleum Engineers of AIME, Dallas. 9 pp. SPE-1501.

266 Briggs, L.I., Jr.

1968 Geology of subsurface waste disposal in Michigan Basin. American Association of Petroleum Geology. 128-153. Memoir 10.

986 Briley, G.C.

1976 Conserve energy-refrigerate with waste heat. Hydrocarbon Processing 55(5):173-174. 
1892 Brookhaven National Laboratory.

1976 Proceedings of the ERDA Contractors' Review Meeting on Chemical Energy Storage and Hydrogen Energy Systems.

Brookhaven National Laboratory, Upton, NY. 210 pp. CONF-761134. (Microfiche).

885 Brothers, R.C. and C.P. Wilhite.

1975 Solar space heating with aquifer heat storage: a design study. Application of Solar Energy. CONF-750351. 293-304.

1253 Brown, D.L. and W.D. Silvey.

1973 Underground Storage and Retrieval of Fresh Water From a Brackish-Water Aquifer.

U.S. Geological Survey, Arlington. 379-419.

1172 Brown, D.W. and J.D. Hem.

1975 Reactions of Aqueous Aluminum Species at Mineral Surfaces. U.S. Geological Survey, Arlingon. 48 pp. Water-Supply Paper 1827-F.

1612 Brown, D. and W.D. Silvey.

1977 Artifical Recharge to a Freshwater Sensitive Brackish Water Sand Aquifer, Norfolk, VA.

U.S. Geological Survey, Arlington. Professional Paper 939.

9999dk Brown, E., M.W. Skougstad and M.J. Fishman.

1970 Methods for collection and analys is of water samples for dissolved minerals and gases.

U.S. Geological Survey, Arlington. Techniques of Water-Resources Investigations, Book 5, Chapter A1.

797 Brown, J.S.

1976 Mammoth waterflood due Ghawar Field.

$0 i 1$ and Gas Journa1 74(45):194-206.

1976 Aramco to use seawater for Saudi pressure maintenance. World 0 il 183:78-80.

1302 Brown, K.C.

1979 Solar Applications in Industry: A Framework for Market Assessment.

Solar Energy Research Institute, Golden, Co.

56 Brown, R.F. and D.C. Signor.

1974 Artifical recharge: state of the art. Ground Water 12(3):152-158.

57 Brown, R.H.

1953 Selected procedures for analyzing aquifer test data. American Water Works Association Journal 45:844-866. 
966 Brown, R.J.

1969 Thermal Pollution: Part 3. Hydrology and Hydrodynamics, Bibliography with Abstracts.

National Technical Information Service, Springfield, VA. 219 pp. NTIS/PS $-79 / 0258$.

887 Brummett, W.M., A.S. Emanuel, and J.D. Ronquille.

1976 Reservoir description by simulation at SACROC: a case history. Journal of Petroleum Technology 28:1241-1255.

264 Brun, G.

1967 Le Stockage Thermique Dans Le Sol: En Vue De La Regularisation De L'Energie Solaire.

Comples 13:39-44.

265 Brune, G.

1970 How much underground water storage capacity does Texas have? Water Resources Bulletin 6(4):588-601.

798 Brunton, G.D., D.M. Eissenberg, and R.J. Ked1.

1979 Low-Temperature Thermal Energy Storage Program: Annual Progress Report for October 1977-September 1978. Oak Ridge National Laboratory, Oak Ridge, TN. 97 pp. ORNL/TM-6701.

1705 Brutsaert, W. and M.Y. Corapcioglu.

1976 Pumping of aquifer with viscoelastic properties. Journal of Hydraulics Division Nov:1663-1675.

1304 Bryan, W.L.

1977 Recovery of waste heat from drying citrus by-products. American Institute of Chemical Engineers Symposium Series. $73: 25-31$.

174 Building Research and Practice.

1974 Heat pump power for U.S. flats.

Building Research and Practice 2(1):51.

1388 Bu11, W.B.

1973 Geologic factors affecting compaction of deposits in a 1 and-subsidence area. Geological Society of America Bulletin 84:3783-3802.

263 Bullen, R.S. and T.F. Bratrud.

1976 Fracturing with foam. Journal of Canadian Petroleum Technology 15(2):27-32.

987 Bullock, C.E., W.R. Reedy and G.C. Groff.

1979 Cool Storage as a Means for Residential Air Conditioning Electrical Load Management. American Chemical Society, Washington, DC. 528-533. 
58 Bundy, F.P., C.S. Herrick, and P.G. Kosky.

1976 The Status of Thermal Energy Storage.

Corp. Research and Development Dist., Power Systems Laboratory. 137 pp. No. 76CRD041.

619 Bureau of National Affairs, Inc.

1979 EPA proposed hazardous waste regulations under the Resource Conservation and Recovery Act.

Environmental Reporter 9(34):1580-1581.

654 Buretta, R.J. and A.S. Berman.

1976 Convective heat transfer in a liquid saturated porous layer. Journal of Applied Mechanics 43(E-2):249-253.

655 Burlingame, M.V.

1965 Aquifer storage ideal for natural gas.

Pipe Line Industry Feb:32-65.

13151 Burns, P. and C.B. Winn and J. Leflar.

1979 Preliminary analysis of a total solar heating system. Proceedings of Solar Energy Storage Options, San Antonio, TX. March 19-20. 1:137-148. CONF-790328-P1.

1894 Burolla, V.P. and J.J. Bartel.

1978 High Temperature Compatibility of Nitrate Salts, Granite Rock and Pelletized Iron Ore.

Sandia Laboratories, Albuquerque, NM. 32 pp. SAND-79-8634. (Microfiche).

888 Burt, R.A., F.A. Haddenhorst, and J.C. Hartford.

1975 Review of Bell Creek waterflood performance: Powder River, Montana.

Journal of Petroleum Technology 27:1443-1449.

9999du Buscheck, T.E.

1980 Probabilistic Simulation of Subsurface Fluid Flow: a Study Using a Numerical Scheme.

Lawrence Berkeley Laboratory, Berkeley, CA. 187 pp. LBL-10711.

900 Business Publishers, Inc.

1980- Energy Resources and Technology.

Business Publishers, Inc., Silver Springs, MD. 8(7-).

1513 Business Publishers.

1980- Solar Energy Intelligence Report.

Business Publishers, Silver Springs, MD. 6(23-).

1430 Busse, F.H. and D.D. Joseph.

1972 Bounds for heat transport in a porous layer. Journal of Fluid Mechanics 54(3):521-543. 
1884 Cagle, D.B. (ed).

1979 Final Proceedings of the Second Solar Heating and Cooling Commercial Demonstration Program Contractors' Review: Volume 3, Demonstrated Project Papers and Appendices.

Alabama University, Huntsville, AL. $760 \mathrm{pp}$. DOE/CS/4131-1(Vol.3). (Microfiche).

1550 Calamai, A., P. Ceron, G. Ferrara and G. Manetti.

1973 A Reinjection experiment in the Vico 1 Well. Geothermics 2(3-4):117-118.

1834 Caldwell, R.T., J.W. McDonald and A. Pietsch.

1965 Solar-energy receiver with lithium-hydride heat storage. Solar Energy 9(1):48-60.

1250 California, (St); Dept of Water Res and Univ of CA, Dept of

Civil Eng and Geotech Eng.

1971 Sea Water Intrusion: Aquitards in the Coastal Ground Water Basin of Oxnard Plain, Ventura County.

State of Calif., Department of Water Resources, 567 pp. Bulletin No. 6304.

1652 California, State of.

1978 Health Aspects of Wastewater Recharge: a State of the Art Review. Water Information Center, Huntington, NY. 240 pp.

262 Calm, J.M.

1978 Recovery of Wasted Heat with Centralized and Distributed Heat Pump Systems.

Argonne National Laboratory, Argonne, IL. 6 pp.

1979 Heat pump systems for district heating and cooling. ASHRAE Journal Sept:54-58.

1979 The DOE Heat Pump Centered Integrated Community Energy Systems Project.

Heat Pump Technology Information Exchange Meeting, Gaithersburg, MD. CONF-790362-1.

1980 Heat-Pump-Centered Integrated Community Energy Systems: System Development Summary.

Argonne National Laboratory, Argonne, IL. 113 pp. ANL/CNSV-7.

1469 Calm, J.M. and G.R. Sapienza.

1980 Suitability of the CASES Software for Evaluation of District Heating Systems Based on Annual Storage Cycles. Argonne National Laboratory, Argonne, IL. 15 pp. ANL/CNSV-TM-40. 
1288 Calm, J.M. and G.R. Sapienza.

1979 Intergrated Community Energy Systems Engineering Analys is and Design Bibliography. Argonne National Laboratory, Argonne, IL. 421 pp. ANL/CNSV-2. ICES.

1907 Cambe 1, A.B.

1981 Impact of customer side thermal energy storage on electric utility load management.

Technical and Economic Analysis Meeting, Chicago, April 22.

1394 Came1i, G.M. and E. Carabelli.

1975 Seismic control during a reinjection experiment in the Viterbo Region (Central Italy).

Proceedings of the Second U.N. Symposium on the Development and

Use of Geothermal Resources, San Francisco, May 20-29. 1329-1334.

59 Campbe11, M.D. and G.R. Gray.

1975 Mobility of well-drilling additives in the ground-water system. pp. 261-288 in Environmental Aspects of Chemical Use in Well Drilling Operations, U.S. EPA. EPA-560/1-75-004.

60 Campbe11, M.D. and J.H. Lehr.

1973 Rural Water Systems Planning and Engineering Guide. Commission on Rural Water, Washington, DC.

1252 Canada Mortgage and Housing Corp.

1979 The Canadian Central Receiver Solar Utility Concept. Canada Mortgage and Housing Corp., Research \& Development Div., Ottawa, Canada. $21 \mathrm{pp}$.

1726 Canada Mortgage and Housing Corporation, Research and Development Division.

1979 Security and a Price Ceiling for Home Heating: the Potential of the Solar Utility for Stabilizing the Price of Low Grade Energy and Assuring its Continuous Availability. Canada Mortgage and Housing Corporation, Research and Development Division.

1727 Canada Mortgage and Housing Corporation, Technical Research Division.

1980 Strategic Plan for the Implementation of the Solar Utility Concept.

Canada Mortgage and Housing Corporation, Technical Research Division.

666 Capuano, L.E., Jr.

1979 How Geysers steam wells are drilled and equipped. World $0 i 1$ 188(2):69-72. 
1819 Carden, P.0. and 0.M. Williams.

1978 The Efficiencies of thermochemical energy transfer. Energy Research 2:389-406.

$1544 z$ Carling, R.W.

1980 Molten nitrate salt materials studies. Proceedings of the DOE Thermal and Chemical Storage Annual Contractors' Review Meeting. 94-99.

799 Carlson, F.M. and C.S. Land.

1976 Effects of compressibility and solution gas on the gas drive mechanism for 1 inear and radial systems. Journal of Petroleum Technology 28:1079-1086.

1351 Carlson, R.C.

1979 Economic Impacts of Energy Conservation and Renewable Energy Sources.

Lawrence Livermore Laboratory, Livermore, CA. UCRL-15087.

1069 Carnegie, E.J., P.W. Niles, J.A. Hoffman, W.B. Stine, and R.E. Boche.

1977 Design of a solar heat source for industrial dehydration. Proceedings of the 1977 Annual Meeeting, American Section of the International Solar Energy Society. 1:208-215.

889 Carpenter, D.H. and J.B. Davies.

1976 Energy yield of micellar flooding. Journal of Petroleum Technology 28:103-106.

1121 Carr, J.H., P.J. Hurley, and P.J. Martin.

1978 Applications of Thermal Energy Storage to Process Heat Storage and Recovery in the Paper and Pulp Industry: Final Report, Sept. 1977 -May 1978.

Boeing Engineering and Construction, Seattle. $240 \mathrm{pp}$. CONS $-5082-1$.

772 Carvel1, K.L. and P.A. Johnston.

1978 Environmental Effects of Right-of-Way Management on Forested Ecosystems. Electric Power Research Institute, Palo Alto, CA. EA 491.

61 Carver, J.A.

1978 Institutional aspects of utilizing heat storage in aquifers: a proposal for a prototype test. Proceedings of the Thermal Energy Storage in Aquifer Workshop, Lawrence Berkeley Lab. CONF-7805140.

62 Carver, J.A.

1975 Legal and institutional planning for macro-conservation measures. Public Utilities Fortnightly 95(9):29-33. 
890 Casamajor, A.B.

1978 The Application of Shallow Solar Ponds for Industrial Process Heat. Lawrence Livermore Laboratory, Livermore, CA. 17 pp. UCRL-81764.

1867 Casamajor, A.B. and R.E. Parsons.

1978 Design Guide for Shallow Solar Ponds.

Lawrence Livermore Laboratory', Livermore, CA. 74 pp. UCRL-52385. (Microfiche).

1868

1979 Design Guide for Shallow Solar Ponds. Lawrence Livermore Laboratory, Livermore, CA. 65 pp. UCRL-52385 (Rev1). (Microfiche).

261 Casazza, J.A., T.R. Schneider, and V.T. Sulzberger.

1976 Energy on call. IEEE Spectrum 3(6):44-47.

781 Castine 1, G. and M.A. Combarnous.

1975 Convection naturelle dans une couche poreuse anisotrope. Revue Senerale de Thermique 168:937-947.

260 Cavalleri, G. and G. Foligno.

1977 Proposal for the production and seasonal storage of hot water to heat a city. Solar Energy 19(6):677-683.

939 Cayais, J.L., M.E. Hayes, R.S. Schechter and W.H. Wade.

1976 Surfactant aging: a possible detriment to tertiary oil recovery. Journal of Petroleum Technology 8:985-987.

63 Cazal, A.

1964 Injection d'eau chaude dans une nappe a 1'aide de forage: etude thermique.

International Association Scientific Hydrology. 421-431.

$1482 \mathrm{cx}$ Cease, M.E.

1980 A Model of direct contact heat transfer for latent heat energy storage.

Energy to the 21st Century: 15th Intersociety Energy Conversion Engineering Conference, Seattle, WA, August 18-22. 1:624-629.

1173 Cederstrom, D.J., E.H. Boswe 11, and G.R. Tarver.

1979 Summary Appraisals of the Nation's Ground-Water Resources: South Atlantic-Gulf Region.

U.S. Geological Survey, Arlington. $35 \mathrm{pp}$. Professional Paper $813-0$.

780 Centrilift, Inc.

1979 Electrical Submersible Pumps: Expanding Opportunities for Their Profitable Use.

Centrilift, Inc. 14 pp. 
988 Cernoch, S.

1969 Thermodynamics of recuperation of waste heat from the combustion products of industrial furnaces.

Journal of the Iron and Steel Institute Dec:1578-1590.

1653 Cerruti, D.

1976 Dual phase annual cycle for residential heating and cooling. Sharing the Sun: Solar Technology in the 70's, Jt. Conf - Int'1 Solar En Soc, Am Sect and Solar En Soc of Canada 10:143-146.

1680 Cha, B.K., D.W. Connor and R.0. Mueller.

1979 Two-Tank Seasonal Storage Concept for Solar Space Heating of Buildings.

Argonne National Laboratory, Argonne, IL. 13pp. CONF-791226-2.

800 Chakravorty, S.K., P.R. Brown, and N. Endsin.

1978 A Review of waterflood performance in Garrington Cardium A and B Pools, Unit No. 2.

Journal of Petroleum Technology 30:869-876.

777 Chalmers, J.A. and E.J. Anderson.

1977 Economic/Demographic Assessment Manual: Current Practices, Procedural Recommendations, and a Test Case.

Mountain West Research, Inc., Tempe, AZ. 300 pp. PG-274 546.

1544 ae Chaney, S., N. Hayden and J.A.C. Humphrey.

1980 Experimental and theoretical study of thermocline degradation. Proceedings of the DOE Thermal and Chemical Storage Annual Contractors' Meeting. 118-121.

801 Chang, H.L.

1978 Polymer flooding technology: yesterday, today, and tomorrow. Journal of Petroleum Technology 30:1113-1128.

802 Chang, H.L., H.M. Al-Rikabi, and W.H. Pusch.

1978 Determination of 0 il/water bank mobility in micellar-polymer flooding. Journal of Petroleum Technology 30:1055-1060.

1070 Chapman, H.L.

1970 A Rock pile heating and cooling system. International Solar Energy Society Conference, Melbourne, Australia. Paper No. 6/54. 1-6.

64 Chappelear, J.E. and C.W. Volek.

1969 The Injection of a hot liquid into a porous medium. Society of Petroleum Engineers Journal 9(1):100-114.

1588 Charbeneau, R.J. and R.L. Street.

1979 Modeling groundwater flow fields containing point singularities: streamlines, travel times, and breakthrough curves. Water Resources Research 15(6):1445-1450. 
891 Charroppin, P., J. Despois, J.C. Fauconnier, and F. Nougarede.

1976 Underground heat storage in captive aquifers.

Proceedings, International Total Energy Congress, Copenhagen, Denmark. 460-495.

1426 Chase, C.A. and P.M. O'Dell.

1973 Application of variational principles to cap and base rock heat losses.

Society of Petroleum Engineers Journal 13(8):200-210.

1400 Chasteen, A.J.

1975 Geothermal steam condensate reinjection.

Proceedings of the Second U.N. Symposium on the Development and Use of Geothermal Resources, San Francisco, May 20-29. 1335-1336.

667 Chatas, A.T.

1976 The Estimation of aquifer properties from reservoir performance in water-drive fields. Journal of Pressure Technology 76-Pet-49:1-8..

1319 Chaturvedi, S., and R.W. Porter.

1978 Environmental effects of heat and moisture release from atmospheric spray cooling systems.

pp. 65-74 in Environmental Effects of Atmospheric Heat/Moisture Releases, American Sociey of Mechanical Engineers, N.Y.

1071 Chemical Week.

1978 Chemical mixture creates 'Midnight Sun'. Chemical Week 122(9):34-35.

1654 Chen, C.S. and D.L. Reddell.

1980 Temperature distribution around an injection well and evaluation of aquifer thermal properties. American Geophysical Union Transactions 61(17):230.

1245 Chern, W.S., and R.E. Just.

1979 A Generalized Model for Fuel Choices With Application to the Paper Industry.

U.S. Dept. of Energy, Energy Information Adm. and Office of Conservation and Solar Applications. 28 pp. CONF-79066-1.

1582b Cherne, J.

1980. Bethe1, Alaska: aquifer thermal energy storage project.

Mechanical, Magnetic, and Underground Energy Storage 1980 Annual Contractors' Review. pp. 10-16. CONF-801128.

989 Cherne, J., G. Gelb and D. Pinkerton.

1979 Solar Production of Industrial Process Steam. American Chemical Society, Washington, DC. 124-128. 
1522 Childs, S.W.

1980 Preliminary Interpretive Report: Heat and Mass Transfer in Unsaturated Porous Media. Oregon State University, Corvallis. 47 pp. (Draft).

1585 China, People's Republic of.

1979 Summary of Experience with Groundwater Recharge and Thermal Energy Storage in the People's Republic of China.

People's Republic of China. Translated by AD-EX, Portola Valley, CA. $396 \mathrm{pp}$.

65 Chow, $V$.

1951 Drawdown in artesian wells computed by nomograph.

Civil Engineering 21(10):48-49.

66

1952 On the determination of transmissibility and storage coefficients from pumping test data.

Transactions, American Geophysical Union 33(3):397-404.

990 Christensen, J.

1978 Heat cost in a Swedish agrothermal plant.

Nuclear Technology 40:227-233.

991 Chubb, T.A.

1979 NRL builds energy storage systems.

Design News Apr23:39.

$9999 d c$

1978 Thermal Energy Storage Material Comprising Mixtures of Sodium, Potassium and Magnesium Chlorides.

Department of the Navy, Washington. 4 pp. PAT-APPL-802 395;

PATENT 4119556.

1544u Chubb, T.A., J.J. Nemecek, D.E. Simmons and R.J. Veith.

1980 NRL energy storage program: 1980 report.

Proceedings of the DOE Thermal and Chemical Storage Annual

Contractors' Meeting. 78-80b.

603 Churchill, D.J.

1977 Flow Measurement and Characterization in Shallow Geothermal Systems Used for Downhole Heat Exchanger Applications.

M.S.Thesis, Oregon State University, Corvallis. 157 pp.

1375 Cigni, U., A. Giovannoni, E. Luschi and M. Vidali.

1970 Completion of producing geothermal wells.

UN Symposium on the Development and Utilization of Geothermal

Resources, Pisa, Italy, in Geothermics 2(1):757-763.

1376 Cigni, U., F. Fabbri, and A. Giovannoni.

1975 Advancement in cementation techniques in the Italian geothermal wells.

Proceedings of the Second U.N. Symposium on the Development and Use of Geothermal Resources, San Francisco, May 20-29. 1471-1481. 
9999dx City of Piqua, Ohio.

1979 District Heating and Cooling Systems for Communities through Power Plant Retrofit and Distribution Network: City of Piqua. City of Piqua, Ohio. 60 pp. Vol. 1. C00-4976-1.

1619 Claesson, J.

1978 Entropy Analysis of Numerical Diffusion.

Lund Institute of Technology, Department of Mathematical

Physics, Sweden. $11 \mathrm{pp}$.

1979 Thermodynamics of Sensible Heat Storage Systems: Thermality Concept .

Lund Institute of Technology, Department of Mathematical Physics, Sweden.

1980 Tilting Rate of a Wide Thermal Front. Lund Institute of Technology, Department of Mathematical Physics, Lund, Sweden. 6 pp.

1584 Claesson, J., B. Eftring, and G. Hellstrom (eds).

1980 An International Seminar on Heat Storage in Aquifers. Lund Institute of Technology, Department of Mathematical Physics, Lund, Sweden. Lund-MPh-80/13.

1767 Claesson, J., B. Eftring and G. Hellstrom.

1980 Temperature Decline of a Heated Region in the Ground. Lund University, Department of Mathematical Physics, Lund, Sweden. Lund-MPh-80/22.

1765 Claesson, J. and G. Hellstrom.

1980 Heat Storage in Aquifers: Thermohydraulic Considerations. Lund Institute of Technology, Department of Mathematical Physics, Lund, Sweden.

1620 Claesson, J. and M. Johansson.

1980 Continuous Heat Source Model for Ground Heat Storage. Lund Institute of Technology, Department of Mathematical Physics, Sweden. 31 pp. D34:1980.

1766 Claesson, J. and T. Bengtsson.

1978 Stationary Heat Losses from a Spherical or Ellipsoidal Heat Storage Volume Deep in the Ground. Lund Institute of Technology, Department of Mathematical Physics, Lund, Sweden.

1072 Clark, A.F., W.L. Ahlgren, J.A. Day, W.C. Dickinson, and W.G. Gensler.

1975 Experimental Performance of Shallow Solar Ponds. Solar Use Now a Resource for People: International Solar Energy Society Conference. 269. (Abstract). 
1072 Clark, A.F., W.L. Ahlgren, J.A. Day, W.C. Dickinson, and W.G. Gensler.

1975 Experimental Performance of Shallow Solar Ponds. Solar Use Now a Resource for People: International Solar Energy Society Conference. 269. (Abstract).

1544 ap Clark, E.C., D.K. Carlson and O.M. Morgan.

1980 The Sulfuric acid/water chemical heat pump/energy storage program.

Proceedings of the DOE Thermal and Chemical Storage Annual Contractors' Review Meeting. 170-173.

1193h Clark, E.C. and C.C. Hiller.

1978 Sulfuric acid/water chemical heat pump/energy storage system demonstration.

pp. 45-50 in Thermal Storage and Heat Transfer in Solar Energy Systems, American Society of Mechanical Engineers, New York.

1360b Clark, G. and C.P. Allen.

1979 Structural thermal mass and comfort cooling requirements of residences in various U.S. climates. Proceedings of Solar Energy Storage Options, San Antonio, TX, March 19-20. 1:339-344. CONF-790328-P2.

1835

1979 Sensible and Latent Cooling Requirements of Conventional and Passively Cooled Residences in American Climates. American Chemical Society. 269-273. Paper no. 799057.

668 Clark, J.B.

1949 A Hydraulic process for increasing the productivity of wells. Petroleum Transactions, AIME 1:1-8.

67 Clark, W.W.

1958 Know the enemies: a factual study of the electric heat pump. Gas $34: 57-62$.

267 Cliff, W.C., W.J. Apley and J.M. Creer.

1979 Evaluation of Potential Geothermal Well-Head Flow Sampling and Calorimeter Methods. Lawrence Berkeley Laboratory, Berkeley, CA. 25 pp. LBL-9248.

1544as Clinch, M.

1980 Metal Hydride CHP Technical Support.

Proceedings of the DOE Thermal and Chemical Storage Annual

Contractors' Review Meeting. 186a-186d.

1073 Close, D.J.

1965 Rock pile thermal storage for comfort air conditioning. Mechanical and Chemical Engineering Transactions May:11-23. 
1075 Close, D.J., R.V. Dunk le, and K.A. Robeson.

1968 Design and performance of a thermal storage air conditioning system.

Mechanical and Chemical Engineering Transactions May:45-54.

1076 Close, D.J. and T.L. Pryor.

1975 Energy Storage in Absorbent Beds.

Solar Use Now a Resource for People: International Solar Energy Society Conference. 191-192. (Abstract).

1785ap Cluff, C.B. and R.B. Kinney.

1980 Solar district heating model for an azimuth-tracking floating concentrator on a seasonal heat storage reservoir. Systems Simulation and Economics Analysis Conference, San Diego, January 23-25. 233-244. SERI/TP-351-431.

669 Coats, K.H., L.A. Rapoport, and J.R. McCord.

1964 Determination of aquifer influence function from field data. Journal of Petroleum Technology 6:1417-1424.

992 Cohen, G., J. Salvat, and A. Rojey.

1979 A New Absorption-Cycle Process for Upgrading Waste Heat. American Chemical Society, Washington, DC. 1720-1724.

68 Cole, M.H.

1970 Heat pumps today: part 1.

ASHRAE Symposium on Heat Pumps: Improved Design and Performance. $41-48$.

1549 Coleman, W.R.

1978 Use of thermal storage and/or HVAC tactics for utility load management. Proceedings of the American Power Conference 40:1470-1476.

803 Collie, M.J. (ed).

1978 Geothermal Energy: Recent Developments. Noyes Data Corporation, Park Ridge, NJ. 445 pp.

804 Collie, M.J., (ed).

1979 Heat Pump Technology for Saving Energy. Noyes Data Corporation, Park Ridge, NJ. 348 pp.

69. Collins, A.G.

1970 Are 0il- and Gas-Well Drilling, Production and Associated Waste Disposal Practices Potential Pollutants of the Environment? American Chemical Society, Washington, DC. 14 pp. CONF-700911-6.

$19710 i 1$ and gas wells: potential polluters of the environment? Water Pollution Control Federation Journal 43:2383-2393. 
70 Collins, A.G.

$19710 i l$ and gas wells: potential polluters of the environment? Water Pollution Control Federation Journal 43:2383-2393.

71

1975 Chemical applications in oil- and gas-well drilling and completion operations.

pp. 231-260 in Environmental Aspects of Chemical Use in Well Drilling Operations, U.S. EPA. EPA-560/1-75-004.

72

1975 Possible contamination of ground waters by oil- and gas-well drilling and completion fluids.

Environmental Aspects of Chemical Use in Well Drilling Operations. 37 pp. CONF-7505133-1.

1977 Enhanced-0il-Recovery Injection Waters.

Society of Petroleum Engineers, Dallas, SPE-6603. 153-166.

1383p Collins, R.E.

1980 High temperature underground thermal energy storage system for solar energy.

Thermal Energy Storage: Fourth Annual Review Meeting, Tysons Corner, VA, Dec. 3-4. 163-172. CONF-791232.

75 Collins, R.E., J.R. Fanchi, G.0. Morrell, K.E. Davis, T.K. Guha and R.L. Henderson.

1937 High temperature underground thermal energy storage. Proceedings of the Thermal Energy Storage in Aquifer Workshop, Lawrence Berkeley Lab. 5 pp. CONF-780514C1978.

74 Collins, R.E. and K.E. Davis.

1976 Geothermal storage of solar energy for electric power generation. Proceedings, International Conference on Solar Heating and Cooling, University of Florida. 411-424.

1334 Colsher, C.S. and A.R. Evans.

1978 The Transfer of Energy Conservation Technology to Industry: A Preliminary Survey of Existing Mechanisms. Argonne National Laboratory, Integrated Assessments and Policy Evaluations Group, Argonne, IL. 49 pp. ANL/EES-TM-28.

628 Combarnous, M.A. and S.A. Bories.

1975 Hydrothermal convection in saturated porous media. pp. 231-307 in V.T. Chow, ed, Advances in Hydroscience, Academic Press, Cambridge. Vol. 10.

76 Committee on Natural Resources.

1974 An Act Relating to Conservation of Geothermal Resources. State of Washington, 43rd Legislature, 3rd Extraordinary Session. Substitute House Bill No. 135. 13 pp. 
805 Connor, D.W. and R.0. Mueller.

1979 The Elementary General Theory of Stratified Solar-Thermal Systems. Argonne National Laboratory, Argonne, IL.

806

1979 Analysis and Simulation of Stratified Heat Storage in Solar-Thermal Systems.

Argonne National Laboratory, Argonne, IL.

1468 Consultant Review Team.

1980 Review Report on the Seasonal Thermal Energy Storage Program. Consultant Review Team for Pacific Northwest Laboratory, Battelle, Richland, WA. 16 pp.

1793

1981 Review Report on the Seasonal Thermal Energy Storage Program. Consultant Review Team for Pacific Northwest Laboratory, Battelle, Richland, WA. 16 pp.

819 Cook, T.D. (ed).

1972 Underground Waste Management and Environmental Implications. American Association of Petroleum Geologists, Tulsa, OK. 412 pp. Memoir 18.

1704 Cooke, W.L.

1970 Some methods of dealing with low enthalpy water in the Rotorua Area of New Zealand. U.N. Symposium on the Development and Utilization of Geothermal Resources 2(3):1670-1675.

1582n Cooley, C.H., L.B. Owen, C.K. Blair and G.J. Banik.

1980 Flow facility development and laboratory analysis.

Mechanical, Magnetic, and Underground Energy Storage 1980 Annual Contractors' Review. pp. 96-102. CONF-801128.

597 Cooley, R.L. and A.B. Cunningham.

1977 Consideration of Total Energy Loss in Theory of Flow to Wells. University of Nevada, Desert Research Institute, Water Resources Center, Reno. 55 pp. PB-264 717.

269 Cooley, R.L. and P.J. Sinclair.

1976 Uniqueness of a model of steady - state groundwater flow. Journal of Hydrology 31(3-4):245-269.

77 Cooper, H.H. and C.E. Jacob.

1946 A Generalized graphical method for evaluating formation constants and summarizing well-field history. Transactions, American Geophysical Union 27(4):526-534.

670 Cooper, L.Y.

1977 Heat storage in the ground mass surrounding deep dry wells. ASME Winter Annual Meeting, Heat Transfer in Energy Conservation. 99-105. 
1544q Copeland, R.J.

1980 Systems analysis of thermal storage.

Proceedings of the DOE Thermal and Chemical Storage Annual

Contractors' Review Meeting. 65-68.

1543 Copel and, R.J., J.D. Wright and C.E. Wyman.

1980 The SERI Solar Energy Storage Program.

Solar Energy Research Institute, Golden, Co. $11 \mathrm{pp}$.

SERI/TP-333-497.

1486 Copel and, R.J., M.E. Karpuk and J.L. U1 lman.

1980 A Preliminary Screening of Thermal Storage Concepts for Water/Steam and Organic Fluid Solar Thermal Receiver Systems. Solar Energy Research Institute, Golden, C0. $50 \mathrm{pp.}$ SERI/TR-631-647.

78 Cormary, Y., P. Iris, J.P. Marie, G. DeMarsily, H. Michel, and M.F. Zaquine.

1978 Heat storage in a phreatic aquifer: Campuget experiment (Gard, France).

Proceedings of Thermal Energy Storage In Aquifer Workshop. Lawrence Berkeley Laboratory. CONF-7805140.

79 Corte 11, B.

1977 Ground water/solar heat. Water Well Journal 11(5):73.

$1177 k$ Corwin, R.F. and H.F. Morrison.

1978 Self-potential studies at Cerro Prieto. Pages 34-36 in Earth Sciences Division Annual Report, Lawrence Berkeley Laboratory, Berkeley, CA. LBL-8648.

80 Cosner, S.R. and J.A. Apps.

1978 A Compilation of Data on Fluids from Geothermal Resources in the United States.

Lawrence Berkeley Laboratory, Berkeley, CA. LBL-5936. 108 pp.

$1193 i$ Costello, V.A., S.S. Melsheimer and D.D. Edie.

1978 Heat transfer and calorimetric studies of a direct contact-latent heat energy storage system. pp. 51-60 in Thermal Storage and Heat Transfer in Solar Energy Systems, American Society of Mechanical Engineers, New York.

1721 Cottingham, J.G.

1978 Cost-Effective Potential of Optimumly Designed Heat Pumps for the Collection, Storage and Distribution of Solar Energy. Brookhaven National Laboratory. Upton N.Y. 9 pp. BNL-25195.

81 Coulbois, P. and J.P. Herault.

1975 Conditions for the competitive use of geothermal energy in home heating.

Proceedings of the Second U.N. Symposium on the Development and Use of Geothermal Resources. 3:2104-2108. 
1883 Cowen, D.S. and E.J. Daniels.

1980 Optimization technique for minimizing the cost of self-powering industrial HVAC Systems.

SERI Second Annual Systems Simulation and Economics Analys is

Conference, San Diego, January 23-25. CONF-800101. (Microfiche).

893 Cox, D., R.V. Westermark, and G. Johnson.

1976 Operations optimized in remote field.

$0 i 1$ and Gas Journal 74(11):94-102.

1289 Crane, R.E., H.G. Lorsch and R.G. Werden.

1979 Heat Pump Centered Integrated Community Energy Systems: System Development, Franklin Research Center Interim Report.

Argonne National Laboratory, Argonne, IL. ANL/ICES-TM-26.

268 Crawford, M.

1977 Transient Conduction in the Space Surrounding a Ring of Holes. American Society of Mechnical Engineers, New York. 8 pp. 77-WA/HT-12.

82 Crichlow, H.B.

1972 Heat Transfer in Hot Fluid Injection in Porous Media. Ph.D Thesis. Stanford University, Stanford, CA. 223 pp.

1077 Cropsey, M.G.

1964 Soil as a heat storage source for an air to air heat pump. American Society of Agricultural Engineers Transactions $7(1): 52-55$.

1309 Crow, N.B.

1979 An Environmental Overview of Geothermal Development: The Geysers - Calistoga KGRA. Lawrence Livermore Laboratory, Livermore, CA. Vol. 4, Rev. 1. 72 pp. UCRL -52496 .

1122 Ctvrtnicek, T.E., R.J. McCormick, R.W. Serth, A. Wojtowicz, and D.L. Zanders.

1978 Slag Waste Heat Recovery and Utilization in the Elemental Phosphorus Industry: Final Report, Oct. 28, 1977-April 30, 1978. Monsanto Research Corporation, Dayton, OH. 242 pp. CONS-5088-1.

83 Cuellar, G.

1975 Behavior of silica in geothermal waste waters. Proceedings of the Second U.N. Symposium on the Development and Use of Geothermal Resources. 1343-1347.

807 Culver, G.G.

1976 Optimization of Geothermal Home Heating Systems. Oregon Institute of Technology, Geo-Heat Utilization Center, Klamath Falls, OR. 46 pp. 
604 Culver, G.G., J.W. Lund, and L.S. Svanevik.

1974 Klamath Falls Hot Water Well Study.

Oregon Institute of Technology, Klamath Falls.

84 Culver, G.G. and G.M. Reistad.

1977 Evaluation and Design of Downhole Heat Exchangers for Direct Application.

Geothermal Energy Update 78(8):1337.

85

1978 Testing and Modeling of Downhole Heat Exchangers in Shallow Geothermal Systems.

Geothermal Resource Council Transactions 3:129-131.

618 Cummings, R.G., G.E. Morris, J.W. Tester, and R.L. Bivins.

1979 Mining earth's heat: hot dry rock geothermal energy. Technology Review 81(4):58-68.

$1315 i$ Curran, H.M. and S. Heibein.

1979 Thermal storage for solar Rankine and absorption cooling systems. Proceedings of Solar Energy Storage Options, San Antonio, TX. March 19-20. 1:97-106. CONF-790328-P1.

671 Curry, D.M. and J.E. Cox.

1973 The Effect of the Porous Material Characteristics on the Internal Heat and Mass Transfer.

American Society of Mechanical Engineers, New York. 13 pp. 73-HT-49.

1781 D'Hooge, J.A., C.Q. Sheely, and B.J. Williams.

1980 Interwell radioactive tracers: an effective reservoir evaluation tool, West Sumatra field results.

Society of Petroleum Engineers of AIME, New York. 6 pp. SPE-8434.

1873 Dahlgren, T. and D. Lewis.

1979 System for Heat Storage in Metal Hydrides.

Studsvik Energiteknik AB, Nykoeping, Sweden. 35 pp.

STUDV IK/E-1-79/55. (Microfiche).

1755 Daly, C.J.

1979 Analytical Numerical Methods for Groundwater Flow and Quality Problems.

Ph.D. Thesis, Colorado State University, Fort Collins, C0. 167 pp.

1078 Daniels, D.G. and M.F. Merriam.

1975 Fluid Dynamics of Selective Withdrawal in Solar Ponds. Solar Use Now a Resource for People: International Solar Energy Society Conference. 267-268.

894 Danielson, H.H., W.T. Paynter, and H.W. Milton, Jr.

1976 Tertiary recovery by the maraflood process in the Bradford Field. Journal of Petroleum Technology 18:129-138. 
1177 t Davey, J.V. and J.H. Howard.

1978 Geothermal resources and the U.S. pulp and paper industry. Pages 66-67 in Earth Science Division Annual Report, Lawrence Berkeley Laboratory, Berkeley, CA. LBL-8648.

1504 Davidson, E.S.

1979 Summary Appraisals of the Nation's Ground-water Resources: Lower Colorado Règion.

U.S. Geological Survey, Washington. 23 pp. maps. Professional Paper 813-R.

673 Davidson, E. and M. Fox.

1974 Effects of off-road motorcycle activity on Mojave Desert vegetation and soil. Madrono 22(8):381-412.

993 Davis, D.C., J.S. Romberger, C.A. Pettibone, and G.A. Kranzler. Waste Heat from Food Processing Plants in the Pacific Northwest. Washington State University, College of Agriculture Research Center, Pullman, WA. 12 pp. Scientific Paper No. 5298.

672 Davis, E.G. and M.F. Hawkins.

1964 Linear fluid-barrier detection by well pressure measurements. Journal of Technology 16:259-260.

273 Davis, G.H. and J.R. Rollo.

1969 Land subsidence to decline of artesian head at Baton Rouge, Lower Mississippi Valley, USA.

USA Proceedings of Tokyo Symposium on Land Subsidence. IASH/AIHS Unesco. 174-184.

1681 Davis, K.E.

1975 Deep well disposal of industrial wastes. Industrial Wastes Jan/Feb:28-30.

1702

1974 Subsurface disposal of industrial wastes. Industrial Waste Engineering Sept/0ct:14-17.

1703

1972 Control of unconsolidated sands in waste-disposal wells. pp. 112-118 in Underground Waste Management and Environmental Implications, American Association of Petroleum Geologists.

1658 Davis, S.N., G.M. Thompson, H.W. Bentley and G. Stiles.

1980 Ground-water tracers: a short review. Groundwater 18(1):14-23.

1413 Davison, J.E. and I.0. Salyer.

1980 Electron Beam Irradiation of High Density Polyethylene Pellets for Thermal Energy Storage: Final Report of Task 1 and Task 2 for the Period Jan. 5, 1979 to Jan. 4, 1980. 
Oak Ridge National Laboratory, Oak Ridge, TN. 60 pp. ORNL/Sub-7641/1.

1266 Davison, R.R., W.B. Harris, and D.L. Reddell.

1979 Storage of Cold Water in Aquifers.

Texas A\&M University, College Station. 11 pp.

86 Davison, R.R., W.B. Harris and J.H. Martin.

1975 Storing sunlight underground: the Solaterre system. Chemtech 5(12):736-741.

1679 Davitian, H. and R.W. Leigh.

Method for the Comparative Economic Assessment of Energy Storage Systems.

Brookhaven National Laboratory. 15 pp. BNL-25291.

87 Day, J.A., A.F. Clark, W.C. Dickinson, and A. Iantuono.

1975 Industrial Process Heat From Solar Energy. Lawrence Livermore Laboratory, Livermore, CA. UCRL-76390. 750-758. (Preprint).

1815 Dayan, J., A.S. Foss and S. Lynn.

1977 Evaluation of a chemical heat storage system for a solar steam power plant.

Proceedings of the 12th Intersociety Energy Conversion

Engineering Conference, Washington, August 28-September 2. $1181-1188$.

272 DeMarsily, G.

1978 Peut-on stocker de 1'energie dans le sol?

Annales Des Mines April:11-24.

808 DeRenzo, D.J. (ed).

1978 European Technology for Obtaining Energy from Solid Waste. Noyes Data Corporation, Park Ridge, NJ. 281 pp.

$1544 a b$ DeVan, J.H. and P.F. Tortorel1i.

1980 Mass-transfer characteristics of nitrate-based salt mixtures. Proceedings of the DOE Thermal and Chemical Storage Annual Contractors' Review Meeting. 106-108.

95 Dewalle, D.R. and J.L. Richenderfer.

1974 Field Prototype: Description and Operation. Pennsylvania State Univ., Institute for Research on Land and Water Resources. No. 86. 83-92.

1123 Dean, T.S.

1978 Thermal Storage.

Franklin Institute Press, Philadelphia, PA. $61 \mathrm{pp.}$

1273 Deans, H.A.

1963 A Mathematical model for dispersion in the direction of flow in porous media. 
Society of Petroleum Engineers Journal 3(3): 49-52.

1624 Defferding, L.J.

1980 State of the Art of Liquid Waste Disposal for Geothermal Energy Systems: 1979.

U.S. Department of Energy, Environmental Control Technology

Division, Washington. DOE/EV-0083.

1460 Delaney, J.M. and H.C. Helgeson.

1978 Calculation of the thermodynamic consequences of dehydration in subducting oceanic crust to $100 \mathrm{~KB}$ and $>800 \mathrm{C}$. American Journal of Science 278:638-686.

674 Delclaud, J.P.

1972 New Results on the Displacement of a Fluid by Another in a Porous Medium.

Society of Petroleum Engineers of AIME, Dallas. 20 pp. SPE-4103.

88 Dellinger, T.B. and B.J. Livesay.

1973 Diamond-bit research provides basic drilling parameters.

$0 i 1$ and Gas Journal 70(3):86-95.

89 Denis, L.H.D., A.J.H. Bedue and J. Malherbaud.

1979 Method of and Arrangement for the Seasonal Storage and Use of Hot Water Produced in Particular by Electrical Power-Generating Thermal and Nuclear Stations.

U.S. Patent No. 4,159,736.

90 Denison, E.B.

1976 Making downhole measurements through modified drill pipe. World 0 il 183(5):86-69.

1976 Downhole measurements through modified drill pipe. Journal of Pressure Technology 76-Pet-53:1-6.

271 Denson, K.H., A. Shindala, and C.D. Fenn.

1968 Permeability of sand with dispersed clay particles. Water Resources Research 4(6):1275-1276.

92 Desert Reclamation Industries.

1978 Aquifer Storage at J. F. Kennedy International Airport. Desert Reclamation Industries, Plainfield, NJ. $42 \mathrm{pp}$

980 Design News.

1978 Barrel of heat stores sun's energy.

Design News Feb6:30-31.

94 Despois, J. and F. Nougarede.

1977 Underground heat storage.

Revue Generale de Thermique 184:357-366. 
676 Despois, J. and F. Nougarede.

1976 Underground storage of heat.

Annual Meeting, French Society of Heat Engineers, Thermal

Aspects of Today's Energy Problems, Grenoble, France. 13 pp.

1893 Dickey, J.W., J.T. Beard, F.A. Iachetta and L.U. Lilleleht.

1976 Annual Collection and Storage of Solar-Heated Water for the Heating of Buildings.

Virginia University, Charlottesville. 8 pp. CONF-760633-1.

(Microfiche).

270 Dickinson, W.C., A.F. Clark, J.A. Day, and L.F. Wouters.

1976 The Shallow solar pond energy conversion system.

Solar Energy 18(1):3-10.

1251 Dilworth, Secord, Meagher and Associates, Limited.

1979 The Potential Thermal Performance and Economic Viability of Solar Utilities in Canada.

Canada Mortgage and Housing Corp., Ottawa, Canada. DSMA Report No. $1041 / 1008$.

1125 Divine, T.E., D.P. Alzheimer, and W.F. Smith.

1976 Estimates of Process Energy Use in Four Key Food Products Industries.

Pacific Northwest Laboratory, Battelle, Richland, WA. 53 pp.

Final Report. 300A00990.

678 Dobbs, R.K.

1969 Effective Exploration Inspection. Foundation Sciences, Inc. News letter 3(2),4(1) and 5(1).

677 Dobrynin, V.M.

1962 Effect of overburden pressure on some properties of sandstones. Society of Petroleum Engineers Journal 2(12):360-366.

96 Dodd, F.J., A.E. Johnson, and W.C. Ham.

1975 Material and corrosion testing at the Geysers Geothermal Power Plant.

Proceedings of the Second U.N. Symposium on the Development and Use of Geothermal Resources. 1959-1963.

1582y Doherty, T.J.

1980 Reservoir stability studies.

Mechanical, Magnetic, and Underground Energy Storage 1980 Annual Contractors' Review. pp. 184-191. CONF-801128.

1745 Domanski, P. and G.E. Kelly.

1980 Estimating the Heating Seasonal Operating Cost of Residential Hybrid Heat Pump Systems: Including Units Retrofitted to 0il, Gas, Electric Furnaces.

National Bureau of Standards, Washington. 37 pp. NBSIR 80-2090. 
1700 Domenico, P.A. and M.D. Mifflin.

1965 Water from low-permeability sediments and 1 and subsidence. Water Resources Research 1(4):563-576.

1699 Domenico, P.A. and V.V. Palciauskas.

1973 Theoretical analysis of forced convective heat transfer in regional ground-water flow. Geologica1 Society of America Bulletin 84:3803-3814.

679 Domestic Heating News.

1974 Heat pump takes on a11 comers. Domestic Heating News 13(5):24-26.

97 Donaldson, E.C., B.A. Baker and H.B. Carroll.

1977 Particle Transport in Sandstones.

Society of Petroleum Engineers, Dallas. SPE-6905. 20 pp.

98 Donaldson, I.G.

1962 Temperature gradients in the upper layers of the earth's crust due to convective water flows. Journal of. Geophysical Research 67(9):3449-3459.

630 Dooley, J.L., G.P. Frost, L.A. Gore, R.P. Hammond, D.L. Rawson and S.L. Ridgeway.

1977 A Feasibility Study of Underground Energy Storage Using High-Pressure, High-Temperature Water: Final Report. R\&D Associates, Marina del Rey, CA. RDA-TR-7100-001.

809 Doscher, T.M. and F.A. Wise.

1976 Enhanced crude oil recovery potential: an estimate. Journal of Petroleum Technology 28:575-585.

1354 Doughty, C., D. McEdwards and C.F. Tsang.

1979 Multiple We 11 Variable Rate We 11 Test Analysis of Data from the Auburn University Thermal Energy Storage Program. Lawrence Berkeley Laboratory, Earth Sciences Division, Berkeley, CA. 26 pp. LBL 10194.

1126 Dow Chemical Company.

1975 Evaluation of New Energy Sources for Process Heat. National Science Foundation. 143 pp. PB-245 604.

680. Downing, R.S. and F.A. Morrison, Jr.

1976 Convective and dispersive transport in a porous medium. Computers and Fluids 4:65-75.

994 Draper, A.B.

1979 Cupolas Minimize the Energy Required to Melt Ferrous Alloys. American Chemical Society, Washington, DC. 1664-1646. 
1134 Drexel University, United Technologies Research Center and Mathematica, Inc.

1977 Industrial Applications Study.

Drexel University, Philadelphia. Vol. 3. 99 pp. C00-2862-3.

1135 Drexel University, United Technologies Research Center and Mathematica, Inc.

1977 Industrial Applications Study.

Drexel University, Philadelphia. Vol. 4. 102 pp. C00-2862-4.

1230 Drexel University, United Technologies Research Center and Mathematica, Inc.

1976 Industrial Applications Study.

Mathematica, Inc. C00/2862-1. (Microfiche).

1231 Drexel University, United Technologies Research Center and

Mathematica, Inc.

1976 Industrial Applications Study.

Mathematica, Inc. Vol.2. C00/2862-2/2. (Microfiche).

1232 Drexel University, United Technologies Research Center and Mathematica, Inc.

1977 Industrial Applications Study.

Mathematica, Inc. Vol. 4. CO0/2862-4/4. (Microfiche).

1582w Driggs, C.L.

1980 Adiabatic compressed air energy storage in hard rock.

Mechanical, Magnetic, and Underground Energy Storage 1980 Annual

Contractors' Review. pp. 147-176. CONF-801128.

1582u Drost, M.K., R.W. Reilly, J.K. Young and F.R. Zaloudek.

1980 PNL second generation concepts studies.

Mechanical, Magnetic, and Underground Energy Storage 1980 Annual

Contractors' Review. pp. 131-136. CONF-801128.

99 Drost, $W$.

1973 Application of groundwater measurements by means of

radioisotopes on groundwater exploration.

World Congress on Water Resources. 357-369. CONF-7309143-11.

1292 Dubin, F.S., A. Halfon and P. Herzog.

1979 Heat Pump Centered Integrated Community Energy Systems: System Development, Dubin-Bloome Associates Interim Report.

Argonne National Laboratory, Argonne, IL. 229 pp. ANL/ICES-TM-29.

1211 Dudgeon, C.R. and P.S. Huyakorn.

1976 Effects of Near-Well Permeability Variation on Well Performance. Australian Department of Natural Resources, Australian Water Resources Council. 132 pp. Paper No. 18. 
100 Dudgeon, C.R. and R.J. Cox.

1976 Drilling Mud Invasion of Unconsolidated Aquifer Materials. Australian Department of Natural Resources, Australian Water Resources Counci1, Paper No. 17. 216 pp.

995 Dudley, J.C.

1973 Thermal Energy Storage in Air Conditioning: A Means for Reducing Peak Electrical Power Demand. Engineering Mechanical. 1540B. (Abstract).

1820 Duffy, T.E. and D.A. Rohy.

1979 Methods of and apparatus for energy storage and utilization. U.S. Patent \# 4,161,211.

1300 Durfor, C.N., and E. Becker.

1965 Public Water Supplies of the 100 Largest Cities in the United States, 1962.

U.S. Geological Survey, Arlington. 364 pp. Water-Supply Paper 1812 .

996 Duscha, R.A. and W.J. Masica.

1978 Thermal storage for industrial process and reject heat. Second Conference on Waste Heat Management and Utilization. $11 \mathrm{pp}$. DOE/NASA $/ 1034-78 / 3$.

1079 Duval1, G.D.

1976 Operational evaluation of a closed Brayton cycle laboratory engine.

11th Intersociety Energy Conversion Engineering Conference. $1: 171-176$.

1533 Dvoracek, M.J. and S.H. Peterson.

1971 Development of Systems for Ground Water Recharge into the Ogallala Formation.

Texas Technical University, Water Resources Center, Lubbock, TX. PB-202 630 .

101 Dvorov, I.M. and N.A. Ledentsova.

1975 Utilization of geothermal water for domestic heating and hot water supply.

Proceedings of the Second U.N. Symposium on the Development and Use of Geothermal Resources. 3:2109-2116.

1454k Dwyer, P.R.

1980 Combination central heat steam and heat pump installation: a comparison of a school with and without heat recovery. Official Proceedings, 71st Annual Conference of the International District Heating Assn, Harbor Springs, MI, June 23-25. Sec 17.

681 Dybbs, A. and S. Schweitzer.

1973 Conservation equations for nonisothermal flow in porous media. Journal of Hydrology 20:171-180. 
1175 Eakin, T.E., D. Price, and J.R. Harrill.

1976 Summary Appraisals of the Nation's Ground-Water Resources: Great Basin Region.

U.S. Geological Survey, Arlington. 37 pp. Professional Paper $813-\mathrm{G}$.

810 Earlougher, R.C.

1977 Advances in Well Test Analysis.

Society of Petroleum Engineers of AIME, New York. 264 pp.

9999ec Ebeling, L., D.L. Redde11, S. Tostengard, W.B. Harris, and R.R. Davison.

1979 Effect of system size on the practicality of aquifer storage. Sun 2: Proceedings of the International Solar Energy Society Silver Jubilee Congress, Atlanta, GA, May 1979. 1:629-633.

102 Ebeling, L.L. and D.L. Redde 11.

1976 Energy (Hot Water) Storage in Groundwater Aquifers. American Society of Agricultural Engineers. Paper No. 76-2540. $20 \mathrm{pp}$.

1364 Eberle, M. and J.L. Persons.

1978 Appropriate Well Drilling Technologies: A Manual for Developing Countries.

National Water Well Association, Worthington, OH. 95 pp.

103 Eckert, A.W.

EPA jurisdiction over well injection under the Federal Water Pollution Control Act.

Natural Resources Lawyer 9(3):455-465.

1544 aj Edde, $\mathrm{H}$.

1980 Collection and dissemination of thermal energy storage system information for the pulp and paper industry.

Proceedings of the DOE Thermal and Chemical Storage Annual

Contractors' Review Meeting. 148-151.

1311 Edesess, M., J. Henderson and T.S. Jayadev.

1976 A Simple Design Tool for Sizing Solar Ponds.

Solar Energy Research Institute, Golden, C0. 32 pp.

SER I /RR-351-347.

1383 an Edie, D.D., S.S. Melsheimer and J.C. Mullins.

1980 Immiscible fluid: heat of fusion heat storage system.

Thermal Energy Storage: Fourth Annual Review Meeting, Tysons Corner, VA, Dec. 3-4, 1979. 391-400. CONF-791232.

$1360 \mathrm{~m}$ Edie, D.D. and S.S. Melsheimer and J.C. Mullins.

1979 A Direct-contact heat transfer system for phase change energy storage.

Proceedings of Solar Energy Storage Options, San Antonio, TX, March 19-20. 1:455-464. CONF-790328-P2. 
997 Edin, R.E. and D.A. Shaw.

1972 A New concept in electrical process heat.

IEEE Transactions on Industry Applications IA-8(5):559-564.

332 Edward $E$. Johnson, Inc.

1965 Maintaining the yield of water wells. Johnson Drillers Journal 37(1):1-4.

104 Edwards, A.L.

1972 TRUMP: A Computer Program for Transient and Steady- State

Temperature Distributions in Multidimensional Systems.

Lawrence Livermore Laboratory, Livermore, CA. 258 pp. UCRL-14754.

1899 Edwards, D.T.

1981 Assessments of energy storage for solar applications.

Technical and Economic Analys is Meeting, Chicago, April 22.

682 Edwards, J.H.

1974 Engineering design of drilling operations.

Spring Meeting Southern District, API Div. 39-55.

605 Eggers, D.E.

1973 Downward Continuation and Transformation of Potential Fields with Application to Marine Magnetic Anomalies.

M.S.Thesis, Oregon State University. $64 \mathrm{pp}$.

1782 Eilers, L.H. and R.L. Root.

1976 Long-term effects of high temperature on strength retrogression of cements.

46th Annual California Regional Meeting of SPE of AIME, Long Beach, Apri1 8-9. SPE 5871.

105 Einarsson, S.S., A. Vides, and G. Cuellar.

1975 Disposal of geothermal waste water by reinjection.

Proceedings of the Second U.N. Symposium on the Development and Use of Geothermal Resources. 2:1349-1363.

1306 Eissenberg, D.M.

1979 The Use of aquifers for seasonal storage of solar energy: an overview.

Proceedings of Solar Energy Storage Options, San Antonio, TX, March 19-20. 1:23-29.

1979 Annual cycle storage for building heating and cooling. Proceedings of Solar Energy Storage Options, San Antonio, TX, March 19-20. 2:29-70.

811 Eissenberg, D.M. and H.W. Hoffman.

1979 Low-Temperature Energy Storage Program: Progress Report for Period October 1978-March 1979.

Oak Ridge National Laboratory, Oak Ridge, TN. 35 pp.

ORNL/TM-6936. 
1178 Eissenberg, D.M. and H.W. Hoffman.

1979 Low-Temperature Thermal Energy Storage Program Annual Operating Plan, FY-1979.

Oak Ridge National Laboratory, Oak Ridge, TN. 67 pp. ORNL/TM-6934.

998 Ekroth, I.A.

1979 Thermodynamic Evaluation of Heat Pumps Working with High Temperatures. American Chemical Society, Washington, DC. 1713-1719.

1428 Elder, W.J.

1967 Steady free convection in a porous medium heated from below. Journal of Fluid Mechanics 27(1):29-48.

1967 Transient convection in a porous medium. Journal of Fluid Mechanics 27(3):609-623.

907 Electric Information Publications.

1971 Heat pump study report traces major design advances. Electric Comfort Conditioning Journal Nov:19-21.

1553 Electric Power Research Institute, The EPRI Planning Staff.

1979 Overview and Strategy: 1980-1984 Research and Development Program Plan.

Electric Power Research Institute, Palo Alto, CA. PS 1141 SR.

1357 Electric Power Research Institute.

1979 Research Results and Applications.

Electric Power Research Institute, Palo Alto, CA. PS 1196 SR.

1540

1980 Conservation: DOE's High-Priority Program.

EPRI Journal May:30-35.

1555

1980 1980-1984 Research and Development Program Plan: Program Descriptions.

Electric Power Research Institute, Palo Alto, CA. 534 pp. EPRI P-1309-SR.

19801980 Research and Development Program Plan.

Electric Power Research Institute, Palo Alto, CA. 356 pp. EPRI P-1310-SR.

1980 Overview and Strategy: 1981-1985 Research and Development Program Plan.

Electric Power Research Institute, The EPRI Policy Planning Division. $242 \mathrm{pp}$. 
1891 Electric Power Research Institute.

1977 Energy Storage: User Needs and Technology Applications. Energy Research and Development Administration, Washington. 429 pp.

1057 Electrical World.

1975 Thermal storage systems aid load factor. Electrical World $184(4): 56-57$.

175 Electrical World.

1973 Heat pump reliability shows big gains. Electrical World 180(3):78-80.

1373 Elkins, L.F.

1953 Reservoir performance and well spacing: Spraberry Trend Area Field of West Texas. Petroleum Transactions, AIME 198:177-196.

106 Ellenberger, F.R., A.B. Hubbard, W.R. Foote, F. Burggraf, J.J. Martin and N.J. Bloomfield.

1950 Evaluating heat pump performance. ASHRAE Transactions 56(1382):87-106.

999 Elliott, J.F.

1975 Energy for steel production: prospects and options. Energy: Use and Conservation in the Metals Industry, Symposium 104th AIME Annual Meeting, New York. 1-17.

1909 Elliott, R.C., R.F. McAlevy, P.C. Symons, S.H. Nelson, H.N. Seiger and W.W. Walsh.

1981 Cost-effective goals for battery research. Technical and Economic Analysis Meeting, Chicago, April 22.

1646 Ellis, A.J. and W.A.J. Mahon.

1977 Chemistry and Geothermal Systems. Academic Press, New York. 392 pp. ISBN 0-12-237450-9.

1605 Energy Systems, Inc.

1980 Kotzebue Geothermal Project: Analys is of Currently Available Information and Report of Advisory Group Meeting.

Energy Systems, Inc., Anchorage, AK. 49 pp. ESI-Alaska DEPD BRU 08-71-1-500.

1647 Energy User News.

1980 Aquifer thermal storage of waste energy studied. Energy User News 5(39):12.

1786

1980 University seeks energy independence. Energy User News 5(51):6. 
1000 Engelke, C.E.

1978 A Self-contained community energy system.

The Bulletin Nov:51-53.

1458

Economically Competitive Fuel Conservation by Integrated District Heating, Cooling and Electric Power Supply Systems Exploiting Interseasonal Thermal Storage.

The City University of New York, Department of Physics and Astronomy, N.Y. $25 \mathrm{pp}$.

107 Engen, I.A.

1978 Residential Space Heating Cost: Geothermal vs Conventional Systems.

EG and $G$, Idaho, Inc. 41 pp. TREE-1182.

274 Erickson, G.M.

1976 Short, large diameter screens prove effective. Johnson Drillers Journal 48(6):3.

1509 Erikson, R.L., J.A. Stottlemyre and R.P. Smith.

1980 An Experimental Study of the Response of the Galesville Sandstone to Simulated CAES Conditions.

Pacific Northwest Laboratory, Battelle, Richland, WA. 33+ pp. PNL-3399, UC-94e.

1352 Erikson, R.L., and K.M. Krupka.

1980 Thermal Property Measurements of Pomona Basalt from Coreholes DB5 and DB15, Hanford Reservation, Southeastern Washington. Pacific Northwest Laboratory, Battelle, Richland, WA. 30 pp. (Draft).

1080 Ervin, G.

1975 Solar heat storage based on inorganic chemical reactions. Solar Use Now a Resource for People: International Solar Energy Society Conference.

1566 Esbensen, T.V. and V. Korsgaard.

1975 Dimensioning of the Heat Balance and the Solar Heating System in the Zero Energy House in Denmark.

Technical University of Denmark, Thermal Insulation Laboratory, Lyngby, Denmark. 23 pp.

114 Esmail, 0.J. and 0.K. Kimbler.

1967 Investigation of the technical feasibility of storing fresh water in saline aquifers.

Water Resources Research 3(3):683-695.

9999bx Esterka, F. and 0. Slama.

1974 Inhibitor of Swelling and Hydration of Clay Rocks. Czech. 800315, Patent \# 182381, Application \#74/5089. 
115 Faust, C.R. and J.W. Mercer.

1977 Finite-Difference Model of Two-Dimensional, Single, and Two-Phase Heat Transport in a Porous Medium: Version 1. U.S. Geological Survey, Arlington. $84 \mathrm{pp}$. Open File Report $77-234$.

812

1979 Geothermal reservoir simulation: 1. mathematical models for liquid- and vapor-dominated hydrothermal systems. Water Resources Research 15(1):23-30.

813

1979 Geothermal reservoir simulation: 2. numerical solution techniques for liquid- and vapor-dominated hydrothermal systems. Water Resources Research 15(1):31-45.

1976 An Analysis of Finite-Difference and Finite-Element Techniques for Geothermal Reservoir Simulation. Society of Petroleum Engineers of AIME, Dallas. 337-354. SPE -5742 .

1561

1980 Ground-water modeling: numerical models. Ground Water 18(4):395-409.

1563

1980 Ground-water modeling: recent developments.

Ground Water 18(6):569-577.

607 Federal Register.

1978 National Environmental Policy Act: Regulations, Title 40, Chapter 5.

Federal Register 43(230):55978-56007.

613

1978 National Interim Primary Drinking Water Regulations. Codes of Federal Regulations, Title 40, Part 141, pp. 215-230. 40 FR 59565.

1001 Fellows, S.K. and H.P. Rothbaum.

1977 Industrial brine production using power station waste heat to assist solar evaporation of sea water. Journal of Applied Chemical Biotechnology 27:585-695.

896 Felsenthal, M. and F.J. Gangle.

1975 A Case study of thief zones in a California waterflood. Journal of Petroleum Technology 27:1385-1391.

116 Fenske, P.R.

1977 Radial flow with discharging-well and observation-we11 storage. Journal of Hydrology 32(1-2):87-96. 
117 Fenske, P.R.

1977 Type curves for recovery of a discharging well with storage. Journal of Hydrology 33(3-4):341-348.

1888 Ferarra, A.

1977 Thermal Energy Storage Heat Exchanger: Molten Salt Heat Exchanger Design for Utility Power Plants, Final Report. Grumman Aerospace Corporation. 207 pp. (Microfiche).

1002 Fernandes, R.A., 0.D. Gildersleeve and T.R. Schneider.

1974 Assessment of advanced concepts in energy storage and their application on electric utility systems.

Proceedings of the 9th World Energy Conference. 7:281-301.

897 Ferris, J.G., D.B. Knowles, R.H. Brown, and R.W. Stallman.

1962 Theory of Aquifer Tests: Ground-Water Hydraulics.

U.S. Geological Survey, Arlington. $174 \mathrm{pp}$. Water-Supply Paper $1536-\mathrm{E}$.

1482cs Feurer, D.A.

1980 Impact of public utility regulation on district heating. Energy to the 21st Century: 15th Intersociety Energy Conversion Engineering Conference, Seattle, WA, August 18-22. 1:591-599.

1471 Finn, L.

1979 A Swedish Solar Heating Plant with Seasonal Storage; the Ingelstad Project - Design and Construction Stage.

Swedish Council for Building Research, Stockholm, Sweden. 73 pp.

9999ea Fischer, L.S., C.W.J. VanKoppen, J.J. Puts.

1979 Basic aspects of the seasonal storage of solar heat in the ground.

Sun 2: Proceedings of the International Solar Energy Society

Silver Jubilee Congress, Atlanta, GA, May 1979. 1:609-613.

9999dj Fishman, M.J. and E. Brown.

1976 Selected Methods of the U.S.G.S. for the Analysis of Wastewaters. U.S. Geological Survey, Arlington. Open-File Report 76-177.

1129 Flemings, M.C., R.S. Busk, W.A. Barnes, and J.P. Clark (eds.).

1977 Report from International Conference on Energy Conservation in Production and Utilization of Magnesium.

Massachusettes Inst. of Technology, U.S. Energy Reasearch and

Development Adm. and International Magnesium Assoc. 189 pp.

1821 Fletcher, E.A.

1979 Solar energy storage as hydrogen and bromine from hydrogen bromide.

Energy $4: 61-66$. 
898 Flewitt, W.E.

1976 Refined reservoir description maximizes petroleum recovery. $0 i 1$ and Gas Journal 74(1):111-116.

1444 Flower, J.E.

1978 Analytical Modeling of Heat Pump Units as a Design Aid for Performance Prediction. MS Thesis, University of California, Lawrence Livermore Laboratory, Livermore. 144 pp. UCRL-52618.

899 Ford, W.0., Jr. and W.F.N. Kelldorf.

1976 Field results of a short-setting-time polymer placement technique.

Journal of Petroleum Technology 28:749-756.

$1582 \mathrm{ac}$ Fossum, A.F.

1980 Laboratory studies of hard rock for CAES. Mechanical, Magnetic, and Underground Energy Storage 1980 Annual Contractors' Review. pp. 213-219. CONF-801128.

1822 Fowler, J.M.

1978 Energy storage technology. AWARE Magazine Jun:11-15.

118 Fox, E.C. and J.F. Thomas.

1979 A Preliminary Economic Analys is of Aquifer Winter-Chill Storage at the John F. Kennedy Airport.

Oak Ridge National Laboratory, Oak Ridge, TN. ORNL/TM-6876. 30 pp. (Draft).

1179 Foxworthy, B.L.

1979 Summary Appraisals of the Nation's Ground-Water Resources:

Pacific Northwest Region.

U.S. Geological Survey, Arlington. 39 pp. Professional Paper 813-S.

1339

1970 Hydrologic Conditions and Artificial Recharge Through a Well in the Salem Heights Area of Salem, Oregon.

U.S. Geological Survey, Arlington. $56 \mathrm{pp}$. Water-Supply Paper $1594-\mathrm{F}$.

881 Foxworthy, B.L. and C.T. Bryant.

1967 Artificial Recharge Through a Well Tapping Basalt Aquifers at The Dalles, OR.

U.S. Geological Survey, Arlington. 163 pp. Water-Supply Paper $1584-E$.

1003 Fraas, A.P. and G. Samuels.

1978 Power conversion systems of the twenty-first century. Proceedings of the American Society of Civil Engineers, $104(P 01): 83-97$. 
814 Franco, A.

1978 Miniplants speed projects: slash costs. $0 i 1$ and Gas Journal 76(19):167-170.

815

1976 Thermal work humming in Venezuela.

$0 i 1$ and Gas Journal 74(14):132-138.

1004 Fraser, M.D., J.F. Henry, L.C. Borghi and N.J. Barbera.

1979 Analysis of the Photosynthesis Energy Factory as an Integrated Bioconversion System. American Chemical Society, Washington, DC. 279-284.

683 Freedman, S.I. and J.C. Dudley.

1972 Off-Peak Air Conditioning Using Thermal Energy Storage. University of Pennsylvania. 34 pp. PB-238 105.

1005 French, E.P.

1979 Hybrid Thermal Storage Subroutine for Transient Simulation. American Chemical Society, Washington, DC. 516-520.

1370 Friedman, M.

1976 Porosity, permeability, and rock mechanics: a review.

17 th Symposium on Rock Mechanics, Session 2A. 2A1-1-2A1-16.

1770 Frind, E.0.

1979 Exact aquitard response functions for multiple aquifer mechanics. Advances in Water Resources 2(2):77-82.

1006 Frysinger, G.R.

1979 Storage Assisted Heat Pumps Using Phase Change Materials. American Chemical Society, Washington, DC. 1730-1733.

1456

1980 Life and Stability Testing of Packaged Low-Cost Energy Storage Materials.

Oak Ridge National Laboratory, Oak Ridge, TN. $116 \mathrm{pp.}$ ORNL/Sub-7585/1.

1007 Fuchs, W., G.R. James, K.J. Stokes.

1977 Economics of flue gas heat recovery.

Chemical Engineering Progress 73(11):65-70.

1347 Fugro, Inc. and Washington State University.

1980 Site Identification for Aquifer Thermal Energy Storage Program, Bellingham, Washington: Final Technical Report.

Fugro, Inc. 34 pp. (Draft).

1862 Fujii, I. and K. Tsuchiya.

Experimental study of thermal energy storage by use of reversible chemical reactions.

Alternative Energy Sources: an International Compedium, Volume 
9-Energy Delivery, Conservation and Environment 9:4021-4035.

119 Fulford, R.S.

1968 Effects of brine concentration and pressure drop on gypsum sealing in oil wells.

Journal of Petroleum Technology 20:559-564.

1177 r Fulton, R.L.

1978 Developments in direct-contact heat exchange.

Pages 55-56 in Earth Science Division Annual Report, Lawrence Berkeley Laboratory, Berkeley, CA. LBL-8648.

1065 Funnel1, J.E. and E.J. Wolfe.

1974 Utilization of power-plant heat. Combustion May: $4-10$.

1355 Furman, E.R.

1979 Candidate thermal energy storage technologies for solar industrial process heat applications. Solar Industrial Process Heat Conference, October 31 - November 2 , 1979. DOE/NASA/1034-79/6.

120 Gabrysch, R.K. and C.W. Bonnet.

1976 Land-Surface Subsidence at Seabrook, Texas. U.S. Geological Survey, Arlington. 53 pp. Water Resources Investigations 76-31. AD-A035 621 .

1008 Gajanana, B.C., H.L. Brown, and B.B. Hamel.

1979 Operational Optimization of an HVAC System Coupled with a Multi-Tank Thermal Storage.

American Chemical Society, Washington, DC. 500-506.

1313 Galley, J.E. (ed).

1968 Subsurface Disposal in Geologic Basins: A Study of Reservoir Strata. American Association of Petroleum Geologists, Tulsa, OK. 253 pp.

1783 Gallus, J.P., D.E. Pyle and L.K. Moran.

1979 Physical and Chemical Properties of Cement Exposed to Geothermal Dry Steam.

Socity of Petroleum Engineers of AIME, New York. 6 pp. SPE 7876.

1177m. Gamble, T.D., W.M. Goubau, N.E. Goldstein and J. Clarke.

1978 Magnetotelluric survey at Cerro Prieto. Pages 41-43 in Earth Science Division Annual Report, Lawrence Berke ley Laboratory, Berkeley, CA. LBL-8648.

121 Gambolati, G.

1977 Deviations from the Theis solution in aquifers undergoing three-dimensional consolidation.

Water Resources Research 13(1):62-68. 
276 Gambolati, G., P. Gatto, and R.A. Freeze.

1974 Mathematical simulations of the subsidence of Venice: 2. Results. Water Resources Research 10(3):563-577.

1698 Gambolati, G. and R.A. Freeze.

1973 Mathematical simulation of the subsidence of Venice. Water Resources Research 9(3):721-733.

122 Gannon, R.

1978 Ground-water heat pumps: home heating and cooling from your own well. Popular Science Feb:78-82.

1420 Garcia-Bengochea, J.I. and R.0. Vernon.

1970 Deep well disposal of waste waters in saline aquifers of South Florida. Water Resources Research 6(5):1454-1470.

1082 Garton, R.R. and A.G. Christianson.

1970 Beneficial uses of heat: an evaluation. Conference on Beneficial Uses of Thermal Discharges, Albany, NY, Sept. $18.6 \mathrm{pp}$.

606 Garza, S.

1977 Artificial Recharge for Subsidence Abatement at the NASA-Johnson Space Center.

U.S. Geological Survey, Arlington. 82 pp. Open File Report $77-219$.

123 Gass, T.E.

1976 Ground water flow in unconsolidated formations. Water Wel1 Journal 30(10):22-23.

1977 Don't let the bugs get the best of you. Water Well Journal 32(1):26-27.

1977 Energy development and its effect on ground water. Water We11 Journal 31(4):34-35.

1977 Land subsidence. Water Well Journal 31(5):30-31.

1977 Part I : well development. Water Well Journal 31(4):40-42.

128 Gass, T.E. and J.H. Lehr.

1977 Ground-water energy and the ground-water heat pump. Water Well Journal 31(4):42-47. 
129 Gass, T.E. and J.H. Lehr.

1977 Ground-water energy and the ground-water source heat pump. Ground Water 15(3):244-249.

130 Gates, C.F. and B.G. Holmes.

1967 Thermal well completions and operations.

Proceedings of the Seventh World Petroleum Congress. 3:419-429.

816 Gates, G.L. and C.F. Parent.

1976 Water-quality control presents challenge in giant Wilmington

Field.

$0 i 1$ and Gas Journal 74(33):115-125.

1130 Gatts, R.R., R.G. Massey, and J.C. Robertson.

1974 Energy Conservation Program Guide for Industry and Commerce. U.S. Dept. of Commerce, National Bureau of Standards, Washington, DC. NBS Handbook No. 115.

$1544 m$ Gay, B.M., H. Palmour and R.L. Cochrane.

1980 01ivine-based heat storage refractories. Proceedings of the DOE Thermal and Chemical Storage Annual Contractors' Meeting. 46-50.

131 Geertsma, J.

1973 Land subsidence above compacting $0 i 1$ and gas reservoirs. Journal of Petroleum Technology 25:734-744.

1587 Gelhar, L.W., A.L. Gutjahr and R.L. Naff.

1979 Stochastic analysis of macrodispersion in a stratified aquifer. Water Resources Research 15(6):1387-1397.

1757 Gelhar, L.W., J.L. Wilson, A.L Gutjahr.

1979 Comments on "simulation of groundwater flow and mass transport under uncertainty" by D.H. Tang and G.F. Pinder. Advances in Water Research 2(2):101.

817 Geological Society of America.

1976 Program: 1976 Annual Meeting. Geological Society of America. pp. 1148-1149.

818 George, C.J. and L.H. Stiles.

1978 Improved techniques for evaluating carbonate waterfloods in West Texas.

Journal of Petroleum Technology 30:1547-1554.

1578 Geothermal Resources Council.

1979 Expanding the Geothermal Frontier: Geothermal Resources Council Annual Meeting, Reno, NV, September 24-27.

Geothermal Resources Council Transactions 3:1-808. 
1579 Geothermal Resources Council.

1978 Geothermal Energy: a Novelty Becomes Resource, Geothermal

Resources Council Annual Meeting, Hilo, HI, July 25-27.

Geothermal Resources Council Transactions 2:1-748.

1618 Geraghty, J.J., D.W. Miller, R. Van der Leeden, F.L. Troise.

1973 Water Atlas of the United States.

Water Information Center, Port Washington, NY. 122 pp.

684 Getzen, R.T.

1977 Analog-Model Analysis of Regional Three-Dimensional Flow in the Ground-Water Reservoir of Long Island, NY.

U.S. Geological Survey, Arlington. 49 pp. Professional Paper 982.

9999dz Ghaffari, A.

1980 Model for Predicting Thermal Conductivity of Rock-Fluid Systems. California University, College of Engineering, Berkeley, CA. 143 pp. LBL -11384 .

133 Gibb, J.P. and E.W. Sanderson.

1969 Cost of Municipal and Industrial Wells in Illinois, 1964-1966. Illinois State Water Survey. 22 pp. Circular 98.

$1544 \mathrm{j}$ Giese, R.F.

1980 Distributed thermal energy storage in the residential sector: commercialization readiness assessment and implementation strategy.

Proceedings of the DOE Thermal and Chemical Storage Annual Contractors' Review Meeting. 37-38.

134 Gill, M.A.

1975 Iterative method of determining aquifer constants. Journal of the Irrigation and Drainage Division ASCE 101 ( IR1) : $81-85$.

608 Gillespie, J.B., G.D. Hargadine, and M.J. Stough.

1977 Artificial-Recharge Experiments Near Lakin, Western Kansas. Kansas Water Resources Board, Topeka, KS. 91 pp. Bulletin 20.

901 Gilliland, H.E. and F.R. Conley.

1976 Pilot flood mobilizes residual oil. $0 i 1$ and Gas Journal 74(3):43-48.

135 Givoni, B.

1977 Underground longterm storage of solar energy: an overview. Solar Energy 19:617-623.

1979 Store energy in the ground. Chemtech 9(6):384-390. 
686 Glasby, G.P.

1969 Minerals from the sea.

Endeavor 3(2):82-85.

1613 Glaser, C.W.

1977 Heat Pumps Without Supplemental Heat. Union Electric Company, Special Projects Division, St. Louis, M0. $402-408$.

136 Gleason, V.E.

1978 The Legalization of ground-water storage. Water Resources Bullet in 14(3):532-541.

688 Glenn, D.R.

1979 Industrial Applications of Thermal Energy Storage.

Institute of Gas Technology, Chicago. 23 pp. CONF 790107-9.

1083 Glenn, D.R., R.L. McCarthy, and J.D. Schelkopf.

1976 Industrial energy conservation through integration of thermal energy storage into process energy dynamics.

11th Intersociety Energy Conversion Engineering Conference. $1: 623-627$.

1241 Glenn, E.E., M.L. Slusser, and J.L. Huitt.

1957 Factors affecting productivity: 1. drilling fluid filtration. Petroleum Transactions, AIME, 241:126-139.

687 Glenn, E.E. and M.L. Slusser.

1957 Factors affecting well productivity: 2. drilling fluid particle invasion into porous media.

Petroleum Transactions, AIME, 210:132-139.

137 Glover, R.E. and W.T. Moody.

1976 Drawdown due to pumping in an anisotropic aquifer. Water Resources Bulletin 12(5):941-950.

1836 Godfrey, R.D. and S.A. Mumma.

1976 Thermal Performance of Paraffin Phase Change Materials Dispersed in a Concrete Mortar Filler Matrix.

The American Society of Mechanical Engineers, New York. 4 pp. 76-WA/HT-33.

902 Gogarty, W.B.

1976 Status of surfactant or micellar methods. Journal of Petroleum Technology 28:93-102.

1544w Goldenberg, D.

1980 Thermal energy storage for residential energy conservation. Proceedings of the DOE Thermal and Chemical Storage Annual Contractors' Review Meeting. 82-86. 
1177h Goldstein, N.E., H.A. Wollenberg, H. Bowman and E. Mozley.

1978 Mt. Hood geothermal resource evaluation. Pages 23-25 in Earth Sciences Division Annual Report, Lawrence Berkeley Laboratory, Berkeley, CA. LBL-8648.

609 Goldstein, N.E., R.A. Norris, and M.J. Wilt. Assessment of Surface Geophysical Methods in Geothermal Exploration and Recommendations for Future Research. Lawrence Berkeley Laboratory, Earth Sciences Division, Berkeley, CA. 163 pp. LBL-6815.

689 Golibersuch, D.C. and K.S. Vosburgh.

1976 Peaking and Storage Activities in West Germany. General Electric Company, Corporate Research and Development, Energy Sciences Branch. $17 \mathrm{pp}$.

139 Goranson, C.B., R.C. Schroeder, and J.P. Haney.

1979 Evaluation of Coso Geothermal Exploratory Hole No. 1 (CGEH-1), Coso Hot Springs: KGRA, China Lake, California. Lawrence Berkeley Laboratory, Berkeley, CA. 14 pp. LBL -8675.

138 Goranson, C.B. and R.C. Schroeder.

1979 Site Specific Geothermal Reservoir Engineering Activities at Lawrence Berkeley Laboratory. Lawrence Berkeley Laboratory, Berkeley, CA. 4 pp. LBL-9463.

1009 Gordon, L.H.

1979 Thermal Storage Technologies for Solar Industrial Process Heat Applications. National Aeronautics and Space Administration, Lewis Research Center. $16 \mathrm{pp}$.

1837

Thermal Storage Technologies for Solar Industrial Process Heat Applications.

NASA Lewis Research Center. 16 pp.

1010 Gorzelnik, E.F.

1978 How to recycle low-grade process heat. Electrical World 190(3):60-61.

1828 Government Institutes, Inc.

1978 Need for large-scale thermal energy storage. Energy Technology V: Challenges to Technology, Proceedings of the 5th Energy Technology Conf., Washington, Feb 27. 177-188.

280 Govier, G.W.

1976 Enhanced recovery in Alberta: a review and the role of the Energy Resources Conservation Board. Journal of Canadian Petroleum Technology 15(3):13-19. 
140 Goyal, K.P. and D.R. Kassoy.

1979 Fault Zone Controlled Charging of a Liquid Dominated Geothermal Reservoir. Lawrence Berkeley Laboratory, Berkeley, CA. 34 pp. LBL-9237. (Preprint).

141

1979 Heat and Mass Transfer in a Saturated Porous Wedge with Impermeable Boundaries. Lawrence Berkeley Laboratory, Berkeley, CA. 40 pp. LBL-9328. (Preprint).

690

1978 Heat and Mass Transfer Studies of the East Mesa Anomaly.

Lawrence Berkeley Laboratory, Berkeley, CA. 9 pp. LBL-9330.

1644 Gozeinik, E.F.

1980 Customers give thermal storage a big ok. Electrical World 193(5):56-58.

1838 Grange, B.W., R. Viskanta and W.H. Stevenson.

1976 Diffusion of heat and solute during freezing of salt solutions. International Journal of Heat and Mass Transfer 19:373-384.

$1177 n$ Granne11, R.B., D.W. Tarman and N.E. Goldstein.

1978 Precision gravity surveys at Cerro Prieto.

Pages 43-45 in Earth Science Division Annual Report, Lawrence Berkeley Laboratory, Berkeley, CA. LBL-8648.

142 Grantham, C.K. and J.P. Sloan.

1975 Toxicity study: drilling fluid chemicals on aquatic life. pp. 103-112 in Environmental Aspects of Chemical Use in We11-Dri11ing Operations, U.S. EPA. EPA-560/1-75-004.

143 Gray, G.R.

1973 New muds designed to improve drilling rate, hole stability. World 0 il 176(6):84-86.

144 Gray, W.G. and K. O'Neil1.

1976 On the general equations for flow in porous media and their reduction to Darcy's Law. Water Resources Research 12(2):148-154.

146 Green, D.W.

1963 Heat Transfer with a Flowing Fluid Through Porous Media. PhD Thesis, University of Oklahoma. $251 \mathrm{pp}$.

691 Green, J.H.

1964 The Effect of Artesian Pressure Decline on Confined Aquifer Systems and its Relation to Land Subsidence.

U.S. Geological Survey, Arlington. 11 pp. Water-Supply Paper 1779-T. 
1183 Green, J.H.

1962 Compaction of the aquifer system and land subsidence in the Santa Clara Valley, CA.

Paper 450-D, pp. 175-178 in U.S.G.S. Research, Short Papers in Geology, Hydrology, and Topography, Articles 120-179, U.S.G.S.

147 Green, M.A., H.S. Pines, W.L. Pope, and J.D. Williams.

1977 Thermodynamic and Cost Optimization Using Program GEOTHM. Lawrence Berkeley Laboratory, Berkeley, CA. 4 pp. LBL-6303.

1360n Green, N.D., W. Keith and R. Watson.

1979 An Immiscible fluid, phase change, heat storage battery. Proceedings of Solar Energy Storage Options, San Antonio, TX, March 19-20. 1:465-472. CONF-790328-P2.

1482 ct Greenberg, J.S.

1980 A Financial risk analysis of a district heating business venture. Energy to the 21st Century: 15th Intersociety Energy Conversion Engineering Conference, Seattle, WA, August 18-22. 1:600-608.

1733 Greenberg, M. and A.J. Van den Berg.

1974 An Analytical Method for Determining Heat Transfer from Power Plant Coolant in the Florida "Boulder Zone". U.S. Army Facilities Engineering Support Agency, Research and Technology Division. $35 \mathrm{pp}$. RT-1010.

145 Gregg, D.0. and K.G. Kennedy.

1975 Movement of chemical contaminants in ground water. pp. 289-309 in Environmental Aspects of Chemical Use in Well Drilling Operations. U.S. EPA. EPA-560/1-75-004.

1011 Gregory, M.W., H. Shaw, R.S. Reed and A. DeCagna.

1979 Industrial Applications of Warm Water. American Chemical Society, Washington, DC. 1618-1624.

692 Gresko, T.M. and D.R. Glenn.

1976 Thermal energy storage applied to residential heating systems. 11 th Intersociety Energy Conversion Engineering Conference. $1: 591-597$.

693 Gring, L.M. and B.H. Caudle.

1972 A Visual Study of Water Flooding a Microlayered Sandstone. Society of Petroleum Engineers of AIME, Dallas. 8 pp. SPE-4106. (Preprint).

694 Gringarten, A.C., A. Landreau, M.J. Lienhardt and P. Peaudecerf.

1976 Etude des Possibilites de Stockage D'eau Chaude en Provenance de Centrales Thermiques.

Bureau de Recherches Geologiques et Minieres, Orleans Cedex. 76 SGN 389 AME. 
279 Gringarten, A.C. and H.J. Ramey, Jr.

1974 Unsteady-state pressure distributions created by a well with a single infinite-conductivity vertical fracture.

Society of Petroleum Engineers Journal 257:347-360.

148 Gringarten, A.C. and J.P. Sauty.

1975 A Theoretical study of heat extraction from aquifers with uniform regional flow.

Journal of Geophysical Research 80(35):4956-4962.

1975 Simulation des transferts de chaleur dans les aquiferes. Bulletin B.R.G.M., 3(1):25-34.

278 Grist, D.M., G.0. Langley, and E.L. Neustadter.

1975 The Dependence of water permeability on core cleaning methods in the case of some sandstone samples. Journal of Canadian Petroleum 14(2):48-52.

1544ad Gross, R.J. and R.W. Harrigan.

1980 Status report of thermocline thermal energy storage studies at Sandia National Laboratories.

Proceedings of the DOE Thermal and Chemical Storage Annual Contractors' Review Meeting. 113-117.

192 Ground Water Age.

1979 House on ice.

Ground Water Age 13(9):16-19.

1402

1980 New nationwide hydrologic investigations. Ground Water Age 14(7):21-42.

1371 Grove, D.B., W.A. Beetem and F.B. Sower.

1970 Fluid travel time between a recharging and discharging well pair in an aquifer having a uniform regional flow field. Water Resources Research 6(5):1404-1410.

1753 Grubaugh, E.K. and D.L. Reddell.

1980 Heat Transport in Groundwater Systems: Volume 1, Finite Element Model.

Texas A\&M University, Texas Water Resources Institute. 180 pp. TR-104.

1878 Gruen, D.M., M. Mendelsohn, I. Sheft and G. Lamich.

1978 Status Report on the HYCSOS Chemical Heat Pump and Energy Conversion System.

Argonne National Laboratory, Argonne, IL. 12 pp. CONF-781142-7. (Microfiche).

1084 Gruen, D.M., R.L. McBeth, M. Mendelsohn, J.M. Nixon, F. Schreiner, and I. Sheft. 
1976 HYCSOS: a solar heating cooling and energy conversion system based on metal hydrides [1].

11th Intersociety Energy Conversion Engineering Conference. $1: 681-687$.

$1453 f$ Guenther, K.L.

1979 Operating principles and applications of Vortex shedding meters. Official Proceedings, 70th Annual Conference of the International District Heating Assn. June 18-20. Section 11.

150 Guest, R.J. and C.W. Zimmerman.

1973 Compensated gamma ray densimeter measures slurry densities in flow. Petroleum Engineer 45(10):80-87.

1697 Guha, T.K., J.A. Fleniken, K.E. Davis and R.E. Collins.

1978 Role of silica in geothermal storage.

The University of Houston, Houston. $10 \mathrm{pp}$.

151 Guha, T.K., K.E. Davis, R.E. Collins, J.R. Fanchi and A.C. Meyers.

1977 Manmade geothermal energy.

pp. 2641-2654 in T.N. Verziroglu, Alternative Energy Sources and Int'l Compendium, Vol 6. Hemisphere Publishing Co, Washington.

1244 Gunn, T.L.

1978 The Energy Optimal Use of Waste Paper: Final Report. University of Illinois, Office of Vice Chancellor for Research, Urbana, IL. 177 pp. CO0-2893-9.

153 Gupta, S.K., K.K. Tanji, and J.N. Luthin.

1975 A Three-Dimensional Finite Element Ground Water Model. California Water Resources Center, University of California, Davis. 153 pp. UCAL-WRC-C-152.

1544a Gurevich, M.

1980 Overview of the Thermal Energy Storage (TES) Program. Proceedings of the DOE Thermal and Chemical Storage Annual Contractors' Review Meeting. 1-2.

695 Gustafson, G.

1977 A Method for calculating the hydraulic properties of leaky aquifer systems.

Noric Hydrology 8(2):65-82.

1314 Guyer, E.C., J.G. Bourne, L. Paglia and D.H. Walker.

1978 Rock Bed Storage for Cooling: Final Report.

Dynatech R/D Co. Cambridge. 176 pp. C00-4481-1.

277 Guyer, E.C. and M.W. Golay.

1977 Evaluation of Combined Thermal Storage Pond/Dry Cooling Tower Waste Disposal Systems.

American Sociey of Mechanical Engineers, New York. 9 pp. 77-HT-57. 
1012 Gwyther, D.N.

1976 Waste heat recovery in the drop forging industry. Metallurgia and Metal Forming 43(6):162-167.

13600 Haas, W.R., F.A. Jaeger and M.T. Howerton.

1979 Thermochemical energy storage and heat pump system using ammoniated salts.

Proceedings of Solar Energy Storage Options, San Antonio, TX, March 19-20. 1:473-488. CONF-790328-P2.

1350 Hackett, C.E.

1979 Comparative Analysis of Solar Energy Storage Cycles. Sandia Laboratories, Albuquerque, NM. 23 pp. CONF-790954-1.

154 Hadley, W.A. and R. Eisenstadt.

1955 Thermally actuated moisture migration in granular media. Transactions, American Geophysical Union 36(4):615-623.

155 Halevy, E. and A. Nir.

1962 The Determination of aquifer parameters with the aid of radioactive tracers. Journal of Geophysical Research 67(6):2403-2409.

1013 Hall, E.H. and J.A. Eibling.

1977 Characterization of industrial process heat: including the potential for solar or nuclear systems to supply this market. ANS Transactions 27:2. (Abstract).

1664 Ha11, E.W., W. Hausz, R. Anand, N. LaMarche, J. Oplinger and M. Katzer.

1979 Conceptual Design of Thermal Energy Storage Systems for Near Term Utility Applications. General Electric Co. DOE/NASA/0012-79/2.

1839 Hal1, R.C.

1964 The Use of latent energy of vaporization in energy reservoirs. Solar Energy 8(3):99-102.

1478 Hampe 1, V.E.

1977 Decision Making with Interactive Access to Integrated Administrative and Technological Data Bases. Lawrence Livermore Laboratory, Livermore, CA. 60pp. UCRL-80353.

1479 Hampe1, V.E., S.K. MCGrogan, L.E. Gal10, and J.E. Swanson. 1979 The LLL "META-MACHINE": a Flexible, Extensible, and Practical Technique for Interactive Data Management, Modeling and Distributed Networking. Lawrence Livermore Laboratory, Livermore, CA. 8 pp. UCRL-83064. (Extended summary-preprint). 
156 Hanck, J.A. and G. Nekoksa.

1975 Corrosion rate monitoring at the Geysers Geothermal Power Plant. Proceedings of the Second U.N. Symposium on the Development and Use of Geothermal Resources. 1980-1984.

1014 Hanna, W.T. and W.J. Frederick, Jr.

1978 Energy conservation in the pulp and paper industries. Chemical Engineering Progress 74(5):71-77.

157 Hansen, V.E.

1952 Complicated well problems solved by the membrane analogy. Transactions, American Geophysical Union 33(6):912-916.

610 Hanson, J.M.

1978 Heat Transfer Effects in Forced Geoheat Recovery Systems. Ph.D. Thesis, Oregon State University, Corvallis. 217 pp. University Microfilms, Ann Arbor, MI. 78-5355.

696 Hanson, M.E., B.K. Crowley, and J.S. Kahn.

1975 Massive Hydraulic Fracturing: Identification of Critical Technical Issues for Application in Increasing Gas Production in the Western United States. Lawrence Livermore Laboratory, Livermore, CA. 24 pp. UCRL 51751.

158 Hantush, M.S.

1961 Drawdown around a partially penetrating well. Journal of the Hydraulics Division ASCE 87(HY4):83-98.

159

1967 Growth and decay of groundwater-mounds in response to uniform percolation. Water Resources Research 3(1):227-234.

281

1967 Flow to wells in aquifers separated by a semipervious layer. Journal of Geophysical Research 72(6):1709-1720.

611

1964 Hydraulics of Wells.

Advances in Hydroscience, Academic Press. Vo1. 1. 432 pp.

697

1961 Economical Spacing of Interfering Wells. International Association of Science Hydrogeology. Pub. 57. 350-364.

160 Hantush, M.S. and C.E. Jacob.

1954 Plane potential flow of ground water with linear leakage. Transactions, American Geophysical Union 35(6):917-936. 
161 Hantush, M.S. and C.E. Jacob.

1955 Non-steady radial flow in an infinite leaky aquifer.

Transactions, American Geophysical Union 36(1):95-100.

162

1960 Flow to an eccentric well in a leaky circular aquifer. Journal of Geophysical Research 65(10):3425-3431.

698 Harboe, H.

1972 Power in 2000 A.D.

Journal of Fuel and Heat Technology 19(3):1-5.

1678 Harbridge House, Inc.

1980 Ground Water and Energy: Proceedings of the U.S. Department of Energy's National Workshop, Albuquerque, NM, January 29-31.

U.S. Deparment of Energy, Asst. Secretary for Environment, Off. of Environmental Assessments, Washington. 183 pp. CONF-800137.

1436 Hardee, J.

1979 Instrumentation of Urban Hydrology Monitoring Sites in Southeast Florida.

U.S. Geological Survey, Arlington. Water Resources Investigation 79-37. $38 \mathrm{pp}$.

163 Harnish, J.R.

1967 Heat pumps: manufacturer's viewpoint. Journal of ASHRAE 9(9):40-41.

959 Harrar, J.E., C.H. Otto, Jr., S.B. Deutscher, R.W. Ryon, and

G.E. Tardiff.

1979 Studies of Brine Chemistry, Precipitation of Solids, and Scale Formation at the Salton Sea Geothermal Field.

Lawrence Livermore Laboratory, Livermore, CA. 17 pp. UCRL-52640.

1324 Harrar, J.E., F.E. Locke, C.H. Otto, Jr., L.E. Lorensen, W.P.

Frey.

1979 On-Line Tests of Organic Additives for the Inhibition of the Precipitation of Silica from Hypersaline Geothermal Brine: Part 2. Lawrence Livermore Laboratory, Livermore, CA. 22 pp. UCID-18195.

905 Harrar, J.E., F.E. Locke, C. Otto, L.E. Lorensen, W.P. Frey and E.0. Sne 11 .

1979 On-Line Tests of Organic Additives for the Inhibition of the Precipitation of Silica from Hypersaline Geothermal Brine: Part 3. Lawrence Livermore Laboratory, Livermore, CA. 31 pp. UCID-18238.

1885 Harris, M.J. and L.J. Wittenberg.

1979 Heat Extraction from a Large, Salt-Gradient Solar Pond. Mound Facility, Miamisburg, OH. 3 pp. MLM-2657(OP). (Microfiche). 
13831 Harrison, T.D. and R.A. Randall.

1980 Thermal storage experience at the MSSTF and plans for the future. Thermal Energy Storage: Fourth Annual Review Meeting, Tysons Corner, VA, Dec. 3-4, 1979. 125-130. CONF-791232.

1500 Hasbrouck, R.T., L.B. Owen and R. Netherton.

1979 Automated System for Membrane Filtration and Core Tests. Lawrence Livermore Laboratory, Livermore, CA. 4 pp. UCRL-83009.

1840 Hatami, R.

1979 Solar Heated Absorption Refrigeration System. American Chemical Society. p 278. Paper No. 799059.

906 Haugen, A.K. and I.L. Purdy.

1976 Coating waterflood supply line stops corrosion and reduces horsepower.

$0 i 1$ and Gas Journal 74(26):148-150.

164 Hausz, W.

1976 Annual storage: a catalyst for conservation. International Total Energy Congress, Copenhagen, Denmark, GE Tempo. 23 pp. P-735.

1974 Heat storage wells. Institute of Gas Technology Symposium: Efficient Use of Fuels in Process and Manufacturing Industries, GE Tempo. 14 pp. P-655.

1974 Heat storage wells conserve fuels. GE Tempo, Santa Barbara, CA. 185-201.

167

1978 The Need for a Heat Storage Well System Model. GE Tempo, Santa Barbara, CA. 3 pp.

1977 Seasonal storage in district heating. District Heating Jul-Aug-Sep:5-11.

1979 Thermal Storage and Transport Briefing Charts. GE Tempo, Santa Barbara, CA.

1979 Combined Thermal Storage and Transport for Utility Applications, Final Report. Electric Power Research Institute, Palo Alto, CA. EPRI-EM 1175.

1980 Thermal energy storage and transport. Thermal Energy Storage: Fourth Annual Review Meeting, Tysons 
Corner, VA, Dec. 3-4. 57-78. CONF-791232.

170 Hausz, W., B.J. Berkowitz and R.C. Hare.

1978 Conceptual Design of Thermal Energy Storage Systems for Near Term Electric Utility Applications: Vol 1, Screening of Concepts. General Electric Company, Schenectady. DOE/NASA/0012-78/1.

1015 Hausz, W., R.K. Anand and N. LaMarche.

1979 Electric Utility Applications of Thermal Energy Storage and Transport.

American Chemical Society, Washington, DC. 467-474.

172 Hausz, W. and C.F. Meyer.

1975 Energy conservation: is the heat storage well the key? Public Utilities Fortnightly 95:34-38.

173

1979 Technical Aspects of Thermal Storage in Aquifers. GE Tempo, Santa Barbara, CA. 26 pp. (Draft).

1874 Hautala, R.R. and. C.R. Kutel.

1978 Development of a Practical Photochemical Energy Storage System: Annual Report. University of Georgia, Athens. 24 pp. SR0-893-14. (Microfiche).

820 Havrilak, R.J.

1976 Energy costs dictate efficient well design. Johnson Drillers Journal 48(6):1-2, 13-15.

1016 Hawkes, D.A. and S.B. Hosegood.

1971 The High Temperature Gas Cooled Reactor: A Process Heat/Electrical Energy Source for a Large Steelworks. Meeting on Alternative Routes to Steel, Hilton Hotel, London.

1579bu Hayashi, M., T. Mimura and T. Yamsaki.

1978 Geological setting of reinjection wells in the otake and the Hatchobaru Geothermal Field, Japan.

Geotherma 1 Resources Councii Transactions 2:263-266.

821 Haynes, C.D. and D.M. Grubbs.

1969 Design and Cost of Liquid Waste Disposal System. University of Alabama, Natural Resources Center, University, AL. $89 \mathrm{pp}$. Report №. 692 .

1393 Healy, J.H., W.W. Rubey, D.T. Griggs and C.B. Raleigh.

1968 The Denver earthquakes. Science 161(3848):1301-1310.

964 Heating, Piping and Air Conditioning.

1950 The Heat pump: heat sources and sinks.

Heating, Piping, and Air Conditioning 22(11):87-91. 
701 Heating and Ventilating News.

1974 Heat pumps.

Heating and Ventilating News 17(12):10-12.

1360 aa Hedden, R.E. and D.E. Cassel.

1979 Economics of hot versus cold water storage for solar cooling. Proceedings of Solar Energy Storage Options, San Antonio, TX, March 19-20. 1:593-602. CONF-790328-P2.

177 Hegelson, H.C. and D.H. Kirkham.

1974 Theoretical prediction of the thermodynamic behavior of aqueous electrolytes at high pressures and temperatures: Part 1. American Journal of Science 274:1089-1198.

1841 Heine, D., F. Heess and M. Groll.

1979 Investigation of the Corrosion and Melting/Freezing Behavior of High Temperature Latent Heat Storage Materials.

American Chemical Society. 459-466. Paper no. 799096.

1443 Heisel, J.E. and J.R. Gonzalez.

1979 Water Budget and Hydraulic Aspects of Artificial Recharge, South Coast of Puerto Rico. U.S. Geological Survey, Arlington. Water Resources Investigation 78-58. $102 \mathrm{pp}$.

178 Heiss, H.W.

1977 Research foundation utilizes ground water heat pumps. Water Well Journal 31(4):58-59.

1017 Heitner, K.L.

1979 Energy storage systems for improved load management. Power Eng ineering Sept:56-59.

1842

1979 Energy storage systems for improved load management. Power Engineering Sept:56-59.

179 Hellstrom, G.

1978 Aquifer storage projects in Sweden. Proceedings of the Thermal Energy Storage in Aquifer Workshop, Lawrence Berkeley Laboratory. 4 pp. CONF-7805140.

1979 Heat Storage in Eskers: A Numerical Study.

Lund Institute of Technology, Department of Mathematical

Physics, Lund, Sweden. 7 pp.

1184 Hellstrom, G., C.F. Tsang, and J. Claesson.

1979 Heat Storage in Aquifers, Buoyancy Flow and Thermal Stratification Problems. Lund University, Department of Mathematical Physics, Lund, Sweden. $70 \mathrm{pp}$. 
1749 Hellstrom, G. and J. Claesson.

1978 Heat Losses and Temperature Fields for Heat Storage Aquifers: a Computational Model with a Simplified Linear Water Flow. Lund Institute of Technology, Department of Mathematical Physics, Lund, Sweden. $37 \mathrm{pp}$.

284 Helm, D.C.

1975 One-dimensional simulation of aquifer system compaction near Pixley, CA: 1. constant parameters. Water Resources Research 2(3):465-478.

180 Helweg, 0.J.

1978 Regional ground-water management. Ground Water 16(5):318-321.

908 Hem, J.D.

1959 Study and Interpretation of the Chemical Characteristics of Natural Water.

U.S. Geological Survey, Arlington. 269 pp. Water-Supply Paper 1473.

1185

1963 Chemical Equilibria and Rates of Manganese 0xidation. U.S. Geological Survey, Arlington. $64 \mathrm{pp}$. Water-Supply Paper $1667-A$.

1964 Deposition and Solution of Manganese 0xides. U.S. Geological Survey, Arlington. 42 pp. Water-Supply Paper $1667-B$.

1965 Reduction and Complexing of Manganese by Gallic Acids. U.S. Geological Survey, Arlington. $28 \mathrm{pp}$. Water-Supply Paper $1667-D$.

1187 Hem, J.D., C.E. Roberson, C.J. Lind, and W.L. Polzer.

1973 Chemical Interactions of Aluminum with Aqueous Silica at $25 \mathrm{C}$. U.S. Geological Survey, Arlington. 57 pp. Water-Supply Paper $1827-E$.

1582s Hendrickson, P.L.

1980 Legal and regulatory issues applicable to aquifer thermal energy storage.

Mechanical, Magnetic, and Underground Energy Storage 1980 Annual Contractors' Review. pp. 35-37. CONF-801128.

1980 Legal and regulatory issues affecting the aquifer thermal energy storage concept.

Pacific Northwest Laboratory, Battelle, Richland, WA. 53 pp. PNL-3437. 
181 Henry, H.R., J.R. McDonald, and R.M. Alverson.

1971 Aquifer Performance Tests Under Two-Phase Flow Conditions. U.S. Department of Interior, Office of Water Resources Research. PB 209535.

822 Herbeck, E.F., R.C. Heintz, and J.R. Hastings.

1976 Fundamentals of tertiary oil recovery: Part 2. LPG miscible slug process.

Petroleum Engineer 48(2):58-66.

823

1976 Fundamentals of tertiary oil recovery: Part 3. enriched gas miscible process.

Petroleum Engineer 48(3):85-88.

824

1976 Fundamentals of tertiary oil recovery: Part 4. high pressure lean gas miscible process.

Petroleum Engineer 48(4):66-72.

825

1976 Fundamentals of tertiary oil recovery: Part 5. carbon dioxide miscible process.

Petroleum Engineer 48(5):114-119.

182 Hermannsson, S.

1970 Corrosion of metals and the forming of a protective coating on the inside of pipes carrying thermal waters used by the

Reykjavik Municipal District Heating Service.

U.N. Symposium on the Development and Utilization of Geothermal

Resources, in Geothermics. 2(1):1602-1612.

283 Hernandez, J.W.

1977 Underground injection program set under Safe Drinking Water Act. Water and Sewage Works 24(10):67-69.

1260 Heronemus, W.E. and J.G. McGowan.

1975 Ocean thermal power and windpower systems: natural solar energy conversion for near-term impact on world energy markets.

Energy Symposium, AAA Science and Technology Series. 35:491-506. AAS74-031.

1383 y Herrick, C.S. and K.P. Zarnoch.

1980 Heat storage capability of a rolling cylinder using Glauber's salt.

Thermal Energy Storage: Fourth Annual Review Meeting, Tysons

Corner, VA, Dec. 3-4, 1979. 239-260. CONF-791232.

1544 e Hersh, H.N.

1980 Experimental evaluation of thermal energy storage: status report. Proceedings of the DOE Thermal and Chemical Storage Annual Contractors' Meeting. 17-19. 
183 Hewitt, C.H.

1963 Analytical techniques for recognizing water-sensitive reservoir rocks. Journal of Petroleum Technology 15:813-818.

1597 Hibsch, G. and A. Kreft.

1979 Determination of aquifer transport parameters. Journal of the Hydraulics Division 105(HY9):1137-1151.

1823 Hilberath, F. and J. Teggers.

1979 Method of conveying heat energy. U.S. Patent \# 4,109,701.

969 Hildebrandt, A.F.

1974 Potential of Solar Energy for Texas. State of Texas, Governor's Energy Advisory Council. Project NT-3.

$184 \mathrm{Hill}$, C.T.

1972 Thermal pollution and its control. Environmental Affairs 2(2):406-420.

1476 Hill, J., J. Harrar, C. Otto, S. Deutscher, H. Crampton, R. Grogan and $V$. Hendricks.

1979 Apparatus and Techniques for the Study of Precipitation of Solids and Silica from Hypersaline Geothermal Brine. Lawrence Livermore Laboratory, Livermore, CA. 9pp. UCRL -52799.

826 Hill, R.F. (ed).

1976 Energy technology 3: commercialization. Proceedings of the 3rd Energy Technology Conference, Government Institutes, Inc, Washington. $335 \mathrm{pp}$.

1018 Hockett, R.S. and R.W. Serth.

1977 High temperature thermal energy storage system: $\mathrm{Na}_{2} \mathrm{SO}_{4}+$ $\mathrm{SO}_{3} \rightleftarrows \mathrm{Na}_{2} \mathrm{~S}_{2} \mathrm{O}_{7}$. 12th Intersociety Energy Conversion Engineering Conference. $2: 540-546$.

702 Hockman, E.L.

1972 Requirements for adequate protection of our nation's drinking water. Ground Water 10(4):2-5.

1435 Hodgkinson, D.P.

1979 A Mathematical Model for Hydrothermal Convection Around a Radioactive Waste Depository in Hard Rock. AERE Harwe11, Theoretical Physics Division, Oxfordshire, England. 47 pp.

185 Hoeppner, S.

1974 Combating air and gas problems. Water Well Journal 28(5):29-30. 
186 Hoffman, H.W.

1978 Overview of aquifer thermal energy storage program.

Thermal Energy Storage in Aquifers Workshop, Lawrence Berkeley Laboratory, May 10-12.

282

1978 Aquifers for Seasonal Thermal Energy Storage: An Overview of the DOE-STOR Program.

Oak Ridge National Laboratory, Oak Ridge, TN. 2 pp. CONF$7805131-1$.

1019 Hoffman, H.W., R.J. Kedl, and C.J. Swet.

1977 ERDA program on thermal energy storage at temperatures below 250 C.

ANS Transactions 16:413-414.

1131 Hoffman, H.W., R.J. Kedl, and R.A. Duscha.

1978 Thermal Energy Storage for Industrial Waste Heat Recovery. U.S. Department of Energy, Division of Energy Storage Systems, Washington. $7 \mathrm{pp}$. DOE/NASA/1034-78/2.

187 Hoffman, H.W., S.K. Fraley and R.J. Kedl (compilers).

1977 Proceedings of the Second Annual Thermal Energy Storage Contractors' Information Exchange Meeting: Sept. 29-30, Gatl inburg, TN. Oak Ridge National Laboratory, Oak Ridge, TN. 396 pp. CONF-770955.

1574 Hoffmann, M.

1976 Problematyka Sztucznego Zasilania Wod Podziemnych Przez Otwory Studzienne. [Problems of Ground Water Artificial Recharge Through wells.]

Tech Poszukiwan Geol 15(1):42-45. [in Polish].

1299 Hogenson, G.M., and B.L. Foxworthy.

1965 Ground Water in the East Portland Area, Oregon.

U.S. Geological Survey, Arlington. 78 pp. Water-Supply Paper 1793.

909 Holm, L.W.

1976 Status of $\mathrm{CO}_{2}$ and hydrocarbon miscible $0 i 1$ recovery methods. Journal of Petroleum Technology 28:76-84.

1667 Holman, A.S. and L.A. Abbatiello.

1980 Annual Cycle Energy System (ACES) Performance Report: November 1977 - September 1978.

Oak Ridge National Laboratory, Oak Ridge, TN. 74 pp. ORNL/CON-42.

827 Holman, J.P.

1976 Heat Transfer.

McGraw Hi11, Inc. New York. 4th ed. 528 pp. 
622 Holt, L., R. Jones and G. Hagey.

1978 Environmental Development P1an (EDP): Energy Storage Systems, FY 1977.

U.S. Dept. of Energy, Asst. Secretary for Energy Technology and Asst. Secretary for Environment, Washington. DOE/EDP-0015.

188 Holton, W.C.

1951 Effect of molecular weight of entrained fluid on the performance of steam-jet ejectors.

Transactions of the ASME Oct:905-910.

1270 Holzer, T.L.

1976 Ground failure in areas of subsidence due to ground water decline in the United States.

International Association of Hydrological Sciences, Proceedings of the Anaheim Symposium. 423-433.

189 Holzschuh, J.C.

1976 A Simple computer program for the determination of aquifer characteristics from pump test data.

Ground Water 14(5):283-285.

1668 Honeywe 11 Inc., Energy Resources Center.

1980 Economic Evaluation of the Annual Cycle Energy System (ACES):

Vol. 1, Executive Summary.

Energy Resources Center, Honeywe 11 Inc., Minneapolis, MN. ORNL/Sub-7470/1-V1.

1293 Honeywe11 Incorporated.

1979 Heat Pump Centered Integrated Community Energy Systems: System Development, Honeywe 11 Energy Resources Center Interim Report. Argonne National Laboratory, Argonne, IL. ANL/ICES-TM-31.

1807 Hoogendoorn, C.J., C. DenOuden.

1978 Solar heating studies in the Netherlands.

Proceedings of the 1978 Annual Meeting of the American Section of the International Solar Energy Society, Inc. 567-574.

829 Hooper, F.C.

1976 Design of a solar heating system using seasonal heat storage. 1976 Solar Energy Conference 8:260-261 (Abstract).

$1315 a$

1979 Annual cycle storage for building heating. Proceedings of Solar Energy Storage Options, San Antonio, TX. March 19-20. 1:11-22. CONF-790328-P1.

955 Hooper, F.C., C.R. Attwater, A.P. Brunger, R.J.D. Cook, and J.D. McClenahan.

1978 Solar Space Heating Systems Using Annual Heat Storage: Progress Report for July-December 1977. University of Toronto, Department of Mechanical Engineering. 127 
pp. DOE CO0/2939-5.

1362 Hooper, F.C., J.D. McClenahan, J.D. Cook, F. Baylin, R. Monte, S. Siliman.

1980 Analysis of Community Solar Systems for Combined Space and Domestic Hot Water Heating Using Annual Cycle Thermal Energy Storage. Solar Energy Research Institute, Golden, C0. 7 pp. SER I / TP $-355-570$.

699 Hooper, F.C. and C.R. Attwater.

1977 A Design Method for Heat Loss Calculation for In-Ground Heat Storage Tanks. ASME Winter Annual Meeting, Heat Transfer in Energy Conservation. 39-43.

954

1977 Solar Space Heating Systems Using Annual Heat Storage: Progress Report, January-June 1977. University of Toronto, Department of Mechanical Engineering. 66 pp. DOE. COO/2939-4.

828 Hooper, F.C. and F.R. Lepper.

1950 Transient heat flow apparatus for the determination of thermal conductivities.

Transactions, American Society of Heating and Ventilating Engineers. $56: 309-324$.

1277 Hooper and Angus Associates Ltd.

1979 Energy Mines and Resources Canada: Study to Examine the Tech. and Econ. Feasibility of Using Aquif. as a Chilled Water Source or Storage Med. for Building AC Systems. Hooper and Angus Associates Ltd., Hydrology Consultants, Toronto. Vol. 1. $42 \mathrm{pp}$.

1979 Energy Mines and Resources Canada: Study to Examine the Tech. and Econ. Feasibility of Using Aquif. as a Chilled Water Source or Storage Med. for Building AC Systems.

Hooper and Angus Associates Ltd., Hydrology Consultants, Toronto. Vol. 2. $60 \mathrm{pp}$.

1728

1980 Study to Examine the Ability of Central Receiver Type of Solar Collection to Utilize the Canadian Solar Energy Resource Compared to Flat Plate Collection Techniques. Hooper and Angus Associates Ltd, Toronto. 43 pp.

700 Horner, D.R.

1951 Pressure build-up in wells. Proceedings, Third World Petroleum Congress: Drilling and Production. The Hague. 2:503-522. 
190 Horton, C.W. and F.T. Rogers.

1945 Convection currents in a porous medium.

Journal of Applied Physics 16:367-370.

191 Horvath, E. and G.H. Elkan.

1978 A Model aquifer system for biological compatibility studies of proposed deep well disposal systems. pp. 174-185 in Proposed Deep Well Disposal Systems, National Well Water Assoc., Ground Water Technology Division.

1451 Hourmanesh, M., R. Hourmanesh and D.B. Elmer.

1978 Earth-air heat exchanger.

Proceedings, Annual Meeting of the American Section of the

International Solar Energy Society: August 28-31. pp. 16-21.

193 Howard, J.

1978 Geothermal Resource and Reservoir Investigations of U.S. Bureau of Reclamation Leaseholds at East Mesa, Imperial Valley, Cal ifornia.

Lawrence Berkeley Laboratory, Earth Sciences Division, Berkeley, CA. 305 pp. LBL-7094.

1177 ah Howard, J.H., A.N. Graf and P.C. van de Kamp.

1978 Subsurface geology of the East Mesa geothermal anomaly. Pages 124-127 in Earth Science Division Annual Report, Lawrence Berkeley Laboratory, Berkeley, CA. LBL-8648.

1177 aj Howard, J.H. and W.J. Schwarz.

1978 Geothermal reservoir engineering management program.

Pages 130-134 in Earth Science Division Annual Report, Lawrence Berkeley Laboratory, Berkeley, CA. LBL-8648.

1414 Howard, N.W., B.J. Qualheim, G. Hage, M.G. Higuera, G. Pawloski and C. Bell.

1980 The LLL Continental Drilling for Scientific Purposes Data Base: DOE-funded Drill Holes.

Lawrence Livermore Laboratory, Livermore, CA. 442 pp. UCRL -52909.

1086 Hubbard, M.W.

1978 Energy Usage in the Steelfounding Industry. Conference Paper.

195. Huber, H.D., C.L. McDonald, C.H. Bloomster, and S.C. Schulte.

1978 User Manual for GEOCITY: A Computer Model for Geothermal District Heating Cost Analysis.

Pacific Northwest Laboratory, Battelle, Richland, WA. 117 pp. PNL-2742.

967 Hundemann, A.S.

1969 Petroleum Exploration, Production, and Recovery Methods:

Citations from the NTIS Data Base.

National Technical Information Service, Springfield, VA. 219 pp. 
NTIS/PS-70/0529.

1403 Hunnicutt, N.B.

1969 A Professional driller's evaluation of geothermal drilling and production problems.

pp. 21-25 in Drilling Production and Practice, American

Petroleum Institute.

1228 Huntsinger, J., R. Quade, D. Peterman, J. DeGraff, and C.

McDonald.

1976 Process Heat in Petroleum Refinery Applications: Final Report. General Atomic Co., San Diego, CA. ORNL/Sub-4188-1. (Microfiche).

910 Hutchison, S.0.

1977 How downhole tools improve steam stimulation efficiency. World 0 il $185: 56-60$.

830 Huxtable, D.D. and D.R. Poole.

1976 Thermal energy storage by the sulfuric acid-water system. International Solar Energy Society, American Section. 8:178-191.

1557 Huyakorn, P.S., G.F. Pinder, C.R. Faust and J.W. Mercer.

1978 Finite Element Simulation of Two-Phase Flows in Porous Media. ASME Proceedings of the Symposium on Computational Techniques for Boundary Value Problems in Applies Mechanics, Dec 10-15.

196 Huyakorn, P.S. and C.R. Dudgeon.

1976 Investigation of two-regime well flow. Journal of the Hydraulics Division ASCE 102(HY9):1149-1165.

962 Hydroscience, Inc.

1979 Assessment of Long-Distance Thermal-Energy Transport: A Comparison Between Water, Steam, and Hot 0ils. Hydroscience, Inc., Knoxville. ORNL/SUB-79/14274/1 DOE.

1614 INTERA Environmental Consultants, Inc.

1979 Revision of the Documentation for a Model for Calculating Effects of Liquid Waste Disposal in Deep Saline Aquifers. INTERA Environmental Consultants, Inc., Houston, TX. 73 pp. PB80-12254 2.

1882 Indian Institute of Technology.

1979 National Solar Energy Convention 1979 of Solar Energy Society of India.

Indian Institute of Technology, Bombay. 543 pp. CONF-791229. (Microfiche).

1110 Industrial Heating.

1975 Utilization of waste heat from quenching operations. Industrial Heating May:36-39.

198 Ineson, J.

1963 Applications and limitations of pumping tests: hydrogeological significance. 
Journal of the Institute of Water Engineers 17:200-215.

285 Ineson, J. and D.A. Gray.

1964 Electrical investigations of borehole fluids. Journal of Hydrology 1:204-218.

1463 Ingri, N., W. Kakolowicz, L.G. Sillen and B. Warnvist.

1967 High-speed computers as a supplement to graphical methods--V: HALTAFALL, a general program for calculating the composition of equilibrium mixtures. Talanta, 14:1261-1286.

199 Intercomp Resource Development and Engineering, Inc.

1976 A Model for Calculating Effects of Liquid Waste Disposal in Deep Saline Aquifer: Part I - Development; Part II - Documentation. U.S. Geological Survey, Water Resources Division, Reston, VA. 263 pp. PB-256 903.

1269 International Association of Scientific Hydrology and Unesco.

1970 USA Proceedings of the Tokyo Symposium on Land Subsidence. International Association of Scientific Hydrology and Unesco. Vol. 2, pp. 325-660.

1453 International District Heating Association.

1979 Official Proceedings, 70th Annual Conference of the International District Heating Association. At The Balsams, Dixville Notch, $\mathrm{NH}$, June 18-20, 1979.

International District Heating Association, Pittsburgh. Vol. LXX.

1454

1980 Official Proceedings, 71st Annual Conference of the International District Heating Association. At Boyne Highlands Inn, Harbor Springs, MI, June 23-25, 1980.

International District Heating Association, Pittsburgh. Vol. LXXI.

1136 International Gas Union, Int'l Institute of Refrigeration and

Institute of Gas Technology.

1970 Second International Conference on Liquefied Natural Gas, Maison de la Chimie, Paris, October 19-23.

International Gas Union, Int'l Institute of Refrigeration and Institute of Gas Technology. Part 1.

1137

1970 Second International Conference on Liquefied Natural Gas, Maison de la Chimie, Paris, October 19-23.

International Gas Union, Int'l Institute of Refrigeration and Institute of Gas Technology. Part 2.

9999ee International Solar Energy Society, UK Section.

1978 Storage in Solar Energy Systems: Conference 1978, London, May 5. International Solar Energy Society, UK Section, London. 75 pp. 
1154 International Solar Energy Society - UK Section.

1978 Solar Energy for Industry, Conference $(C-14)$ at the Royal

Institution, February.

International Solar Energy Society, U.K. Section. 96 pp. WIX 3HA ISSN No. 0306-7874.

1114 Intertechnology Corporation.

1977 Analysis of the Economic Potential of Solar Thermal Energy to

Provide Industrial Process Heat: Final Report.

Intertechnology Corporation, Warrenton, VA. 68 pp. Vol. 1. ERDA c00/2829-1.

617 Iris, P.

1978 Heliogeothermie a Faible Profondeur avec Pompe a Chaleur Associee.

Experimentation de Stockage de Chaleur Intersaisonnier en Nappe Phreatique Campuget (Gard) 1977-1978.

1465 Izatt, R.M., D. Eatough, J.J. Christensen and C.H. Bartholomew.

1969 Calorimetrically determined $\log \mathrm{K}, \Delta \mathrm{H}$ and $\Delta \mathrm{S}$ values for the interaction of sulphate ion with several bi- and ter-valent metal ions.

Journal of Chemical Society 1:47-53.

595 J. Donald Kroeker and Associates.

1964 Report on Loads, Capacities, and Operating Conditions of the Heat Pump Air-Conditioning System in the Equitable Building, Portland, OR.

J. Donald Kroeker and Associates. 9 pp.

1246 JRB Associates, Inc.

1977 Identifying Small Building Types and Requirements for Microprocessor Energy Management Systems: Final Report. JRB Associate, Inc. DOE/TIC-10633.

201 Jacob, C.E.

1940 On the flow of water in an elastic artesian aquifer. Transactions, American Geophysical Union 21:574-586.

1941 Notes on the elasticity of the Lloyd Sand on Long Island, NY. Transactions, American Geophysical Union 22:783-787.

1943 Correlation of ground-water levels and precipitation on Long Is land, NY: Part 1. theory.

Transactions, American Geophysical Union 24:564-573.

1944 Correlation of ground-water levels and precipitation on Long Island, NY: Part 2. correlation of data.

Transactions, American Geophysical Union 25:928-939. 
205 Jacob, C.E.

1946 Radial flow in a leaky artesian aquifer.

Transactions, American Geophysical Union 27(2):198-205.

1946 Report of the subcommittee on permeability: Appendix A. Transactions, American Geophysical Union 27(2):245-273.

1947 Drawdown test to determine effective radius of artesian well. Transactions, American Society of Civil Engineers 112:1047-1064.

208

1949 Flow of ground water.

Engineering Hydraulics: Hydraulics Conference. 321-385.

209 Jacob, C.E. and S.W. Lohman.

1952 Nonsteady flow to a well of constant drawdown in an extensive aquifer.

Transactions, American Geophysical Union 33(4):559-569.

1234 Jacobs Engineering Co.

1976 Application of Solar Energy to the Supply of Industrial Hot Water: Energy Reduction Analys is of Conceptual Design Report. Jacobs Engineering Co., Pasedena, CA. TIDF-27803 (Microfiche).

1977 Application of Solar Energy to the Supply of Industrial Hot Water: Final Design Report.

Jacobs Engineering Co., Pasadena, CA. Vo1. 1. TID-27808 (Microfiche).

1138 Jaeger, F.A., D.G. Beshore, F.M. Miller, and E.M. Gartner.

1978 Application of Thermal Energy Storage in the Cement Industry: Final Report-September 1977-March 1978.

Martin Marietta Aerospace, Denver, CO and Portland Cement Association, Skokie, IL. 198 pp. CONS-5085-1.

1872 Jaeger, F.A., M.T. Howerton, S.E. Podlaseck, J.E. Meyers, D.G.

Beshore and W.R. Haas.

1978 Development of Ammoniated Salts: Thermochemical Energy Storage Systems, Phase 1B, Final Report, February-September 1977.

Martin Marietta Corporation, Denver, C0. 153 pp. SAN-1229-1. (Microfiche).

1247 Jaehne, H., M.A. Karnitz, A. Rubin, and P.H. Margen.

1979 District heating cogeneration application studies for the Minneapolis St. Paul area.

Forty First Annual Meeting of the American Power Conference, Chicago, April 23-25. CONF-790-443-3. 
210 James, $\mathrm{R}$.

1970 Collection and transmission of geothermal fluids.

U.N. Symposium on the Development and Utilization of Geothermal Resources, in Geothermics. 1:99-105.

831 Jameson, M.S., Jr.

1978 Panel Discussion.

Independent Petroleum Association of America. Washington. 14 pp.

1020 Janes, C.W.

1979 Increasing Gas Turbine Efficiency Through the Use of a Waste Heat Methanol Reactor.

American Chemical Society, Washington, DC. 1968-1972.

211 Jank, R.

1978 Aquifer storage efforts in Germany. Proceedings of the Thermal Energy Storage in Aquifer Workshop. Lawrence Berkeley Laboratory. 3 pp. CONF-7805140.

212 Japhet, R.E.

1967 Heat pumps: manufacturer's viewpoint. Journal ASHRAE 9(9):41-42.

832 Jardine, D.M. and D.W. Jones.

1978 Phoenix House: Solar-Assisted Heat Pump System Evaluation. Kaman Science Corp., Colorado Springs, CO. ER-712. (Draft).

1021 Jaske, R.T., M.H. Karr, and C.J. Touhi11.

1970 Multiple purpose use of thermal condenser discharges from large nuclear systems to supplement inter-regional water supply. Chemical Engineering Progress Symposium Series. 67(107):26-30.

1623 Javandel, I. and P.A. Witherspoon.

1979 A Study of Partial Penetration in a Two Layered Aquifer: Analytical Solution. Lawrence Berkeley Laboratory, Berkeley, CA. 25 pp. LBL-9479.

1732 Jayadev, T.S. and M. Edesess.

1980 Solar Ponds and Their Applications.

Solar Energy Research Institute, Golden, CO. 12 pp. SERI/TP-733-617.

213 Jenkins, $N$.

1976 ITEC: A congress that stuck to its theme. Energy International 13(12):15-25.

1974 Fuel crisis enhances feasibility of long distance heat transport. Energy International May:27-28. 
214 Jet Propulsion Laboratory Staff.

1974 Conference on Research for the Development of Geothermal Energy Resources.

California Institute of Technology, Jet Propulsion Laboratory, Pasadena, CA. 349 pp. N75-20831-864.

1723 John Hix, Scanada, and Acres Shawinigan Ltd.

1978 Design of South March Energy Conserving Community: Part B. John Hix, Architects and Planners; Scanada, Engineering Consultants Ltd.; and Acres Shawinigan Ltd.

961 John Wiley and Sons.

1975 Storage of massive amounts of energy. pp. 207-223 in The Solar-Hydrogen Alternative. John Wiley and Sons.

1542 Johns Hopkins University, Applied Physics Laboratory.

1980 Energy Programs at the Johns Hopkins University Applied Physics Laboratory: Quarterly Report, April -June 1980. Johns Hopkins University, Applied Physics Laboratory, Laure1, MD. $54 \mathrm{pp}$.

1368 Johnson, A.B.,Jr., W.J. Bailey, R.E. Schreiber, and F.M. Kustas. 1980 Annual Report-FY 1979: Spent Fuel and Fuel Pool Component Integrity.

Pacific Northwest Laboratory, Battelle, Richland, WA. 77 pp. PNL-3171.

1330 Johnson, A.B., Jr., and B. Francis.

1980 Durability of Metals from Archaeological Objects, Metal Meteorites, and Native Metals.

Pacific Northwest Laboratory, Battelle, Richland, WA. PNL-3198.

1188 Johnson, A.I.

1967 Specific Yield: Compilation of Specific Yields for Various Materials.

U.S. Geological Survey, Arlington. 74 pp. Water-Supply Paper $1662-D$.

1189 Johnson, A.I., R.C. Prill, and D.A. Morris.

1963 Specific Yield: Column Drainage and Centrifuge Moisture Content. U.S. Geological Survey, Arlington. $60 \mathrm{pp}$. Water-Supply Paper $1662-A$.

1696 Johnson, A.I., R.P. Moston and S.F. Versaw.

1966 Laboratory Study of Aquifer Properties and Well Design for an Artificial-Recharge Site. U.S. Geological Survey. Water-Supply Paper 1615-H.

911 Johnson, C.E.

1976 Status of caustic and emulsion methods. Journal of Petroleum Technology 28:85-92. 
215 Johnson, H.E. and A.C. Nestle.

1968 A Survey of Corrosion Control in Drilling and Annular Fluids. National Association of Corrosion Engineers, Houston, TX. 15 pp. Publication 10168 .

1806 Johnson, R.C., C.E. Kurt, G.F. Dunham.

1980 Experimental determination of thermoplastic casing collapse pressures.

Ground Water 18(4):346-350.

704 Johnson, T.L.

1977 Pumping tests provide useful data. Johnson Drillers Journal 49(2):4-7.

216 Johnson, W.C.

Aquaculture Using Geothermal Energy.

Oregon Institute of Technology. $8 \mathrm{pp}$.

1378 Johnson Division, UOP Inc.

1975 Developing and completing water wells.

pp. 295-312 in Ground Water and Wells, Johnson Division, UOP Inc.

1975 Well drilling methods.

pp. 209-248 in Ground Water and Wells, Johnson Division, UOP Inc.

1975 Water well design.

pp. 185-208 in Ground Water and Wells, Johnson Division, UOP Inc.

1975 Installing well screens.

pp. 249-276 in Ground Water and Wells, Johnson Division, UOP Inc.

1382

1975 Well screens.

pp. 143-156 in Ground Water and Wells, Johnson Division, UOP Inc.

1541

1975 Ground Water and Wells.

Johnson Division, UOP Inc., Saint Paul, MI. 440 pp.

217 Jones, L.L. and J.P. Warren.

1976 Land subsidence costs in the Houston-Baytown Area of Texas. American Waterworks Association Journal 68(11):597-599.

1325 Jones, R., R. Krajewski and E. Dennehy.

1979 Case study of the Brownell Low Energy Requirement House: thermal storage analysis. Solar Energy Storage Options Workshop, San Antonio, TX. 15 pp. CONF-790328-6. BNL-25832. 
912 Jones, S.C. and W.0. Roszelle.

1978 Graphical techniques for determining relative permeability from displacement experiments. Journal of Petroleum Technology 30:807-817.

1488 Jorda, R.M.

1980 A Performance Evaluation of Magma Power Company's Reinjection Well \#46-7 at the East Mesa KGRA, Cal ifornia.

Sandia Laboratories, Albuquerque, NM. 32 pp. SAND79-7127.

1497

1978 A Mathematical Model of Damage Collars in Water Reinjection Wells.

Completion Technology Company, Houston, TX. 8 pp. SAND78-7063.

1501

1978 An Analysis of Water Reinjection at the Niland Geothermal Test Site.

Completion Technology Co., Houston, TX. 84 pp. SAND78-7052.

1502

1978 An Engineering Study of Water Reinjection for Geothermal Systems. Completion Technology Co., Houston, TX. 102 pp. SAND78-7009.

1538

1980 Predicting Injector Performance at the Proposed Magma-SDG\&E Fifty Megawatt Geothermal Power Plant. Sandia Laboratories, Livermore, CA. 23 pp. SAND79-7128, UC-66c.

$1579 \mathrm{cq}$

1978 The Effects of corrosion and scale deposits on the capacity of water reinjection wells in liquid dominated geothermal systems. Geothermal Resources Council Transactions 2:341-344.

705 Jorgensen, D.G.

1968 An Aquifer test used to investigate a quality of water anomaly. Ground Water 6(6):18-20.

1774

1980 Relationships between Basic Soil-Engineering Equations and Basic Groundwater Flow Equations.

U.S. Geological Survey. Water-Supply Paper 2064.

1177v Juprasert, S.

1978 Two-phase flashing flow in geothermal wells.

Pages 70-71 in Earth Science Division Annual Report, Lawrence

Berkeley Laboratory, Berkeley, CA. LBL-8648.

1190 Kahan, C.V.

1979 An Analysis of the Institutional Barriers to the Widespread Use of Thermal Energy Storage Systems in Residential Construction. George Washington University, Office of Energy Programs, School 
of Engineering and Applied Science, Washington. $185 \mathrm{pp}$.

1239 Kalhammer, F.R.

1979 Energy-storage systems.

Scientific American 241(6):56-65.

706 Kalhammer, F.R. and P.Z. Zygielbaum.

1974 Potential for Large-Scale Energy Storage in Electric Utility Systems.

American Society of Mechnical Engineers, New York. 12 pp. 74-WA/Ener-9.

9999a Kalhammer, F.R. and V.R. Cooper.

1975 Energy storage. Pp. 11-19 in EPRI Research Progress Report FF2, Electric Power Research Institute.

218 Kalousek, G.L. and S.Y. Chaw.

1976 Research on cements for geothermal and deep oil wel1s. Society of Petroleum Engineers Journal 16(6):307-309.

1784

1976 Research on cements for geothermal and deep oil wells. Sociey of Petroleum Engineers Journal Dec:207-309.

1233 Kaplan, S.I.

1977 Energy Use and Distribution in the Pulp, Paper and Boardmaking Industries.

Oak Ridge National Laboratory, Oak Ridge, TN. ORNL/TM-5884. (Microfiche).

1908 Kapner, M. and H. Cole.

1981 A Hydrogen energy cycle for electric utility applications. Technical and Economic Analysis Meeting, Chicago, April 22.

9999dq Karadi, G.M.

1980 Synthesis of Research and Development in Mechanical Energy Storage Technologies.

Wiscons in University, Milwaukee. 12 pp. DOE/ER-16106/T1.

833 Karanjac, J.

1972 Well losses due to reduced formation permeability. Ground Water 10(4):42-45.

219 Kassoy, D.R.

1975 Heat and mass transfer in models of undeveloped geothermal fields. Proceedings of the Second U.N. Symposium on the Development and Use of Geothermal Resources. 3:1707-1711.

220 Kassoy, D.R. and A. Zebib.

1975 Variable viscosity effects on the onset of convection in porous media. 
The Physics of Fluids 18(12):1649-1651.

707 Katayama, K. and H. Nakagawa.

1970 Research on simultaneous flow of heat and fluid through porous media.

Bulletin of the JSME $13(62): 1013-1021$.

1544 ai Katter, L.B.

1980 Application of thermal energy storage to process heat recovery in the aluminum industry.

Proceedings of the DOE Thermal and Chemical Storage Annual

Contractors' Review Meeting. 143-146.

1610

1978 Applications of Thermal Energy Storage to Process Heat and Waste Heat Recovery in the Iron and Steel Industry.

Rocket Research Company, Redmond, WA. 128 pp. N79-11373.

878 Katter, L.B. and R.L. Hoskins.

1978 Application of Thermal Energy Storage to Process Heat and Waste Heat Recovery in the Primary Aluminum Industry.

Rocket Research Co., Redmond, WA. 114 pp. CONS/5080-1.

708 Katz, D.L., M.R. Tek, and S.C. Jones.

1962 A Generalized Model for Predicting the Performance of Gas Reservoirs Subject to Water Drive.

Society of Petroleum Engineers of AIME, Dallas. 13 pp. SPE-428.

221 Katz, D.L. and M.R. Tek.

1970 Storage of natural gas in saline aquifers. Water Resources Research 6(5):1515-1521.

1191 Katz, M.L.

1961 Fluid Flow and Heat Transfer in Stratified Systems.

Ph.D Thesis, University of Maryland. 347 pp. University Microfilms, Ann Arbor, MI.

1843 Kauffman, K.W. and H.G. Lorsch.

1976 Design and Costs of High Temperature Thermal Storage Devices Using Salts or Alloys.

The American Society of Mechanical Engineers, New York. 11 pp. 76-WA/HT -34.

1141 Kauffman, K.W. and Y.C. Pan.

1973 Congruently Melting Materials for Thermal Energy Storage in Air Conditioning.

University of Pennsylvania, Philadelphia. 19 pp. PB 238543.

222 Kaveler, H.H. and Z.Z. Hunter.

1952 Observations from profile logs of water injection wells.

Petroleum Transactions, AIME 195:129-134. 
913 Kavernen Bau-Und Betrieds-GMBH.

1979 KBB Underground Storage.

Kavernen Bau-Und Betrieds-GMBH.

223 Kazmann, R.G.

1958 Problems encountered in the utilization of ground-water reservoirs.

Transactions, American Geophysical Union 39(1):94-99.

224

1971 Exotic uses of aquifers.

Journal of the Irrigation Division, ASCE 97(IR3):515-522.

225

1974 Waste surveillance in subsurface disposal projects.

Ground Water 12:412-426.

226

1975 Groundwater and environmental geology.

Environmental Geology $1: 137-142$.

227

1978 Underground hot water storage could cut national fuel needs $10 \%$. Civil Engineering 48(5):57-60.

228 Kazmann, R.G., 0.K. Kimbler and W.R. Whitehead.

1974 Management of waste fluids in salaquifers. Journal of the Irrigation and Drainage Division-ASCE 100 ( IR4) : 413-424.

229 Keady, D.M., T.W. Lins and E.E. Russel1.

1975 Status of Land Subsidence Due to Ground-Water Withdrawal Along the Mississippi Gulf Coast.

Mississippi State University, Water Resources Research

Institute. $25 \mathrm{pp}$. PB-243 558 .

612 Keenan, J.H. and F.G. Keyes.

1936 Thermodynamic Properties of Steam: Including Data for the Liquid and Solid Phases.

John Wiley and Sons, New York. 89 pp.

914 Keese, J.A. and A.L. Oden.

1975 On-site inspection helps evaluate variations in jet-perforating work.

$0 i 1$ and Gas Journal 73(50):71-74.

915

1976 Study shows big difference in commercial perforators. World 0i1 182:27-31. 
230 Keller, C.E., A.H. Davis, and J.N. Stewart, Jr.

1974 The Calculation of Steam Flow and Hydraulic Fracturing in a Porous Medium with the KRAK Code. Los Alamos Scientific Laboratory, Los Alamos, NM. 23 pp. LA-5602-MS.

1482 aa Keller, J.G. and R.C. Schmitt.

1980 Heat pumps in low temperature applications.

Energy to the 21st Century: 15th Intersociety Energy Conversion Engineering Conference, Seattle, WA, August 18-22. 1:167-169.

1735 Kelly, W.E.

1980 Ground and surface water interaction: legal aspects. Journal of Water Resource Planning and Management Division-ASCE $106(1): 55-61$.

231 Kemper, W.D., W.R. Walker and J. Sabey.

1979 Trans-Seasonal Storage of Energy in Moist Soils. Colarado State University, Department of Agricultural and Chemical Engineering, Fort Collins, CO. $10 \mathrm{pp}$.

1546 Kemper, W.D. and W.R. Walker.

1978 Trans-Seasonal Storage of Solar Energy: Final Report of Innovative Research Program Subtask, December 1977-September 1978.

Colorado State University, Solar Energy Applications Laboratory, Fort Collins. 21 pp. C00-4546-3.

1022 Kennedy, A.S., C. Lee, A.A. Davis, and H.A. Davis.

1979 Office Complex Analyzed for Application of Integrated Community Energy Systems.

American Chemical Society, Washington, DC. 2074-2078.

1748 Kestin, J., R. DiPippo. H.E. Khalifa and D.J. Ryley (eds.).

1980 Sourcebook on the Production of Electricity from Geothermal Energy.

U.S. Department of Energy. 997 pp. DOE/RA/28320-2.

232 Keys, W.S.

1967 The Application of radiation logs to groundwater hydrology. Proceedings of the Symposium on Isotopes in Hydrology, Vienna, Nov. 14-18. 477-488.

834

1967 Borehole Geophysics as Applied to Groundwater. pp. 598-614 in L.W. Morley (ed.), Mining and Groundwater Geophysics/1967, Canada, Department of Energy, Mines and Resources, Ottawa. Report No. 26.

233 Keys, W.S. and R.F. Brown.

1978 The Use of Temperature Logs to Trace the Movement of Injected water. 
U.S. Geological Survey, Water Resources Division.

$15 \mathrm{pp}$.

234 Khaleel, R. and D.L. Redde11.

1977 Simulation of Pollutant Movement in Groundwater Aquifers. Texas A\&M University, Texas Water Resources Institute, College Station, TX. 248 pp. PB-268835.

235 Kihara, D.H. and P.S. Fukunaga.

1975 Working fluid selection and preliminary heat exchanger design for a Rankine cycle geothermal power plant.

Proceedings of the Second U.N. Symposium on the Development and Use of Geothermal Resources. 2013-2019.

709 Kilgore, L.A. and D.C. Washburn, Jr.

1970 Energy storage at site permits use of large excavators on smal1 power systems.

Westinghouse Engineer Nov:1-4.

710 Kilpatrick, F.A.

1976 Water Measurement and Monitoring in Energy Developing Areas. U.S. Geological Survey, Arlington. 7 pp. EPA 600/7-76-002.

236 Kimbler, 0.k.

1970 Fluid model studies of the storage of fresh water in saline aquifers. Water Resources Research 6(5):1522-1527.

237 Kimbler, 0.K., R.G. Kazmann and W.R. Whitehead.

1975 Cyclic Storage of Fresh Water in Saline Aquifers. Louisana State University, Louisiana Water Resources Research Institute, Baton Rouge, LA. 77 pp. Bu11. 10.

1192 Kimmel, G.E.

1963 Contamination of ground water by sea-water intrusion along Puget Sound, WA: an area having abundant precipitation. Paper 475-B, pp. 182-185 in Geological Survey Research, Short Papers in Geology and Hydrology, Articles 1-59, U.S.G.S.

593 King, S. (ed).

1979 Supplement to Proceeding of Solar 79 Northwest. Pacific Northwest Solar Energy Association, Seattle. 86 pp.

1695 Kipp, K.L.

1973 Unsteady flow to a partially penetrating, finite radius well in an unconfined aquifer. Water Resources Research 9(2):448-462.

1089 Kirchner, R.P. and E. Stamper.

1972 Energy Conservation Through Waste Heat Utilization. Newark College of Engineering, Department of Mechanical Engineering, Newark, NJ. 155-159. 
623 Kirschbaum, H.S. and S.E. Veyo.

1977 An Investigation of Methods to Improve Heat Pump Performance and Reliability in a Northern Climate. Westinghouse Electric Corp., Pittsburgh, and Electric Power Research Institute, Palo Alto, CA. EPRI EM-319.

1453c Kirvela, K.

1979 Conversion of condensing steam turbines for remote base load heat supply for district heating systems.

Official Proceedings, 70th Annual Conference of the International District Heating Assn. June 18-20. Section 8.

238 Klarsfled, S.M.

1970 Champs de temperature associes aux mouvements de convection naturelle dans un millieu poreux limite.

Revue Generale de Thermique 108:1403-1423.

239 Kley, W. and H.G. Nieskens.

1975 Moglichkeiten der warmespeicherung in einem porengrundwasserleiter und technische probleme bei einer ruckgewinnung der energie.

z. dt. Geol. Ges. 126:397-409.

711 K1 inkenberg, L.J.

1941 The Permeability of porous media to liquids and gases. pp.203-213 in Drilling and Production Practice, American Petroleum Institute, Dallas.

1797 Klotz, D., H. Moser and P. Trimborn.

1978 Single-borehole techniques: state of the art and examples of recent applications.

International Symposium on Isotope Hydrology, Neuherberg, F.R. Germany, June 19-23. 24 pp. CONF-780674-2.

1464 Knight, J.E.

1977 A Thermochemical study of alunite, enargite, luzonite and tennantite deposits.

Economic Geology 72:1321-1336.

712 Koch, R.K., E.D. Calvert, C.R. Thomas, and R.A. Beall.

1976 Vapor Pressure of Liquid Titanium (2,008 to 2,379 K) and Liquid Platinum $(2,045$ to $2,379 \mathrm{~K})$.

U.S. Department of Interior, Bureau of Mines. 14 pp. Report Investigation 7271 .

1565 Koenig, E.F. and A.B. Cambel.

1979 Utility Rate Structures and Distributed Thermal Energy Storage: A Cost Benefit Analysis. George Washington University, Sch. of Engineering and Applied Science, Off. of Energy Programs, Washington. 38 pp. DSE-2411-T1. 
286 Komedera, M.

1956 The Domestic heat pump: standard equipment of the future.

Engineering 182(4720):236-40.

599

1957 Heat pumps for water heating.

Heating and Ventilating Engineering and Journal of Air Conditioning, 30(359):554-564.

600

1957 Heat from ground utilised by heat pump: part 2.

Heating and Ventilating Engineering and Journal of Air Conditioning, 31(363):122-128.

615

1957 Heat from ground utilised by heat pump: part 1 . Heating and Ventilating Engineering and Journal of Air Conditioning $31(362): 65-72$.

715 Konczak, Z.

1975 The Influence of the temperature on the phenomena of consolidation in deformable porous media. Bullet in De L'Academie 13(7):345-354.

1800 Kopp, J.F. and G.D. McKee.

1979 Methods for Chemical Analys is of Water and Wastes. Environmental Monitoring and Support Laboratory, U.S. Environmental Protection Agency, Cincinnati, $\mathrm{OH}$. EPA-600/4-79-020.

1090 Kosaka, M. and M. Asahina.

1975 Discussions on Heat Storage Material at Low Temperature Level. Solar Use Now a Resource for People: International Solar Energy Society Conference. 193-194.

625 Kovach, E.G. (ed).

1976 Thermal Energy Storage: the Report of a NATO Science Committee Conference.

North Atlantic Treaty Organization, Scientific Affairs Division, Brussels, Belgium. 75 pp.

1091 Krause, $C$.

1975 The Ice bin cometh.

Oak Ridge National Lab Review Fall:18-23.

1545 Kreid, D.

1978 Analysis of Advanced Compressed Air Energy Storage Concepts. American Society of Mechanical Engineers, New York. 11 pp. 78-HT -53 . 
1142 Kreider, K.G. and M.B. McNeil (eds).

1977 Waste Heat Management Guidebook: NBS Handbook 121. U.S. Department of Commerce, National Bureau of Standards, Washington. $264 \mathrm{pp}$.

1193 Kreith, F., R. Boehm, J. Mitchell and R. Bannerot (eds).

1978 Thermal Storage and Heat Transfer in Solar Energy Systems. American Society of Mechanical Engineers, New York. 79 pp.

1694 Kreitler, C.W.

1977 Fault contol of subsidence, Houston, Texas. Goundwater 15(3):203-214.

596 Kreitlow, D.B.

1978 Geothermal We11 Downhole Heat Exchanger Design Analysis. M.S. Thesis, Oregon State University. $98 \mathrm{pp}$.

287 Krishnaswamy, V.S. and R. Shankar.

1974 Geothermal fields in India explored for power generation. Geothermics 3:124-125.

1900 Kriz, T., A. Rabl, and C.J. Swet.

1981 Thermal energy storage concepts for active solar thermal process heat and building applications.

Technical and Economic Analysis Meeting, Chicago, April 22.

288 Kroeger, P.G. and S. Ostrach.

1974 The Solution of a two-dimensional freezing problem including convection effects in the liquid region. International Journal of Heat Mass Transfer 17:1191-1207.

291 Kroeker, J.D., R.C. Chewning, and C.E. Graham.

1948 Heat pump results in Equitable Building.

Heating, Piping, and Air Conditioning, 20(6):1-7.

289 Kroeker, J.D. and R.C. Chewning.

1948 A Heat pump in an office building. Heating, Piping, and Air Conditioning, 20(2):1-8.

1953 Costs of operating the heat pump in the Equitable Building. Heating, Piping and Air Conditioning, 25(11):135-144.

916 Kruger, P. and H.J. Ramsey, Jr.

1974 Stimulation and Reservoir Engineering of Geothermal Resources. Stanford University, Stanford Geothermal Program, Stanford, CA. 142 pp. PB 239718.

1977 Stimulation and Reservoir Engineering of Geothermal Resources:

Final Report Sept. 1972 - June 1977.

Stanford University, Stanford Geothermal Program, Stanford, CA. 
121 pP. SGP-TR-21. PB290683.

292 Kryukov, P.A. and E.G. Larionov.

1970 Physico-chemical sampling of high temperature wells in connection with their encrustation by calcium carbonate. Proceedings of the U.S. Symposium on the Development and Utilization of Geothermal Resources. 2(1):1624-1628.

1023 Kugeler, K., M. Kugeler, H.D. Niessen, and H. Hohn.

1975 Design of a $3000 \mathrm{MW}(\mathrm{th})$ high temperature reactor for process heat applications. Nuclear Engineering and Design 34:33-49.

294 Kukacka, L.E., A. Zeldin, J. Fontana, N. Carciello, and T. Sugama.

1977 Cementing of Geothermal Wells. Brookhaven National Laboratory, Upton, NY. 20 pp. BNL-50738.

293 Kukacka, L.E., J. Fontana, A. Zeldin, T. Sugama, W. Horn, N. Carciello, and J. Amaro.

1977 Alternative Materials of Construction for Geothermal Applications.

Brookhaven National Laboratory, Upton, NY. 24 pp. BNL-50751.

917 Kumar, A.

1977 Strength of water drive or fluid injection from transient well test data.

Journal of Petroleum Technology 29:1497-1508.

295 Kumar, A. and 0.K. Kimbler.

1970 Effect of dispersion, gravitational segregation, and formation stratification on the recovery of freshwater stored in saline aquifers.

Water Resources Research 6(6):1689-1700.

1455 Kunze, J.F. and R.C. Stoker.

1979 Floral Greenhouse Heating: Semi-Annual Technical Report. Utah Roses Inc., Sandy, UT. 48 pp. DOE-27056-2.

$1193 \mathrm{c}$ Kurosaki, Y. and R. Viskanta.

1978 Heat transfer in solar radiation absorbing fluid layer flowing over a substrate.

pp. 13-22 in Thermal Storage and Heat Transfer in Solar Energy Systems, American Society of Mechanical Engineers, New York.

1454 a Kurz, M.G.

1980 Heat pumps in steam district heating. Official Proceedings, 71st Annual Conference of the International District Heating Assn, Harbor Springs, MI, June 23-25. Sec. 7.

296 Kusuda, T. and P.R. Achenbach.

1964 Earth temperature and thermal diffusivity at selected stations in the United States. 
ASHRAE Transactions 1914:61-75.

1747 Kusuda, T. and T. Saitoh.

1980 Simplified Heating and Cooling Energy Analysis Calculations for Residential Applications. National Bureau of Standards, Washington. 136 pp. PB80-213986.

1423 Kutateladze, S.S., V.N. Moskvicheva, and Y.M. Petin.

1975 Applications of low-temperature heat carriers in geothermal energetics for use as a secondary energy source in industry. Proceedings of the Second U.N. Symposium on the Development and Use of Geothermal Resources, San Francisco, May 20-29. 2031-2035.

297 LaGarde, A.

1965 Considerations sur le transfert de chaleur en milieu poreux. Revue De L'Institut Francais Du Petrole 20(2):383-445.

1346 Laity, W.W., D.T. Aase, W.J. Apley, S.P. Bird, J.W. Currie, M.K. Drost, M. Jannol, S.C. Schulte, A. Sutey, and T.A. Williams.

1979 Assessment of Solar Options for Small Power Systems Applications: Vol. 1, Executive Summary. Pacific Northwest Laboratory, Battelle, Richland, WA. PNL-4000.

298 Lakshminarayana, V. and S.P. Rajagopalan.

1978 Type-curve analysis of time-drawdown data for partially penetrating wells in unconfined anistropic aquifers. Ground Water 16(5):328-333.

1482ee Lamb, J.P., G.F. Polansky and S.P. Bradley.

1980 Generalized performance predictions for energy conversion plants using geopressured geothermal fluids.

Energy to the 21st Century: 15th Intersociety Energy Conversion Engineering Conference, Seattle, WA, August 18-22. 1:804-809.

1281 Lamers, M.D.

1979 Measurement Requirements and Methods for Geothermal Reservoir Systems Parameters: An Appraisal. Lawrence Berkeley Laboratory, Earth Sciences Division, Berkeley, CA. 42 pp. LBL-9090.

1850 Lampinen, B.E., R.R. Gutowski, A. Topouzian, M.A. Pulick.

1979 The Indirect Brayton Energy Recovery System. American Chemical Society. 1625-1629. Paper no. 799337.

1798 Lane, R. and A. Kumar.

1980 Selection of Cooling Water Treatment at Military Installations to Prevent Scaling and Corrosion. Construction Engineering Research Laboratory. 26 pp. Technical Report $M-280$.

299 Lang, S.M.

1960 Interpretation of boundary effects from pumping test data. American Water Works Association Journal 52(3):356-364. 
300 Lang, W. and D. Stewart.

1977 Air stored for peaking power. Electrical World $187(1): 30-31$.

1799 Langmuir, D.

1971 Eh-ph determination.

pp. 597-634 in Carver, R.E., Procedures in Sedimentary Petrology, Wiley-Interscience, New York.

1589 Lappillonne, B.

1980 Long term perspectives of the U.S. energy demand: application of the MEDEE 2 model to the U.S.

Energy 5(3):231-259.

301 Lapwood, E.R.

1948 Convection of a fluid in a porous medium.

Proceedings, Cambridge Philosophical Society. 44:508-521.

956 Larson, S.P., S.S. Papadopulos, and J.W. Mercer.

1976 Transport of Water and Heat in an Aquifer Used for Hot Water Storage: Digital Simulation of Field Results. Symposium on Use of Aquifer Systems for Cyclic Storage of Water. (Abstract).

302 Lauwerier, H.A.

1955 The Transport of heat in an oil layer caused by the injection of hot fluid.

Applied Science Research 5(A):145-150.

1813 Lawn, J.

1978 Storing solar BTU: new technologies show promise but cost-effectiveness is key.

Air Conditioning and Refrigeration Business Nov:37-39.

1208 Lawrence Berkeley Laboratory, Earth Sciences Division.

1978 Proceedings of the Thermal Energy Storage in Aquifers Workshop, May 10-12, Berkeley, CA.

U.S. Department of Energy, Division of Energy Storage Systems and Lawrence Berkeley Laboratory. 126 pp. LBL-8431.

305 Lawrence Berkeley Laboratory, Earth Sciences Division.

1977 Invitational We11-Testing Symposium Proceedings, October 19-21, Berkeley, CA.

Lawrence Berkeley Laboratory, Earth Sciences Division, Berkeley, CA. 195 pp. LBL-7027.

1978 Second Invitational We11-Testing Symposium Proceedings, October 25-27, Berkeley, CA.

Lawrence Berkeley Laboratory, Earth Sciences Division, Berkeley, CA. 141 pp. LBL-8883, CONF-7810170. 
307 Lawrence Berkeley Laboratory, Earth Sciences Division.

1978 Geothermal Exploration Technology: Annual Report 1978. Lawrence Berkeley Laboratory, Earth Sciences Division, Berkeley, CA. 42 pp. LBL-8603.

1978 Mexican-American Cooperative Program at the Cerro Prieto Geothermal Field: Abstracts. 1st Sym.-Cerro Prieto Geothermal Field. Lawrence Berkeley Laboratory, Earth Sciences Division, Berkeley, CA. 32 pp. LBL-7098.

1979- Earth Sciences. Lawrence Berkeley Laboratory, Earth Sciences Division, Berkeley. $2(2), 3(1-)$.

1980- STES Newsletter: A Quarterly Review of Seasonal Thermal Energy Storage.

Lawrence Berkeley Laboratory, Earth Sciences Division, Berkeley, CA. 2(4-).

303 Lawrence Berkeley Laboratory, Energy and Environment Division.

1975 Geothermal and Geosciences Program: Annual Report 1975. Lawrence Berkeley Laboratory, Energy and Environment Division. Berkeley, CA. 195 pp. Pub-206.

304 Lawrence Berkeley Laboratory.

1977 Earth Sciences Division: Annual Report 1977.

Lawrence Berkeley Laboratory, Berkeley, CA. 169 pp. LBL-7028.

1978 Earth Sciences Division: Annual Report 1978. Lawrence Berkeley Laboratory, Berkeley, CA. 251 pp. LBL -8648.

716 Lawrence Berkeley Laboratory, Energy and Environment Division.

1977 Geothermal Subsidence Research Program Plan. Lawrence Berkeley Laboratory, Energy and Environment Division, Berkeley, CA. 111 pp. LBL-5983.

1601 Lawrence Livermore Laboratory, Earth Sciences Division.

1980 Continental Scientific Drilling Program. Lawrence Livermore Laboratory, Earth Sciences Division, Livermore, CA. $105 \mathrm{pp}$.

1491 Lawrence Livermore Laboratory, Energy and Resource Planning Group.

1979 Livermore Energy Policy Model. Lawrence Livermore Laboratory, Energy and Resource Planning Group, Livermore, CA. $14 \mathrm{pp}$. LLL TB-014. 
1474 Lawrence Livermore Laboratory.

1979 Evaluating brine injection for DOE's strategic petroleum reserve program.

Energy and Technology Review Aug:1-10. UCRL-52000-79-8.

1383aj LeFrois, R.T.

1980 Active heat exchange system development for latent heat thermal energy storage.

Thermal Energy Storage: Fourth Annual Review Meeting, Tysons

Corner, VA, Dec. 3-4, 1979. 337-352. CONF-791232.

1886 Lefrois, R.T., G.R. Knowles, A.K. Mathur and J. Budimir.

1979 Active Heat Exchange System Development for Latent Heat Thermal Energy Storage.

Honeywe 11, Inc., Minneapolis, MN. 124 pp. DOE/NASA/0038-79/1. (Microfiche).

1617 LeFrois, R.T. and A.K. Mathur.

1980 Active Heat Exchange System Development for Latent Heat Thermal Energy Storage.

Honeywe 11 Incorporated, Technology Strategy Center, Minneapolis. $224 \mathrm{pp}$. DOE/NASA/0038-80/2.

1024 Lee, D.A.

1975 Waste heat utilization for spray dryers. Ceramic Bulletin 54(9):790-791.

1177 a Lee, K.H., D. Pridmore, M. Hoversten, and H.F. Morrison.

1978 Electrical and electromagnetic computer modeling techniques. pp. 4-6 in Earth Sciences Division Annual Report, Lawrence Berkeley Laboratory, Berkeley, CA. LBL-8648.

309 Lefebre, V.

1977 Chemical Dynamics of a Confined Limestone Aquifer.

New Mexico Water Resources Research Institute, Los Cruces, NM.

253 pp. WRRI Report No. 084, PB-265666.

1889 Leffler, A.J., J. Myers, D. Weinstein.

1978 Use of Solid-State Phase Transitions for Thermal Energy Storage: Final Report, June 1, 1977-August 31, 1978.

Villanova University, Villanova, PA. 42 pp. ORNL/Sub-7299/1. (Microfiche).

310 Leggette, R.M. and M.L. Brashears.

1938 Ground-water for air conditioning on Long Island, New York. Transactions, American Geophysical Union 19:412-418.

311 Lehr, J.H.

1975 Objectives of well-drilling regulations. pp. 555-570 in Environmental Aspects of Chemical Use in Well-Drilling Operations, U.S. EPA. EPA-560/1-75-004. 
312 Lehr, J.H.

1977 Well maintenance and rehabilitation. Water Well Journal 31(8):8-9.

573

1978 Environmental aspects of low temperature thermal energy storage in aquifers.

Proceedings of the Thermal Energy Storage in Aquifers Workshop. LBL -8431.

1143 Leiby, C.C. and T.G. Ryan.

1973 Thermalphysical Properties of Thermal Energy Storage Materials: Aluminum. Air Force Cambridge Research Laboratory, Bedford, MA. 34 pp.

1898 Leigh, R.W.

1981 Solar energy storage systems analysis.

Technical and Economic Analysis Meeting, Chicago, April 22. BNL 29405.

1875 Lenz, T.

1978 Solar Generation of Industrial Steam: Final Report of Innovative Research Program Subtask, Dec. 1977-Sept. 1978. Colorado State University, Fort Collins. 10 pp. C00-4546-9.

313 Lenzer, R.C., G.W. Crosby, and C.W. Berge.

1977 Recent Developments at the Roosevelt Hot Springs KGRA. ANS Topical Meetings: Energy and Mineral Resource Recovery, Apri1 12-14. CONF-770440. 60-67.

1454s Les, J.G.

1980 Water quality control at Detroit Edison Central Heating. Official Proceedings, 71 st Annual Conference of the International District Heating Assn, Harbor Springs, MI, June 23-25. Sec 25.

314 Lesem, L.B., F. Greytok, F. Marotta, and J.J. McKetta.

1957 A Method of calculating the distribution of temperature in flowing gas wells.

Petroleum Transactions, AIME. 210:169-176.

572 Leshuk, J.P., R.J. Zaworski, D.L. Styris, and 0.K. Harling.

1976 Solar pond stability experiments. Sharing the Sun: Solar Technology in the 70's. Jt Conf of Am Sec, Int' 1 Solar Energy Soc \& Solar Energy Soc of Can. $5: 188-202$.

1978 Solar pond stability experiments.

Solar Energy 21(3):237-244.

1582v Lessard, R.D. and W.A. Blecher.

1980 CAES/FBC studies.

Mechanical, Magnetic, and Underground Energy Storage 1980 Annual 
Contractors' Review. pp. 137-146. CONF 801128.

1406 Leutwyler, $K$.

1966 Casing temperature studies in steam injection wells. Journal of Petroleum Technology 18:1157-1162.

1708 Lewis, R.W. and B. Schrefler.

1978 A fully coupled consolidation model of the subsidence of Venice. Water Resources Research 14(2):223-230.

1808 Li, K.W.

1978 A Parametric study of hot water storage for peak power generation.

Journal of Engineering for Power 100:229-234.

315 Li, W.H.

1954 Interaction between well and aquifer.

Proceedings, American Society of Civil Engineers. 80(578):1-14.

1851 Libowitz, G.G.

1974 Metal Hydrides for Thermal Energy Storage. Ninth Intersociety Energy Conversion Engineering Conference. $322-325$.

1093 Libowitz, G.G. and Z. Blank.

1976 An Evaluation of the use of metal hydrides for solar thermal energy storage.

11 th Intersociety Energy Conversion Engineering Conference. $1: 673-680$.

1438 Lichtler, W.F., D.I. Stannard and E. Kouma.

1979 Artificial-Recharge Investigations Near Aurora, Nebraska: 2-Year Progress Report.

U.S. Geological Survey, Arlington. Open-File Report 79-1492. 58 pp.

713 Lidorenko, N.S., G.F. Muchnik, S.D. Solomonov, and A.R. Gordon.

1974 New method for investigating the permeability of porous materials.

Teplofizika Vysokikh Temperatur 12(5):1085-1090.

316 Lienau, P.J.

1977 Utilization of Geothermal Energy in Iceland.

Oregon Institute of Technology, Klamath Falls. 28 pp.

1978 Agribusiness Geothermal Energy Utilization Potential of Klamath and Snake River Basins, Oregon.

Oregon Institute of Technology, Geo-Heat Utilization Center, Klamath Falls. $10 \mathrm{pp}$. 
786 Lienau, P.J.

1978 Agribusiness Geothermal Energy Utilization Potential of Klamath and Western Snake River Basins, Oregon: Final Report.

Oregon Institute of Tech., Geo-Heat Utilization Center and Oregon Dept. of Geology and Mineral Industries. $183 \mathrm{pp}$. ID0/1621-1.

317 Lienau, P.J. and J.W. Lund.

1976 Utilization and Economics of Geothermal Space Heating in Klamath Falls, Oregon.

Oregon Institute of Technology. Geo-Heat Utilization Center, Klamath Falls. $10 \mathrm{pp}$.

624

1974 Multipurpose Use of Geothermal Energy: Proceedings of the Int'1 Conf. on Geothermal Energy for Industrial, Agricultural, and Commercial-Residential Uses.

Oregon Institute of Technology, Geo-Heat Utilization Center, Klamath Falls. 239 pp.

1482y Lienau, P.J., J.W: Lund, G.G. Culver and C.V. Higbee.

1980 Klamath Falls district heating network.

Energy to the 21st Century: 15th Intersociety Energy Conversion Engineering Conference, Seattle, WA, August 18-22. 1:156-161.

1265 Lilleleht, L.U., L.M. Fafarman, and J.T. Beard.

1978 Earth-conducted heat losses from thermal storage systems. Winter Annual Meeting of the American Society of Mechanical Engineers. 41-44.

$1193 \mathrm{~g}$ Lilleleht, L.U., L.M. Fafarman and J.T. Beard.

1978 Earth-conducted heat losses from thermal storage systems. pp. 41-50 in Thermal Storage and Heat Transfer in Solar Energy Systems, American Society of Mechanical Engineers, New York.

1360q Lin, E.I.H., W.T. Sha and A.E. Michaels.

1979 On thermal energy storage efficiency and the use of COMMIX-SA for its evaluation and enhancement.

Proceedings of Solar Energy Storage Options, San Antonio, TX, March 19-20. 1:501-514. CONF-790328-P2.

1785bs Lin, E.I.H., W.T. Sha and S.L. Soo.

1980 Technical and economic feasibility of solar ponds. Systems Simulation and Economics Analysis Conference, San Diego, January 23-25. 425-429. SERI/TP-351-431.

318 Lindemuth, T.E., E.H. Houle, S.H. Suemoto, and V.C. Van Der Mast.

1976 Experience in Scale Control with East Mesa Geothermal Brine. Society of Petroleum Engineers, Dallas. 173-186. SPE-6605.

319 Lindorff, D.E.

1979 Ground water pollution: a status report.

Ground Water 17(4):9-17. 
714 Lindroth, D.P.

1974 Thermal Diffusivity of Six Igneous Rocks at Elevated Temperatures and Reduced Pressures.

U.S. Department of Interior, Bureau of Mines, Washington. $33 \mathrm{pp}$. RI-7954.

1094 Lior, N.P., S. Ayyaswamy, J. O'Leary, K.W. Kauffman, and H. Yeh.

1976 Thermal Energy Storage Considerations for Solar-Thermal Power Generation.

11 th Intersociety Conversion Engineering Conference, September 1976. 1:613-622.

320 Lippmann, M.J.

1976 Thermal Energy Storage in Aquifers: Analytical Modeling at LBL. Lawrence Berkeley Laboratory, Berkeley, CA.

322 Lippmann, M.J., C.F. Tsang, and P.A. Witherspoon.

1977 Analysis of the Response of Geothermal Reservoirs Under Injection and Production Procedures. Society of Petroleum Engineers, Dallas. 15 pp. SPE-6537.

1177ak Lippmann, M.J., C.F. Tsang and P.A. Witherspoon.

1978 Study of groundwater temperature changes during aquifer uses related to power production. Pages 135-138 in Earth Sciences Division Annual Report, Lawrence Berkeley Laboratory, Berkeley, CA. LBL-8648.

1177af Lippmann, M.J., G.S. Bodvarsson and P.A. Witherspoon.

1978 Preliminary simulation studies related to the Cerro Prieto field. Pages 111-118 in Earth Sciences Division Annual Report, Lawrence Berkeley Laboratory, Berkeley, CA. LBL-8648.

1177 ae Lippmann, M.J., P.A. Witherspoon and H.A. Wollenberg.

1978 Mexican-American cooperative program at the Cerro Prieto geothermal field, Baja California, Mexico. Pages 106-110 in Earth Sciences Division Annual Report, Lawrence Berkeley Laboratory, Berkeley, CA. LBL-8648.

321 Lippmann, M.J., T.N. Narasimhan, and P.A. Witherspoon.

1977 Modeling Subsidence Due to Geothermal Fluid Production. American Society of Civil Engineers. 25 pp. Preprint 3107.

1527 Lippmann, M.J. and C.F. Tsang.

1980 Ground water use for cooling: associated aquifer temperature changes. Ground Water 18(5): 452-458.

717 Lo, H.Y. and N. Mungan.

1973 Effect of Temperature on Water-0il Relative Permeabilities in 0il-Wet and Water-Wet Systems. 
Society of Petroleum Engineers of AIME, Dallas. 12 pp. SPE-4505.

960 Locke, F.E., L.B. Owen, and R. Quong.

1979 Lawrence Livermore Laboratory Test Facilities at the Salton Sea Geothermal Field, Southern California.

Lawrence Livermore Laboratory, Livermore, CA. 13 pp. UCRL-83428.

1431 Loddo, M.

1970 Temperature in an insulated slab heated by a plane source: application to thermal conductivity measurements of rocks. UN Symposium on the Development and Utilization of Geothermal Resources, in Geothermics 2(1):437-442.

570 Lofgren, B.E.

1961 Measurement of compaction of aquifer systems in areas of 1 and subsidence.

pp. B49-B52 in U.S. Geological Survey, Arlington. Professional Paper 424-B.

571

1969 Field measurement of aquifer-system compaction, San Joaquin Valley, CA.

USA Proceedings Tokyo Symposium on Land Subsidence. IASH/AIHS Unesco. 272-284.

1194

1973 Monitoring ground movements in geothermal areas.

Hydraulic Engineer and Environment Proceedings, Hydraulic Div. Speciality Conf. ASCE, Bozeman, MT. 437-447.

1693

1960 Near-surface land subsidence in Western San Joaquin Valley, California. Journal of Geophysical Research 65(3):1053-1062.

779 Lohman, S.W.

1972 Ground-Water Hydraulics.

U.S. Geological Survey, Arlington. Professional Paper 708. 70 pp.

1025 Lohse, D. and G. Taft.

1975 Put compressor waste heat to work. Power $119(8): 34-35$.

1095 Lorsch, H.G.

1975 Thermal energy storage for solar heating. ASHRAE Journal Nov:47-52.

1980 Survey of thermal storage installations in the United States and Canada.

Proceedings of the DOE Thermal and Chemical Storage Annual Contractors' Review Meeting. 44-45. 
1852 Lorsch, H.G.

1974 Thermal Energy Storage Devices Suitable for Solar Heating. Ninth Intersociety Energy Conversion Engineering Conference. 572-577.

1844 Lorsch, H.G., K.W. Kauffman and J.C. Denton.

1975 Thermal energy storage for solar heating and off-peak air conditioning.

Energy Conversion 15:1-8.

1315h Lorsch, H.G. and K.W. Kauffman.

1979 Central storage for solar active space heating. Proceedings of Solar Energy Storage Options, San Antonio, TX. March 19-20. 1:85-96. CONF-790328-P1.

1910 Lorsch, H.G. and M.A. Baker.

1981 Survey of commercial thermal storage installations in the United States and Canada. Technical and Economic Analysis Meeting, Chicago, April 22.

1149 Los Alamos Scientific Laboratory.

1974 Proceedings of the First National Topical Meeting on Nuclear Process Heat Applications. Los Alamos Scientific Laboratory, Los Alamos, NM. 276 pp. CONF -741032.

1432 Loscutoff, W.V.

1980 Compressed Air Energy Storage Technology Program: Annual Report for 1979.

Pacific Northwest Laboratory, Battelle, Richland, WA. 168 pp. PNL-3395.

323 Louden, L.R. and R.E. McGlothl in.

1979 Waste water base drilling fluid disposal. pp. 515-522 in Environmental Aspects of Chemical Use in Wel1-Drilling Operations, U.S. EPA. EPA-560/1-75-00HC1975.

1692 Lovering, T.S.

1936 Heat conduction in dissimilar rocks and the use of thermal models.

Bulletin of the Geological Society of America 47:87-100.

324 Loy, S.E.

1975 Techniques of deep well drilling. pp. 11-25 in Environmental Aspects of Chemical Use in We11-Drilling Operations, U.S. EPA. EPA-560/1-75-004.

1740 Ludwig, N.C. and S.A. Pence.

1956 Conduction calorimeter for measuring heat of hydration of Portland cement at elevated temperatures and pressures. Journal of American Concrete Institute 27(6):173-184. 
718 Luikov, A.V.

1976 Capillary-porous materials and the transfer of heat or energy. International Chemical Engineer 16(1):54-60.

1398 Lummus, J.L.

1969 Factors to be considered in drilling optimization. pp. 100-110 in Drilling Production and Practice, American Petroleum Institute.

325 Lund, J.W.

1978 Geothermal Energy Utilization for the Homeowner. Oregon Institute of Technology, Geo-Heat Utilization Center, Klamath Falls. $30 \mathrm{pp}$.

326 Lund, J.W., G.G. Culver, S. Doyle, P.J. Lienau, A. Rathmacher, and L.S. Svanevik.

1978 Geothermal Hydrology and Geochemistry of Klamath Falls, Oregon Urban Area. Oregon Institute of Technology, Geo-Heat Utilization Center, Klamath Falls.

327 Lund, J.W., P.J. Lienau, G.G. Culver, and C.V. Higbee.

1977 Klamath Falls Geothermal Heating District.

LLC Geothermal Consultants, Klamath Falls, OR. 16 pp.

1026 Lundberg, W.L. and F. Wojnar.

1979 Applications of Thermal Energy Storage to Waste Heat Recovery in the Food Processing Industry.

American Chemical Society, Washington, DC. 481-486.

1144 Lundberg, W.L. and J.A. Christenson.

1979 Applications of Thermal Energy Storage to Waste Heat Recovery in the Food Processing Industry: Final Report. Westinghouse Electric Corporation, Pittsburgh, PA. 134 pp. ORNL/SUB $-79 / 42532$.

328 Lundstrom, L. and H. Stille.

1978 Large Scale Permeability Test of the Granite in the Stripa Mine and Thermal Conductivity Test.

Swedish Nuclear Fuel Safety Program, Stockholm. 33 pp. LBL-7052, SAC-02.

329 Lynch, E.J. and E.A. Breitenbach.

1964 Recent developments in formation evaluation. World 0i1 158:110-118.

1582 MCC Associates, Inc.

1980 Mechanical, Magnetic, and Underground Energy Storage 1980 Annual Contractors' Review, Washington, November 10-13. MCC Associates, Inc. CONF-801128. 
1581 MCC Associates, Inc.

1980 Project Summary Data: Mechanical, Magnetic, and Underground Energy Storage Program. MCC Associates, Inc. 81 pp. DOE/TIC-11276.

1315d MacCracken, C.D.

1979 Phase change materials for thermal storage of solar-electric heat pump combinations. Proceedings of Solar Energy Storage Options, San Antonio, TX. March 19-20. 1:41-50. CONF-790328-P1.

1196 Maclay, R.W. and G.R. Schiner.

1962 Aquifers in buried shore and glaciofluvial deposits along the Gladstone Beach of Glacial Lake Agassiz Near Stephen, Minnesota. Paper 450-D, pp. 170-172 in U.S.G.S. Research, Short Papers in Geology, Hydrology, and Topography, Articles 120-179, U.S.G.S.

330 Maddock, T.

1976 A Drawdown prediction model based on regression analysis. Water Resources Research 12(4):818-822.

331 Madhav, M.R. and P. Basak.

1977 Ground subsidence due to nonlinear flow through deformable porous media. Journal of Hydrology $34(1-2): 21-33$.

1096 Magnuson, E.E.

1975 Fuel Conservation in Forging Industry Through Heat Recovery. Industrial Heating May:26-32.

$1177 j$ Majer, E.L. and T.V. McEvilly.

1978 Seismological studies at Cerro Prieto. pp. 29-33 in Earth Sciences Division Annual Report, Lawrence Berkeley Laboratory, Berkeley, CA. LBL-8648.

9999cw Malcolm, R.L., G.R. Aiken, E.M. Thurman and P.A. Avery.

1980 Hydrophilic organic solutes as tracers in groundwater recharge studies.

Contam Sediments 2:71-88.

9999cx Mallow, W.A.

1976 Hydrothermal cement and a method of cementing a string of pipe in a bore hole. Patent \# 1572174, App1ication \# 76/31830. Southwest Research Institute.

782 Malofeev, G.E.

1960 Calculation of the temperature distribution in a formation when pumping hot fluid into a well. Neft i Gaz 3(7):59-64. 
1676 Maly, G.P.

1980 Methods of Increasing the Permeability of Subterranean Reservoirs. U.S. Patent \# 4194566. 7 pp.

333 Manahan, S.E.

1976 Information Dissemination in the Water Resources Field. University of Missouri, Columbia, Missouri Water Resources Research Center. 43 pp. PB-260 486.

1197 Mangold, D.C., C.F. Tsang, M.J. Lippmann, and P.A. Witherspoon. 1979 A Study of Thermal Effects in Well Test Analysis. Lawrence Berkeley Laboratory, Berkeley, CA. 12 pp. LBL-9769.

1673 Manson, C. (compiler).

1980 Theses on Washington Geology: A Comprehensive Bibliography, 1901-1979.

State of Washington, Department of Resources, Olympia, WA. 212 pp. Information Circular 70.

1528 Mansure, A.J.

1979 Feasibility study of a small pumped aquifer storage system for solar and wind energy.

Proceedings of the Mechanical and Magnetic Energy Storage Contractors' Review Meeting, Washington, Aug. CONF-790854. 296-302.

1544af Manvi, R.

1980 Dish-mounted latent heat buffer storage. Proceedings of the DOE Thermal and Chemical Storage Annual Contractors' Review Meeting. 123-127.

13830 Mar, R.W.

1980 Sandia Laboratories in-house activities in support of solar thermal large power applications.

Thermal Energy Storage: Fourth Annual Review Meeting, Tysons Corner, VA, Dec. 3-4, 1979. 157-162. CONF-791232.

334 Margen, $P$.

1978 The Use of nuclear energy for district heating. Progress in Nuclear Energy 2:1-28.

919

1978 A Hot-Water Reservoir for Long-Term Storage.

Aktie Bolaget Atomemergi AE-E-209. 1978-01-02.

957 Margen, P., B. Perers, and K.G. Spangberg.

1979 Central solar heat stations for 2000 existing and new dwellings: the Linkoping (Malmslatt) Study.

UNICHAL Congress, Stockholm, May 13-18. $25 \mathrm{pp}$. 
1027 Margen, P.H.

1972 Thermal energy storage in rock chambers: a complement to nuclear power.

Proceedings of the Fourth International Conference on the Peaceful Uses of Atomic Energy, Geneva, Sept. 6-16.

$4: 177-194$.

1473 Margen, P.H. and R. Roseen.

1979 Solar heat for small district heating systems. The International Total Energy Congress, Copenhagen, Denmark, October 8-12, 1979. $13 \mathrm{pp}$.

1028 Marianowski, L.G. and H.C. Maru.

1977 Latent heat thermal energy storage systems above $450 \mathrm{C}$. 12 th Intersociety Energy Conversion Engineering Conference. $2: 555-566$.

335 Marine, I.W.

1975 Water level fluctuations due to earth tides in a well pumping from slightly fractured crystalline rock. Water Resources Research 2(1):165-171.

1482 ao Marks, S.B.

1980 Thermal energy storage using Glauber's salt: improved storage capacity with thermal cycling.

Energy to the 21st Century: 15th Intersociety Energy Conversion Engineering Conference, Seattle, WA, August 18-22. $1: 259-261$.

719 Marovelli, R.L. and K.F. Veith.

1965 Thermal Conductivity of Rock: Measurement by the Transient Line Source Method.

U.S. Department of Interior, Bureau of Mines. $19 \mathrm{pp}$. RI -6604 .

1691 Marsden, S.S. and S.N. Davis.

1967 Geological subsidence.

Scientific American 216(6):93-100.

1193j Marshal1, R.H.

1978 Natural convection effects in rectangular enclosures containing a phase change material.

pp. 61-70 in Thermal Storage and Heat Transfer in Solar Energy Systems, American Society of Mechanical Engineers, New York.

1544b Martin, J.F.

1980 ORNL Thermal Energy Storage Program overview. Proceedings of the DOE Thermal and Chemical Storage Annual Contractors' Review Meeting. 3-6. 
1447 Martin, J.F. and H.W. Hoffman.

1980 Thermal Energy Storage for Building Heating and Cooling Applications: iechnical Progress Report for Period April 1979-March 1980.

Oak Ridge National Laboratory, Oak Ridge, TN. 62 pp. ORNL/TM-7319.

1416 Martin, W.L., J.N. Dew, M.L. Powers, and H.B. Steves.

1968 Results of a tertiary hot waterflood in a thin sand reservoir. pp 99-110 in Thermal Recovery Techniques, Society of Petroleum Engineers of AIME, Dallas.

1029 Martinez, R.H. and J.M. Henry.

1979 Multiple Boiler Scheduling for Energy Conservation. American Chemical Society, Washington, DC. 1630-1634.

336 Marx, J.W. and R.H. Langenheim.

1959 Reservoir heating by hot fluid injection.

Petroleum Transactions, AIME 216:312-315.

1690 Mashiko, Y. and Y. Hirano.

1970 New supply systems of thermal waters to a wide area in Japan. U.N. Symposium on the Development and Utilization of Geothermal Resources 2(2):1592-1595.

720 Mather, J.D., D.A. Greenwood, and P.B. Greenwood.

1979 Burying Britain's radioactive waste: the geological areas under investigation.

Nature 281:332-333.

337 Mathey, B.

1975 Le Stockage thermique dans les nappes souterraines. Symposium de la Societe Suisse Pour L'Energie Solaire, Lousanne, Suisse. 9 Juin. 62-72.

1977 Development and resorption of a thermal disturbance in a phreatic aquifer with natural convection. Journal of Hydrology $34: 315-333$.

569 Mathey, B., E. Recordon, and B. Saugy.

1977 Etude des transferts de masse et de chaleur dans les Nappes Souterraines. Wasser, Energie Luft. -Eau, Energie, Air 69(11-12):289-296.

339 Mathey, B. and A. Menjoz.

1977 Transferts de chaleur en mileu heterogene sature: comparaison des resultats analytiques et numeriques avec les resultats experimentaux in situ. Symposium on Hydrodynamic Diffusion and Dispersion in Porous Media. 79-87. 
1261 Matthews, C.S. and D.G. Russell.

1967 Pressure Buildup and Flow Tests in Wells. Society of Petroleum Engineers of AIME, Dallas. 167 pp.

1399 Maurer, W.C.

1975 Geothermal drilling technology. Proceedings: 2nd UN Symposium on the Development and Use of Geothermal Resources, San Francisco, May 20-29. 1509-1521.

14541 Mayotte, R.J.

1980 One approach to cost of service for district heating. Official Proceedings, 71st Annual Conference of the International District Heating Assn, Harbor Springs, MI, June 23-25. Sec 18.

1363 McCabe, J.E. and D.D. Huxtable.

1980 District heating for Bellingham, Washington: using waste heat from an aluminum plant as the energy source.

District Heating Jan-Feb-Mar:14-21.

568 McCaffey, F.G.

1976 Interfacial tensions and aging behavior of some crude oils against caustic solutions. Journal of Canadian Petroleum Technology 15(3):71-74.

349 McCain, W.D. and J.D. Stacy.

1971 A Method of correlation of high-temperature, high-pressure gas-solid adsorption data. Society of Petroleum Engineers Journal 11:4-6.

1629 McConne 11, T.D.

1980 Pressure instrumentation for geothermal borehole logging. Geothermal Resources Council Annual Meeting, Salt Lake City, September $9.4 \mathrm{pp}$.

721 McCuen, R.H. and L.E. Asmussen.

1973 Estimating the effect of heat storage on evaporation rates. Hydrological Sciences Bullet in 28(26):191-196.

340 McCune, C.C.

1977 On-site testing to define injection-water quality requirements. Journal of Petroleum Technology 29:17-24.

1097 McDonald, C.F. and D.L. Vrable.

1976 Component design considerations for gas turbine HTGR Waste-Heat Power Plant. 11th Intersociety Energy Conversion Engineering Conference. $1: 613-622$.

341 McDonald, C.L. and C.H. Bloomster.

1977 The GEOCITY Mode l: Description and Application. Pacific Northwest Laboratory, Battelle, Richland, WA. 43 pp. BNWL-SA-6343. 
1132 McDonnel1 Douglas Astronautics Company.

1977 Industrial Applications of Solar Total Energy: Final Report. McDonnell Douglas Astronautics Company, Huntington Beach, CA. Vol. 2. 222 pp. SAN/1132-2/2.

$1177 f$ McEviliy, T.V., B. Schechter and E.L. Majer.

1978 Geothermal seismic field system development.

Pages 15-19 in Earth Sciences Division Annual Report, Lawrence Berkeley Laboratory, Berkeley, CA. LBL-8648.

$1177 i$

1978 East Mesa seismic study.

Pages 26-28 in Earth Sciences Division Annual Report, Lawrence Berkeley Laboratory, Berkeley, CA. LBL-8648.

342 MCFarland, C.R.

$19790 i 1$ and Gas Exploration in Washington, 1900-1978.

Washington (State) Department of Natural Resources, Division of Geology and Earth Resources. 119 pp. Information Circular 67.

13150 McGarity, A.E.

1979 Optimum collector-storage combinations involving annual cycle storage.

Proceedings of Solar Energy Storage Options, San Antonio, TX. March 19-20. 1:165-174. CONF-790328-P1.

722 McGaw, R.

1969 Heat Conduction in Saturated Granular Materials.

U.S. Army Terrestrial Sciences Center, Hanover, NH. 114-131.

343 McLean, G.0.

1955 The Dual-purpose domestic heat pump. Journal of the Institute of Fuel 28:224-228.

921 McMillion, L.G.

Bull Session 4 - Aquifer Protection and Rehabilitation.

344 McNabb, J.F. and W.J. Dunlap.

1975 Subsurface biological activity in relation to ground-water pollution.

Ground Water 13(1):33-44.

918 Meehan, D.N., D.E. Menzie, and H.B. Crichlow.

1978. A Laboratory study of water immobilization for improved oil recovery.

Journal of Petroleum Technology 28:205-209.

345 Megley, J.W.

1968 Heat pumps provide economical services for apartment tenants. Heating, Piping and Air Conditioning 40(1):124-131. 
346 Megley, J.W. and G.W. McElhaney.

1970 Energy requirements: summary and analys is of results. ASHRAE Symposium on Heat Pumps: Improved Design and Performance. 20-29.

347 Meinzer, O.E.

1928 Compressibility and elasticity of artesian aquifers. Economic Geology 23:263-291.

1424 Mercado, S. Scaling in Geothermal Wells. IIE Energy Sources Division, Piso, Mexico. 6 pp.

348 Mercer, J.W., G.F. Pinder and I.G. Donaldson.

1975 A Galerkin-finite element analysis of the hydrothermal system at Wairakei, New Zeal and.

Journal of Geophysical Research 80(17):2608-2621.

1560 Mercer, J.W., S.P. Larson and C.R. Faust.

1980 Simulation of salt-water interface motion. Ground Water 18(4):374-385.

835 Mercer, J.W. and C.R. Faust.

1979 Geothermal reservoir simulation: 3. application of liquid-and vapor-dominated hydrothermal modeling techniques to Wairakei, New Zealand.

Water Resources Research 15(3):653-671.

1975 Simulation of Water - and Vapor Dominated Hydrothermal Reservoirs. Society of Petroleum Engineers of AIME, Dallas. 16 pp. SPE 5520.

1558

1980 Ground-water modeling: an overview.

Ground Water 18(2):108-115.

1559

1980 Ground-water modeling: mathematical models. Ground Water 18(3):212-227.

1980 Ground-water modeling: applications. Ground Water 18(5):486-497.

1979 A review of numerical simulation of hydrothermal systems. Hydrological Sciences Bulletin 24(3.9):335-343.

1980 The Physics of fluid flow and heat transport in geothermal systems.

pp. 121-135 in J. Kestin, ed., The Sourcebook on the Production 
of Electricity from Geothermal Energy. DOE/RA/4051-1.

1493 Messer, P.H., D.S. Pye and J.P. Gallus.

1978 Injectivity restoration of a hot-brine geothermal injection we 11 . Journal of Petroleum Technology 30:1225-1230.

1030 Metz, P.D.

1978 Energy storage and solar power: an exaggerated problem. Science 200:1471-1473.

$1315 c$

1979 The State of the art of sensible heat storage for solar source heat pump systems.

Proceedings of Solar Energy Storage Options, San Antonio, TX. March 19-20. 1:31-40. CONF-790328-P1.

1716

1980 Ground Coupled Solar Heat Pump Research Program in the United States.

Brookhaven National Laboratory, Upton, NY. 4 pp. BNL-27383.

9999ef

1979 Experimental results from the solar ground coupling research facility at Brookhaven National Laboratory.

Sun 2: Proceedings of the International Solar Energy Society Silver Jubilee Congress, Atlanta, GA, May 1979. 1:604-608.

350 Meyer, A.F.

1960 Effect of temperature on ground-water levels. Journal of Geophysical Research 65(6):1747-1752.

351 Meyer, C.F.

1973 Are heat-storage wells the answer?

Electrical World 180(4):42-45.

352

1976 Status report on heat storage wells.

Water Resources Bulletin 12(2):237-252.

353

1977 Heat storage wells: key to large-scale cogeneration?

Public Power Jul-Aug:28-30.

354

1978 Evaluation of thermal energy storage for the proposed Twin Cities District Heating System.

Third Annual Thermal Energy Storage Contractors' Information Exchange Meeting. 9 pp.

1978 Large Scale Thermal Energy Storage for Congeneration and Solar Systems.

GE Tempo, Santa Barbara, CA. 12 pp. P-785. 
877 Meyer, C.F.

1979 Potential Benefits of Thermal Energy Storage in the Proposed Twin Cities District Heating - Cogeneration System. GE Tempo, Santa Barbara, CA. ORNL/SUB-7604-1.

$1383 \mathrm{ad}$

1980 Evaluation of thermal energy storage for the proposed Twin Cities district heating system.

Thermal Energy Storage: Fourth Annual Review Meeting, Tysons Corner, VA, Dec. 3-4, 1979. 283-296. CONF-791232.

1722

1979 Seasonal Storage Facility for the Canadian Central Receiver Solar Utility Concept: A Brief Review of Requirements, Candidates, and Choices. General Electric, Tempo, Santa Barbara, CA. 70 pp. GE79TMP-76.

1539 Meyer, C.F. (ed).

1979 Evaluation of thermal energy storage for a large urban hot water district heating system in the United States. GE Tempo, Center for Advanced Studies, Santa Barbara, CA. CONF-7910152-1. (Draft).

361 Meyer, C.F., D.K. Todd and R.C. Hare.

1972 Thermal Storage for Eco-Energy Utilities. GE Tempo, Santa Barbara, CA. GE72TMP-56.

357 Meyer, C.F., W. Hausz, B.L. Ayres and H.M. Ingram.

1976 Role of the Heat Storage Well in Future U.S. Energy Systems. GE Tempo, Santa Barbara, CA. GE76TMP-27A.

363 Meyer, C.F., and W. Hausz.

1975 A New Concept in Electric Generation and Energy Storage. GE Tempo, Santa Barbara, CA.

358 Meyer, C.F. and D.K. Todd.

1973 Conserving energy with heat storage wells. Environmental Science and Technology 7(6):512-516.

1973 Heat-storage wells: an answer to energy conservation and thermal pollution?

Water We11 Journal 27:35-41.

1973 Heat-storage wells for conserving energy and reducing thermal pollution.

8th Intersociety Energy Conversion Engineering Conference. 5 pp.

1974 Brunnen als warmespeicher eine moglicheit, energie zu sparen und thernische umweltbelastung zu verhuten? 
Braunkohle 26(9):275-280.

356 Meyer, C.F. and W. Hausz.

1978 Energy management objectives and economics of heat storage wells. Thermal Energy Storage in Aquifers Workshop. GE Tempo. P-803.

1510

1980 Guidelines for Conceptual Design and Evaluation of Aquifer Thermal Energy Storage Systems. GE Tempo, Santa Barbara, CA. GE80TMP-44. PNL-3581.

362 Meyer, W.R.

1962 Use of a neutron moisture probe to determine the storage coefficient of an unconfined aquifer. pp. E174-E176 in U.S. Geological Survey Research, U.S. Geological Survey, Arlington. Professional Paper 450.

1226 Meysenburg, $\mathrm{H}$.

1974 Das Speicherproblem und die Energiekrise, [Storage problems and the energy crisis].

VDI-Berichte 223:5-6.

364 Michaels, A.I.

1979 IEA/CRD/Solar Heating and Cooling Systems: Annex VI - Central Solar Heating Plant with Seasonal Water Storage, Feasibility Study and Design.

IEA/CRD/ Solar Heating and Cooling Systems, Studsvik, Sweden, Jan. 24-25, 1979. (Revised Draft).

1590

1980 An Overview of the U.S.A. Program for the Development of Thermal Energy Storage for Solar Energy Applications. Argonne National Laboratory, Argonne, IL. 11 pp.

1671

1980 Foreign Trip Report: Amsterdam, The Netherlands, November $3-7,1980$.

Argonne National Laboratory, Argonne, IL.

1031 Miche1, J.W.

1970 The Agro-Industrial Complex. Oak Ridge National Laboratory, Oak Ridge, TN. SM-113/32. pp. $713-744$.

1779 Mid-Continent District Study Committee on Cementing Practices and Testing of $0 i 1$-Well Cements.

1954 Effects of high pressures and temperatures on strength of oil-wel1 cements.

The Mid-Continent Dist. Study Committee on Cementing Practices and Testing of 0il-We11 Cements, Spring Mt, API, Ok1ahoma City. 
1115 Midwest Research Institute.

1977 Application of Solar Energy to Industrial Drying or Dehydration Processes: Final Report.

Midwest Research Institute, Kansas City, M0. 49 pp. ORO/5121-1.

1736

1981 Thermal energy storage: its importance in energy conservation. Viewpoint Winter:12-13.

365 Milburn, H.L.

1964 Computerizing heat pump operating costs. Journal of ASHRAE 6(8):67-71.

594 Miles, C.R.

1978 Modeling and Flow Measurement of Shallow Geothermal Systems with Downhole Heat Exchangers.

M.S. Thesis, Oregon State University, Corvallis. 64 pp.

566 Millard, V., N.G. Berndtsson, and J.A. Bray.

1976 Current and required economics in relation to further Alberta enhanced recovery of conventional crude. Journal of Canadian Petroleum Technology 15(3):20-31.

366 Miller, C.W.

1979 A Numerical Model of Transient Two Phase Flow in a Geothermal Wel1. Lawrence Berkeley Laboratory, Berkeley, CA. 4 pp. LBL -9056.

367 Miller, C.W. and J.M. Zerzan.

1979 Downhole Pressure Changes Measured with a Fluid Filled Capillary Tube. Lawrence Berkeley Laboratory, Berkeley, CA. LBL-9303.

1564 Miller, I. and K. Roman.

1979 Numerical Modeling of Solute Transport in Groundwater. Golder Associates, Inc. UCRL 15179.

565 Miller, R.E.

1961 Compaction of an aquifer system computed from consolidated tests and decline in artesian head.

pp. B54-B58 in U.S. Geological Survey Research 1961, Articles 1-146. U.S. Geologic Survey, Arlington. Professional Paper 424B.

1482bx Miller, R.L.

1980 Corrosion and materials selection for geothermal systems. Energy to the 21st Century: 15th Intersociety Energy Conversion Engineering Conference, Seattle, WA, August 18-22. 1:460-464.

1315y Mi11s, L.G. and H.E. Remmers.

1979 Heat pump/rock bed storage systems.

Proceedings of Solar Energy Storage Options, San Antonio, TX. 
March 19-20. 1:251-260. CONF-790328-P1.

564 Milora, S.L. and J.W. Jefferson.

1976 Geothermal Energy as a Source of Electrical Power. MIT Press, Cambridge. $186 \mathrm{pp}$.

724 Minkowycz, W.J. and P. Cheng.

1976 Free convection about a vertical cylinder embedded in a porous medium.

International Journal of Heat and Mass Transfer 19:805-813.

9999dy Minnesota Energy Agency.

Minnesota Project: District Heating and Cooling Through Power Plant Retrofit and Distribution Network, Final Report-Phase 1. Minnesota Energy Project, St. Pau1. 146 pp. C00-4980-1.

1358 Minor, J.E.

1980 Seasonal Thermal Energy Storage Program:Progress Report Apri1 1979 - December 1979.

Pacific Northwest Laboratory, Battelle, Richland, WA. 47 pp. PNL -3322 .

1145 Mitche11, P.D., B.P. Gupta, K.L. Curtner, and R.A. Rausch.

1977 Textile Drying Using Solarized Cylindrical Can Dryers to Demonstrate the Application of Solar Energy to Industrial Drying or Dehydration Processes. Honeywel1 Incorporated, Minneapolis, MN. 0R0/5124-1.

1177y Mlodinow, L.D. and C.F. Tsang.

1978 Effect of radially varying transmissivity on the transient pressure phenomenon.

Pages 75-76 in Earth Sciences Division Annual Report, Lawrence Berkeley Laboratory, Berkeley, CA. LBL-8648.

557 Moesta, $H$.

1972 Heizen, Kuhlen durch Sonne und Weltraum, [Heating, Cooling through the Sun and Space].

Umwe 1t, Jun:53-58.

1312 Molz, F.J., A.D. Parr, P.F. Andersen and V.D. Lucido.

1979 Thermal energy storage in a confined aquifer: experimental results. Water Resources Research 15(6):1509-1514.

626 Molz, F.J., A.D. Parr, P.F. Andersen, V.D. Lucido, and J.C. Warman.

1979 Thermal Energy Storage in Confined Aquifers. Water Resources Research Institute, Auburn University. $29 \mathrm{pp}$. (Preprint).

1032 Molz, F.J., A.D. Parr, and P.F. Andersen.

1979 Thermal Energy Storage in Aquifers: Experimental Study. American Chemical Society, Washington, DC. 534-537. 
1359 Molz, F.J., A.D. Parr and P.F. Andersen.

1980 Experimental Study of the Storage of Thermal Energy in Confined Aquifers: Final Report for the Period July 1, 1977 to December $31,1979$.

Oak Ridge National Laboratory, Oak Ridge, TN. 46 pp. ORNL/Sub/7338/1.

371 Molz, F.J., J.C. Warman, T.E. Jones and G.E. Cook.

1976 Experimental study of the subsurface transport of water and heat as related to the storage of solar energy.

Sharing the Sun: Solar Tech. in the 70's. Jt Conf Am Sec Int'1 Solar Energy Soc and Solar Energy Soc of Canada, Inc. 8:238-244.

370 Molz, F.J., J.C. Warman and T.E. Jones.

1978 Aquifer storage of heated water: Part 1. a field experiment. Ground water 16(4):234-241.

369 Molz, F.J. and J. Warman.

1978 Aquifer storage of heat.

Water Well Journal 22(2):46-47.

368 Molz, F.J. and L.C. Bell.

1977 Head gradient control in aquifers used for fluid storage. Water Resources Research 13(4):795-798.

1033 Moore, G.L.

1974 Sizing of Solar Energy Storage Systems Using Local Weather Records.

American Society of Mechanical Engineers, New York. 74-WA/HT-20.

372 Morey, G.W., R.0. Fournier and J.J. Rowe.

1962 The Solubility of quartz in water in the temperature interval from 25 to $300 \mathrm{C}$.

Geochimica et Cosmochimica Acta 26:1029-1043.

1741 Morgan, B.E. and G.K. Dumbauld.

1952 Measurement of the permeability of set cement. Journal of Petroleum Technology June:16-17.

1331 Morgan, M.T., and G.A. West.

1980 Thermal Conductivity of the Rocks in the Bureau of Mines

Standard Rock Suite.

Oak Ridge National Laboratory, Oak Ridge, TN. 54 pp.

ONRL/TM-7052.

1418 Mori, Y. and W. Nakayama.

1967 Study on forced convective heat transfer in curved pipes: 2nd report, turbulent region.

International Journal of Heat and Mass Transfer 10:37-59. 
1034 Moriarty, M.P.

1979 A Simplified Algorithm for the Evaluation of Hybrid Thermal Storage with Water Systems.

American Chemical Society, Washington, DC. 521-527.

1651

1978 Hybrid Thermal Storage With Water: Semi Annual Progress Report for the Period September 1, 1977 to May 15, 1977.

Rockwell International Corporation and Atomics International Corporation, Canoga Park, CA. 105 pp. C00-4480-T1.

1198 Morrell, G.0. and R.E. Collins.

1978 Depth constraints on thermal storage wells. Second Invitational We11-Testing Symposium Proceedings. CONF-7810170. 108-111.

1177e Morrison, H.F., N.E. Goldstein, M. Hoversten, G. Oppliger and C. Riveros.

1978 Controlled-source electromagnetic system.

Pages 12-14 in Earth Sciences Division Annual Report, Lawrence Berkeley Laboratory, Berkeley, CA. LBL-8648.

768 Moseley, J.C. and J.F. Malina, Jr.

1968 Relationships Between Selected Physical Parameters and Cost Responses for the Deep-We 11 Disposal of Aqueous Industrial Wastes.

University of Texas at Austin, Center for Research in Water Resources. $276 \mathrm{pp}$. CRWR 28.

563 Moses, T.H., Jr. and J.H. Sass.

1979 Driliing Techniques Presently in Use by the Geothermal Studies Project.

U.S. Geological Survey, Arlington. $26 \mathrm{pp}$. Open File Report $79-763$.

373 Moss, J.T. and P.D. White.

1959 How to calculate temperature profiles in a water-injection well. $0 i 1$ and Gas Journal 57(11):174-178.

1087 Mother Earth News.

1978 Joseph Orr's fabulous 'Mud Heat Storage' solar greenhouse. Mother Earth News May-Jun:94-97.

1791 Motovilov, Y.G.

1978 Mathematical model of water infiltration into frozen soil. Soviet Hydrology $17(1): 62-66$.

374 Moulder, E.A.

1970 Freshwater bubbles: a possibility for using saline aquifers to store water. Water Resources Research 6(5):1528-1531. 
562 Moulder, E.A. and D.R. Frazor.

1957 Artificial-Recharge Experiments at McDonald Well Field, Amarillo, TX.

Texas Board of Water Engineers. 34 pp. Bulletin 5701.

375 Mount, J.R.

1969 A Simplified technique for well-field design. Ground Water 7(3):5-8.

1580 Moyers, J.C. and E.C. Hise.

1977 The Annual cycle energy system concept and application.

Energy Use Management International Conference, Tucson. 231-239.

561 Mueller, R.0., J.G. Asbury, J.V. Caruso, D.W. Connor, and R.F. Giese.

1978 Optimal design of seasonal storage for $100 \%$ solar space heating in buildings.

Proceedings of AAAS Symposium: Efficient Comfort Conditioning:

Heating and Cooling of Buildings. $20 \mathrm{pp}$.

725 Mueller, T.D.

1962 Transient response of nonhomogeneous aquifers.

Society of Petroleum Engineers Journal 2:33-43.

560 Muffler, L.J.P. (ed).

1978 Assessment of Geothermal Resources of the United States - 1978.

U.S. Geological Survey, Arlington. 163 pp. Map. Circular 790.

836 Mulac, A.J., W.L. Flower, R.A. Hil1, and D.P. Aeschliman.

1977 Enhanced Spontaneous Raman Scattering Technique for Highly Luminous Environments.

1977 Fall Meeting, Western States Section, The Combustion

Institute, Oct. 17-18, Palo Alto, CA. 13 pp. SAND-77-1115c.

376 Mungan, N.

1965 Permeability reduction through changes in $\mathrm{pH}$ and salinity. Journal of Petroleum Technology 117:1449-1453.

377 Murphy, H.D.

1977 Fluid Injection Profiles: A Modern Analys is of Wellbore Temperature Surveys.

Society of Petreolem Engineers of AIME, Dal1as. 8 pp. SPE-6783.

1328 Murphy, L.M.

1979 Systems Analysis and Testing (SAT) Program: Annual Progress

Report October 1, 1978-September 30, 1979.

Solar Energy Research Institute, Golden, C0. 35 pp.

SERI/PR-351-419.

1789 Musti110, N. and A.C. de Digiacomo.

1957 Pumps.

U.S. Patent \#2,813,719. 6 pp. 
837 Mutti, D.H., J.E. Atwood, C.R. LaFayette, and A.0. Landrum.

1976 Corrosion control of gas-lift well tubulars by continuous inhibitor injection into the gas-lift gas stream. Journal of Petroleum Technology 28:624-628.

1035 Muzzy, J.D. and J.T. Sommerfeld.

1979 Novel Approaches to Industrial Energy Conservation in Georgia. American Chemical Society, Washington, DC. 1793-1798.

378 Mylander, H.A.

1953 0il field techniques for water well drilling. American Water Works Association Journal 45:764-772.

1506 NASA Lewis Research Center, Thermal Storage Project Office.

1979 Thermal Energy Storage Program: Project Summaries, December 3-4, Tysons Corner, VA.

NASA Lewis Research Center, Thermal Storage Project Office. 72 pp.

1490 NASA Lewis Research Center.

1980 Thermal Energy Storage: Annual Report - January 1979 to March 1980. NASA Lewis Research Center, Cleveland. 69 pp. DOE/NASA/1034-8.

1979- Thermal Energy Storage Project: Management Report. NASA Lewis Research Center.

1098 Nakajima, Y.

1975 Design and Performance of Thermal Storage Water Tanks. Solar Use Now a Resource for People: International Solar Energy Society Conference.

1903 Nanda, P. and K.C. Hoffman.

1981 Assessment of portfolio analys is methods for R\&D program management. Technical and Economic Analysis Meeting, Chicago, April 22.

379 Naney, J.W., D.C. Kent and E.H. Seely.

1976 Evaluating ground-water paths using hydraulic conductivities. Ground Water 14(4):205-213.

382. Narasimhan, T., R. Schroeder, C.G. Goranson, D. McEdwards, D. Campbe 11, and J.H. Barkman.

1977 Recent Results From Tests on the Republic Geothermal Wells, East Mesa, California. Lawrence Berkeley Laboratory, Berkeley, CA. 10 pp. LBL-7017.

380 Narasimhan, T.N.

1978 The Significance of the Storage Parameter in Saturated-Unsaturated Groundwater Flow. Lawrence Berkeley Laboratory, Berkeley, CA. 33 pp. LBL-7041. (Preprint). 
381 Narasimhan, T.N.

1979 A Note on Volume Averaging.

Lawrence Berkeley Laboratory, Berkeley, CA. 13 pp. LBL-8792. (Preprint).

559

1969 Methods of analysis of pumping test data.

Ground Water 7(2):2-6.

1665

1980 Physical Aspects of the Interface between the Saturated and the Unsaturated Regimes.

Lawrence Berkeley Laboratory, Berkeley, CA. 2 pp. LBL-11178.

$1177 z$ Narasimhan, T.N., S. Juprasert and G.S. Bodvarsson.

1978 Mathematical simulation of thermal breakthrough under injection: comparison of two techniques.

pp. 77-78 in Earth Sciences Division Annual Report, Lawrence Berkeley Laboratory, Berkeley, CA. LBL-8648.

1177 am Narasimhan, T.N. and B.Y. Kanehiro.

1978 A Note on the meaning of storage coefficient. pp. 146-147 in Earth Sciences Division Annual Report, Lawrence Berkeley Laboratory, Berkeley, CA. LBL-8648.

$1177 \mathrm{ao}$

1978 Use of aquifer response to earth tides as a means of determining aquifer characteristics.

pp. 151-152 in Earth Sciences Division Annual Report, Lawrence Berkeley Laboratory, Berkeley, CA. LBL-8648.

383 Narasimhan, T.N. and P.A. Witherspoon.

1976 Numerical model for 1 and subsidence in shallow groundwater systems.

International Association of Hydrological Sciences, Proceedings of the Anaheim Symposium. 133-143.

1976 An Integrated finite difference method for analyzing fluid flow in porous media.

Water Resources Research 12(1):57-64.

1978 Numerical model for saturated-unsaturated flow in deformable porous media: 2 . the algorithm.

Water Resources Research 14(2):255-261.

1978 Numerical model for saturated-unsaturated flow in deformable porous media: 3. applications.

Water Resources Research 14(6):1017-1033. 
1177w Narasimhan, T.N. and W.A. Palen.

1978 Flow to a well intercepting a vertical fracture: validation of a numerical model.

Pages 72-74 in Earth Sciences Division Annual Report, Lawrence Berkeley Laboratory, Berkeley, CA. LBL-8648.

486 National Association of Corrosion Engineers, Technical Practices Committee.

1975 Selection of Metallic Materials to be Used in All Phases of Water Handling for Injection into 0il Bearing Formations. National Association of Corrosion Engineers, Houston. $10 \mathrm{pp}$. NACE Standard RP-04-75.

487 National Association of Corrosion Engineers, Technical Practices Committee.

1976 The Role of Bacteria in the Corrosion of 0il Field Equipment. National Association of Corrosion Engineers, Houston. 23 pp. NACE Pub. 3.

488 National Association of Corrosion Engineers, Technical Practices iommittee.

1977 Monitoring Techniques for the Control of Corrosion of Drill Pipe, Casing, and Other Components in Contact with Drilling Fluids.

National Association of Corrosion Engineers, Technical Practices Committee. 3 pp. NACE 1 D177.

489 National Association of Corrosion Engineers, Technical Unit Committee.

1954 Sulfide Corrosion Cracking of 011 Production Equipment. National Association of Corrosion Engineers, Houston. 413-417. NACE 1G 1154.

634 National Association of Corrosion Engineers and American Petroleum Institute.

1958 Corrosion of $0 i 1$ - and Gas-Well Equipment: Book 2 of the Vocational Training Series. American Petroleum Institute, Dallas. 87 pp.

1159 National Consumer Research Institute.

1977 Proceedings of the Energy Research and Development Administration Conference On: Cogeneration and Integrated Energy/Utility Systems. National Consumer Research Institute, Washington, DC. 97 pp. CONF-770632.

398 National Research Council, U.S. National Committee for Rock Mechanics, Energy Resource Recovery Dev.

1978 Limitations of Rock Mechanics in Energy-Resource Recovery and Deve lopment.

The National Academy of Sciences, Washington. $67 \mathrm{pp}$. 
1276 National Swedish Board for Technical Development.

1978- Energy Technology.

National Swedish Board for Technical Development, Stockholm, Sweden.

558 National Water Well Association.

1978 Shallowest Aquifer Water Level Elevations for the U.S.

National Water Well Association, Worthington, $\mathrm{OH}$.

(Pre-publication Release).

784

1976 Proceedings of the Third National Ground Water Quality Symposium, Las Vegas, Nevada, Sept. 15-17, 1976.

National Water We11 Association, Worthington, OH. PB-272 908.

892

1979 Comprehensive Ground Water Heat Pump Study: Progress Report.

National Water Well Association, Worthington, OH. 12 pp.

903

1980- We11 log: Newsletter of the National Water Well Association. National Water Well Association, Worthington, $\mathrm{OH} .11(1-)$.

1570

1979 Quick and dirty transactions of the NWWA Ground Water Technology Division program: October 10-11, OKlahoma City, OK.

Well Log: Newsletter of the National Water Well Association $10(11): 21-63$.

275 Nature.

1979 Getting steamed up over waste heat.

Nature 208:349.

1263 Nayfeh, A.H.

1972 Stability of liquid interfaces in porous media. The Physics of Fluids 15(10):1751-1754.

1146 Neal, J.W. and W.F. Savage (eds).

1979 Report of USA Delegation of U.S.-U.S.S.R. Coordinating Comm. on Scientific and Tech. Cooperation in the Field of Thermal Power Plant Heat Rejection Systems to the USSR. U.S. Department of Energy, Division of Fossil Fuel Utilization, Washington. DOE/ET-0076.

1177 as Nei1, J.M. and J.A. Apps.

1978 Solubility of albite in the aqueous phase at elevated temperatures.

Pages 160-164 in Earth Sciences Division Annual Report, Lawrence Berkeley Laboratory, Berkeley, CA. LBL-8648. 
1655 Nellor, M.H., F.D. Dryden and C. Chene.

1979 Health effects of groundwater recharge. Water Reuse Symposium, Washington, DC, March 25-30. 3:2146-2169.

926 Nelson, C.G.

1975 Program is designed to analyze casing buckling in thermal recovery.

$0 i 1$ and Gas Journal 73(49):79-82.

1499 Netherton, R. and L.B. Owen.

1978 Appartus for the Field Evaluation of Geothermal Effluent Injection.

Lawrence Livermore Laboratory, Livermore, CA. 5 pp. UCRL -81022.

387 Neuman, S.P. and T.N. Narasimhan.

1975 Mixed explicit-implicit iterative finite element scheme for diffusion-type problems: 1 . theory.

International Journal for Numerical Methods in Engineering $2: 309-323$.

1296 Newcomb, R.C.

1972 Quality of the Ground Water in Basalt of the Columbia River Group, Washington, Oregon, and Idaho.

U.S. Geological Survey, Arlington. 71 pp. Water-Supply Paper 1999-N.

388 Newman, M.E.

1977 Heat pump and water on the rocks.

Building Systems Design Oct-Nov:36-41.

555 Nicholls, R.L.

1977 Optimal proportioning of an insulated earth cylinder for storage of solar heat.

Solar Energy 19(9):711-714.

726

1978 Comparisons of deep well and insulated shallow earth storage of solar heat.

Solar Energy 20(2):127-137.

1099 Nicholson, E.W. and R.P. Cahn.

1976 Storage in $0 i 1$ of Off-Peak Thermal Energy from Large Power Stations.

11th Intersociety Energy Conversion Engineering Conference. $1: 598-605$. 
1100 Nielsen, C.E. and A. Rabl.

1975 Operation of a small salt gradient solar pond.

Solar Use Now a Resource for People: International Solar Energy Society Conference.

727 Nolen, J.S. and D.W. Berry.

1972 Tests of stability and time-step sensitivity of semi-implicit reservoir simulation techniques.

Society of Petroleum Engineers Journal 12(6):253-266.

1718 Nol1, S.

1980 How Can Energy-Efficient Structures Compete in an Inefficient Energy Market?

Los Alamos Scientific Laboratory, Los Alamos, NM. 11 pp. LA-UR $-80-848$.

839 Noran, D. (ed).

1977 Diversified equipment assists enhanced recovery.

$0 i 1$ and Gas Journal 75(43):75-80.

840

1978 Growth marks enhanced oil recovery. $0 i 1$ and Gas Journal 76(13):113-140.

1975 ERDA's enhanced-recovery program gathers momentum. $0 i 1$ and Gas Journal 73(44):77-81.

838

1976 Enhanced recovery requires special equipment. $0 i 1$ and Gas Journal 74(14):107-108.

841 Noyes, R. (ed).

1978 Cogeneration of Steam and Electric Power.

Noyes Data Corporation, Park Ridge, NJ. 259 pp.

1743 Nuclear Research Centre.

1979 Large Scale Thermal Storage Systems: Annex II, Interim Report 1979.

The Nuclear Research Centre, Julich, Germany.

14530 Nurmi, H.E.

1979 Panel discussion: DOE Program, phase I.

Official Proceedings, 70th Annual Conference of the International

District Heating Assn., June 18-20. Section 20.

1147 Nwude, J.K., H.L. Brown, B.B. Hamel, and A.J. Roman.

1975 Energy Conservation Systems Analys is: Food Processing Industry, Campbel1 Soup Company Plant No. 2.

Drexel University, Philadelphia, 31 pp. PB-281-718. 
842 O'Brien, L.J., R.S. Cooke, and H.R. Willis.

1978 Oil saturation measurements at Brown and East Voss Tannehil1 Fields. Journal of Petroleum Technology 30:17-25.

476 Oak Ridge National Laboratory.

1978 Minneapolis-St. Paul District Heating Study. Oak Ridge National Laboratory, Oak Ridge, TN. ORNL/SUB $-77 / 13502 / 4$. (Draft).

1236

1977 Project of a Heating and Ventilating System for Experimental-Industrial Large Greenhouses Heated with Thermal Power Plant.

Oak Ridge National Laboratory, Oak Ridge, TN. ORNL-TR-4485. (Microfiche).

1321

1979 Environmental Impact Assessment, Thermal Storage in Aquifers. Oak Ridge National Laboratory, Oak Ridge, TN. 104 pp. (Draft).

1518

1978- Low-Temperature Thermal Energy Storage: Monthly Progress Report. Oak Ridge National Laboratory, Oak Ridge, TN.

390 Obbink, J.G.

1969 Construction of piezometers, and method of installation for ground water observations in aquifers. Journal of Hydrology $7: 434-443$.

1795 Ochs, T., (ed).

1981 International Solar Pond Newsletter \#4. Los Alamos National Laboratory, Los Alamos, NM. 28 pp.

$1544 \mathrm{aq}$ offenhartz, P.0.

1980 A Chemical heat pump based on the reaction of calcium chloride and methanol for solar heating, cooling and storage. Proceedings of the DOE Thermal and Chemical Storage Annual Contractors' Review Meeting. 175-179.

1036 Offenhartz, P.0. and F.C. Brown.

1979 Methanol Based Heat Pumps for Storage of Solar Thermal Energy. American Chemical Society, Washington, DC. 507-509.

1866 Offenhartz, P.0., M.J. Turner, F.C. Brown, R.B. Warren, J.P. Pemsler and S.B. Brummer.

1979 Methanol-Based Heat Pumps for Storage of Solar Thermal Energy: Phase 1, Final Report.

EIC Corporation, Newton, MA. 109 pp. SAND-79-8188. (Microfiche). 
1199 Ogata, A.

1963 Effect of the injection scheme on the spread of tracers in ground-water reservoirs.

Paper 475-B, pp. 199-202 in U.S.G.S. Research, Short Papers in Geology and Hydrology, Articles 1-59, U.S.G.S.

1397 Ohtake, M.

1974 Seismic activity induced by water injection at Matsushiro, Japan. Journal Physical Earth 22:163-176.

$9280 \mathrm{il}$ and Gas Journal.

1976 Operators accelerate testing of micellar/surfactant potential. $0 i 1$ and Gas Journal 74(14):120-122.

944

1976 U.S. thermal recovery activity growing steadily.

$0 i 1$ and Gas Journal 74(14):108-119.

920

1978 Massive waterflood set for Reforma.

$0 i 1$ and Gas Journal 76(23):96-102

924

1976 Mining of viscous crude claimed viable.

$0 i 1$ and Gas Journal 74(1):46-47.

39301 iker, I.

1977 Heat Exchanger and Thermal Storage Problems in Power Stations Serving District Heating Networks.

American Society of Mechanical Engineers, New York. 8 pp. 77-HT-36.

1544 al

1980 Once-through heat supply system for City of Bellingham.

Proceedings of the DOE Thermal and Chemical Storage Annual

Contractors' Review Meeting. 156-158.

1729

1979 Heat Transport System for the Canadian Central Receiver Solar Utility.

Burns and Roe, Oradell, NJ. 48 pp.

$1454 \mathrm{C}$ 0liker, I. and A.M. Rubin.

1980 Piping networks for district heating applications. Official Proceedings, 71st Annual Conference of the International District Heating Assn, Harbor Springs, MI, June 23-25. Sec 9. 
84301 szewski, M.

1975 Agricultural Greenhouse Uses of Power Plant Reject Heat. Ph.D. Thesis, University of California, Berkeley. $96 \mathrm{pp}$. University Microfilms, Ann Arbor, MI. 76-15,328.

1229 01szewski, M., J.S. Suffern, C.C. Coutant and D.K. Cox.

1977 Overview of. Waste Heat Utilization Research at the Oak Ridge National Laboratory. Oak Ridge National Laboratory, Oak Ridge, TN. (Microfiche). CONF-770516-5.

394 0lszewski, M. and G.J. Trezek.

1976 Performance evaluation of an evaporative pad greenhouse system for utilization of power plant reject heat.

Journal of Environmental Quality 5(3):261-269.

1337 Onodera, T.

1957 Determination of Permeability by Pumping from a Spherical Well. IASH, pp. 212-218. Publication \#44.

1568 Ontario, Ministry of Education.

1980 International Conference on Thermal Storage in Buildings:

Toronto, November 12-14.

Ontario, Ministry of Education.

629 Oregon Institute of Technology, Geo-Heat Utilization Center.

1978 Klamath Falls, Orgeon. (Maps). Oregon Institute of Technology, Geo-Heat Utilization Center, Klamath Falls. 8 maps.

1344 Oregon Institute of Technology.

1977-Geo-Heat Utilization Center: Quarterly Bulletin.

1979

Oregon Institute of Technology, Klamath Falls, OR. 3(1), 4(1-3).

395 Oster, C.A. and W.A. Scheffler.

1976 We11-Hole Temperature Distribution in the Presence of Aquifers. Battelle, Pacific Northwest Laboratories, Richland, WA.

BNWL-SA-5658. (Draft).

728 0ster, C.A. and W.A. Scheffler.

1976 Well-Hole Temperature Distribution in the Presence of Aquifers. American Society of Mechanical Engineers, New York. 9 pp. 76-Pet-59.

$1544 \mathrm{ac}$ 0steryoung, R.A. and H. Fernandez.

1980 Corrosion behavior of alloys.

Proceedings of the DOE Thermal and Chemical Storage Annual

Contractors' Review Meeting. 110-111. 
1315w Owen, J.M. and E.W. Wilder.

1979 Underground liquid storage using isocyanurate foam at Ferrum College.

Proceedings of Solar Energy Storage Options, San Antonio, TX. March 19-20. 1:245-250. CONF-790328-P1.

1537 Owen, L.B., E. Raber, C. Otto, R. Netherton, R. Neurath and L. Allen.

1979 An Assessment of the Injectability of Conditioned Brine Produced by a Reaction Clarification: Gravity Filtration System in Operation at the Salton Sea Geothermal Field, CA. Lawrence Livermore Laboratory, Livermore, CA. 29 pp. UCID-18488.

396 Ozawa, T. and J. Fujii.

1970 A Phenomenon of scaling in production wells and the geothermal power plant in the Matsukawa Area.

U.N. Symposium on the Development and Utilization of Geothermal Resources, in Geothermics. 2(2):1613-1618.

1689 Paaswell, R.E.

1967 Thermal influence on flow from a compressible porous medium. Water Resources Research 3(1):271-278.

1457 Pacific Northwest Laboratory, Battelle.

1980 Multi-Year Plan: Seasonal Thermal Energy Storage Program. Pacific Northwest Laboratory, Battelle, Richland, WA. 32 pp.

1514

1980- Seasonal Thermal Energy Storage Program: Monthly Status Report. Pacific Northwest Laboratory, Batte1le, Richland, WA.

1482 ao Palmour, H., B.M. Gay and R.L. Cochrane.

1980 Domestic ceramic refractories for heat storage furnaces. Energy to the 21st Century: 15th Intersociety Energy Conversion Engineering Conference, Seattle, WA, August 18-22. 1:248-253.

729 Pandey, G.N., M.R. Tek, and D.L. Katz.

1973 Studies of Front-End Threshold Pressure Measurements. American Society of Mechanical Engineers, New York. 73-T-17 pp. T112-T116.

1200 Papadopulos, I.S.

1963 Preparation of type curves for calculating T/S of a wedge-shaped aquifer.

Paper 475-B, pp. 196-198 in U.S.G.S. Research, Short Papers in Geology and Hydrology, Articles 1-59, U.S.G.S.

399 Papadopulos, S.S. and S.P. Larson.

1978 Aquifer storage of heated water: Part 2. numerical simulation of field results.

Ground Water 16(4):242-248. 
1201 Parker, A.J., Jr., D.E. Cassel, R.E. Hedden, and T.N. Veziroglu.

1973 Application of Solar Cooling for a School Building in Subtropics. Mukler Associates, Inc., Baltimore and University of Miami, Coral Gables, Florida. $22 \mathrm{pp}$.

592 Parker, S.A.

1978 Power generation using thermal vapor pumping and hydro-pumped storage. Proceedings of Energy Technology Conference. 786-795.

1307 Parr, A.D., F.J. Molz, P.F. Andersen and J.C. Warman.

1979 Storage of thermal energy in confined aquifers: implications for solar energy.

Proceedings of the Solar Energy Storage Options, San Antonio, TX, March 19-20. 1:175-182.

1737 Parr, A.D., F.J. Molz and J.G. Melville.

1980 Field Studies of the Aquifer Thermal Energy Storage Concept. Auburn University, Department of Civil Engineering, Auburn, AL.

1383av Parr, A.D., F.J. Molz and P.F. Andersen.

1980 Hot-water aquifer storage: a field test. Thermal Energy Storage: Fourth Annual Review Meeting, Tysons Corner, VA, Dec. 3-4, 1979. 601-606. CONF-791232.

400 Pasquifer, $F$.

1977 Les conditions hydrogeologiques du stockage southerrain d'eau chaude en suisse.

Bullet in Du Centre D'Hydrogeologie (2):63-79.

1037 Patani, A. and U. Bonne.

1979 Modeling the Performance of Gas -Fired Heat Pump Systems. American Chemical Society, Washington, DC. 1699-1707.

844 Paul, J.K.

1977 Solar Heating and Cooling; Recent Advances.

Noyes Data Corporation. Park Ridge, NJ. 485 pp.

1303 Peart, R.M., and G.H. Foster.

1975 Grain Drying with Solar Energy. International Solar Energy Society Extended Abstracts, pp. $426-427$.

1202 Peaudecerf, P. and J.P. Sauty.

1978 Application of a mathematical model to the characterization of dispersion effects on groundwater quality.

Progressive Water Technology $10(5 / 6): 443-454$.

1660 Pelka, W.

1979 Two Well Storage Systems for Combined Heating and Air Conditioning by Groundwater Heat Pumps in Shallow Aquifers. Lawrence Berkeley Laboratory, Earth Sciences Division, Berkeley, 
CA. 74 pp. LBL-11302.

401 Penrod, E.B.

1954 Sizing earth heat pumps.

Refrigeration Engineering 62(4):57-61,108,112.

402 Perkins, T.K., G.R. Wooley, and F.W. Ng.

1975 Solutions for some problems resulting from refreezing of permafrost around a wellbore.

pp. 39-59 in Environmental Aspects of Chemical Use in

Well-Drilling Operations. U.S. EPA. EPA-560/1-75-004.

929 Perry, H.

1972 Conservation of Energy.

U.S. Senate, Comm. on Interior and Insular Affairs, A National

Fuels and Energy Policy Study. 114 pp.

1711 Perry, R.A. and C.J. Lewis.

1978 Definitions of Components of the Master Water Data Index

Maintained by the National Water Data Exchange.

U.S. Geological Survey, Reston, VA. 179 pp. Open-File Report 78-183.

403 Peters, R.R.

1975 Techniques of shallow well drilling.

pp. 27-38 in Environmental Aspects of Chemical Use in

We17-Dri11ing Operations, U.S. EPA. EPA-560/1-75-004.

1267 Peterson, F.L.

1979 Hawaiian Waste Injection Practices and Problems.

University of Hawaii, Water Resources Research Center, No. 21/Sept.

404 Peterson, J.S., C. Rohwer, and M.L. Albertson.

1953 Effects of well screens on flow into wells.

Transactions, American Society of Civil Engineers 120:563-607.

1544s Petri, R.J. and T.D. Claar.

1980 High-temperature molten salt thermal energy storage systems for solar applications.

Proceedings of the DOE Thermal and Chemical Storage Annual

Contractors' Review Meeting. 73-73d.

1845 Petri, R.J., T.D. Claar and L.G. Marianowski.

1979 Evaluation of Molten Carbonates as Latent Heat Thermal Energy Storage Materials.

American Chemical Society. 487-493. Paper no. 799100.

194 Petroleum Engineer.

1964 How to calculate heat transmission in hot fluid injection.

Petroleum Engineer 36(11):110-120. 
405 Pettitt, R.A.

1975 Planning, Drilling, and Logging of Geothermal Test Hole GT-2:

Phase I.

Los Alamos Scientific Laboratory, Los Alamos, NM. 42 pp. LA-5819-PR.

406

1975 Testing, Drilling, and Logging of Geothermal Test Hole GT-2:

Phase II.

Los Alamos Scientific Laboratory, Los Alamos, NM. 21 pp. LA-5897-PR.

407

1975 Testing, Drilling, and Logging of Geothermal Test Hole GT-2:

Phase III.

Los Alamos Scientific Laboratory, Los Alamos, NM. 13 pp.

LA-5965-PR.

408

1977 Planning, Drilling, Logging, and Testing of Energy Extraction Hole EE-1: Phases I and II.

Los Alamos Scientific Laboratory, Los Alamos, NM. LA-6906-MS.

409

1978 Testing, Planning, and Redrilling of Geothermal Test Hole GT-2: Phases IV and $V$.

Los Alamos Scientific Laboratory, Los Alamos, NM. LA-7586-PR.

1625

1980 Monitoring and Repairing Geothermal Casing Cement: A Case

History.

Los Alamos Scientific Laboratory. Los Alamos, NM. 4 pp.

LA-UR-80-1485.

410 Pettyjohn, W.A.

1979 Ground-water pollution: an imminent disaster.

Ground Water 17(4):18-23.

1600 Pezdirtz, G.E.

1979 Overview of Division of Energy Storage Program.

Sixth Energy Technology Conference, Washington, Feb 26-28. 896-901.

1592 Pfannkuch, H.O. and M.H. Edens.

1977 Rock properties for thermal energy storage systems in the 0 to 500 C range.

Proceedings of the Annual Meeting of the American Section of the International Solar Energy Society. 1:18-5 - 18-9.

1632 Pferdehirt, $W$. and N. Kron, Jr.

1980 District Heating From Electric Generating Plants and Municipal Incinerators: Local Planner's Assessment Guide.

Argonne National Laboratory, Argonne, IL. 125 pp. ANL/CNSV-12. (Preprint). 
411 Phillips, S.L., A.K. Mathur, and R.E. Doebler.

1976 A Survey of Treatment Methods for Geothermal Fluids. Society of Petreolem Engineers of AIME, Da11as. 187-196. SPE 6606 .

1038 Phillips, W.F. and R.A. Pate.

1974 A Hot Liquid Energy Storage System Utilizing Natural Circulation. American Society of Mechanical Engineers, New York. 74-WA/HT-16.

1039 Pierce, B.L., F.R. Spurrier, and M.K. Wright.

1977 Thermal energy storage.

12th Intersociety Energy Conversion Engineering Conference. $2: 1189-1194$.

1688 Pierce, R.L.

1970 Reducing land subsidence in the Wilmington $0 i 1$ Field by use of saline waters. Water Resources Research 6(5):1505-1514.

1203 Piety, R.G. and B.F. Wiley.

1952 Flowmeter for water injecting profiling. World $0 i 134(5): 176-186$.

1240 Pimental, K.D., D.H. Stuermer, and M.M. Moody.

1979 Sampling Strategies in Groundwater Transport and Fate Studies for In Situ $0 i 1$ Shale Retorting.

Lawrence Livermore Laboratory, Livermore, CA. 16 pp. UCRL-82417.

412 Pinder, G.F.

1973 A Galerkin-finite element simulation of groundwater contamination on Long Island, NY. Water Resources Research 9(6):1657-1669.

1659

1979 State of the Art Review of Geothermal Reservoir Modeling. Lawrence Berkeley Laboratory, Geothermal Subsidence Research Management Program, Berkeley, CA. 144 pp. LBL-9093 GSRMP-5.

1177 s Pines, H.S.

1978 Thermodynamic and cost benefits of floating cooling for geothermal binary-cycle power plants. pp. 60-65 in Earth Sciences Division Annual Report, Lawrence Berkeley Laboratory, Berkeley, CA. LBL-8648.

413 Piper, A.M.

1969 Disposal of Liquid Wastes by Injection Underground: Neither Myth nor Millennium.

U.S. Geological Survey, Arlington. $15 \mathrm{pp}$. Circular 631.

414 Pitt, W.A. Jr., F.W. Meyer, and J.E. Hu11.

1977 Disposal of salt water during well construction: problems and solutions. 
Ground Water 15(4):276-283.

1177 ar Pitzer, K.S., D.J. Bradley, P.Z. Rogers and J.C. Peiper.

1978 Thermodynamics of high-temperature brines.

pp. 158-159 in Earth Sciences Division Annual Report, Lawrence Berkeley Laboratory, Berkeley, CA. LBL-8648.

1880 Planning Research Corporation.

1978 Department of Energy's Solar Update: Four Regional Conferences. Planning Research Corporation, McLean, VA. 438 pp. CONF-780701. (Microfiche).

1243 Plantikow, U. and R. Jank.

1979 Large scale-energy storage in district heating systems. Dernforschunganlage Juelich, Juelich, F.R.G. 2 pp.

415 Plummer, K.H. and T.M. Rachford.

1974 Economic feasibility. pp. 9-42 in An Argo Power Waste Water Complex for Land Disposal of Waste Heat and Water, Pennsylvania State University.

591 Poland, J.F.

1969 Status of present knowledge and needs for additional research on compaction of aquifer systems. USA Proceedings Tokyo Symposium on Land Subsidence, IASH/AIHS Unesco. 11-21.

1960 Land subsidence in the San Joaquin Valley, CA., and its effect on estimates of ground water resources.

pp. 324-335 in Hydrogeology, International Association of Science Hydrogeology, Publication 52.

1976 Land subsidence stopped by artesian-head recovery, Santa Clara Valley, CA.

International Assoc. of Hydrological Sciences, Proceedings of the Anaheim Symposium. 124-132.

416 Poland, J.F. and G.H. Davis.

1956 Subsidence of the land surface in the Tulare-Wasco (Delano) and Los Banos-Kettleman City Area, San Joaquin Valley, California. Transactions, American Geophysical Union 37(3):287-296.

1969 Land subsidence due to withdrawal of fluids. pp. 187-269 in D.J. Varnes and G. Kirsch (eds), Reviews in Engineering Geology: Volume 2.

417 Poland, J.F. and J.H. Green.

1962 Subsidence in the Santa Clara Valley, California: A Progress Report. U.S. Geological Survey, Arlington. 17 pp. Water Supply Paper 1619-C. 
1360r Poling. B.E.

1979 Using reversible liquid phase reactions to store thermal energy. Proceedings of Solar Energy Storage 0ptions, San Antonio, TX, March 19-20. 1:515-522. CONF-790328-P2.

1674 Pollock, D.W.

1977 Numerical Simulation of Energy Transport in Shallow Aquifers Subjected to a Thermal Stress from High Temperature Energy Storage in the Unsaturated Zone.

M.S. Thesis, University of Minnesota, Minneapolis, MN. 149 pp.

1544ah Polzien, R.E.

1980 Thermal energy buffer storage for the small community solar thermal power experiment.

Proceedings of the DOE Thermal and Chemical Storage Annual Contractors' Review Meeting. 136-141.

1177u Pope, W.L.

1978 Heat-exchanger design optimization. pp. 57-59 in Earth Sciences Division Annual Report, Lawrence Berkeley Laboratory, Berkeley, CA. LBL-8648.

419 Pope, W.L., H.S. Pines, R.L. Fulton, and P.A. Doyle.

1978 Heat Exchanger Design: Why Guess a Design Fouling Factor When It Can Be Optimized?

Lawrence Berkeley Laboratory, Berkeley, CA. 33 pp. LBL-7067.

731 Potter, R.W.

1979 Reviews of Geophysics and Space Physics Computer Modeling in Low Temperature Geochemistry.

U.S. Geological Survey, Arlington. Paper \#9R0355. 17(4):850-860.

1205 Potter, R.W., D.R. Shaw, and J.L. Haas, Jr.

1975 Annotated Bibliography of Studies on the Density and Other Volumetric Properties for Major Components in Geothermal Waters $1928-74$.

U.S. Geological Survey, Arlington. 78 pp. Bulletin 1417.

1329 Powe11, J.D., and J.R. Powel1.

SEAS: A System for Undersea Storage of Thermal Energy.

Scripps Institute of Oceanography and Brookhaven National

Laboratory, Department of Nuclear Engineering.

583 Powel1, W.R.

1978 Community Annual Storage Energy System, CASES Simulation Model and Results.

Johns Hopkins University, Applied Physics Laboratory, Laurel, MD. 21 pp. NP-23511.

1978 The Case for CASES: a community annual energy storage system. Environmental 20(6):14-41. 
1268 Powel1, W.R.

1979 Simulation of the community annual storage energy system. pp. 25-51 in Ber 1 and Powell (eds), Efficient Comfort Conditioning: The Heating and Cooling of Buildings, Westview Press.

1760 Powell, W.R. and C.E. Williams.

1978 Cost Comparison of CASES with Air-Source Heat-Pump System. The Johns Hopkins University Applied Physics Laboratory, Laurel, MD. $51 \mathrm{pp}$.

1762

1978 Introduction to CASES and Evaluation Procedure.

The Johns Hopkins University Applied Physics Laboratory, Laurel, MD. $39 \mathrm{pp}$.

1761

1978 Parametric Analys is of CASES.

The Johns Hopkins University Applied Physics Laboratory, Laurel, MD. $115 \mathrm{pp}$.

1481 Prater, L.S.

1980 Aquifer Thermal Energy Storage Reference Manual.

Pacific Northwest Laboratory, Battelle, Richland, WA. PNL-3471.

1769 Prater, L.S., J.R. Eliason and V.E. Hampel.

1981 The Seasonal Thermal Energy Storage Technology Information System.

Pacific Northwest Laboratory, Battelle, Richland, WA. 11 pp.

PNL-SA-8800.

845 Prats, $M$.

1978 A Current appraisal of thermal recovery. Journal of Petroleum Technology 30:1129-1136.

1687

1969 The Heat efficiency of thermal recovery processes. Journal of Petroleum Technology Mar:323-332.

1811 Prenger, F.C. and R.D. Haberstroh.

1978 Heat Transfer in Packed Beds at Low Reynolds Number. The American Society of Mechanical Engineers, New York. 8 pp. $78-\mathrm{HT}-48$.

1531 President's Water Policy Implementation, Task Force 9.

1979 Water Conservation in Housing Assistance Programs: Final Report. U.S. Dept. of Agriculture, Farmers Home Administration, Veterans Administration, U.S. Dept. of Housing and Urban Dev. 27 pp. 
1275 Price, C.E.

1960 Artificial Recharge of a Well Tapping Basalt Aquifers, Walla Walla Area, WA. U.S. Geological Survey, Arlington. 50 pp. Water Supply Bulletin No. 7 .

441 Price, D., D.H. Hart, and B.L. Foxworthy.

1965 Artificial Recharge in Oregon and Washington: 1962. U.S. Geological Survey, Arlington. 65 pp. Maps. Water Supply Paper 1594-C.

1206 Price, D. and T. Arnow.

1974 Summary Appraisals of the Nation's Ground-Water Resources: Upper Colorado Region. U.S. Geological Survey, Arlington. 40 pp. Professional Paper 813-C.

442 Price, $M$.

1977 Specific yield determinations from a consolidated sandstone aquifer.

Journal of Hydrology 33:147-156.

1207 Pril1, R.C., A.I. Johnson, and D.A. Morris.

1965 Specific Yield: Laboratory Experiments Showing the Effect of Time on Column Drainage.

U.S. Geological Survey, Arlington. $55 \mathrm{pp}$. Water-Supply Paper $1662-B$.

1417 Prill, R.C. E.T. Oaksford and J.E. Potorti.

1979 A Facility Designed to Monitor the Unsaturated Zone during Infiltration of Tertiary-Treated Sewage, Long Island, New York. U.S. Geological Survey, Arlington. Water-Resources Investigations 79-48. $14 \mathrm{pp}$.

443 Pruess, K., G. Bodvarsson, R. Schroeder, P. Witherspoon, R. Marconcini, G. Neri, and C. Ruffilli.

1979 Simulation of the Depletion of Two-Phase Geothermal Reservoirs. Lawrence Berkeley Laboratory, Berkeley, CA. 16 pp. LBL-9606.

440 Pruess, K., J.M. Zerzan, R.C. Schroeder and P.A. Witherspoon.

1979 Description of the Three-Dimensional Two-Phase Simulator SHAFT78 for Use in Geothermal Reservoir Studies. Society of Petroleum Engineers of AIME, Dallas. pp. 253-261. SPE -7699 .

1177 ac Pruess, K., R.C. Schroeder, P.A. Witherspoon and J.M. Zerzan.

1978 Development of the simulator SHAFT78 for geothermal reservoir studies.

Pages 94-96 in Earth Sciences Division Annual Report, Lawrence Berkeley Laboratory, Berkeley, CA. LBL-8648. 
1227 Public Service Electric Gas Co.

1976 Assessment of Energy Storage Systems Suitable for Use by Electric Utilities, Final Report.

Public Service Electric and Gas Co., Newark, NJ. Vol. 1, 2, and 3. (Microfiche) EPRI-EM-264.

1666 Public Utilities Fortnightly.

1981 Getting into "hot water" is project goal.

Public Utilities Fortnightly Jan15:59-60.

197 Public Works.

1977 Hydraulics and economics of well field layout. Public Works 108(1):40-41.

1041 Quade, R.N.

1974 The High temperature gas-cooled reactor as a source of high temperature process heat.

Nuclear Engineering and Design 26:179-186.

1498 Quong, R., F. Shoepflin and N.D. Stout.

1978 Conditioning of Geothermal Brine Effluents for Injection: Use of Coagulants.

Lawrence Livermore Laboratory, Livermore, CA. 17 pp. UCID-17716.

1475 Quong, R., K.G. Knauss, N.D. Stout and L.B. Owen.

1979 An Effective $\mathrm{H}_{2} \mathrm{~S}$ Abatement Process Using Geothermal Brine Effluents.

Lawrence Livermore Laboratory, Livermore, CA. 3p. UCRL -83010.

420 Qvale, E.B.

The Danish Seasonal Aquifer Warm Water Storage Program.

Technical University of Denmark, Laboratory for Energetics. 2 pp.

421

1976 Seasonal storage of thermal energy in water in the underground. 11 th Intersociety Energy Conversion Engineering Conference Proceedings. 1:628-635.

$1526 \mathrm{RPC}$, Inc.

1979 An Analysis of Ecological Effects of Geopressured-Geothermal Resource Development.

RPC, Inc., Austin, TX. Vol. 4. Geopressured-Geothermal Technical Paper No. 4. DOE/ET/28464-1.

1979 Legal Issues Related to Geopressured-Geothermal Resource Development.

RPC, Inc., Austin, TX. Geopressured-Geothermal Technical Paper No. 1. DOE/ET/28464-1. 
733 Raats, P.A.C.

1975 Transformations of fluxes and forces describing the simultaneous transport of water and heat in unsaturated porous media. Water Resources Research 2(6):938-942.

422 Rabbimov, R.T., G.Y. Umarov and R.A. Zakhidov.

1971 Storage of solar energy in a sandy-gravel ground. Geliotekhnika 7(5):57-64.

423

1974 Experimental study of aquifer heating in solar-energy accumulation. Gel iotekhnika 10(2):20-27.

424 Rabbimov, R.T., R.A. Zhakhidov and G.Y. Umarov.

1974 Temperature distribution in accumulation of solar energy in an aquifer. Geliotekhnika 10(2):15-19.

1847 Radebold, R.D. New Generation MHD-Systems Based on Alkali Metals for the Storage of Solar Energy on Hydrazine and Hydrogen-Peroxide. Arbeitsgeme inschaft Exergietransformer. 23-38.

1437 Radosevich, L.G.

1980 Thermal Energy Storage for Solar Thermal Applications Program Progress Report: October 1979-March 1980.

Sandia National Laboratories, Thermal Subsystems Division, Livermore, CA. $107 \mathrm{pp}$.

1415 Rae, J. and P.C. Robinson.

1979 NAMMU: Finite Element Program for Coupled Heat and Groundwater Flow Problems. AERE Harwe11, Theoretical Physics Division, Oxfordshire, England. $22 \mathrm{pp}$.

1846 Raetz, J.E., C.R. Easton and R.J. Holl.

1975 The Selection and use of energy storage for solar thermal electric application. Tenth Intersociety Energy Conversion Engineering Conference, Newark, DE, August 18-22. 576-582.

425 Rahman, M.A., E.T. Smerdon, and E.A. Hiler.

1969 Effect of sediment concentration on well recharge in a fine sand aquifer. Water Resources Research 5(3):641-646.

846 Raimondi, P., B.J. Gallagher, R. Ehrlich, J.H. Messmer, and G.S. Bennett.

1977 Alkaline waterflooding: design and implementation of a field pilot.

Journal of Petroleum Technology 29:1359-1368. 
1396 Raleigh, C.B., J.H. Healy, and J.D. Bredehoeft.

1976 An Experiment in earthquake control at Rangely, Colorado. Science 191:1230-1237.

1042 Ramakumar, R. and J.C. Beaver.

1979 Perspectives on Developing Country Solar Energy Applications. American Chemical Society, Washington, DC. 93-98.

1383e Ramanathan, V., T.E. Weast and K.P. Ananth.

1980 Thermal energy storage systems using fluidized bed heat exchangers.

Therma1 Energy Storage: Fourth Annual Review Meeting, Tysons Corner, VA, Dec. 3-4. 47-56. CONF-791232.

1283 Rambo, J.T. and B.L. Coles.

1978 User's Manual for the Livermore Economic Modeling System. Lawrence Livermore Laboratory, Livermore, CA. 92 pp. UCRL -52526.

426 Ramey, H.J., Jr.

1975 Pressure transient analysis for geothermal wells. Proceedings, Second U.N. Symposium on the Development and Use of Geotherma1 Resources. 3:1749-1757.

627

1962 Wellbore heat transmission. Journal of Petroleum Technology 14:427-435.

1975 Interference analysis for anisotropic formations: a case history. Journal of Petroleum Technology 27:1290-1298.

1959 Transient heat conduction during radial movement of a cylindrical heat source: applications to the thermal recovery process.

Petroleum Transactions, AIME 216:115-122.

847 Ramey, H.J., Jr., A. Kumar, and M.S. Gulati.

1973 Gas Wel1 Test Analysis Under Water-Drive Conditions. American Gas Association, Arlington. 312 pp.

931 Rande11, J.E.

1977 Long term heat storage. Building Service Engineer 45(9):163-169.

848 Ranney, M.W.

1979 Crude $0 i 1$ Drilling Fluids. Noyes Data Corporation, Park Ridge, NJ. 348 pp.

1101 Rao, S.K. and R.K. Suri.

1969 Thermal characteristics of homogeneous packed beds with steady fluid flow. 
The Journal of the Institution of Engineers (India) 50:63-70.

974 Ratigan, J.L.

1976 Analysis of the Potential for Thermally-Induced Rock Fracture Around Emplaced Heat Storage.

RE/Spec Inc., Rapid City, SD. 27 pp. (Preprint).

1569 Raymond, J.R.

1980 Geohydrologic Aspects of Aquifer Thermal Energy Storage.

Pacific Northwest Laboratory, Battelle, Richland, WA. 21 pp. PNL-SA-8834.

1102 Read, W.R. and J. Czech.

1975 Operating Experience with a Solar Timber Kiln. Solar Use Now a Resource for People: International Solar Energy Society Conference.

1383au Redde11, D.L., R.R. Davison and W.B. Harris.

1980 Cold water aquifer storage.

Thermal Energy Storage: Fourth Annual Review Meeting, Tysons Corner, VA, Dec. 3-4, 1979. 591-600. CONF-791232.

1752 Reed, D.B. and D.L. Redde 11.

1980 Heat Transport in Groundwater Systems: Volume 2, Laboratory Mode 1 .

Texas A\&M University, Texas Water Resources Institute. 158 pp. TR-104.

1775 Reed, J.E.

1980 Type Curves for Selected Problems of Flow to Wells in Confined Aquifers.

U.S. Geological Survey. Techniques of Water Resources

Investigations. TWI-3-B3.

428 Reed, M.G.

1977 Formation permeability damage by mica alteration and carbonate dissolution. Journal of Petroleum Technology 28:1056-1060.

1043 Reed, R.D.

1976 Recover energy from furnace stacks. Hydrocarbon Processing 55(1):127-128.

1209 Reeder, H.0.

1978 Summary Appraisals of the Nation's Ground Resources: Souris-Red-Rainy Region.

U.S. Geological Survey, Arlington. $25 \mathrm{pp}$. Professional Paper $813-K$.

1975 Injection-pipe system for artificial recharge.

Journal of Research, U.S. Geological Survey 3(4):501-503. 
1536 Reeder, H.0., W.W. Wood, G.G. Ehrliech and R.J. Sun.

1976 Artificial Recharge Through a Well in Fissured Carbonate Rock, West St. Paul, MN.

U.S. Geological Survey, Arlington. 80 pp. Supply Paper 2004.

1433 Reffstrup, J.

1979 Prediction of Recovery Ratios and Flow Conditions in Connection with Seasonal Thermal Energy Storage in Confined Aquifers. Technical University of Denmark, Laboratory for Energetics, Lyngby, Denmark. $85 \mathrm{pp}$. RE79-15.

1434

1979 Prediction of Recovery Ratios and Flow Conditions in Connection with Seasonal Thermal Energy Storage in Confined Aquifers:

Appendices $A, B$, and $C$.

Technical University of Denmark, Laboratory for Energetics, Lyngby, Denmark. 227 pp.

$1544 n$ Reid, R.L. and A.F.G. Bedinger.

1980 Performance of stratified thermal storage system for 01 iver Springs Elementary School: progress report.

Proceedings of the DOE Thermal and Chemical Storage Annual Contractors' Review Meeting. 52-54.

1445 Reilly, R.W.

1980 A Descriptive Analysis of Aquifer Thermal Energy Storage Systems. Pacific Northwest Laboratory, Battelle, Richland, WA. 71 pp. PNL-3298.

1582h Reilly, R.W., D.R. Brown and H.D. Huber.

1980 Economic assessment of aquifer thermal energy storage. Mechanical, Magnetic, and Underground Energy Storage 1980 Annual Contractors' Review. pp. 38-41. CoNF-801128.

1768

1980 The Economics of aquifer storage of chilled water for air conditioning.

15th Intersociety Energy Conversion Engineering Conference, Seatt le, August 18-22. 1265-1271. Paper 809250.

1044 Reimels, R. and J.E. Howe 11. Solar energy for process heat.

Brown and Root, Inc. and University of Houston, Department of Mechanical Engineering. pp. 58-76.

785 Reistad, G.M., W.E. Schmisseur, J.R. Shay, and J.B. Fitch. (eds).

1978 An Evaluation of Uses for Low to Intermediate Temperature Geothermal Fluids in the Klamath Basin, OR. Oregon State University. Corvallis. $130 \mathrm{pp}$. 
9999dr Republic Geothermal, Inc.

1980 Geothermal Reservoir Well Stimulation Program: Technology Transfer.

Republic Geothermal, Inc., Sante Fe Springs. 140 pp. Vol. 4. $\mathrm{DOE} / \mathrm{AL} / 10563-\mathrm{T} 3$.

1596 Riaz, M.

1978 Long term storage of solar energy in native rock.

International Solar Energy Society-UK Section; Sun: Mankind's

Future Source of Energy Conference. 1:474-479.

1809

1977 Analytical solutions for single- and two-phase models for packed-bed thermal storage systems.

Journal of Heat Transfer 99 (Aug):489-492.

849 Riaz, M., P.L. Blackshear, and H.0. Pfannkuch.

1976 High-temperature energy storage in native rocks.

International Solar Energy Society, American Section. 8:127-137.

$1383 q$ Rice, R.E. and P.E. Rowny.

1980 Development of a thermal storage module using modified anhydrous sodium hydroxide.

Thermal Energy Storage: Fourth Annual Review Meeting, Tysons Corner, VA, Dec. 3-4. 173-182. CONF-791232.

1045 Richards, W.D. and W.S. Chiu.

1979 System Performance of a Stirling Engine Powered Heat Activated Heat Pump.

American Chemical Society, Washington, DC. 1693-1698.

895 Ridgeway, J. and C.S. Projansky.

1979 Energy-Efficient Community Planning: A Guide to Saving Energy and Producing Power at the Local Level. JG Press. Emmaus, PA. 221 pp.

429 Ridgeway, S.L., and J.L. Dooley.

1976 Underground storage of off-peak power.

11th Intersociety Energy Conversion Engineering Conference Proceedings. 1:586-590.

1338 Rima, D.R., E.B. Chase and B.M. Myers.

1971 Subsurface Waste Disposal by Means of Wells: A Selected Annotated Bibliography. U.S. Geological Survey, Arlington. 305 pp. Water-Supply Paper 2020.

1046 Ritland, P.D. and B. Coffay.

1979 An Open Cycle Approach to Ocean Thermal Energy Conversion. American Chemical Society, Washington, DC. 195-202. 
1896 Ritter, A.B. and G.B. Delancey.

1978 Thermochemical Energy Conversion and Storage: Final Report. Stevens Institute of Technology, Hoboken, NJ. 24 pp. DOE/ET/26956-T1.

1544d Rizzuto, J.E.

1980 Design and demonstration of a storage-assisted air conditioning system. Proceedings of the DOE Thermal and Chemical Storage Annual Contractors' Review Meeting. 12-15.

1630 Roach, F.

1980 Groundwater: Alternatives and Solutions. Los Alamos Scientific Laboratory. Los Alamos, NM. 43 pp. LA-UR $-80-1516$.

430 Roache, P.J. and T.S. Mueller.

1970 Numerical solutions of laminar separated flows. AIAA Journal 8(3):530-538.

1754 Roback, J.J.

1980 Timely technical topics: aquifer thermal energy storage. District Heating 65(4):42-43.

431 Robeck, G.G.

1969 Microbial problems in ground water. Ground Water 7(3):33-35.

770 Robert S. Kerr Environmental Research Laboratory and National Water Well Association.

1974 Proceedings of the Second National Ground Water Quality Symposium, Sept. 25-27, Denver, CO. U.S. Environmental Protection Agency, Technology Transfer, Washington. $251 \mathrm{pp}$.

932 Robertson, D.C. and C.H. Kelm.

1975 Injection-we11 testing to optimize waterflood performance. Journal of Petroleum Technology 27:1337-1342.

1151 Robertson, S.J. and P.0. McCormick.

1977 Solar Industrial Process Heat for Kiln Drying Lumber: Final Report, Phase 1. Huntsville Research and Engineering Center. Huntsville, AL. 62 pp. OR0-5042-2.

432 Robichaux, J.

1975 Bactericides used in drilling and completion operations. pp. 183-198 in Environmental Aspects of Chemical Use in We11-Drilling Operations, U.S. EPA. EPA-560/1-75-004. 
1152 Rocket Research Company.

1979 Industrial Electrical Cogeneration Potential in the Bonneville Power Administration Service Area.

Rocket Research Co., Redmond, WA. RRC-79-R-615.

1290

1978 Heat Pump Centered Integrated Community Energy Systems: System Development, Rocket Research Company Interim Report. Argonne National Laboratory, Argonne, IL. 421 pp. ANL/ICES-TM-27.

1384

1980 Interim Institutional Consideration Report for Application of Thermal Energy Storage to Process Heat and Waste Heat Recovery. Rocket Research Company, Redmond, WA. RRC 79-R644, Rev A.

1675

1980 Industrial Waste Heat for Community Applications: Phase IIIDemonstration of Heat Recovery and District Heating in Bellingham, Washington.

Rocket Research Company, Redmond, WA. 80-P-919.

590 Rodriquez-Amaya, C.

1976 A Decomposed Aquifer Model Suitable for Management.

Ph.D. Thesis, Colorado State University, Fort Collins. NTIS PB-265 091.

1133 Rogan, J.E., D.A. Carey, S.M. Hatasaka, D. Quan and R.E. Snyder.

1977 Industrial Applications of Solar Total Energy: Final Report. McDonne 11 Douglas Astronautics Co., Huntington Beach, CA. Vol 4. $133 \mathrm{pp}$. SAN/1132-2/4.

735 Rogers, F.C. and W.E. Larson.

1974 Underground energy storage.

Proceedings, American Power Conference 36th Annual Meeting, Chicago, IL. 36:369-378.

433 Romagnoli, P., G. Cuellar, M. Jimenez, and G. Ghezzi.

1975 Aspectos hidrogeologicos del campo geotermico de ahuachapan, El Salvador.

Proceedings, Second United Nations Symposium on the Development and Use of Geothermal Resources. 1:563-570.

434 Romero, J.C.

1970 The Movement of bacteria and viruses through porous media. Ground Water 8(2):37-48.

850 Rose, K.S.

1978 Gelled acid coaxes oil from tight Permian carbonates. World $0 i 1187: 115-116$. 
589 Roseen, R.

1978 Central Solar Heat Station in Studsvik. Studsvik Report. $15 \mathrm{pp}$. STUDSVIK/ET-78/77.

1485 Roseen, R. and B. Perers.

1980 A Solar Heating Plant in Studsvik: Design and First Year Operational Performance.

Swedish Couricil for Building Research, Stockholm, Sweden. 100 pp. D 21:1980.

1902 Rosenzweig, S. and A.B. Cambel.

1981 Energy storage bibliography.

Technical and Economic Analysis Meeting, Chicago, April 22.

586 Ross, P.N.

1975 Process heat: the temperature amplifier-a kind of industrial heat pump.

Electric Apparatus 28(3):29-31.

1286 Rousseau, W.F., J.T. Rambo, R.N. Castleton and S.S. Sussman.

1978 Computer Code Documentation for the Livermore Economic Modeling System.

Lawrence Livermore Laboratory, Livermore, CA. 26 pp. UCRL -52519.

1284 Rousseau, W.F., S.S. Sussman, R.N. Castleton and J.T. Rambo.

1978 Economic Models and Algorithms Used in the Livermore Economic Modeling System.

Lawrence Livermore Laboratory, Livermore, CA. 135 pp. UCRL-52527.

1777 Rouve, G. and H. Lutkestratkotter.

1979 Injection of cooling water into groundwater. Proceedings of the 3rd World Congress on Water Resources, Mexico. International Water Resources Assocation. 2688-2699.

435 Rozenfeld, L.M. and G.S. Serdakov.

1968 Increasing the efficiency of a heat supply system based on geothermal water by using heat pumps.

Thermal Engineering 15(8):75-81.

436 Rubin, $\mathrm{H}$.

1977 Thermal convection in a cavernous aquifer. Water Resources Research 13(1):34-40.

1771 Rubin, $H$. and C. Roth.

1978 On the growth of instabilities in groundwater due to temperature and salinity gradients. Advances in Water Resources 2(2):69-76.

437 Rubinshtein, L.I.

1959 The Total heat losses in injection of a hot liquid into a stratum.

Neft $i$ Gaz 2(9):41-48. 
1582 ad Rudd, N.

1980 Field studies of porous rock reservoirs. Mechanical, Magnetic, and Underground Energy Storage 1980 Annual Contractors' Review. pp. 227-232, CONF-801123.

439 Rushton, K.R. and L.M. Toml inson.

1976 Permissible mesh spacing in aquifer problems solved by finite differences. Journal of Hydrology $34: 63-76$.

438 Rushton, K.R. and Y.K. Chan.

1977 Numerical pumping test analysis in unconfined aquifers. Journal of the Irrigation and Drainage Division, ASCE 103( IR1) :1-12.

1048 Saari, R.

1978 Desalination by very low-temperature nuclear heat. Nuclear Technology 38:209-214.

444 Saffman, P.G.

1959 A Theory of dispersion in a porous medium. Journal of Fluid Mechanics 6:321-349.

1598 Sagar, B. and S.R. Singh.

1979 Aquifer diffusivity from noisy boundary data. Journal of the Hydraulics Division 105(HY8):943-954.

1594 Saha, H.

1978 Heat transfer characteristics of water filled cans as solar thermal storage medium: a comparative test data analysis. Proceedings of the Annual Meeting of the American Section of the International Solar Energy Society. 2:664-670.

1049 Sakhuja, R. and G. Mileris.

1979 Heat Pump System for Process Steam Generation. American Chemical Society, Washington, DC. 1708-1712.

587 Saleem, Z.A. and C.E. Jacob.

1973 Drawdown distribution due to well fields in coupled leaky aquifers: 1 . infinite aquifer systems. Water Resources Research 9(6):1671-1678.

1453d Saleta, V.A., R.P. Ulfstam and R.H. Tourin.

1979 Retrofitting steam-electric plants to supply heat for district heating.

Official Proceedings, 70th Annual Conference of the International District Heating Assn. June 18-20. Section 9.

445 Salieva, R.B. and R.P. Saliev.

1975 Principles of technological-economic calculations in solar technology. Geliotekhnika 11(5):44-51. 
776 Salk, M.S. and S.G. DeCicco (eds).

1978 Environmental Monitoring Handbook for Coal Conversion Facilities. Oak Ridge National Laboratory, Oak Ridge, TN. ORNL-5319.

446 Saltzman, B. and J.A. Pollack.

1977 Sensitivity of the diurnal surface temperature range to changes in physical parameters. Journal of Applied Meteorology 16:614-619.

1383 ag Salyer, I.0.

1980 Development of optimum process for electron beam cross-linking of high density polyethylene thermal energy storage pellets. Thermal Energy Storage: Fourth Annual Review Meeting, Tysons Corner, VA, Dec. 3-4, 1979. 315-328. CONF-791232.

$1544 f$ Salyer, I.0. and J.E. Davidson.

1980 Development of an optimum process for electron beam crosslinking of high density polyethylene pellets.

Proceedings of the DOE Thermal and Chemical Storage Annual Contractors' Review Meeting. 20-23.

108 Sandia Livermore Laboratory.

1978 Energy Technology: 3rd Annual Proceedings of Thermal Energy Storage Contractors' Information Exchange Meeting - December 5-6, 1978, Springfield, VA.

U.S. Department of Energy, Division of Energy Storage Systems, Washington, D.C. 465 pp. CONF-781231.

1515 Sandia National Laboratories.

1980- Solar Thermal Applications: Thermal Energy Storage Status Letter. Sandia National Laboratories, Livermore, CA.

736 Santing, G.

1951 A Horizontal scale model based on the viscous flow analogy for studying ground water flow in an aquifer having storage. pp. 105-115 in Hydrogeology, International Association of Science, Toronto.

1631 Santini, D.J. and E.P. Levine.

1980 Indirect Benefits of Cogeneration District Heating. Argonne National Laboratory, Argonne, IL. 18 pp.

1643 Santini, D.J. and S.S. Bernow.

1979 Feasibility of district heating and cooling of core areas of major northern U.S. cities by cogeneration from central station power plants. Northeast Regional Science Association Meetings, Amherst, MA, May 18-20. $25 \mathrm{pp}$.

1103 Santoleri, J.J.

Energy Recovery from Low Heating Value Industrial Waste. Trane Thermal Company, Conshohocken, PA. pp. 124-131. 
738 Sanyal, S.K., S.S. Marsden, and H.J. Ramey.

1974 Effect of Temperature on Petrophysical Properties of Reservoir Rocks .

Society of Petroleum Engineers of AIME, Dallas. SPE-4898.

737 Sanyal, S.K. and H.T. Meidav.

1977 Important Considerations in Geothermal We11 Log Analysis. Society of Petroleum Engineers of AIME, Dallas. 6 pp. SPE-6535.

1249 Sapsford, C.M.

1974 The Use of solar energy in process industries. National Chemical Engineering Conference Process Industries in Australia: Impact and Growth. 331-340.

1104 Sarkar, S., B.N. Mittal, S.C.L. Tewari.

1973 Utilization of waste heat in flue gases. Journal of the Institution of Engineers (India) 54:31-35.

588 Sarot, J.

1979 Heat Storage Thermal Study of Large Diameter Drilled and Especially Turbodrilled-Storage Tanks.

Polytechnique DeMons. $11 \mathrm{pp}$. Report E/X/2.1/79/1.

1495 Sasman, R.T.

1972 Thermal pollution of ground water by artificial recharge. Water Sewage Works 119(12):52-55.

739 Sather, N.F., L.G. Lewis, G.T. Kartsounes, and H.H. Chiu.

1976 Compressed Air Energy Storage Systems Studies: Progress Report for FY 1976.

Argonne National Laboratory, Energy and Enviromental Systems

Division, Argonne, IL. 73 pp. TID-28797.

1105 Saulnier, B., N. Chepurniy, S.B. Savage, and T.A. Lawand.

1975 Field Testing a Solar Pond. Solar Use Now a Resource for People: International Solar Energy Society Conference.

1656 Sauty, J.P., A.C. Gringarten, A. Menjoz and P.A. Landel.

1980 Sensible Energy Storage in Aquifers: 1-Theoretical Study. Bureau de Recherches Geologiques et Minieres, Orleans, France.

1210 Sauty, J.P., A.C. Gringarten, and P.A. Landel.

1978 The effect of thermal dispersion on injection of hot water in aquifers.

Second Invitational We11-Testing Symposium Proceedings. CONF-7810170. 122-131.

1360 ac Scaringe, R.P.

1979 A Variable capacity thermal storage device. Proceedings of Solar Energy Storage Options, San Antonio, TX, March 19-20. 1:609-618. CONF-790328-P2. 
1780 Schaetzle, W.J., C.E. Brett, D.M. Grubbs and M.S. Seppanen.

1980 Thermal Energy Storage in Aquifers: Design and Application. Pergamon Press, New York. 177 pp.

9999ed Schaetzle, W.J., C.E. Brett and D.M. Grubbs.

1979 Energy Storage in Groundwater Aquifers.

Sun 2: Proceedings of the International Solar Energy Society

Silver Jubilee Congress, Atlanta, GA, May 1979. 1:614-618.

852 Schaetzle, W.J., C.E. Brett and D.M. Grubbs.

1980 A Heat pump community-integrated energy system using annual aquifer energy storage.

ASHRAE Winter Annual Meeting, February 3-7, Los Angeles.

853

1979 Annual Thermal Energy Storage in Ground-Water Aquifers. Trinity University, Solar Energy Storage Options. 10 pp.

854

1979 Community integrated cooling and heating system.

International Conference on Energy: Use Management, Los Angeles, Oct 22-26. 8 pp.

855

1979 Direct Cooling Utilizing Aquifer Thermal Energy Storage. Argonne National Laboratory, Argonne, IL. 27 pp.

856

1979 Annual energy storage in aquifers for community energy systems. International Energy Symposia, Montreus, Switzerland, June 19-22. $6 \mathrm{pp}$.

857

1979 Energy storage in ground-water aquifers.

ISES Silver Jubilee Congress 1979. Atlanta, GA, May 28-June 1. 6 $\mathrm{pp}$.

851 Schaetzle, W.J., C.E. Brett and J.M. Ansari.

Thermal Energy Storage in Aquifers for a Solar Power Plant. University of Alabama, University, AL, and University of Petroleum and Minerals, Dhahran, Saudi Arabia. 3 pp.

1308 Schaetzle, W.J., C.E. Brett and M.S. Seppanen.

1979 Heat-Pump-Centered Integrated Community Energy Systems: System Development, Univ. of Alabama, Final Report.

Argonne National Laboratory, Argonne, IL. 267 pp. ANL/CNSV-TM-25.

859 Schaetzle, W.J., J.E. LeCroy, M.S. Seppanen and C.E. Brett.

1979 Waste Heat Utilization with Annual Aquifer Storage.

Argonne National Laboratory, Argonne, IL. 2 pp. 
858 Schaetzle, W.J., L.R. Fang, C.E. Brett and D.M. Grubbs.

1979 A solar energy system with annual aquifer storage. ASME Solar Energy Division, ASME Winter Annual Meeting. New York, Dec. 2-7. $16 \mathrm{pp}$.

1318 Schaetzle, W.J., and C.E. Brett.

1978 Heat Pump Centered Integrated Community Energy Systems: System Development, Interim Report.

University of Alabama, Bureau of Engineering Research and Natural Resources Center. 162 pp.

882 Schaetzle, W.J. and C.E. Brett.

1979 Heat Pump Centered Integrated Community Energy Systems: System Development, University of Alabama Interim Report.

University of Alabama, Natural Resources Center, University, AL. 163 pp. ANL/ICES-TM-30.

447 Schafer, D.C.

1974 The Right chemicals are able to restore or increase well yield. Johnson Drillers Journal 46(2):4-6.

1551 Schatz, J.F., P.W. Kasameyer, J.A. Cheney.

1979 Method of Using In Situ Porosity Measurements to Place an Upper Bound on Geothermal Reservoir Compaction.

Lawrence Livermore Laboratory, Livermore, CA. 5 pp. UCRL-81506.

1759 Schertz, W.W.

1980 Long-Term Ice Storage for Cooling Application.

U.S. Department of Energy, Washington. 12 pp. PAT-APPL-603-7078.

1332 Schiff, L.

1957 The Use of filters to maintain high infiltration rates in aquifers for ground water recharge.

IASH, pp. 207-211. Publication no. 44.

448 Schiff, L. and K.L. Dyer.

1965 Some physical and chemical considerations in artificial ground water recharge.

Biennial Conference on Groundwater Recharge, Development and Management. $\mathrm{H}-60-71$.

1575 Schipper, L.

1979 International Analysis of Residental Energy Use and Conservation. Lawrence Berkeley Laboratory, Berkeley. 28 pp. LBL-9383.

1106 Schmidt, E.W. and P.A. Lowe.

1976 Thermochemical energy storage systems. 11th Intersociety Energy Conversion Engineering Conference. $1: 665-702$. 
449 Schmidt, K.D.

1977 Water quality variations for pumping wells. Ground Water 15(2):130-137.

740 Schneider, F.N. and W.W. Owens.

1976 Relative permeability studies of gas-water flow following solvent injection in carbonate rocks.

Society of Petroleum Engineers Journal 16(2):23-30.

244 Schneider, R.

1962 Correlation of Ground-Water Levels and Air Temperatures in the Winter and Spring in Minnesota. U.S. Geological Survey, Arlington. $14 \mathrm{pp}$. Water-Supply Paper 1539-D.

732

1962 An Application of Thermometry to the Study of Ground Water. U.S. Geological Survey, Arlington. 16 pp. Water-Supply Paper $1544-B$.

963

1962 Use of thermometry in hydrogeologic studies of glacial deposits at Worthington, Minnesota.

Geological Society of America Bulletin 73:1305-1308.

1591

1972 Distortion of the Geothermal Field in Aquifers by Pumping. U.S. Geological Survey, Arlington. Professional Paper 800-C. C267-C270.

1315aa Schnurr, N.M. and J.W. Williamson.

1979 Preliminary evaluation of a combined heat pump/thermal storage system for residential use. Proceedings of Solar Energy Storage Options, San Antonio, TX. March 19-20. 1:271-280. CONF-790328-P1.

1472 Schoe11, G.

1980 Artificial lake as energy store. VDI Nachrichten No. 13. 3 pp.

1544k Schoenhals, R.J., C.P. Lin, H.F. Kuehlert and S.H. Anderson.

1980 Thermal energy storage testing facility.

Proceedings of the DOE Thermal and Chemical Storage Annual

Contractors' Review Meeting. 39-42.

1383v Schoenhals, R.J., H.F. Kuehiert and C.P. Lin.

1980 Thermal energy storage testing facility.

Thermal Energy Storage: Fourth Annual Review Meeting, Tysons

Corner, VA, Dec. 3-4, 1979. 223-232. CONF-791232. 
450 Schreiber, D.L., A.E. Reisenauer, K.L. Kipp, and R.T. Jaske.

1973 Anticipated Effects of an Unlined Brackish-Water Canal on a Confined Multiple-Aquifer System.

Battelle, Pacific Northwest Laboratories, Richland, WA. 37 pp. BNWL-1800.

879 Schrock, V.E. and A.D.K. Laird.

1976 Physical modeling of combined forced and natural convection in wet geothermal formations.

Journal of Heat Transfer $98(C-2): 213-220$.

585 Schroder, J.

1975 Thermal energy storage and control.

Transactions of ASME, Journal of Engineering for Industry $97: 893-896$.

1848

1974 Thermal Energy Storage and Control.

The American Society of Mechanical Engineers. 4 pp. 74-WA/0cT-1.

938 Schulte and Koerting Company.

1964 Steam Jet Exhausters and Compressors.

Schulte and Koerting Company. 7 pp.

860 Schumacher, M.M. (ed).

1978 Enhanced 011 Recovery: Secondary and Tertiary Methods.

Noyes Data Corporation, Park Ridge, NJ. 207 pp.

760 Scientific Softwater Corporation.

1975 Reservoir Engineering Manual.

Scientific Softwater Corporation, Denver. PB 247806.

$1383 n$ Scott, O.L.

1980 Internally insulated thermal storage system development program. Thermal Energy Storage: Fourth Annual Review Meeting, Tysons Corner, VA, Dec. 3-4. 141-156. CONF-791232.

451 Scott, R.W.

1972 Two new drilling systems pass initial field tests. Wor ld 0 il $174(1): 35-43$.

1409 Scott Periodicals Corp.

1980 The Solar pond comes of age.

Ground Water Age 14(7):25.

1507

1980 - Ground Water Age.

Scott Periodicals Corp., Elmhurst, IL. 14(6-12).

1301 Segaser, C.S.

1978 Survey of Solar Thermal Energy Storage Subsystems for Thermal/Electric Aplications. 
Oak Ridge National Laboratory, Oak Ridge, TN. 86 pp. ORNL/TM-5758.

1720 Segaser, C.S. and J.E. Christian.

1979 Low Temperature Thermal-Energy Storage. Oak Ridge National Laboratory, Oak Ridge, TN. 56 pp. ANL/CES/TE-79-3.

452 Segerstrom, S.

1971 Heat pumps today. Journal of ASHRAE 13(7):63-65.

1776 Segesman, F.F.

1980 Well-logging method. Geophysics $45(1): 1667-1684$.

880 Sepaskhah, A.R., L. Boersma, L.R. Davis and D.L. Slegel.

1973 Experimental analysis of a subsurface soil warming and irrigation system utilizing waste heat. Winter Annual Meeting of American Society of Mechanical Engineers. 12 pp. 73-WA/HT-11.

741 Serata, S.

1974 Borehole-Stress Property Measuring System. U.S. Patent No. 3,796,091.

U.S. Patent Office, Washington, DC.

1051 Sevcik, V.J.

1976 Thermal Energy Storage and Transportation. Proceedings of the American Section of the International Solar Energy Society and the Solar Energy Society of Canada, Inc.

742 Shaffer, L.H.

1977 Solar ponds: low cost solar energy management systems. Energy 2(3):18-20.

$1193 f$ Shamsundar, N. and R. Srinivasan.

1978 Analysis of energy storage by phase change with an array of cylindrical tubes.

pp. 25-40 in Thermal Storage and Heat Transfer in Solar Energy Systems, American Society of Mechanical Engineers, New York.

1405 . Shannon, R.J.

1975 Geothermal heating of government buildings in Rotorua. Proceedings of the Second U.N. Symposium on the Development and Use of Geothermal Resources, San Francisco, May 20-29. 2165-2172.

1212 Shapiro, L.

1975 Rapid Analysis of Silicate, Carbonate, and Phosphate Rocks: Revised Edition. U.S. Geological Survey, Arlington. 76 pp. Bulletin 1401. 
933 Sharp, M.K. and R. I. Loehrke.

1979 Stratified thermal storage in residential solar energy applications. Journal of Energy 3(2):106-113.

$1482 u$ Shaw, D., A.P. Bruckner and A. Hertzberg.

1980 A New method of efficient heat transfer and storage at very high temperatures.

Energy to the 21st Century: 15th Intersociety Energy Conversion Engineering Conference, Seattle, WA, August 18-22. 1:125-132.

453 Sheahan, N.T.

1977 Injection/extraction well system: a unique seawater intrusion barrier.

Ground Water 15(1):32-50.

861 Sheely, C.Q.

1978 Description of field tests to determine residual oil saturation by single-well tracer method.

Journal of Petroleum Technology 30:194-202.

1877 Sheft, I., D.M. Gruen, G.J. Lamich.

1979 HYCSOS Chemical Heat Pump and Energy Conversion System Based on Metal Hydrides.

Argonne National Laboratory, Argonne, IL. 8 pp. CONF-790446-5. (Microfiche).

1535 She inbaum, I.

1976 Power production from high salinity geothermal waters. Geothermal Energy 4(3):7-9.

1422 Shelton, J.

1975 Underground storage of heat in solar heating systems. Solar Energy 17(2):137-143.

454 Shew, D.C. and J.W. Keeley.

1975 Ground-water problems associated with well-drilling additives. pp. 223-230 in Environmental Aspects of Chemical Use in Wel1-Drilling Operations, U.S. EPA. EPA-560/1-75-004.

934 Shippee, D.

1978 The Sun earth house.

Proceedings Annual Meeting of the Am Sect of the Int' 1 Solar Energy Society Inc.: Solar Diversification, Denver, Aug 28-31.

$1315 f$ Short, T.H., W.L. Roller and H.M. Keener.

1979 Agricultural applications of solar storage systems. Proceedings of Solar Energy Storage Options, San Antonio, TX. March 19-20. 1:51-66. CONF-790328-P1.

743 Siege 1, R.

1974 Conformal mapping technique for two-dimensional porous media and jet impingement heat transfer. 
Heat Transfer 1974, Proceedings of Fifth International Heat Transfer Conference, Tokyo, Sept 3-7. 1:205-209.

1383ae Sigmon, T.W.

1980 Simulation and evaluation of 1 atent heat thermal energy storage heat pump systems.

Thermal Energy Storage: Fourth Annual Review Meeting, Tysons Corner, VA, Dec. 3-4, 1979. 297-306. CONF-791232.

1904

1981 Dispersed energy storage analysis.

Technical and Economic Analysis Meeting, Chicago, Apri1 22.

1544c Sigmon, T.W., J.H. Davidson, J.M. Doster, J.F. Martin, J.A.

Edwards.

1980 Simulation and evaluation of latent heat thermal energy storage heat pump systems.

Proceedings of the DOE Thermal and Chemical Storage Annual

Contractors' Review Meeting. 7-10.

584 Signhal, A.K., D.P. Mikherjec, and W.H. Somerton.

1976 Effect of heterogeneous wettability on flow of fluids through porous media.

Journal of Canadian Petroleum Technology 15(3):20-31.

1274 Signor, D.C., D.J. Growitz and W. Kam.

1970 Annotated Bibliography on Artificial Recharge of Ground Water, 1955-1967.

U.S. Geological Survey, Arlington. 141 pp. Water-Supply Paper 1990.

$1177 q$ Silvester, L.F.

1978 Thermodynamic and transport properties of light hydrocarbons and their binary mixtures.

pp. 52-54 in Earth Sciences Division Annual Report, Lawrence

Berkeley Laboratory, Berkeley, CA. LBL-8648.

1177ai Simkin, T.L., J.E. Noble and W.J. Schwarz.

1978 Geothermal subsidence research program.

pp. 128-129 in Earth Sciences Division Annual Report, Lawrence

Berkeley Laboratory, Berkeley, CA. LBL-8648.

455 Simpson, J.P.

1975 Drilling fluid principles and operations.

pp. 61-71 in Environmental Aspects of Chemical Use in

Wel1-Drilling Operations, U.S. EPA. EPA-560/1-75-004.

1628 Sinclair, A.R., F.J. Pittard and R.J. Hanold.

1980 Geothermal Well Stimulation.

Los Alamos Scientific Laboratory, Los Alamos, NM. 5 pp.

LA-UR-80-1825. 
744 Singh, B.S. and A. Dybbs.

1974 Heat transfer characteristics of porous media.

Proceedings of Fifth International Heat Transfer Conference. $5: 98-102$.

745 Singh, M.M. and P.J. Huck.

1971 Effect of Specimen Size on Rock Properties.

Society of Petroleum Engineers of AIME, Dallas. 12 pp. SPE-3528.

1824 Singh, V., R.A. Bajura and S.H. Schwartz.

1979 Influence of Pumped Storage Flows on Thermal Stratification in Reservoirs.

West Virginia University, Department of Mechanical Engineering and Mechanics, Morgantown, WV. 155 pp. Rpt. no. 10, PB 297131.

1213 Sinnott, A. and E.M. Cushing.

1978 Summary Appraisals of the Nation's Ground-Water Resources: Mid-Atlantic Region.

U.S. Geological Survey, Arlington. $32 \mathrm{pp}$. Professional Paper $813-$ I.

1295 Sitzer, S., R. Moden and P. Don Victor.

1979 Historical and Forecasted Energy Prices by DOE Region and Fuel Type for Three Macroeconomic Scenarios. Energy Information Administration. AR/EU79-39. DOE/EIA-0184/15.

9999df Skougstad, M.W., M.F. Fishman, L.C. Friedman, D.E. Erdmann and S.S. Duncan.

1979 Methods for Determination of Inorganic Substances in Water and Fluvial Sediments.

U.S. Geological Survey, Arlington. Techniques of Water Resources Investigations, Book 5, Chapter A1.

1052 Sliwinski, B.J., A.R. Mech and T.S. Shih. Stratification in Thermal Storage During Charging. U.S. Army CERL, Champaign, IL, and University of I11 inois, Urbana. EU-6. pp. 149-154.

746 Sloat, B.

Injection Water Treatment Starts in the Producing Wells. Society of Petroleum Engineers of AIME, Dallas. 6 pp. SPE-875.

1606 Smith, A.J.

1980 Design is the key to a good recharge wel1. Johnson Drillers Journal 52(2):8-10.

1881 Smith, C.C.

1978 Third Annual Conference on Solar Energy for Heating of Greenhouses.

Colorado State University, Fort Collins. 127 pp. CONF-7804110. (Microfiche). 
456 Smith, C.G., Jr. and J.S. Hanor.

1977 Underground storage of treated water: a field test. Ground water 13(5):410-417.

457 Smith, C.R. and S.J. Pirson.

1963 Water coning control in oil wells by fluid injection. Society of Petroleum Engineers Journal 3:314-326.

1107 Smith, G.A. and A.M. Severson.

1975 Salt Thermal Energy Storage for Solar Systems. Solar Use Now a Resource for People: International Solar Energy Society Conference.

458 Smith, G.C., J.A. Stottlemyre, L.E. Wiles, W.V. Loscutoff, and H.J. Pincus.

1978 FY-1977 Progress Report: Stability and Design Criteria Studies for Compressed Air Energy Storage Reservoirs.

Pacific Northwest Laboratory, Battelle, Richland, WA. PNL-2443.

459 Smith, G.S.

1951 Climatology as an aid in heat pump design.

Heating, Piping and Air Conditioning 23(6):101-107.

460 Smith, J.E.

1975 Regulation of onshore and offshore oilfield waste disposal. pp. 579-591 in Environmental Aspects of Chemical Use in Wel1-Drilling Operations, U.S. EPA. EPA-560/1-75-004.

1586 Smith, L. and R.A. Freeze.

1979 Stochastic analys is of steady state groundwater flow in a bounded domain: 2. two-dimensional simulations. Water Resources Research 15(6):1543-1559.

1482 an Smith, R.D.

1980 Chemical energy storage for solar thermal electric conversion. Energy to the 21st Century: 15th Intersociety Energy Conversion Engineering Conference, Seattle, WA, August 18-22. 1:243-247.

935 Smith, R.S.

1976 Injection-pump study can cut costs.

$0 i 1$ and Gas Journal 74(8):99-102.

461 Sneddon, I.N.

1946 The Distribution of stress in the neighborhood of a crack in an elastic solid.

Proceedings, Royal Society, Series A. 187:229-260.

1503 Snoeberger, D.F. and J.H. Hi11.

1978 Identification of Environmental Control Technologies for Geothermal Development in the Imperial Valley of California. Lawrence Livermore Laboratory, Livermore, CA. 30 pp. UCRL-52548. 
462 Snyder, R.E.

1978 Geothermal Well Completions. Sandia Laboratories, Livermore, CA. 121 pp. SAND 78-7010.

936

1975 Practical ideas to improve field production operations. World 0 il 181:74-78.

1487 Solar Energy Research Institute.

1979 Thermal Energy Storage for Solar Applications: An Overview. Solar Energy Research Institute, Golden, CO. (Microfiche).

1517

1979- Solar Energy Storage Program: Monthly Status Report. Solar Energy Research Institute, Golden, CO.

1785

1980 Systems Simulation and Economic Analysis Conference Proceedings: San Diego, CA, January 23-24.

Solar Energy Research Institute, Golden, C0. 488 pp. SERI/TP-351-431.

1663 Solar Times.

1980 Underground bodies of water are studied as possible heat storage tanks. Solar Times 2(10):5.

554 Solomon, A.D.

1979 Mathematical Modeling of Phase Change Processes for Latent Heat Thermal Energy Storage.

Oak Ridge National Laboratory, Oak Ridge, TN. 131 pp. ORNL/CSD-39.

747

1979 On Modeling for Moving Boundary Problems.

Union Carbide Corp., Nuclear Division, Oak Ridge, TN. 20 pp. CONF 79034-1.

1980 Mathematical modeling of moving boundary problems in thermal energy storage. Proceedings of the DOE Thermal and Chemical Storage Annual Contractors' Review Meeting. 33-35.

1193k Somerton, C.W. and I. Catton.

1978 Convective instability of a volumetrically heated porous bed. pp. 71-79 in Thermal Storage and Heat Transfer in Solar Energy Systems, American Society of Mechanical Engineers, New York.

1177 aq Somerton, W.H., A. Ghaffari, R. Greenwald, V. Hoang, F.

Martinez-Baez, H.J. Su and L. Wong.

1978 Behavior of rock-fluid systems at elevated pressures and temperatures. 
Pages 154-157 in Earth Sciences Division Annual Report, Lawrence Berkeley Laboratory, Berkeley, CA. LBL-8648.

463 Somerton, W.H., and S. ET-Hadidi.

1971 Weil logs can indicate formation drillability. World 0 il $173(7): 55-56$.

1408 Somerton, W.H. and.A.K. Mathur.

1976 Effects of temperature and stress on fluid flow and storage capacity of porous rock.

17th Symposium on Rock Mechanics, Session 2A. 2A2-1 - 2A2-8.

464 Sorey, M.L.

1978 Numerical Modeling of Liquid Geothermal Systems.

U.S. Geological Survey, Arlington. 25 pp. Professional Paper 1044-D.

1360t Sowe11, E.F.

1979 Control for residential load management using rock-bed, heat pump and solar collectors.

Proceedings of Solar Energy Storage Options, San Antonio, TX, March 19-20. 1:531-538. CONF-790328-P2.

937 Sparlin, D.D.

1976 An Evaluation of polyacrylamides for reducing water production. Journal of Petroleum Technology 28:906-914.

465 Specken, G.A.

1975 Treatment and disposal of waste fluids from onshore driliing sites. pp. 451-462 in Environmental Aspects of Chemical Use in We11-Drilling Operations, U.S. EPA. EPA-560/1-75-004.

1360u Spencer, D.L.

1979 Performance of a multiple-trough heat storage system. Proceedings of Solar Energy Storage Options, San Antonio, TX, March 19-20. 1:539-546. DOE-CONF-790328-P2.

1739 Spencer, J.F.

1980 Legal, Institutional and Regulatory Considerations for Aquifer Thermal Energy Storage. National Conference on Renewable Energy Technologies.

466. Spencer, R.S., W.S. Butler, M.K. Enns and B.W. Wilkinson.

1976 The Potential for fuel economics via combined steam power production.

11th Intersociety Energy Conversion Engineering Conference Proceedings. 1:565-572.

$1578 \mathrm{fq}$ Spencer, S.G.

1979 Injection at Raft River: an environmental concern? Geothermal Resources Council Transactions 3:675-678. 
1778 Spencer, S.G. and D.M. Callan.

1980 Analysis of the Response of the Raft River Monitor Wells to the 1979 Injection Test.

EG\&G Idaho, Inc., Idaho Falls. 27 pp. EGG-2057.

1053 Sperry, R.E., S. Toney, and D.J. Shade.

1976 Some Adverse Effects of Stress Corrosion in Steam Turbines. American Society of Mechanical Engineers, New York. $6 \mathrm{pp}$.

$76-I P C-P w r-8$.

467 Spillette, A.G.

1965 Heat transfer during hot fluid injection into an oil reservoir. pp. 21-26 in Thermal Recovery Techniques, Society of Petroleum Engineers of AIME, Dallas.

468 Spofford, W.A.

1959 Heat pump performance for package air sources units. Journal of ASHRAE 1(4):59-63.

1897 Spogen, L.R., V.E. Hampel and J.R. Raymond.

1981 Technology information system review. Technical and Economic Analysis Meeting, Chicago, April 22. UCRL-85863. (Draft).

862 Spotila, J.R.

1978 Thermoregulation of Fish and Turtles in Thermally Stressed Habitats.

State University College at Buffalo, Department of Biology, NY. $27 \mathrm{pp} . \mathrm{CO0}-2502-15$.

863 Stalkup, F.I.

1978 Carbon dioxide miscible flooding: past, present, and outlook for the future. Journal of Petroleum Technology 30:1102-1112.

469 Stallman, R.W.

1956 Numerical analysis of regional water levels to define aquifer hydrology.

Transactions, American Geophysical Union 37(4):451-460.

1214

1962 Orientation of axes for calculating distribution of transmissibility from water-level altitudes.

Paper 450-E, pp. 165-166 in U.S.G.S. Research, Short Papers in Geology, Hydrology, and Topography, Articles 180-239, U.S.G.S.

1544ar Standley, W.R., R. Gorman, P.S. Moritz and T.J. O'Gorman.

1980 A Cost-effectiveness evaluation of chemical heat pumps. Proceedings of the DOE Thermal and Chemical Storage Annual Contractors' Review Meeting. 181-184. 
470 Stark, M., N. Goldstein, H. Wollenberg, B. Strisower, H. Hege, and M. Wilt.

1979 Geothermal Exploration Assessment and Interpretation, Klamath Basin, Oregon - Swan Lake and Klamath Hills Area. Lawrence Berkeley Laboratory, Berkeley, CA. 75 pp. LBL -8186 .

1812 Staton, B.G.

1978 Solar heating of commercial greenhouses. Proceedings, Solar Industrial Process Heat Conference, October 18-20. 125-131. SERI/TP-49-065.

1814

1977 Solar Heating of an Ohio Commercial Greenhouse. Lockheed Missiles and Space Co., Inc., Huntsville Research and Engineering Center, Huntsville, AL. 5 pp.

864 Stecher, P.G. (ed).

1979 Industrial and Institutional Waste Heat Recovery. Noyes Data Corporation, Park Ridge, NJ. 362 pp.

1054 Steele, B.L.

1975 Selection of Plant Cooling Source(s). American Society of Mechanical Engineers, New York. 75-IPWR-6.

1751 Stefan, H. and C.V. Nguyen.

1976 Waste Heat Dissipation and Effluent Water Temperatures From Black Dog Lake. University of Minnesota, St. Anthony Falls Hydraulic Laboratory. Project Report No. 162.

1108 Stepler, R.

1978 Revolving barrel banks solar heat. Popular Science May:91.

1582c Stern, L.I.

1980 Conceptual Design of Aquifer Thermal Energy Storage System Demonstration, State Univ. of N.Y. Stony Brook Campus, Long Is Iand. Mechanica1, Magnetic, and Underground Energy Storage 1980 Annual Contractors' Review. pp. 28-33. CONF-801128.

582 Stickford, G.H., Jr., C.F. Holt, and G.R. Whitacre. 1976 Analysis of buried heat storage tank losses. International Solar Energy Society, American Section, 10:173-175. (Abstract).

471 Stilwel1, W.B., W.K. Ha11, and J. Tawhai.

1975 Ground movement in New Zealand geothermal fields. Proceedings of the Second U.N. Symposium on the Development and Use of Geothermal Resources. 1427-1433.

1383aw Stottlemyre, J.A.

1980 Equilibrium geochemical modeling of a seasonal thermal energy storage aquifer field test. 
Thermal Energy Storage: Fourth Annual Review Meeting, Tysons Corner, VA, Dec. 3-4, 1979. 607-620. CONF-791232.

1582ae Stottlemyre, J.A.

1980 Investigating air/water/rock interactions in a CAES porous rock reservoir.

Mechanical, Magnetic, and Underground Energy Storage 1980 Annual Contractors' Review. pp. 220-226. CONF-801128.

$1582 \mathrm{~m}$ Stottlemyre, J.A., C.H. Cooley and G.J. Banik.

1980 Physiochemical properties analyses in support of the Seasonal Thermal Energy Storage Program.

Mechanical, Magnetic, and Underground Energy Storage 1980 Annual Contractors' Review. pp. 89-95. CONF-801128.

553 Stottlemyre, J.A., R.A. Craig, W.V. Loscutoff, D.W. Boehm, and G.C. Chang.

1978 Environmental concerns related to compressed air energy storage. Compressed Air Energy Storage Symposium Proceedings. $6 \mathrm{pp}$. PNL -SA-7112.

1685 Stottlemyre, J.A., R.L. Erikson and R.P. Smith.

1979 Permeability and Friability Alterations in Quartzose Sandstones Exposed to Elevated Temperature Humidified Air.

Pacific Northwest Laboratory, Battelle, Richland, WA. 8 pp.

472 Stottlemyre, J.A., R.P. Smith, and R.L. Erikson.

1979 Potential Physical and Chemical Property Alterations in a Compressed Air Energy Storage Porous Rock Reservoir.

Pacific Northwest Laboratory, Battelle, Richland, WA. 23 pp. PNL-2974.

1979 Geochemical Equilibrium Modeling of the Auburn Thermal Energy Storage Field Test.

Pacific Northwest Laboratory, Battelle, Richland, WA. PNL-3167.

473 Stracke, K.J., D.C. Mason, and R.G. Altman.

1969 Cyclic steam-injection operations: Guadalupe Field, California. pp. 35-39 in Drilling Production and Practice, American Petroleum Institute.

865 Strange, L.K. and A.W. Talash.

1977 Analysis of Salem low-tension waterflood test. Journal of Petroleum Technology 29:1380-1384.

474 Straus, J.M. and G. Schubert.

1977 Thermal convection of water in a porous medium: effects of temperature- and pressure-dependent thermodynamic and transport properties. Journal of Geophysical Research 82(2):325-333. 
748 Strausberg, S.I.

1957 Estimating distances to hydrologic boundaries from discharging wel1 data.

Ground Water 5(1):5-8.

1626 Strawn, J.A.

1980 Results of acid treatments in hydrothermal direct heat experiment wells.

Geothermal Resource Council Annual Meeting. 4 pp. CONF-800920-16.

581 Streltsova, T.D.

1976 Unsaturated zone and vertical - flow components in draining unconfined formations. Journal of Hydrology $31: 119-124$.

475 Streltsova, T.D. and K.R. Rushton.

1973 Water table drawdown due to a pumped well in an unconfined aquifer. Water Resources Research 9(1):236-242.

1849 Stunic, Z., V. Djurickovic and Z. Stunic.

1978 Thermal Storage: Nucleation of Melts of Inorganic Salt Hydrates. Journal of Applied Chemical Biotechnology 28:761-764.

1109 Styris, D.L., R.J. Zaworski, O.K. Harling, and J. Leshuk.

1975 Nonconvecting Solar Pond, Some Applications and Stability Problem Areas.

Solar Use Now a Resource for People: International Solar Energy Society Conference.

477 Subcasky, W.J.

1978 Petroleum industry experience in water injection.

Proceedings of Thermal Energy Storage in Aquifer Workshop. $3 \mathrm{pp}$. LBL CONF-7805140.

867 Sudol, G.A., R.F. Harrison, and H.J. Ramey, Jr.

1979 Annotated Research Bibliography for Geothermal Reservoir Engineering.

Lawrence Berkeley Laboratory, Earth Sciences Division. Berkeley, CA. $150 \mathrm{pp}$. LBL-8664.

1262. Sugawara, A. and Y. Yoshizawa.

1962 An Expermental investigation on the thermal conductivity of consolidated porous materials. Journal of Applied Physics 33(10):469-480.

478 Sugisaki, R.

1961 Measurement of effective flow velocity of ground water by means of dissolved gases.

American Journal of Science 259:144-153. 
1055 Sullivan, D.

1979 Technology Impact Study of a High Efficiency Industrial Heat

Pump.

American Chemical Society, Washington, DC. 1725-1729.

579 Sulzberger, V.T. and J. Zemkoski.

1976 Potential for application of energy storage capacity on electrical utility systems in the United States - Part I. IEEE Transactions on Power Apparatus and Systems Pas-95(6):1872-1881.

580

1977 Potential for application of energy storage capacity on electrical utility systems in the United States - Part II. IEEE Transactions on Power Apparatus and System Pas $-96(1): 213-221$.

479 Suman, G.0. and R.C. Ellis.

1977 Cementing $0 i 1$ and gas wells: Part 2. Wor ld 0 i 1 184(5):69-76.

480

1977 Cementing $0 i 1$ and gas wells: Part 3. World 0 il $184(6): 48-57$.

481

1977 Cementing $0 i 1$ and gas wells: Part 4. World 0 i1 $184(7): 69-77$.

1977 Cementing oil and gas wel1s: Part 5. World 0 i1 $184(8): 117-125$.

483 Sumner, J.A.

1955 Central heating by heat pump: report of three years operation in a bungalow. Engineering 179:439-441.

484

1955 Domestic heating by the heat pump. Journal of the Institution of Heating and Ventilating Engineers $23: 129-151$.

1395 Sun, R.J.

1977 Possibility of triggering earthquakes by injection of radioactive wastes in shale at Oak Ridge National Laboratory, TN. Journal of Research, U.S. Geological Survey 5(2):253-262.

1453n Sundberg, R.E., R. Leas and J.0. Kolb.

1979 Twin Cities institutional issues study: cogenerated hot water district heating. Official Proceedings, 70th Annual Conference of the International 
District Heating Assn. June 18-20. Section 19.

578 Surface, M.0.

1977 Exotic power and energy storage.

Power Engineering 81(12):36-44.

1285 Sussman, S.S. and W.F. Rousseau.

1978 A New Language for Economic General Equilibrium Models. Lawrence Livermore Laboratory, Livermore, CA. 13 pp. UCRL-52507.

1392 Swanberg, C.A.

1977 Physical Aspects of Pollution Related to Geothermal Energy Development.

University of New Mexico, Las Cruces. 9 pp.

1593 Swanson, S.R., G.M. Sandquist, J.K. Kunze.

1977 Forced Convective Heat Transfer in Porous Media with Small Biot Number.

American Society of Mechanical Engineers, New York. 5 pp. 77-HT-96.

485 Swartzendruber, 0.

1962 Non-Darcy flow behavior in liquid-saturated porous media. Journal of Geophysical Research 67(13):5205-5213.

1788 Swet, C.J. and F. Baylin.

1980 Central Unresolved Issues in Thermal Energy Storage for Building Heating and Cooling.

Solar Energy Research Institute, Golden, C0. 40 pp. SERI/RR-721-455.

868 Swet, C.J. and W.J. Masica.

1977 Thermal storage for electric utilities. Conference: New Options Energy Technology. AIAA/EET/IEEE. 26-32.

1519 Sydansk, R.D.

1980 Discussion of the effect of temperature and confining pressure on single-phase flow in consolidated rocks. Journal of Petroleum Technology 32:1329-1330.

1746 Syska, A.J. and A. Brzezinski.

1980 Heat Recovery Devices: New.

Thermal Systems Engineering, Inc. Woburn, MA. 50 pp. GRI-78/0041.

1645 Szabo, B.S.

1980 Thermal tank efficiency. Heating, Piping, Air Conditioning 52(3):63-71.

1056 Szego, J. and F.W. Schmidt.

1978 Transient behavior of solid sensible heat thermal energy storage units.

Journal of Heat Transfer 100(1):148-154. 
925 TRANE Air Company.

1948 The Nation's largest heat pump installation.

TRANE Air Company 12(2):1-8.

550 TRW, Energy System Planning Division.

1979 Thermal Energy Storage Application Areas.

TRW, Energy System Planning Division, McLean, VA.

1216 Takasaki, K.J.

1978 Summary Appraisals of the Nation's Ground-Water Resources:

Hawai i Region.

U.S. Geological Survey, Arlington. 29 pp. Professional Paper $813-M$.

1853 Talaat, M.E.

1976 A Pressurized Liquid Concept for Solar-Thermal Energy Storage for the 24-Hour Continuous Operation of an Energy Conversion System.

The American Society of Mechanical Engineers, New York. 8 pp. $76-\mathrm{WA} / \mathrm{HT}-38$.

577 Talmage, S.S. and C.C. Coutant.

1978 Thermal effects.

Journal of Water Pollution Control Federation 50:1514-1529.

1315ab Talwar, R.

1979 A Model and its experimental validation of phase-change energy storage in two-dimensional cylindrical coordinates.

Proceedings of Solar Energy Storage Options, San Antonio, TX.

March 19-20. 1:281-292. CONF-790328-P1.

1440 Tam, S.W., C.A. Blomquist and G.T. Kartsounes.

1978 Underground Pumped Hydo Storage: An Overview.

Argonne National Laboratory, Argonne, IL. 11 pp.

1858 Tanaka, T., K. Sakuta, M. Kamimoto, T. Tani, S. Sawata and T.

Horigome.

1978 Solar thermal energy storage using heat of dilution: analysis of heat generation in multistage mixing column.

Energy Conversion 18:57-65.

749 Tanayeva, S.A.

1974 Investigation of the effective thermal conductivity of porous materials.

Heat Transfer-Soviet Research 6(2).

1763 Tang, D.H. and G.F. Pinder.

1979 A Direct solution to the inverse problem in groundwater flow. Advances in Water Resources 2(2):97-99. 
1530 Task Force 11.

1979 Grants and Loans for Municipal Water Supply and Wastewater Treatment Systems: Water Conservation Provisions. U.S. Dept. of Agriculture, U.S. Dept. of Commerce, U.S. Environmental Protection Ag., U.S. Dept. of Housing and Urban Dev.

1532 Task Force $5 \mathrm{a}$.

1980 Report of the Task Force on Non-Indian Federal Water Rights. U.S. Department of Interior, President's Water Policy Implementation. $122 \mathrm{pp}$.

1810 Taube, M., M. Furrer, E. Frick, B. Chevalley. Thermochemical system for the management of heat for LWRs. pp. 14-15 in Alternative Energy Technologies and Systems (General).

750 Taunton, J.W. and E.N. Lightfoot.

1970 Free convection heat or mass transfer in porous media. Chemical Engineering Science 25:1939-1945.

968 Tavener, G.F.

1967 Maximum drawdown in intermittently pumped we11s. Ground Water 5(1):29-42.

576 Taylor, $K$.

1976 The Influence of subsurface energy storage on seasonal temperature variations. Journal of Applied Meteorology 15(11):1129-1138.

1217 Taylor, 0.J.

1978 Summary Appraisals of the Nation's Ground-Water Resources: Mississippi Basin Region.

U.S. Geological Survey, Arlington. $41 \mathrm{pp}$. Professional Paper 813-0.

1552 Taylor-Beard, J., F.A. Iachetta, L.U. Lilleleht and J.W. Dickey.

1977 Annual Collection and Storage of Solar Energy for the Heating of Buildings.

University of Virginia, Mechanical Engineering Department, Charlottesville. 25 pp.

1128. Teledyne Brown Engineering, System Division.

1977 Final Design Report for Application of Solar Energy to Industrial Drying of Soybeans.

Teledyne Brown Engineering, Huntsville, AL. DOE ORO/5122-1.

1854 Telkes, M.

1965 Solar-Heat Storage. American Society of Mechanical Engineers, New York. 8 pp. $64-W A / S O L-9$. 
1855 Telkes, M.

1975 Thermal energy storage.

Energy 10: Tenth Intersociety Energy Conversion Engineering Conference. 111-115.

1259 Telkes, M. and E. Raymond.

1950 Storing solar heat in chemicals.

The Industrial Heating Engineer 12:119-123.

$1544 \mathrm{~g}$ Ternes, M.P.

1980 Thermal energy storage test facility.

Proceedings of the DOE Thermal and Chemical Storage Annual

Contractors' Review Meeting. 25-27.

$1544 h$

1980 Crawl space-assisted heat pump.

Proceedings of the DOE Thermal and Chemical Storage Annual

Contractors' Review Meeting. 28-31.

965 Terratek.

1977 Abstracts of Published Works.

Terratek, Salt Lake City, UT. 33 pp.

1218 Terry, J.E., R.L. Hosman, and C.T. Bryant.

1979 Summary Appraisals of the Nation's Ground-Water Resources: Lower Mississippi Region.

U.S. Geological Survey, Arlington. 41 pp. Professional Paper

$813-\mathrm{N}$.

16 Texas Energy and Mineral Resources.

1977 Groundwater aquifers for solar storage.

Texas Energy and Mineral Resources 3(7):4.

1127 The Engineering Foundation.

1977 Energy Storage, User Needs and Technology Applications. U.S. Energy Research and Development Administration, Technical Information Center, Springfield VA. 424 pp. CONF-760212.

1636 The Trane Company.

1977 Absorption Refrigeration.

The Trane Company, La Crosse, WI. 52 pp.

1637

1972 Absorption Operation Maintenance.

The Trane Company, La Crosse, WI. 46 pp. AM-FNDA-772.

1978 Design Considerations for Central Chilled Water Plant Installations.

The Trane Company, Applications Engineering Bulletin, La Crosse, WI. 20 pp. EB APR-6 $778 \mathrm{P} / \mathrm{S}$. 
1639 The Trane Company.

1973 Control of Two Absorption Unit System.

The Trane Company, La Crosse, WI. 24 pp. AM-CON-12-73.

1640

1973 Control of Turbine Absorption Combination.

The Trane Company, La Crosse, WI. 17 pp. AM-CON5-173.

490 Theis, C.V.

1935 The Relation between the lowering of the piezometric surface and the rate and duration of discharge of a well using groundwater storage.

Transactions, American Geophysical Union 2:519-524.

491

1938 The Significance and nature of the cone of depression in ground-water bodies.

Economic Geology 33:889-902.

492 Thomas, H.E.

1955 Water Rights in Areas of Ground-Water Mining. U.S. Geological Survey, Arlington. $16 \mathrm{pp}$. Circular 347.

1961 Ground Water and the Law.

U.S. Geological Survey, Arlington. 6 pp. Circular 446.

1219 Thomas, H.E. and D.A. Phoenix.

1976 Summary Appraisals of the Nation's Ground-Water Resources: California Region.

U.S. Geological Survey, Arlington. 51 pp. Professional Paper 813-E.

494 Thompson, G.A. and D.B. Burke.

1974 Regional geophysics of the Basin and Range Province.

Annual Review of Earth and Planetary Science. 2:213-238.

1582aa Thoms, R.L.

1980 Laboratory studies of rock salt.

Mechanical, Magnetic, and Underground Energy Storage 1980 Annual Contractors' Review. pp. 195-205, CONF-801128.

1482ap Thomson, W.B., A.Z. Frangos and T.H. Springer.

1980 Air/rock storage for solar central receiver power stations. Energy to the 21st Century: 15th Intersociety Energy Conversion Engineering Conference, Seattle, WA, August 18-22. 1:254-258.

495 Thorsteinsson, $T$.

1975 Redevelopment of the Reyk ir Hydrothermal System in Southwestern Iceland.

Proceedings of the Second U.N. Symposium on the Development and Use of Geothermal Resources. 3:2173-2180. 
1730 Tilton, B.E., G.L. Keller and P.J. Lacher.

1979 Application of Central Receivers to Solar Utilities in Canada. McDonne 11 Douglas Astronautics Company, Huntington Beach, CA. 58 pp. MDC G7883.

1058 Timmerman, R.W.

1978 Utilizing power plant waste heat.

Heating/Piping/Air Conditioning 50(5):91-97.

869 Tinker, G.E., R.W. Bowman, and G.A. Pope.

1976 Determination of in-situ mobility and wellbore impairment from polymer injectivity data.

Journal of Petroleum Technology 28:586-596.

940 Tinsley, J.M. and J.R. Williams, Jr.

1975 A New method for providing increased fracture conductivity and improving stimulation results. Journal of Petroleum Technology 27:1319-1325.

1294 Tison, R.R., N.R. Baker, B.D. Yudow, D.L. Sala, T.D. Donakowski and P.F. Swenson.

1979 Heat Pump Centered Integrated Community Energy Systems: System Development; Consolidated Natural Gas Service Company Interim Report. Argonne National Laboratory, Argonne, IL. ANL/CNSV-TM-7.

11770 Tleimat, B.W., A.D.K. Laird, H. Rie and I.C. Hsu.

1978 Heat transfer coefficiel,ts for isobutane.

Pages 47-49 in Earth Sciences Division Annual Report, Lawrence Berkeley Laboratory, Berkeley, CA. LBL-8648.

574 Todd, D.K.

1964 Economics of Groundwater Recharge by Nuclear and Conventional Means.

University of Cal ifornia, Lawrence Radiation Laboratory, Livermore, CA. $135 \mathrm{pp}$. UCRL-7850.

496 Tolivia M., E.

1970 Corrosion measurements in a geothermal environment.

U.N. Symposium on the Development and Utilization of Geothermal Resources. 2(2):1596-1601.

1890 Tolley, G.S.

1977 Methodology of Evaluating Research and Development Projects:

Final Report.

Chicago University. $445 \mathrm{pp}$. C00/4128-1. (Microfiche).

497 Tolman, C.F. and J.F. Pol and.

1940 Ground-water, salt-water infiltration and ground-surface recession in Santa Clara Valley, Santa Clara County, Calif. Transactions, American Geophysical Union 21:23-25. 
941 Toronyi, R.M. and S.M. Farouq-Ali.

1975 Two-Phase, Two-Dimensional Simulation of Geothermal Reservoir and the Wellbore System.

Society of Petroleum Engineers of AIME, Dallas, 27 pp. SPE 5521.

1480 Toth, W.J. and F.C. Paddison.

1979 Geothermal .energy markets on the Atlantic Coastal Plain. Energy Technology VI: Proceedings, Energy Technology Conference, Government Institutes Inc., Washington, DC. 881-889.

751 Townsend, S.J.

1976 Economic implications of the CANHO $\mathrm{H}_{2} / \mathrm{O}_{2}$ MHD energy storage system employing hydrogen as the re-cycled energy carrier for dedicated use within an electric power plant. First World Hydrogen Conference, Volume 3, Session 8C. (Abstract).

870 Trantham, J.C., H.L. Patterson, Jr., and D.F. Boneau.

1978 The North Burbank Unit: tract 97 surfactant/polymer pilot-operation and control. Journal of Petroleum Technology 30:1068-1074.

1452 Trescott, P.C., G.F. Pinder and S.P. Larson.

1976 Techniques of Water-Resources Investigations of the USGS:

Chapter Cl-Finite-Difference Model for Aquifer Simulation in 2 Dimensions with Results of Numerical Experiments.

U.S. Geological Survey, Arlington. $116 \mathrm{pp}$.

498 Treseder, R.S. and R. Wieland.

1976 Down-Hole Corrosion in a Salton Sea Geothermal Well. Society of Petroleum Engineers of AIME, Dallas. 241-245. SPE 6613.

1391 Triege1, E.K.

1978 Environmental aspects of the LTTES thermal storage in aquifers project. Energy Technology: 3rd Annual Proc of Thermal Energy Storage Contractors Info Exch Mt, Springfie1d, VA. 105-113. CONF-781231

499 Truesdel1, A.H.

1975 Summary of section 3: geochemical techniques in exploration. Proceedings of the Second U.N. Symposium on the Development and use of Geothermal Resources. 1:1(3)-1(24).

500 Truesde11, A.H. and W. Singers.

1974 The Calculation of aquifer chemistry in hot-water geothermal systems. Journal of Research, U.S. Geological Survey 2(3)271-278.

1258 Try Agricultural Research Service.

1969 Selected Water Resources Abstracts: Water Quality Management and Protection-Field 05, Waste Treatment Processes-Group 5D. 
Try Agricultural Research Service, Phoenix. Volume 2. 31 pp.

501 Tsang, C.F.

1979 A Review of Current Aquifer Thermal Energy Storage Projects. Lawrence Berkeley Laboratory, Earth Sciences Division, Berkeley, CA. 32 pp. LBL-9211.

551

1978 A Summary of current studies in aquifer thermal energy storage. The Second International Helioscience Institute Conference on Alternative Energy, Palm Springs, CA, Apr 8-11. 14 pp. CONF 7804.

552

1978 Aquifer thermal energy storage.

Institute of Gas Technologies Symposium on Advanced Technology for Storing Energy. 28 pp. LBL-7070.

$1383 a t$

1980 Seasonal thermal energy storage in aquifers: mathematical modeling studies in 1979.

Thermal Energy Storage: Fourth Annual Review Meeting, Tysons Corner, VA, Dec. 3-4, 1979. 581-590. CONF-791232.

$1582 p$

1980 Aquifer thermal energy storage studies at Lawrence Berkeley Laboratory in 1980.

Mechanical, Magnetic, and Underground Energy Storage 1980 Annual

Contractors' Review. pp. 108-114. CONF-801128.

1672

1980 Trip Report: Tel Aviv, Rehovot, London, Amsterdam and Mons, October 21 - November 9.

Lawrence Berkeley Laboratory, Berkeley, CA.

1911

1980 Theoretical Studies in Long-Term Energy Storage in Aauifers. Lawrence Berkeley Laboratory, Berkeley, CA. 12 pp. LBL-11593.

598 Tsang, C.F. (translator).

1977 Artificial Recharge into Groundwater Systems.

Chinese National Geology Department at Beijing, City of Shanghai

Hydrogeological Team. [in Chinese with English summary].

1242 Tsang, C.F., C.B. Goranson, M.J. Lippmann, and P.A. Witherspoon.

1977 Modeling underground storage in aquifers of hot water from solar power systems.

Proceedings, Annual Meeting American Section of the International

Solar Energy Society. 1:16-20-16-24.

1603 Tsang, C.F., D. Hopkins and F. Hellstrom.

1980 Aquifer Thermal Energy Storage: A Survey.

Lawrence Berkeley Laboratory, Berkeley, CA. 45 pp. LBL-10441. 
1604 Tsang, C.F., F.J. Molz and A.D. Parr.

1980 Experimental and Theoretical Studies of Thermal Energy Storage in Aquifers. Lawrence Berkeley Laboratory, Berkeley, CA. 5 pp. LBL-10889.

9999r Tsang, C.F., G. Bodvarsson, M.J. Lippmann and R.J. Rivera.

1978 Study of Alternative Reinjection Schemes for the Cerro Prieto Geothermal Field, Baja California, Mexico.

Geothermal Resources Council Annual Meeting: Geothermal Energy-A Novelty Becomes Resource, Hilo, HI, July 25-27. S.2, pp. 659-662.

1177 ag Tsang, C.F., G.S. Bodvarsson, M.J. Lippmann and J. Rivera R.

1978 Study of alternative reinjection schemes for the Cerro Prietc geothermal field, Baja California, Mexico.

Pages 119-123 in Earth Sciences Division Annual Report, Lawrence Berkeley Laboratory, Berkeley, CA. LBL-8648.

504 Tsang, C.F., M.J. Lippmann, C.B. Goranson, and P.A. Witherspoon.

1977 Numerical Modeling of Cyclic Storage of Hot Water in Aquifers. Lawrence Berkeley Laboratory, Berkeley, CA. LBL-5929.

1595 Tsang, C.F., M.J. Lippmann and P.A. Witherspoon.

1978 Underground aquifer storage of hot water from solar energy collectors.

International Solar Energy Society-UK Section, Sun: Mankind's

Future Source of Energy Conference. 1:490-495b.

502 Tsang, C.F., P. Fong, C.W. Miller and M.J. Lippmann.

1978 Daily Sensible Heat Storage in Aquifers for Solar Energy Systems. Lawrence Berkeley Laboratory, Berkeley, CA. 21 pp.

1177al Tsang, C.F., T. Buscheck, D. Mangold and M.J. Lippmann.

1978 Mathematical modeling of thermal energy storage in aquifers. Pages 139-143 in Earth Sciences Division Annual Report, Lawrence Berkeley Laboratory, Berkeley, CA. LBL-8648.

1602 Tsang, C.F., T. Buscheck and C. Doughty.

1980 Aquifer Thermal Energy Storage: A Numerical Simulation of Auburn University Field Experiments.

Lawrence Berkeley Laboratory, Berkeley, CA. 44 pp.

1649. Tsang, C.F. and J. Claesson.

1980 Energy storage in aquifers: a survey of recent theoretical studies.

Rockstore 80, Stockholm, Sweden. 8 pp. CONF-8006102--1.

503 Tsang, C.F. and M.J. Lippmann.

1977 Thermal energy storage in aquifers.

pp. 9-13 in Earth Sciences Division Annual Report, Lawrence

Berkeley Laboratory, Berkeley, CA. LBL-7028. 
1534 Tsang, Y.W. and C.F. Tsang.

1978 Analytic Study of Geothermal Reservoir Pressure Response to Cold Water Reinjection. Lawrence Berkeley Laboratory, Berkeley, CA. 11 pp. LBL-9001.

505 Tull, R.H.

1966 New developments in heat-pump systems. Journal of ASHRAE 8(9):64-67.

506 Turcan, A.N.

1962 Estimating Water Quality From Electrical Logs. U.S. Geological Survey, Arlington. C135-C136. Professional Paper 450 .

1962 Estimating the specific capacity of a well. Paper 450-E, pp. 145-148 in U.S.G.S. Research, Short Papers in Geology, Hydrology, and Topography, Articles 180-239, U.S.G.S.

1796 Turchaninov, I.A., M.A. Iof is and E.V. Kasparyan.

1979 Principles of Rock Mechanics.

Terraspace, Inc., Rockville, MD. 493 pp.

1856 Turner, R.D.

1979 Superconducting Magnetic Energy Storage for Electric Power System Stabilization. American Chemical Society. 494-499. Paper no. 799101.

1157 Turner, R.H.

1978 High Temperature Thermal Energy Storage.

Frank lin Institute Press, Philadelphia, PA. 101 pp.

1979 High Temperature Thermal Energy Storage in Steel and Sand. Jet Propulsion Laboratory, Pasadena, CA. 93 pp. NASA-CR-159708.

1857 Tye, R.P., A.0. Desjarlais and J.G. Bourne. Thermophysical property measurements on thermal energy storage materials. Proceedings of the Seventh Symposium on Thermophysical Properties. 189-197.

769 U.S. Congress, Office of Technology Assessment.

1979 Materials and Energy from Municipal Waste: Resource Recovery and Recycling from Municipal Solid Waste and Beverage Container Deposit Legislation.

U.S. Congress, Office of Technology Assessment, Washington. 284 pp. OTA-M-93.

1322 U.S. Department Of Energy, Assistant Secretary for Conservation and Solar Energy. 
1980 Energy Storage Systems: Program Summary Document FY-1981. U.S. Department of Energy, Assistant Secretary for Conservation and Solar Energy.

1470 U.S. Department of Energy, Argonne National Lab, and Univ. of Illinois-Chicago Circle.

1979 Peak-load Pricing and Thermal Energy Storage: Proceedings, Chicago, IL; Ju1y 15-17, 1979.

U.S. Department of Energy, Argonne National Lab, and Univ. of Illinois-Chicago Circle. 169 pp.

1571 U.S. Department of Energy, Assistant Secretary for Energy Technology.

1978 Geothermal Energy Geopressure Subprogram: GCO-DOE Pleasant Bayou No. 1, Brazoria County Texas - Environmental Assessment. U.S. Department of Energy, Assistant Secretary for Energy Technology, Washington. DOE/EA-0013.

1195 U.S. Department of Energy, Asst. Secr. for Energy Technology and Asst. Secr. for Environment.

1979 Environmental Development Plan: Energy Storage Systems. U.S. Department of Energy, Assistant Secretary for Energy Technology and Assistant Secretary for Environment. DOE /EDP-004EC197.

771 U.S. Department of Energy, Division of Energy Storage Systems.

1979 Project Summary Data: Thermal and Mechanical Energy Storage Program, FY-1979.

U.S. Department of Energy, Division of Energy Storage Systems. 177 pp. DOE/ET-0091.

871

1977 Interagency Coordination Meeting on Energy Storage, September 14-15, Washington, DC. U.S. Department of Energy, Division of Energy Storage Systems. 145 pp. CONF-7709116.

1980 Project Summary Data: Thermal and Mechanical Energy Storage Program, FY 1980.

U.S. Department of Energy, Division of Energy Storage Systems, Washington. $187 \mathrm{pp}$. DOE/CS-0150.

1374 U.S. Department of Energy, Division of Solar Applications.

1979 Proceedings of 3rd Annual Solar Heating and Cooling Research and Development Branch Contractor's Meeting: September 24-27, 1978, Washington, D.C.

U.S. Department of Energy, Division of Solar Applications, Washington, $500 \mathrm{pp}$. CONF-780983.

766 U.S. Department of Energy, Electric Power Research Inst. and Pacific NW Lab., Battelle. 
1978 Compressed Air Energy Storage Symposium Proceedings, May 15-18, Pacific Grove, CA.

U.S. Dept. of Energy, Electric Power Research Inst. and Pacific Northwest Lab, Batte1le. 1:1-560. CONF-780599.

767 U.S. Department of Energy, Electric Power Research Inst. and

Pacific NW Lab., Battelle.

1978 Compressed Air Energy Storage Symposium Proceedings, May 15-18, Pacific Grove, CA.

U.S. Dept. of Energy, Electric Power Research Inst. and Pacific Northwest Lab, Batte11e. 2:560-1033. CONF-780599.

1489 U.S. Department of Energy, Office of Program Management Support.

1978 Uniform Contractor Reporting System Guidelines.

U.S. Department of Energy, Office of Program Management Support, Washington. Volume 1. DOE/CR-0001/2.

1544 U.S. Department of Energy, Office of Advanced Conservation

Technologies, Thermal and Chemical Storage Branch.

1980 Proceedings of the DOE Thermal and Chemical Storage Annual

Contractors' Review Meeting. McLean, VA, October 14-16.

U.S. Department of Energy, Office of Advanced Conservation

Technologies, Thermal and Chemical Storage Branch, Washington. $300 \mathrm{pp}$.

91 U.S. Department of Energy, Richland Operations Office.

1979 Program Opportunity Notice: Inviting Proposals for Preparation of a Conceptual Design for an Aquifer Thermal Energy Storage System for Seasonal Energy Storage.

U.S. Department of Energy, Richland Operations Office, Richland, WA.

942

1979 - Energy Meetings.

U.S. Department of Energy, Technical Information Center, Oak Ridge, TN.

1174 U.S. Department of Energy.

1978 Contract No. 78-01-4278: Chapters 3-13.

U.S. Department of Energy.

1326

1979 Office of Building and Community Systems: Multi-Year Plan, August 1979.

U.S. Department of Energy.

1979 Proceedings of the 1979 Mechanical and Magnetic Energy Storage Contractors' Review Meeting, August 1979.

U.S. Department of Energy. CONF-790854. 
1383 U.S. Department of Energy and NASA Lewis Research Center.

1980 Thermal Energy Storage: Fourth Annual Review Meeting, Tysons Corner, VA, Dec. 3-4, 1979.

U.S. Department of Energy, Washington, and NASA Lewis Research Center, Cleveland. 653 pp. CONF-791232.

1305 U.S. Dept. of Energy, Asst. Secr. for Energy Tech., Div. of Geothermal Energy.

1977 Proceedings: NATO-CCMS Conference on the Economics of Direct Uses of Geothermal Energy, June 21-22.

U.S. Dept. of Energy, Asst. Secr. for Energy Tech., Div. of Geothermal Energy, Washington.357 pp. CONF-770681.

1119 U.S. Dept. of Energy, Office of Industrial Applications and Commercialization.

1978 Basic Process Data on the Potential for Low Level Waste Heat Recovery in the Petroleum Refining and Selected Chemical Industries of the West South Central U.S.

U.S. Department of Energy, Office of Industrial Applications and Commercialization. $134 \mathrm{pp}$. HCP/M5056-02.

1635 U.S. Dept. of Energy, U.S. Dept. of Housing and Urban Dev. and Int'l District Heating Assn.

1980 Co-Sponsored Third Quarter Progress Review Conference on District Heating, October 1.

U.S. Department of Energy, U.S. Department of Housing and Urban Development and Internation District Heating Association.

1554 U.S. Energy Research and Development Administration, Division of Building and Industry.

1975 The International Energy Agency with Emphasis on the Subgroup on Energy Research and Development and the Energy Conservation Working Party. U.S. Energy Research and Development Administration, Division of Building and Industry, Office of Conservation. $34 \mathrm{pp}$.

1153

Solar Energy.

1974 Solar Energy for Agriculture and Industrial Process Heat: Program Summary. U.S. Energy Research and Development Administration, Division of Solar Energy, Washington, 91 pp. ERDA 77-72 1977.

200 U.S. Energy Research and Development Administration, International Activities.

1977 Hearing Before a Subcommittee of the Committee on Government Operations, House of Representatives: 91st Congress, 1st Session, May 12, 1977.

U.S. Government, Washington. $332 \mathrm{pp}$. 
1237 U.S. Energy Research and Development Administration.

1977 Solar Energy for Agriculture and Industrial Process Heat. U.S. Energy Research and Development Administration, Division of Solar Energy, Washington, DC. (Microfiche) ERDA-77-72.

783 U.S. Energy Research and Development Administration and Electric Power Research Institute.

1975 Proceedings of the Workshop on Compressed Air Energy Storage System, Dec. 18-19, Arlie House, VA. Energy Research and Development Administration and Electric Power Research Institute. 551 pp. ERDA-76-124.

774 U.S. Environmentals Protection Agency, Office of Water Supply. 1979 Manual of Water Well Construction Practices. U.S. Environmental Protection Agency, Office of Water Supply. $156 \mathrm{pp}$. EPA 570/9-75-001.

110 U.S. Environmental Protection Agency.

1979 Draft Consolidated Permit Application Forms and Proposed National Pollutant Discharge Elimination System Regulations. Federal Register 44(116):34345-34416.

1979 Proposed Consolidated Permit Regulations. Federal Register 44(116):34244-34344.

1979 Water Programs, State Underground Injection Control Programs, Minimum Requirements and Grant Regulations.

Federal Register 44(78):23728-23767.

1979 A Guide to the Underground Injection Control Program. U.S. Environmental Protection Agency, Office of Drinking Water. WH550.

1976 Quality Criteria for Water.

U.S. Environmental Protection Agency, Washington. $256 \mathrm{pp}$.

113 U.S. Environmental Protection Agency and National Water Well Association.

1971 Proceedings of the National Ground Water Quality Symposium. U.S. Environmental Protection Agency and National Water Well Association. $211 \mathrm{pp}$.

1155 U.S. Executive Office of the President, Office of Management and Budget.

1972 Standard Industrial Classification Manual. U.S. Executive Office of the President, Office of Management and Budget. $649 \mathrm{pp}$ and 1977 Supplement. 
1180 U.S. Geological Survey.

1962 Short Papers in Geology, Hydrology, and Topography: Articles 120-179. U.S. Geological Survey, Arlington. 194 pp. Professional Paper $450-D$.

1181

1962 Short Papers in Geology, Hydrology, and Topography: Articles 180-239. U.S. Geological Survey, Arlington. 189 pp. Professional Paper $450-E$.

1182

1963 Geological Survey Research 1963, Short Papers in Geology and Hydrology: Articles 1-59.

U.S. Geological Survey, Arlington. 219 pp. Professional Paper $475-8$.

1712

1979 Nawdex National Water Data Exchange: Identification Codes for Organizations Listed in Computerized Data Systems of the U.S. Geological Survey.

U.S. Geological Survey, Reston, VA. 80 pp. Open-File Report $79-331$.

1773

1980 Scientific and Technical, Spatial and Bibliographic Data Bases of U.S. Geological Survey 1979.

U.S. Geological Survey. Circular C-817.

1670 U.S. House of Representatives.

1980 Energy Security Act.

U.S. House of Representatives, 96th Congress, 2nd Session. 321 pp. Report No. 96-1104.

575 U.S. Nuclear Regulatory Commission, Office of Nuclear Material Safety and Safeguards.

U.S. Nuclear Regulatory Commission, Washington, DC. (Microfiche).

775 U.S. Nuclear Regulatory Commission, Office of Nuclear Reactor Regulations.

1975 Final Environmental Statement: South Texas Project, Units 1 and

- 2, Houston Power and Light Co. U.S. Nuclear Regulatory Commission, Office of Nuclear Reactor Regulations. NUREG-75/019.

778 U.S. Nuclear Regulatory Commission, Office of Nuclear Reactor Regulations.

1979 Environmental Standard Review Plans for the Environmental Review of Construction Permit Applications for Nuclear Power Plants. 
U.S. Nuclear Regulatory Commission, Office of Nuclear Reactor Regulations. NUREG-0555.

1271 U.S. Nuclear Regulatory Commission and U.S. Department of Interior.

1978 Final Site Environmental Statement: Sundesert Nuclear Plant Units 1 and 2.

U.S. Nuclear Regulatory Commission and U.S. Department of Interior, Office of Nuclear Reactor Regulation. Vol. 1. NUREG-0455.

1272 U.S. Nuclear Regulatory Commission and U.S. Department of Interior.

1978 Final Site Environmental Statement: Sundesert Nuclear Plant Units 1 and 2 .

U.S. Nuclear Regulatory Commission and U.S. Department of Interior, Office of Nuclear Reactor Regulation. Vol. 2. NUREG-0455.

874 U.S. Patent Documents.

1979 Water-Borne Rotation Solar Collecting and Storage Systems. U.S. Patent 4,148,301, Sheet 1-3.

1787 U.S. Water Resources Council.

1978 The Nation's Water Resources 1975-2000: Sumary. U.S. Water Resources Council, Washington. Vol. 1. 86 pp.

1059 Uehara, $H$.

1979 Research and Development on Ocean Thermal Energy Conversion in Japan.

American Chemical Society, Washington, DC. 2088-2034.

1316 United Nations.

1975 Ground-Water Storage and Artifical Recharge: Natural

Resources/Water Series No. 2.

United Nations Publication, New York. ST/ESA/13.

1742 United Technologies Corporation.

1980 Cogeneration Technology Alternatives Study: Volume 1, Summary Report.

United Technologies Corporation, South Windsor, CT. 119 pp. DOE/NASA/0030-80/1.

1150 University of Maryland, Department of Mechanical Engineering.

1976 Proceedings of Solar Industrial Process Heat Workshop, College Park, Maryland, June 28-29, 1976.

U.S. Energy Research and Development Administration, Division of Solar Energy. $73 \mathrm{pp}$. CONF-760655.

1582d University of Minnesota.

1980 Concept design of Aquifer Thermal Energy Storage System, St. Paul Campus, University of Minnesota.

Mechanical, Magnetic, and Underground Energy Storage 1980 Annual 
Contractors' Review. pp. 18-26. CONF-801128.

1060 Urdaneta-Bohorquez, A.H.

1978 Energy and Economic Analysis of Industrial Process Heat Recovery with Heat Pumps.

Metallurgy Engineering 3566-B. (Abstract).

1725 Urquhart, D.A.

1979 Implications of Vacuum Protected and Photovoltaic Solar Collectors: Feasibility of the Central Receiver Solar Utility. Spectral Engineering Ltd., Toronto. 23 pp.

1442 Utah Roses, Inc.

1978 Floral Greenhouse Industry Geothermal Energy Demonstration Project: Vol.1 - Technical Proposal. Utah Roses, Inc., Sandy, UT. 48 pp.

1829 Vaccari, J.A.

1979 Materials: key to new energy storage systems. Product Engineering Jan:46-49.

9999eg Vachaud, G. and J.Y. Ausseur.

1979 System for interseasonal earth storage of solar heat for individual housing.

Sun 2: Proceedings of the International Solar Energy Society Silver Jubilee Congress, Atlanta, GA, May 1979. 1:625-628.

1876 Vakil, H.B. and J.W. Flock.

1978 Closed Loop Chemical Systems for Energy Storage and Transmission: Chemical Heat Pipe.

General Electric Co., Power Systems Laboratory, Schenectady, NY. 448 pp. C00-2676-1. (Microfiche).

507 Van Der Held, E.F.M. and F.G. Van Drunen.

1949 A Method of measuring the thermal conductivity of liquids. Physica $15(10): 865-881$.

753 Van Everdingen, A.F.

1953 The Skin effect and its influence on the productive capacity of a well. Petroleum Transactions, AIME 198:171-176.

752 Van Everdingen, A.F. and W. Hurst.

1949 The Application of the Laplace transformation to flow problems in reservoirs. Petroleum Transactions, AIME 1:305-326.

754 Van Poolen, H.K.

1964 Radius of drainage and stabilization time equations. $0 i 1$ and Gas Journal Sep14:138-144. 
1061 Van Schelt, J.E., Jr.

1979 Bringing Advanced Technology to Bear in Energy Conservation.

American Chemical Society, Washington, DC. 1635-1638.

1859 Van Vechten, J.A.

1974 Latent-heat energy storage is feasible.

Electrical World Aug15:41.

1453h Vandermolen, J.H.C.

1979 On load brush cleaning systems for chiller condensers and other tube type heat exchanger.

Official Proceedings, 70th Annual Conference of the International

District Heating Assn. June 18-20. Section 13.

1805 Varnado, S.G.

1980 Geothermal drilling research in the U.S.

Lat in American Congress on Drilling, Mexico City, Oct.

SAND-80-1581C.

755 Vasek, F.C., H.B. Johnson, and D.H. Eslinger.

1975 Effects of pipeline construction on cresote bush scrub vegetation of the Mojave Desert.

Madrono 23(1):1-64.

1427 Vecchioli, J., H.F.H. Ku and D.J. Sulam.

1980 Hydraulic Effects of Recharging the Magothy Aquifer, Bay Park, New York with Tertiary-Treated Sewage.

U.S. Geological Survey, Arlington. Professional Paper 751-F. 21 pp.

1683 Vecchioli, J. and H.F.H. Ku.

1972 Preliminary Results of Injecting Highly Treated Sewage-Plant Effluent Into a Deep Sand Aquifer at Bay Park, New York. U.S. Geological Survey. $14 \mathrm{pp}$. Professional Paper 751-A.

1111 Venkatesetty, H.V. and R.T. LeFrois.

1976 Thermal energy storage for solar power plants.

11 th Intersociety Energy Conversion Engineering Conference. $1: 606-612$.

1860 Verma, A.

1978 Medium-temperature heat storage in sodium sulphate.

CIM Bulletin Nov:84-90.

1861 Verma, A., K.E. Johnson and E.0. Sherman.

1976 Thermal Energy Storage in Inorganic Salts.

The Canadian Journal of Chemical Engineering 54Aug:285-289.

508 Vetter, 0.J., D.A. Campbe11, and M.J. Walker.

1978 Geothermal Fluid Investigations at RGI's East Mesa Test Site:

Part 1. Experience with Field Test Loops.

Pacific Northwest Laboratory, Battelle, Richland, WA. 116 pp.

PNL-2556. 
1365 Vetter, 0.J., D.A. Campbe11, and M.J. Walker.

1978 Summary of Geothermal Fluid Investigations at Republic's East Mesa Site.

U.S. Department of Energy. $12 \mathrm{pp}$.

509 Vetter, 0.J. and R.C. Phillips.

1970 Prediction of deposition of calcium sulfate scale under down-hole conditions.

Journal of Petroleum Technology 22:1299-1308.

549 Vetter, 0.J. and D.A. Campbell.

1979 Scale Inhibition in Geothermal Operations: Experiments with Dequest 2060 Phosphonate in Republic's East Mesa Field. Lawrence Berkeley Laboratory, Earth Sciences Division, Berkeley, CA. GREMP -5. LBL-9089.

1462 Villas, R.N. and D. Norton.

1977 Irreversible mass transfer between circulating hydrothermal fluids and the Mayflower stock. Economic Geology 72:1471-1504.

1661 Vitro Engineering Corporation and Pacific Northwest Laboratory, Battelle.

1979 Preliminary Conceptual Design for High Temperature Leading Edge Test Facility.

Vitro Engineering Corporation and Pacific Northwest Laboratory, Battelle, Richland, WA. (Draft).

756 Vollmar, A.T., B.G. Maza, P.A. Medica, F.B. Turner, and S.A. Bamberg.

1976 The Impact of off-road vehicles on a desert ecosystem. Environmental Management 1(2):115-129.

$1360 \mathrm{v}$ Von Fuchs, G.

1979 Rock bed computer mode1. Proceedings of Solar Energy Storage Options, San Antonio, TX, March 19-20. 1:547-560. CONF-790328-P2.

1669 Von Karman Institute for Fluid Dynamics.

1979 Fluid Dynamics of Porous Media In Energy Applications. Van Karman Institute for Fluid Dynamics, St. Genese, Belgium. Lecture Series 1979-4. Volume 1. N80-12338.

510 Vonder Haar, S. and I.P. Cruz.

1979 Fault intersections and hybrid transform faults in the Southern Salton Trough Geothermal Area, Baja Calif., Mexico. Geothermal Resource Council Annual Meeting, Reno, NV. pp. 1-4. 
1724 Wachte11, G.P.

1978 Self Controlling, Self Pumping Heat Circulation System Study. Franklin Research Center, Philadelphia. C00-4484-07.

1291 Wade, D.W., B.S. Dixit, B.C. Tramme1, D.C. McCurry and B.A. Rindt.

1979 Heat Pump Centered Integrated Community Energy Systems: System Development; Georgia Institute of Technology Interim Report. Argonne National Laboratory, Argonne, IL. 189 pp. ANL/ICES-TM-28.

872 Wagner, 0.R.

1977 The Use of tracers in diagnosing interwell reservoir heterogeneities - field results. Journal of Petroleum Technology 29:1410-1415.

1425 Wahl, E. and I. Yen.

1975 Scale deposition and control research for geothermal utilization. Proceedings of the Second U.N. Symposium on the Development \& Use of Geothermal Resources, San Francisco, May 20-29. 1855-1864.

548 Waldschmidt, W.A.

1941 Cementing materials in sandstones and their probable influence on migration and accumulation of $0 i l$ and gas. Bulletin, American Association Petroleum Geologists $25(10): 1839-1879$.

614 Walker, W.R. and W.E. Cox.

1974 Subsurface environment: private property or public domain? Journal of the Hydraulics Division, ASCE 100(HY 11):1699-1705.

1976 Deep Well Injection of Industrial Wastes: Government Controls and Legal Constraints. Virginia Water Resources Research Center, Blacksburg, VA. 163 pp.

1467 Wallace, G.G. (ed).

1979 Standard Distribution for Unclassified Scientific and Technical Reports: Arranged by Category Number.

U.S. Department of Energy, Technical Information Center, Springfield, VA. 204 pp.

757 Wallick, G.C. and J.S. Aronofsky.

1954 Effect of gas slip on unsteady flow of gas through porous media: experimental verifications. Journal of Petroleum Technology 239:27-29.

1298 Walling, F.B., and L.E. Ottis, Jr.

1967 Water Requirements of the Iron and Steel Industry. U.S. Geological Survey, Arlington. Water-Supply Paper $1330-\mathrm{H}$.

1221 Walters, K.L.

1962 Highly Productive Aquifers in the Tacoma Area, WA. Paper 450-E, pp. 157-158 in U.S.G.S. Research, Short Papers in Geology, Hydrology, and Topography, Articles 180-239, U.S.G.S. 
873 Walton, W.C.

1962 Selected Analytical Methods for Well and Aquifer Evaluation. Illinois State Water Survey, Urbana, I1. 81 pp. Bulletin No. 49.

1367 Wapora Inc.

1976 Survey of Environmental Regulations Applying to Geothermal Exploration, Development, and Use: Phase 1. Wapora Inc., Washington, DC. 97 pp. Project 658. (Draft).

511 Ward, J.C.

1964 Turbulent flow in porous media. Journal of the Hydraulics Division, ASCE 90(HY5):1-12.

512 Warman, J.C., F.J. Molz and T.E. Jones.

1976 Step beyond theory: aquifer storage of energy. Proceedings of the Second Southeastern Conference on Application of Solar Energy. 476-487. CONF-760423.

1977 Subsurface Waste Heat Storage: Experimental Study. Auburn University, Water Resources Research Institute. 0R0/5003-1.

1369 Warner, D.L.

1970 Regulatory aspects of liquid waste injection into saline aquifers. Water Resources Research 6(5):1458-1463.

1335 Warner, D.L., L.F. Koederitz, A.D. Simon and M.G. Yow.

1979 Radius of Pressure Influence of Injection We11s. University of Missouri at Rolla. 203 pp. EPA-600/2-79-170.

514 Warner, D.L. and J.H. Lehr.

1977 An Introduction to the Technology of Subsurface Wastewater Injection.

National Water Wel1 Association, Worthington, OH. EPA-600/2-77-240.

1976 Criteria for injection well site evaluation. pp.124-156 in An Introduction to the Technology of Subsurface Wastewater Injection, Nat. Water Well Assoc., Worthington, $\mathrm{OH}$.

132 Washington (State).

Geothermal Drilling Rules and Regulations.

Washington Administrative Code, Chapter 332-17. 0TS-768:3.

391 Washington (State), Department of Natural Resources, $0 i 1$ and Gas Conservation Committee.

1954 Instructions for $0 i 1$ and Gas Drillers.

State of Washington, Department of Natural Resources, 0lympia, WA. 
392 Washington (State), Department of Natural Resources, 0il and Gas Conservation Committee.

1954 General Rules and Regulations Governing the Conservation of $0 i 1$ and Gas.

State of Washington, Department of Natural Resources, $01 y m p i a$, WA. $24 \mathrm{pp}$.

397 Washington (State) Department of Natural Resources.

$19510 i 1$ and Gas Conservation Act.

State of Washington, Department of Natural Resources, 01 ympia, WA. Chapter 146. House Bil1 143. 20 pp.

1124 Washington Scientific Marketing, Inc.

1978 Department of Energy Programs and Objectives: Fluid Waste Heat Recovery and Utilization. Washington Scientific Marketing, Inc. Washington, DC. $34 \mathrm{pp}$. TID-28393.

1976 Proceedings of the Energy Research and Development Administration Workshop on Fluid Waste Heat Recovery and Utilization.

Washington Scientific Marketing, Inc., Washington, 120 pp. CONF-761157.

866 Water Information Center.

1980- The Ground Water Newsletter. Water Information Center, Syosset, NY. 9(4,5,7,9-14,16-).

389 Water Well Journal Publishing Co.

1971 NWWA ground water heat pump research imperatives. Water Well Journal 25(3):60-61.

1976 Records and drilling reports. Water Well Journal 30(1):30-31.

1977 Water Wel1 Journal funds heat pump research. Water Well Journal 31(8):45.

1963- Ground Water. Water Well Journal Publishing Co. $1(3), 2(1,4), 7(1), 8(5)$, $9(4), 10(2), 11(2), 13(2), 18(1)$.

1980 Using nonmetallic casing for geothermal wells. Water Well Journal 34(4):90-91. 
1511 Water Well Journal Publishing Co.

1974- Water We11 Journa1. Water We11 Journal Publishing Co., Worthington, OH. 28(9,10), $29(1,2), 34(1-)$.

1567

1980 - Ground Water Heat Pump Journa1. Ground Water Heat Pump Journal 1- .

1719

1980 Summary of state wel1 construction regulation and enforcement. Water We11 Journa1 34(10):52-54.

1062 Waters, E.D., E.W. Saaski and W.R. Martini.

1979 A Thermal Energy Storage System for a Stirling Engine Powered Highway Vehicle.

American Chemical Society, Washington, DC. 475-480.

1063 Watkins, J.J.

1979 The St. Regis Hydropyrolysis Process - An Approach to Energy Conservation in the Pulp and Paper Industry. American Chemical Society, Washington, DC. 1639-1643.

1801 Watson, J.C.

1978 Sampling and Analysis Methods for Geothermal Fluids and Gases. Pacific Northwest Laboratory, Battelle, Richland, WA. PNL-MA-572.

758 Waxman, M.H. and E.C. Thomas.

1974 Electrical conductivities in shaly sands: part 1 and part 2. Journal of Petroleum Technology 26:213-225.

$1482 \mathrm{cw}$ Weast, T.E., L.J. Shannon and K.P. Ananth.

1980 Study of thermal energy storage using fluidized bed heat exchangers.

Energy to the 21st Century: 15th Intersociety Energy Conversion Engineering Conference, Seattle, WA, August 18-22. 1:619-623.

1616 Weast, T. and L. Shannon.

1980 Thermal Energy Storage Systems Using Fluidized Bed Heat Exchangers.

Midwest Research Institute, Kansas City, M0. 204 pp. DOE/NASA/0096-1.

759 Webb, R.H., H.C. Ragland, W.H. Godwin, and D. Jenkins.

1978 Environmental effects of soil property changes with off-road vehicle use.

Environmental Management 2(3):219-233.

516 Weber, E.L.

1963 Heat pump employs panel heating as refrigerant condenser. Heating, Piping and Air Conditioning 35(10):95-97. 
875 Weber, K.J., P.H. Klootwijk, J. Konieczek, and W.R. van der Vlugt.

1978 Simulation of water injection in a barrier-bar-type, oil-rim reservoir in Nigeria.

Journal of Petroleum Technology 30:1555-1565.

945 Week 1 y Energy Report.

1976 Energy: the darkening 1 andscape.

Week ly Energy Report 4(12):1-2.

1505 Weeks, E.P.

1969 Determining the ratio of horizontal to vertical permeability by aquifer-test analysis.

Water Resources Research 5(1):196-214.

946 Weeks, S.G. and G.F. Farris.

1976 Continuous bottom-hole pressures are measured by nonelectric system.

$0 i 1$ and Gas Journal 74(1):68-71.

517 Wehlage, E.F.

1976 Geothermal energy needed: effective heat transfer equipment. Mechanical Engineering 98:27-33.

518 Weinbrandt, R.M., H.J. Ramey Jr. and F.J. Casse.

1972 The Effect of temperature on relative and absolute permeability of sandstones.

Society of Petroleum Engineers Journal 12(10):376-384.

519 Weissenbach, P.B.

1974 Langzeitspeicherung fur niedrigtemperaturwarme. VDI-Berichte NR 223:39-44.

1222 Weist, W.G., Jr.

1978 Summary Appraisals of the Nation's Ground-Water Resources: Great Lakes Region.

U.S. Geological Survey, Arlington. $30 \mathrm{pp}$. Professional Paper 813-J.

1825 Wentworth, W., C. Batten, T. Schuler, J. Ibanez, L. Lopez, C. Cook, E. Chen, and J. Ray.

1978 The storage and regeneration of high temperature thermal energy by means of reversible chemical reactions the ammonium hydrogen sulfate system.

Proceedings of the 1978 Annual Meeting of the American Section of the International Solar Energy Socity, Inc. 985-989.

1818 Wentworth, W.E., A.F. Hildebrandt, C.F. Batten, G.E. Corbett, E.C.M. Chen.

1978 Thermal chemical conversion cycles for storage of solar energy. Rev. int. Hautes Temp. Retract, Fr. 15:231-136. 
547 Wentworth, W.E. and E. Chen.

1976 Simple thermal decomposition reactions for storage of solar thermal energy.

Solar Energy 18(3):205-214.

947 Wenze1, L.K.

1942 Methods for Determining Permeability of Water-Bearing Materials with Special Reference to Discharging-Well Methods. U.S. Geological Survey, Arlington. 189 pp. Water-Supply Paper 887 .

1389 Weres, 0., K. Tsao and B. Wood.

1977 Resource, Technology and Environment at the Geysers. Lawrence Berkeley Laboratory, Berkeley, CA. pp. XII8-XII9.

520 Werner, D. and K.D. Balke.

1977 Die warmeausbreitung in der umgebung eines kuhlwasser-sickerbrunnens. GWF-Wasser/Abwasser 118:528-531.

521 Werner, D. and W: Kley.

1977 Problems of heat storage in aquifers. Journal of Hydrology $34: 35-43$.

1869 Wessling, F.C.

1974 Thermal Energy Storage in Adobe and in Stone Structures. American Society of Mechanical Engineers, New York. 7 pp. 74-WA/HT-15.

522 West, E.R.

1976 Improved drilling is a result of sound engineering. World 0 il 183:57-59.

1223 West, S.W. and W.L. Broadhurst.

1975 Summary Appraisals of the Nation's Ground-Water Resources: Rio Grande Region.

U.S. Geological Survey, Arlington. 39 pp. Professional Paper 813-D.

1461 Westermann, J.

Seasonal Thermal Energy Storage: Temperature Measuring Tube and Experimental Results. RISO National Laboratory, Denmark.

546 Westinghouse Study.

1973 Solar Energy for Heating and Cooling of Buildings. Westinghouse. 171-173.

1650 Wettermark, G., B. Carlsson and H. Stymne.

1979 Storage of Heat: A Survey of Efforts and Possibilities.

Swedish Council for Building Research, Stockholm. PB-295936. 
1342 Wettermark, G., and J. Kowalewska.

1976 Storage of Low-Temperature Heat: Solar Energy Thermal Storage. Royal Institute of Technology, Div. of Physical Chemistry. S-100 44 Stockholm 70, Sweden. 47 pp.

1802 Wettermark, G. (ed).

1980 Thermochemical Energy Storage: Proceedings from the International Seminar on Thermochemical Energy Storage, Stockholm, January 7-9.

Swedish Council for Building Research, Stockholm, Sweden. 434 pp. PB81-114324.

1870 Whike, A.S.

1979 Energy Conservation and Pollution Control: Two Advantages of Coil Coating. Americal Chemical Society. 1653-1655. Paper no. 799343.

$1360 z$ Whitaker, R.B., G.H. Jenkins, G.L. Ball and I.0. Salyer.

1979 Energy storage for solar air conditioning applications utilizing a form-stable, high density polyethylene pellet bed. Proceedings of Solar Energy Storage Options, San Antonio, TX, March 19-20. 1:581-592. CONF-790328-P2.

545 White, D.E. and D.L. Williams (eds).

1975 Assessment of Geothermal Resources of the United States - 1975. U.S. Geological Survey, Arlington. $155 \mathrm{pp}$. Circular 726.

1372 White, R.E. and W.C. Blackburn.

1969 Evolution of a field operating organization: a case study. pp. 236-242 in Drilling Production and Practice, American Petroleum Institute.

1544 aa White, S.H., U.M. Twardoch and M.M. Bower.

1980 Molten nitrate salt chemistry studies. Proceedings of the DOE Thermal and Chemical Storage Annual Contractors' Review Meeting. 101-104.

1264 Whitehead, W.R. and E.J. Langhetee.

1978 Use of bounding wells to counteract the effects of preexisting groundwater movement.

Water Resources Research 14(2):273-280.

523 Wickersham, G.

1977 Review of C.E. Jacob's Doublet Well.

Groundwater 15(5):344-347.

949 Wilder Construction Co., Inc.

1979 A Total Development Contractor: Site Preparation to Waste Disposal. Wilder Construction Co., Inc, Bellingham, WA. 
1863 Wiles, L.E.

1979 Analysis of Mass Cycling in Porous Rock Reservoirs for Compressed Air Energy Storage.

American Chemical Society. 441-445. Paper no. 799092.

524 Willhite, G.P.

1967 Over-all heat transfer coefficients in steam and hot water injection wells. Journal of Petroleum Technology 19:607-615.

526 Willhite, G.P., J. Wagner, F. Simonpietri and J. Stocker.

1974 Disposal of Heated Water Through Ground Water Systems: Vol. 1, Technical and Economic Feasibility.

Kansas Water Resources Research Institute, Lawrence, Kansas. 144 pp. PB-236-303.

527 Willhite, G.P. and J. Wagner.

1974 Disposal of Heated Water Through Ground Water Systems: Vol. 2, User's Manual.

Kansas Water Resources Research Institute, Lawrence, Kansas. PB-236-302.

525 Willhite, G.P. and W.K. Dietrich.

1966 Design criteria for completion of steam injection wells. pp. 62-69 in Thermal Recovery Techniques, Society of Petroleum Engineers of AIME, Dallas.

544 Williams, D.A. and J.B. Tiedemann.

1974 Heat pump powered by natural thermal gradients. 9 th Conference Intersociety Energy Conservation of Engineers, ASME Paper 749041. 538-549.

1648 Williams, G.T., C.R. Attwater and F.C. Hooper.

1979 A Design method to determine the optimal distribution and amount of insulation for in-ground heat storage tanks. International Solar Energy Society Silver Jubilee Congress, At 1 anta, GA, May. DOE-CS-32939-7.

1816 Williams, 0.M. and P.0. Carden.

1979 Ammonia dissociation for solar thermal absorbers. Energy Research 3:129-142.

1979 Energy storage efficiency for the ammonia/hydrogen-nitrogen thermochemical energy transfer system. Energy Research 3:29-40.

1411 Williams, R.E.

1978 Well penetration and stimulation. Geothermal Resources Counci1, Transactions 2:729-730. 
948 Williams, T.E.

1978 The Use of Bounding Wells to Counteract the Effect of Gravity in Dipping Aquifers.

M.S. Thesis, Louisiana State University. $84 \mathrm{pp}$.

1064 Will ingham, R.C.

1974 Conserving fuel in the drop forging industry. Metallurgia and Metal Forming 41(2):47-48.

528 Willman, B.T., V.V. Valleroy, G.W. Runberg, A.J. Cornelius, and L.W. Powers.

1961 Laboratory studies of oil recovery by steam injection. Journal of Petroleum Technology 222:681-690.

950 Wilson, $\mathrm{K}$.

1978 Enhanced-recovery inert gas processes compared. $0 i 1$ and Gas Journal 76(31):162-164.

1608 Wilson, M.R.

1980 Feasibility study for a large thermal storage and heat pumping installation. Applied Energy 6(3):159-169.

11771 Wilt, M.J. and N.E. Goldstein.

1978 Resistivity studies at Cerro Prieto. pp. 37-40 in Earth Sciences Division Annual Report, Lawrence Berkeley Laboratory, Berkeley, CA. LBL-8648.

763 Wingquist, C.F.

1976 Elastic Moduli of Rock at Elevated Temperatures. U.S. Department of the Interior and Bureau of Mines. 18 pp. RI 7269.

1684 Winslow, A.G. and L.A. Wood.

1959 Relation of 1 and subsidence to ground-water withdrawals in the Upper Gulf Coast Region, Texas. Mining Engineering 11:1031-1034.

529 Winslow, A.G. and W.W. Doyel.

1954 Land-surface subsidence and its relation to the withdrawal of groundwater in the Houston-Galveston Region, Texas . Economic Geology 49:413-422.

952 Wintz, W.A., R.G. Kazmann, and C.G. Smith, Jr.

1970 Subsidence and Ground Water Offtake in the Baton Rouge Area. Louisiana State Universtiy, Louisiana Water Resources Research Institute. $70 \mathrm{pp}$. Bulletin G.

9999dw Wisconsin State Energy Office.

1979 District Heating and Cooling Systems for Communities Through Power Plant Retrofit and Distribution Network: Phase 1-Final Report. Wisconsin State Energy Office, Madison. 192 pp. Vol 2. C00-4981-1. 
530 Witherspoon, P.A., H.A. Espinosa, M.J. Lippmann, A.M. Mercado and H.A. Wollenberg.

1978 Mexican-American Cooperative Program at the Cerro Prieto Geothermal Field.

Lawrence Berkeley Lab, Earth Sci.Div. and Comision Federal de

Electricidad, Coor. Ejecutiva de Cerro Prieto. 33 pp. LBL-7095.

876 Witherspoon, P.A., I. Javande 1, S.P. Neuman, and R.A. Freeze.

1967 Interpretation of Aquifer Gas Storage Conditions from Water Pumping Tests.

American Gas Association, New York. 273 pp.

1387 Witherspoon, P.A., J.S.Y. Wang, K. Iwai and J.E. Gale.

1979 Validity of Cubic Law for Fluid Flow in a Deformable Rock

Fracture.

Univ. of CA, Dept. of Materials Science and Mineral Engineering, and Lawrence Berkeley Lab, Berkeley, CA. 28 pp. LBL-9557.

531 Witherspoon, P.A. and J.A. Apps.

1977 Fundamental Geosciences Program: Annual Report 1977.

Lawrence Berkeley Laboratory, Earth Sciences Division, Berkeley, CA. 35 pp. LBL -7058 .

533 Witherspoon, P.A. and 0. Degerman.

1978 Swedish-American Cooperative Program on Radioactive Waste Storage in Mined Caverns: Program Summary.

Swedish Nuclear Fuel Supply Co., Stockholm and Lawrence Berkeley Laboratory, Earth Sciences Div., Berkeley. 26 pp. LBL-7049.

1315r Wittenberg, L.J. and M.J. Harris.

1979 Evaluation of a large nonconvective solar pond.

Proceedings of Solar Energy Storage Options, San Antonio, TX.

March 19-20. 1:193-202. CONF-790328-P1.

1790 Wittenburg, L.J. and M.J. Harris.

1980 Miamisburg Salt-Gradient Solar Pond: Mid-1980 Status Report.

Mound Facility, Miamisburg, OH. 22 pp. MLM-2739(OP).

532 Wollenberg, H.A., R.E. Bowen, H.R. Bowman, and B. Strisower.

1979 Geochemical Studies of Rocks, Water, and Gases at Mt. Hood, Oregon.

Lawrence Berkeley Laboratory, Earth Sciences Division, Berkeley, CA. 57 pp. LBL-7092.

9999ca Wood, W.W.

1979 Development of technical site criteria for artificial recharge. Wastewater Reuse for Groundwater Recharge Symposium, Pomana, Sept $6-7$.

1976 Guidelines for collection and field analys is of ground-water samples for selected unstable constituents. 
U.S. Geologicial Survey, Arlington. Techniques of Water Resources Investigations, Book 1, Chapter D1.

534 Wooding, R.A.

1957 Steady state free thermal convection of liquid in a saturated permeable medium.

Journal of Fluid Mechanics 2:273-285.

535

1960 Rayleigh instability of a thermal boundary layer in flow through a porous medium. Journal of Fluid Mechanics 9:183-192.

1962 Free convection of fluid in a vertical tube filled with porous material. Journal of Fluid Mechanics 13:129-144.

537

1964 Mixing-layer flows in a saturated porous medium. Journal of Fluid Mechanics 19:103-113.

621

1958 An experiment on free thermal convection of water in saturated permeable material. Journal of Fluid Mechanics 3:582-600.

538 Wooding, R.A. and H.J. Morel-Seytoux.

1976 Multiphase fluid flow through porous media. 8:233-274 in Van Dyke, Vincenti, and Wehausen, eds, Annual Review of Fluid Mechanics, Annual Reviews, Inc. Palo Alto, CA. V.8.

1682 Woodside, W. and J.B. Cliffe.

1958 Heat and moisture transfer in closed systems of two granular materials.

National Research Council, Canada. 8 pp.

1544p Wright, J.D.

1980 Direct contact heat transfer for thermal energy storage. Proceedings of the DOE Thermal and Chemical Storage Annual Contractors' Review Meeting. 60-63.

1901 Wyatt, D.D.

1981 Advanced energy storage systems. Technical and Economic Analys is Meeting, Chicago, April 22.

539 Wyllie, M.R.J. and M.B. Spangler.

1952 Application of electrical resistivity measurements to problem of fluid flow in porous media.

Bulletin of American Association of Petroleum Geologists $36(2): 359-403$. 
1446 Wyman, C.E., R.J. Copeland, J.D. Wright and F. Baylin.

1980 Solar Energy Storage Program: FY79 Annual Report.

Solar Energy Research Institute, Golden, C0. 15 pp.

SERI/PR-631-632.

15440 Wyman, C.E.

1980 An Overview of the SERI solar energy storage program.

Proceedings of the DOE Thermal and Chemical Storage Annual

Contractors' Review Meeting. 56-58.

540 Yanagase, T., Y. Suginohara, and K. Yanagase.

1970 The Properties of scales and methods to prevent them.

U.S. Symposium on the Development and Utilization of Geothermal Resources, in Geothermics. 2(2):1619-1623.

1315s Yang, K.T. and M. Delich.

1979 The Application of thermosyphon in a long-duration low temperature storage system for residential cooling.

Proceedings of Solar Energy Storage Options, San Antonio, TX. March 19-20. 1:203-210. CONF-790328-P1.

1066 Yee, W.C.

1974 Thermal aquaculture: potential and problems. pp. 139-149 in Energy Production and Thermal Effects, Limnetics, Inc.

1627 Yeh, G.T.

1980 Interstitial Water Transport Model in Aquifer Systems by Finite Element Method.

Oak Ridge National Laboratory, Oak Ridge, TN. 15 pp. CONF-8005101-1.

1826 Yeh, L.T. and B.T.F. Chung.

1976 Transient Heat Conduction in a Finite Medium with Phase Change. The American Society of Mechanical Engineers, New York. 8 pp. 76-WA/HT-3.

$1453 \mathrm{~m}$ Yeoman, J.C.

1979 A Net energy analysis of a cogeneration-district heating system and two conventional alternatives. Official Proceedings, 70th Annual Conference of the International District Heating Assn. June 18-20. Section 18.

764 Young, K.L.

1967 Effect of assumptions used to calculate bottom-hole pressures in gas wells. Journal of Petroleum Technology 19:547-550.

1827 Yuan, S.W.

1979 Solar Energy Storage and Utilization. U.S. Patent \# 4,138,995. 
541 Yuan, S.W., A.M. Bloom, and M. Nazli.

1976 Long duration earth storage of solar energy.

Solar Cooling and Heating: A National Forum, Proceedings, Dec.

13-15, Miami Beach. pp. 33-39. CONF-761220.

543

1977 Heat Transfer in Solar Energy Storage.

American Society of Mechanical Engineers, New York. 10 pp.

$77-\mathrm{HT}-38$.

765 Yuan, S.W. and L.S. Galowin.

1976 A Central solar energy utilization system.

International Seminar Future Engineers Prod. Heat and Mass

Transfer Problems. 1:139-148.

1112 Yudow, B.D., N.R. Baker, R.R. Tison, and P.F. Swenson.

1979 Feasibility of a Heat-Actuated Heat-Pump-Centered Integrated Community Energy System.

American Chemical Society, Washington, D.C. 799358, 1687-1692.

1224 Zenone, C. and G.S. Anderson.

1978 Summary Appraisals of the Nation's Ground-Water Resources:

Alaska.

U.S. Geological Survey, Arlington. 28 pp. Professional Paper

813-P.

$1544 \mathrm{ag}$ Zimmerman, W.F., L.E. Stacy and G.C. Wesling.

1980 Storage requirements definition and SRE design for dish Stirling systems.

Proceedings of the DOE Thermal and Chemical Storage Annual

Contractors' Review Meeting. 130-134.

542 Zoback, M.D. and J.S. Byerlee.

1976 Effect of high-pressure deformation on permeability of Ottawa

Sand.

American Association of Petroleum Geologists Bulletin $60(9): 1531-1542$.

1386 Zohdy, A.A.R., G.P. Eaton, and D.R. Mabey.

1974 Techniques of Water-Resources Investigations of the U.S. Geological Survey: Chapter D1-Application of surface geophysics to ground-water investigations.

U.S. Geological Survey, Arlington. 116p.

1320 Zuck, J.C.

1979 Aquifer Thermal Energy Storage: Environmental Laws and Regulations.

Pacific Northwest Laboratory, Battelle, Richland, WA. 26 pp. (Draft).

1225 Zurawski, A.

1978 Summary Appraisals of the Nation's Ground-Water Resources:

Tennessee Region.

U.S. Geological Survey, Arlington. $35 \mathrm{pp}$. Professional Paper 813-L. 
AUTHOR INDEX 
ACEC Research and Management 1710 Foundation

Aase, D.T.

Abbatiel1o, L.A. $\quad 1667$

Abdel-Wahed, R.M. 1547

Abrams, A. 1

Achenbach, P.R. $\quad 296$

Ackerman, T.V. $\quad 2$

Acosta-Gonzalez, G. $\quad 1657$

Acurex Corporation, Aerotherm 1116

Division

Adachi, T. 631

Adams, D.D. $\quad 972$

Adams, M.V. $\quad 1340$

Adams, R.H. 3

Adkison, J.A. $\quad 787$

Adolfson, W.F. $\quad 975$

Advani, S.H. 632

Advisory Council on Historic 788

Preservation

Aerospace Corp., Environment $\quad 1345$

and Conservation

Directorate

Aeschliman, D.P. $\quad 836$

Aguado, E. $\quad 1756$

Ahlgren, W.L. $\quad 1072$

Aiken, G.R. $\quad 9999 \mathrm{cw}$

Air Conditioning, Heating and 1336

Refrigeration News

Air Conditioning, Heating and 176

Aktan, T.

633

$\begin{array}{lr}\text { Al-Ansari, J.M. } & 1734 \\ \text { Al-Rikabi, H.M. } & 802\end{array}$

Alario, J.

Alavian, $V$.

$1544 \mathrm{t} 1383 \mathrm{al}$

Albertson, M.L. $\quad 404$

Alexander, F. $\quad 1067$

Allegrini, G. 5

Allen, C.P. 1835

Allen, D.M. $\quad 1906$

Allen, L. $\quad 1537$

Allen, R. $\quad 1158$

Allen, R.D. $\quad 620$

Aller, P. 1068

Allison, L.E. $\quad 6$

Allman, D.W. $\quad 1496$

Alpert, J.E. 7

Altman, R.G. $\quad 473$

Altschuler, S.J. 1641

Alverson, R.M. 181

Alzheimer, D.P. $\quad 1125$

Amaro, J. 293

973

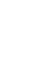


Ambrose, E.R.

American Chemical Society

89

American Gas Association,

Committee on Underground

Storage

American Geological Institute 1343

American Institute of

1482

$1483 \quad 1484$

Aeronautics and

Astronautics

American Nuclear Society

1439

American Petroleum Institute

American Petroleum Institute,

109

Environmental Affairs

Department

American Society of Heating, Refrigerating, and

Air-Conditioning Engineers

Anand, R.

789

1714

Anand, R.K.

Ananth, K.P.

Andersen, P.F.

Anderson, C.A.

Anderson, C.J.

Anderson, E.J.

Anderson, G.S.

Anderson, J.H.

Anderson, $\mathrm{K}$.

Anderson, M.P.

Anderson, P.A.

Anderson, S.H.

Andrews, B.

Andrews, C.B.

Angerman, T.W.

Ansari, J.M.

Anuskiewicz, T.

$\begin{array}{llll}636 & 637 & 638 & 703\end{array}$

Aparisi, R.R.

Apley, W.J.

Appel, C.A.

Apps, J.A.

Aquilian, C.

Archie, G.E.

Argonne National Laboratory,

Oak Ridge National

Laboratory and Trinity

University

Arihara, N.

1664

1015

$1383 \mathrm{e} 1482 \mathrm{cw}$

626

1804

1282

777

1224

11

12

14

976

$1544 \mathrm{k}$

21

13

1401

851

1633

243

267

17

80

93

242

1315

1758

1307

1312

$13591383 \mathrm{av}$

$15 \quad 1750$

$14 \quad 15,601$

Armstrong, T.B.

Arnow, T.

Aronofsky, J.S.

Arosio, S.

Aruna, M.

Asahina, $M$.

Asbury, J.G.

531 1177as

$1360 \quad 1361$ 
Ash, S.R.

1162

Asmussen, L.E.

Asselman, G.A.A.

Attwater, C.R.

Atwood, J.E.

Auer, W.W.

Ausseur, J.Y.

Aust in, A.L.

Avdonin, N.A.

Avery, P.A.

Axtmann, R.C.

Aydelotte, S.R.

Ayerbe, $A$.

Ayres, B.L.

Ayyaswamy, $S$.

Aziz, K.

B\&A Engineers, LTD

Babcock, W.H.

Bachmat, Y.

Bahadur, $S$.

Baier, D.C.

Bailey, J.A.

Bailey, R.G.

Bailey, W.J.

Bajura, R.A.

Bak, D.J.

Baker, B.A.

Baker, E.T., Jr.

Baker, M.A.

Baker, N.R.

Baker, P.E.

Bakhmeteff, B.A.

Balashov, L.S.

Balke, K.D.

Ball, G.L.

Bamberg, S.A.

Banik, G.J.

Banks, H.O.

Bannerot, R.

Barbera, N.J.

Barbish, A.B.

Barkman, J.H.

Barnes, B.A.

Barnes, P.R.

Barnes, W.A.

Bartel, J.J.

Barth, M.G.

Bartholomew, C.H.

Basak, P.

Bass-Becking, L.G.M.

Bathelt, A.G.

Bathen, K.H.

Battelle Columbus
1448

1118

357

1094

20

734

255

21

1356

240

639

640

1368

1824

979

97

1161

1910

1112

1707

22

23

$24 \quad 520$

1833

756

$1582 \mathrm{~m}$

25

1193

1004

641

382

26

1715

1129

1894

1441

1465

331

642

1831

259

1156 $\begin{array}{lll}954 & 955 & 1648\end{array}$

635

1758

1294

$18711360 \mathrm{z}$

$1582 n$ 


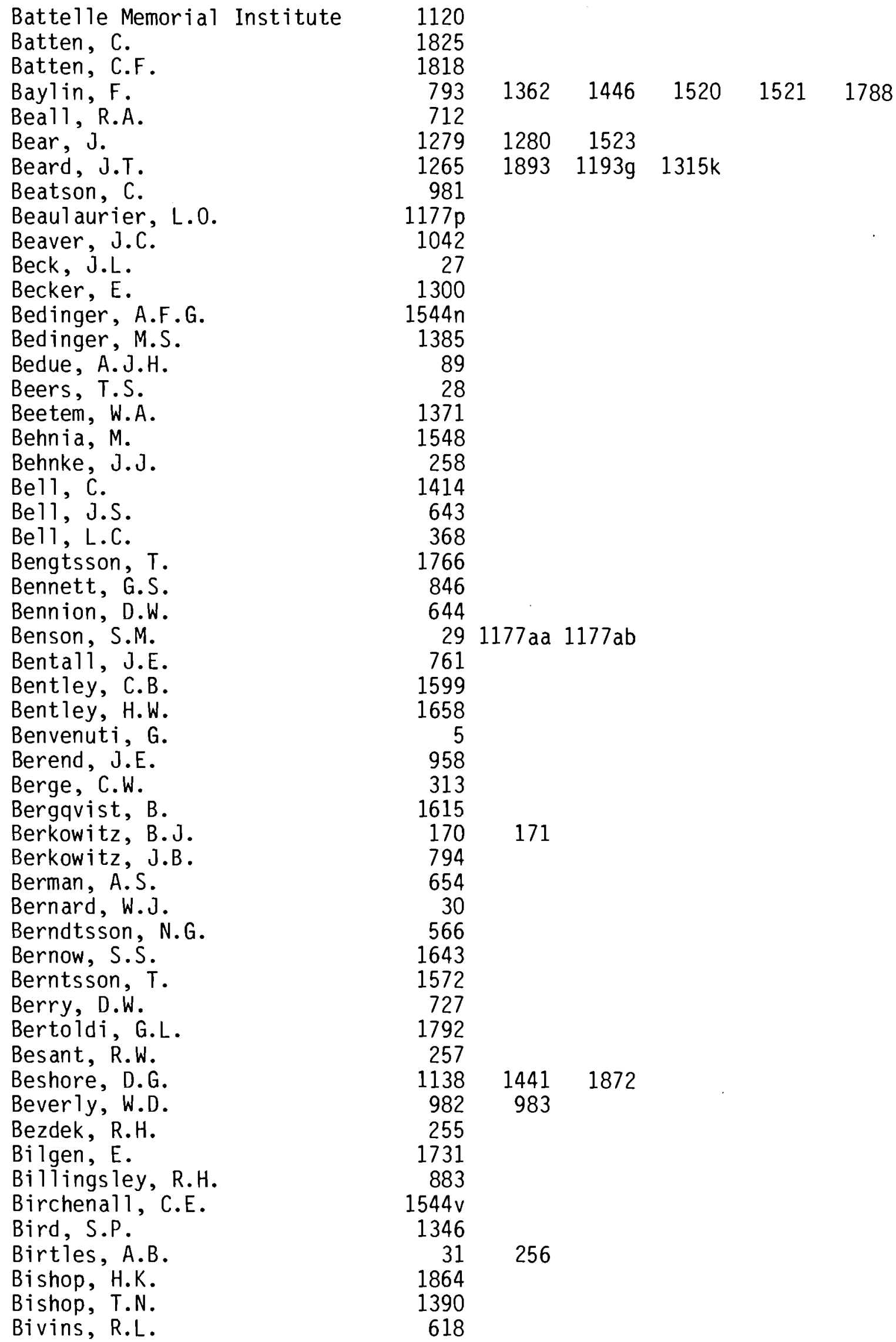


Bjerklie, J.W. 984

Bjornsson, A. 44

Black and Veatch Consulting 1634 Engineers

Black, R.A.

BTackburn, W.C.

B lackshear, P.L.

Blackwel1, D.D.

Blahnik, D.E.

Blair, C.K.

Blake, T.R.

Blakeley, L.E.

Blank, Z.

Blatz, E.H.

Bleakley, W.B.

Blecher, W.A.

Blevins, T.R.

Bligh, T.P.

Block, D.A.

Blomquist, C.A.

Bloom, A.M.

Bloomfield, N.J.

Bloomster, C.H.

Bloss, S.

Bloyd, R.M., Jr.

Boberg, T.C.

Boche, R.E.

Bodvarsson, $G$.

Bodvarsson, G.S.

Boehm, D.W.

Boehm, R.

Boeing Engineering and Construction

Boersma, L.

Boldizsar, T.

Bolton, P.

Boneau, D.F.

Bonisteel, W.D.

Bonne, U.

Bonnet, C.W.

Borghi, L.C.

Bories, S.A.

Borst, W.L.

Bosazza, V.L.

Bose, J.E.

Boser, 0.

Bostock, C.A.

Boswe 1 1, E.H.

Botham, R.A.
$1482 x$

1372

762

650

$16071582 r$

$1582 n$

32

34

1093

1162

1377

$1582 v$

883

1611

1887

$1440 \quad 1879$

$541 \quad 543$

106

$\begin{array}{llll}35 & 195 & 341 & 1524\end{array}$

254

1163

645

1069

36

42

247

443

1165

1256

1717

553

1193

1113

$602 \quad 880$

46

47

870

985

1037

120

1004

20

1477

48

1315t 9999eb

1832

49

1173

$1833 \quad 1871$

1547

1164

$628 \quad 1706$

$\begin{array}{rrrrr}37 & 38 & 39 & 40 & 41 \\ 43 & 44 & 45 & 245 & 246 \\ 248 & 249 & 250 & 251 & 253 \\ 646 & 647 & 648 & 649 & 884 \\ 1166 & 1167 & 1168 & 1169 & 1170 \\ 1257 & 9999 \mathrm{r} & & & \\ 11772 & 1177 \text { af } & 1177 \text { ag } & & \end{array}$


Bourdeau, L.E. Bourne, J.G. Bouwer, $H$. Bowen, R.E. Bowen, R.G. Bower, M.M. Bowman, $\mathrm{H}$.

Bowman, H.R. Bowman, R.W. Bowser, M.L. Brace, W.F. Bradley, D.J. Bradley, S.P. Bramlette, T.T. Brandshaug, $T$. Brashear, J.P. Brashears, M.L. Bratrud, T.F. Braunlich, F.H. Braunstein, J. Bray, J.A. Bredehoeft, $J$. Bredehoeft, J.D. Breitenbach, E.A. Brett, C.E.

Bricarello, J.R. Briggs, J.B. Briggs, J.E. Briggs, L.I., Jr. Briley, G.C.
1758

1780

1864

55

653

266

986

1223

1892

885

1612

1253

1768

1172

9999dj 9999dk

$1036 \quad 1866$

$1008 \quad 1147$

$797 \quad 886$

1302

800

$56 \quad 233$

$57 \quad 897$

966

$1482 u$

1866

887

264

265 
Brunger, A.P.

Brunton, G.D.

Brutsaert, W.

1705

Bryan, W.L.

1709

Bryant, C.T.

Brzezinski, A.

1304

881

1218

Building Research and

Practice

Bull, W.B.

Bullen, R.S.

Bundy, F.P.

987

Bureau of National Affairs, Inc

Buretta, R.J.

Burggraf, $F$.

Burke, D.B.

Burlingame, M.V.

Burns, P.

Burolla, V.P.

Burt, R.A.

Buscheck, T.

Buscheck, T.E.

Business Publishers

619

Business Publishers, Inc

Busk, R.S.

Busse, F.H.

Butler, W.S.

Byerlee, J.S.

654

106

494

655

13151

1894

888

$16021177 a 1$

9999du

1513

900

3.129

1430

466

542

Cagle, D.B.

Cahn, R.P.

1884

1099

Calamai, A.

1550

Caldwe 1 1, R.T.

1834

California, (St), Dept of Water Res and Univ of CA, Dept of Civil Eng and Geotech Eng

California, State of 1652

Callan, D.M. $\quad 1778$

Calm, J.M.

262

1905

Calvert, E.D.

Cambel, A.B.

Came 1i, G.M.

712

1565

1394

Campbe 1, D.

Campbe 11, D.A.

Campbe 11, M.D.

Canada Mortgage and Housing Corp.

Canada Mortgage and Housing Corporation, Research and Development Division

Canada Mortgage and Housing Corporation, Technical 
Research Division

Capuano, L.E., Jr.

666

Carabel1i, E.

1394

Carciello, N.

293

Carden, P.0.

Carey, D.A.

1816

Carling, R.W.

Carlson, D.K.

Carlson, F.M.

Carlson, R.C.

Carlsson, B.

1133

$1544 z$

1544 ap

799

1351

1650

Carnegie, E.J.

1069

Carpenter, D.H.

889

Carr, J.H.

1121

Carro 11, H.B.

Caruso, J.V.

Carve11, K.L.

561

772

Carver, J.A.

Casamajor, A.B.

61

Casazza, J.A.

890

261

Casse, F.J.

Casse 1, D.E.

Castinel, G.

Castleton, R.N.

Catton, I.

Caudle, B.H.

Cavalleri, G.

Cayais, J.L.

518

1201

781

1284

$1193 k$

693

260

939

Cazal, A.

63

Cease, M.E.

Cederstrom, D.J.

$1482 \mathrm{cx}$

Centrilift, Inc

1173

780

Cernoch, S.

988

Ceron, $P$.

Cerruti, D.

Cha, B.K.

1550

1653

1680

Chakravorty, S.K. $\quad 800$

Chalmers, J.A. $\quad 777$

Chan, Y.K.

Chaney, S.

Chang, G.C.

Chang, H.L.

Chang, H.Y.

Chapman, H.L.

Chappelear, J.E.

Charbeneau, R.J.

Charroppin, $P$.

438

1544 ae

553

801

$\begin{array}{rr}294 & \\ 1817 & 1819\end{array}$

Chase, C.A.

632

1070

64

1588

891

1426

1338

Chase, E.B.

$\begin{array}{lr}\text { Chasteen, A.J. } & 1400 \\ \text { Chatas, A.T. } & 667\end{array}$

Chaturvedi, S. $\quad 1319$

Chaw, S.Y.

218

1071

802

Chemical Week 


\begin{tabular}{|c|c|c|c|c|c|c|}
\hline Chen, C.S. & 1654 & & & & & \\
\hline Chen, E. & 547 & 1825 & & & & \\
\hline Chen, E.C.M. & 1818 & & & & & \\
\hline Chene, C. & 1655 & & & & & \\
\hline Cheney, J.A. & 1551 & & & & & \\
\hline Cheng, $P$. & 724 & & & & & \\
\hline Chepurniy, $N$. & 1105 & & & & & \\
\hline Chern, W.S. & 1245 & & & & & \\
\hline Cherne, J. & 989 & $1582 \mathrm{~b}$ & & & & \\
\hline Cherry, W.R. & 978 & & & & & \\
\hline Chevalley, B. & 1810 & & & & & \\
\hline Chewning, R.C. & 289 & 290 & 291 & & & \\
\hline Childs, S.W. & 1522 & & & & & \\
\hline China, People's Republic of & 1585 & & & & & \\
\hline Chiu, H.H. & 739 & & & & & \\
\hline Chiu, W.S. & 1045 & & & & & \\
\hline Chow, V. & 65 & 66 & & & & \\
\hline Christensen, J. & 990 & & & & & \\
\hline Christensen, J.J. & 1465 & & & & & \\
\hline Christenson, J.A. & 1144 & & & & & \\
\hline Christian, J.E. & 1720 & & & & & \\
\hline Christianson, A.G. & 1082 & & & & & \\
\hline Chubb, T.A. & 991 & 9999dc & $1544 u$ & & & \\
\hline Chung, B.T.F. & 1826 & & & & & \\
\hline Churchill, D.J. & 603 & & & & & \\
\hline Cigni, U. & 1375 & 1376 & & & & \\
\hline City of Piqua, Ohio, & $9999 d x$ & & & & & \\
\hline Claar, T.D. & 1845 & $1544 \mathrm{~s}$ & & & & \\
\hline Claesson, $\mathrm{J}$ & $\begin{array}{l}1184 \\
1744\end{array}$ & $\begin{array}{l}1584 \\
1749\end{array}$ & $\begin{array}{l}1619 \\
1765\end{array}$ & $\begin{array}{l}1620 \\
1766\end{array}$ & $\begin{array}{l}1622 \\
1767\end{array}$ & 1649 \\
\hline Clark, A.F. & 87 & 270 & 1072 & & & \\
\hline Clark, E.C. & $1193 \mathrm{~h}$ & $1544 a p$ & & & & \\
\hline Clark, G. & 1835 & $1360 a$ & $1360 b$ & & & \\
\hline Clark, J.B. & $\begin{array}{r}668 \\
1129\end{array}$ & & & & & \\
\hline Clark, W.W. & 67 & & & & & \\
\hline Clarke, J. & $1177 \mathrm{~m}$ & & & & & \\
\hline Cliff, W.C. & 267 & & & & & \\
\hline Cliffe, J.B. & 1682 & & & & & \\
\hline Clinch, $M$. & 1544 as & & & & & \\
\hline Close, D.J. & 1073 & 1074 & 1075 & 1076 & & \\
\hline Cluff, C.B. & $1785 a p$ & & & & & \\
\hline Coats, K.H. & 669 & & & & & \\
\hline Cochrane, R.L. & $1544 m$ & $1482 \mathrm{ao}$ & & & & \\
\hline Coffay, B. & 1046 & & & & & \\
\hline Cohen, G. & 992 & & & & & \\
\hline Cole, $\mathrm{H}$. & 1908 & & & & & \\
\hline Cole, M.H. & 68 & & & & & \\
\hline Coleman, W.R. & 1549 & & & & & \\
\hline Coles, B.L. & 1283 & & & & & \\
\hline Collie, M.J. & 803 & 804 & & & & \\
\hline Collins, A.G. & 69 & 70 & 71 & 72 & 73 & \\
\hline Collins, R.E. & 74 & 75 & 151 & 1198 & 1697 & $1383 p$ \\
\hline Colsher, C.S. & 1334 & & & & & \\
\hline
\end{tabular}


Combarnous, M.A.

Committee on Natural

Resources

Conley, F.R.

Connor, D.W.

Consultant Review Team

Cook, C.

Cook, G.E.

Cook, J.D.

Cook, R.J.D.

Cook, T.D.

Cooke, R.S.

Cooke, W.L.

Cooley, C.H.

Cooley, R.L.

Cooper, H.H.

Cooper, L.Y.

Cooper, V.R.

Copeland, R.J.

Corapcioglu, M.Y.

Corbett, G.E.

Cormary, Y.

Cornelius, A.J.

Cortel1, B.

Corwin, R.F.

Cosner, S.R.

Coste110, V.A.

Cottingham, J.G.

Couch, R.W.

Coulbois, P.

Coutant, C.C.

Cowen, D.S.

Cox, D.

Cox, D.K.

Cox, J.E.

Cox, R.J.

Cox, W.E.

Craig, R.A.

Crampton, $H$.

Crane, R.E.

Crawford, M.

Creer, J.M.

Crichlow, H.B.

Cropsey, M.G.

Crosby, G.W.

Crow, N.B.

Crowley, B.k.

Cruz, I.P.

Cturtnicek, T.E.

Cuellar, G.

Culver, G.G.

Cummings, R.G.

Cunningham, A.B. $\begin{array}{lll}20 & 628 & 781\end{array}$

76

901

$\begin{array}{llll}561 & 805 & 806 & 1680\end{array}$

$1468 \quad 1793$

1825

371

1362

955

819

842

1704

$1582 \mathrm{~m} \quad 1582 \mathrm{n}$

$269 \quad 597$

77

670

$9999 a$

1446

1705

1818

78

528

79

$1177 k$

80

$1193 \mathrm{i}$

1721

884

81

577

1883

893

1229

671

100

614

553

1476

1289

268

267

$82 \quad 918$

1077

313

1309

696

510

1122

$83 \quad 105 \quad 433$

$\begin{array}{llllll}84 & 85 & 326 & 327 & 604 & 807\end{array}$

$\begin{array}{lll}1486 & 1543 \quad 1544 q\end{array}$

1229

773 
Curran, H.M.

Currie, J.W.

Curry, D.M.

Curtner, K.L.

Cushing, E.M.

Czech, J.

D'Hooge, J.A.

Dahlgren, $T$.

Daly, C.J.

Daniels, D.G.

Daniels, E.J.

Danielson, H.H.

Darby, D.A.

Davey, J.V.

Davidson, E.

Davidson, E.S.

Davidson, J.E.

Davidson, J.H.

Davies, J.B.

Davis, A.A.

Davis, A.H.

Davis, D.C.

Davis, E.G.

Davis, G.H.

Davis, H.A.

Davis, K.E.

Davis, L.R.

Davis, S.N.

Davison, J.E.

Davison, R.R.

Davitian, H.

Day, J.A.

Dayan, J.

DeCagna, A.

DeCicco, S.G.

de Digiacomo, A.C.

DeGraff, J.

DeLancey, G.B.

DeMarsily, G.

DeRenzo, D.J.

DeVan, J.H.

Dewalle, D.R.

Dean, T.S.

Deans, H.A.

Defferding, L.J.

Degerman, 0 .

Delaney, J.M.

Delclaud, J.P.

Delich, $M$.

Dellinger, T.B.

Denouden, $C$.

Den is, L.H.D.

Denison, E.B.
$1315 i$

1346

671

1145

1213

1102

1781

1873

1755

1078

1883

894

972

$1177 t$

673

1504

$14131544 f$

$1544 \mathrm{C}$

889

1022

230

993

672

273

1022

74

1703

602

1658

1413

86

1679

87

1815

1011

776

1789

1228

1896

78

808

$1544 a b$

$416 \quad 418$

$\begin{array}{lllll}75 & 151 & 1681 & 1697 & 1702\end{array}$

$1691 \quad 1701$

$1544 f$

1266 9999ec 1383au

1123

1273

1624

533

1460

674

$1315 \mathrm{~s}$

88

1807

90
880

$270 \quad 1072$

272

973

95

675 


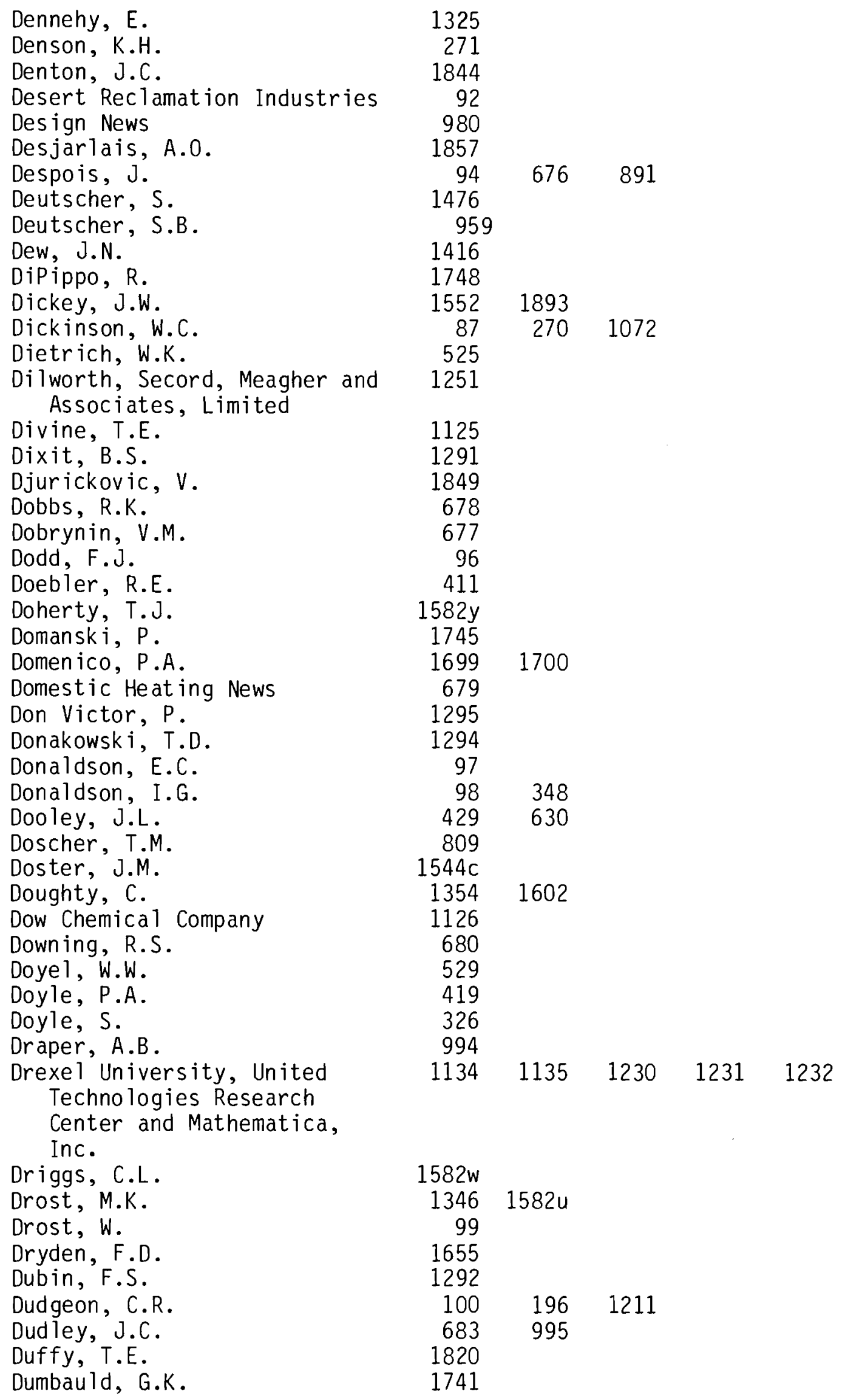


Duncan, S.S.

Dunham, G.F.

$9999 \mathrm{df}$

Dunkle, R.V.

1806

1075

Dunlap, W.J.

344

1300

996

1079

Duscha, R.A.

Duva 11, G.D.

1533

Dvoracek, M.J

101

Dvorov, I.M.

Dwyer, P.R.

Dybbs, A.

$1454 k$

681

448

Dyer, K.L.

Eakin, T.E.

Earlougher, R.C.

1175

810

Easton, C.R.

1846

Eaton, G.P.

1386

Eatough, D.

1465

Ebeling, $L$.

Ebeling, L.L.

Eberle, M.

999ec

102

1364

Eckert, A.W.

103

Edde, $H$.

Edens, M.H.

Edesess, $M$.

Edie, D.D.

Edin, R.E.

Edward E. Johnson, Inc

$544 a j$

1592

1311

1732

$1193 i$

332

$1360 m$ 1383an

Edwards, A.L.

Edwards, D.T.

Edwards, J.A.

Edwards, J.H.

Eftring, B.

Eggers, D.E.

Ehriich, R.

Ehrliech, G.G.

Eibling, J.A.

Eilers, L.H.

Einarsson, S.S.

Eisenstadt, R.

Eissenberg, D.M.

Ekroth, I.A.

El-Hadidi, S.

Elder, W.J.

Electric Information

Publications

Electric Power Research Institute

104

1899

$1544 \mathrm{C}$

682

1584

605

846

1536

1013

1782

105

154

798

998

463

1428

907

1767

744

1131 ectric Power Research

1357

$811 \quad 1178 \quad 1306$

Institute, The EPRI

Planning Staff

Electrical World

1429

1553

Eliason, J.R.

1769

Elkan, G.H.

Elkins, L.F. 
Ellenberger, F.R. $\quad 106$

Elliott, J.F. $\quad 999$

Elliott, R.C. 1909

Ellis, A.J. . $\quad 1646$

Ellis, R.C. $\quad 479$

Elmer, D.B. 1451

Emanuel, A.S. $\quad 887$

Emerson, P.F. $\quad 1547$

Emerson, P.L. $\quad 762$

Endsin, $N$.

Energy Systems, Inc

Energy User News

Engelke, C.E.

Engen, I.A.

Engle, W.W.

Enns, M.K.

Erdmann, D.E.

Erickson, G.M.

Erikson, R.L.

Ervin, $G$.

Esbensen, T.V.

Eslinger, D.H.

Esmail, 0.J.

Espinosa, H.A.

Esterka, F.

Evans, A.R.

Fabbri, F.

Fafarman, L.M.

Fanchi, J.R.

Fang, L.R.

Farouq-Ali, S.M.

Farris, G.F.

Fassbender, L.L.

Fauconnier, J.C.

Faust, C.R.

Federal Register

Fellows, S.K.

Felsenthal, $M$.

Fenn, C.D.

Fenske, P.R.

Feodoroff, N.V.

Ferarra, A.

Fernandes, R.A.

Fernandez, $H$.

Ferrara, G.

Ferris, J.G.

Feurer, D.A.

Finn, L.

Fischer, L.S.

Fishman, M.F.

Fishman, M.J.

Fitch, J.B.
$480 \quad 481 \quad 482$

$\begin{array}{ll}1647 & 1786 \\ 1000 & 1458\end{array}$

107

983

466

9999df

274

472

1080

1566

755

114

530

9999bx

1334

1376

1265

75

858

633

946

35

891

115

1557

1563

607

1001

896

271

116

22

1888

1002

$1544 \mathrm{ac}$

1550

897

$1482 \mathrm{cs}$

1471

9999ea

9999df

9999dj 9999dk

785
$1193 \mathrm{~g}$

151

941

1524

$\begin{array}{rrrrr}812 & 813 & 835 & 923 & 1248 \\ 1558 & 1559 & 1560 & 1561 & 1562\end{array}$

117 
Flemings, M.C.

1129

Fleniken, J.A.

Fletcher, E.A.

Flewitt, W.E.

Flock, J.W.

Flower, J.E.

898

1876

1444

Flower, W.L.

836

Foligno, $G$.

Fong, $P$.

260

Fontana, J.

502

Foote, W.R.

$293 \quad 294$

Ford, W.0., Jr.

106

899

Foss, A.S.

1815

Fossum, A.F.

Foster, G.H.

Fournier, R.0.

Fowler, J.M.

Fox, E.C.

$1582 \mathrm{ab} 1582 \mathrm{ac}$

1303

372

1822

118

Fox, M.

673

441

Foxworthy, B.L.

Fraas, A.P.

Fraley, S.K.

Francis, B.

Franck, P.A.

Franco, A.

Frangos, A.Z.

Fraser, M.D.

Frazor, D.R.

Frederick, W.J., Jr.

1003

187

1330

1572

814

$1482 \mathrm{ap}$

1004

562

1014

683

276

1005

905

1810

Frick, E.

Friedman, L.C.

9999df

Friedman, $M$.

Frind, E.0.

Fritton, D.D.

1370

1770

Frost, G.P.

Frysinger, G.R.

630

1006

1007

Fuchs, W.

1347

State University

Fujii, I.

1862

396

Fujii, J.

235

Fukunaga, P.S.

Fulford, R.S.

Fulton, R.L.

Funne 11, J.E.

$4191177 r$

Furman, E.R.

1065

1355

Furrer, M.

1810

Gabrysch, R.K.

120

Gajanana, B.C.

1008

Gale, J.E.

1387

$881 \quad 1179 \quad 1299 \quad 1339$

815

$876 \quad 1586 \quad 1698$

1324

1456 
Gallagher, B.J.

Galley, J.E.

Gallo, L.E.

Gallus, J.P.

Galowin, L.S.

Gamble, T.D.

Gambolati, G.

Gangarao, H.V.

Gangle, F.J.

Gannon, R.

Garcia-Bengochea, J.I .

Gardner, G.H.F.

Garg, S.K.

Garrett-Price, B.A.

Gartner, E.M.

Garton, R.R.

Garza, S.

Gass, T.E.

Gates, C.F.

Gates, G.L.

Gatto, P.

Gatts, R.R.

Gay, B.M.

- Geertsma, J.

Gelb, G.

Gelhar, L.W.

Gensler, W.G.

Geological Society of America

George, C.J.

Geothermal Resources Council

Geraghty, J.J.

Getzen, R.T.

Ghaffari, A.

Ghezzi, G.

Gibb, J.P.

Giddey, C.

Giese, R.F.

Gilbert, R.G.

Gilders leeve, O.D.

Gill, M.A.

Gillespie, J.B.

Gilliland, H.E.

Giovannoni, A.

Givoni, B.

Glasby, G.P.

Glaser, C.W.

Gleason, V.E.

Glenn, D.R.

Glenn, E.E.

Glover, R.E.

Godfrey, R.D.

Godwin, W.H.

Gogarty, W.B.
846

1313

1479

1493

765

$1177 \mathrm{~m}$

121

632

896

122

1420

641

32

1524

1138

1082

606

123

129

130

816

276

1130

$1544 \mathrm{~m} \mathrm{1482 \textrm {ao }}$

131

989

1587

1072

817

818

1578

1618

684

$9999 \mathrm{dz}$

433

133

1118

241

1254

1002

134

608

901

1375

135

686

1613

136

$\begin{array}{lll}688 & 692 & 1083\end{array}$

$\begin{array}{ll}687 & 1241\end{array}$

137

1836

759

902

1783

$276 \quad 1698$

1757

1579

$1177 \mathrm{aq}$

1376

685 $\begin{array}{lllll}124 & 125 & 126 & 127 & 128\end{array}$

$\begin{array}{llll}561 & 791 \quad 1905 & 1544 j\end{array}$ 
Golay, M.W.

Goldenberg, D.

Goldman, D.

Goldste in, N.

Goldste in, N.E.

Gol ibersuch, D.C.

Gonzalez, J.R.

Goranson, C.B.

Goranson, C.G.

Gordon, A.R.

Gordon, L.H.

Gore, L.A.

Gorman, R.

Gorzelnik, E.F.

Goss, M.J.

Goubau, W.M.

Government Institutes, Inc.

Govier, G.W.

Goyal, K.P.

Gozeinik, E.F.

Graf, A.N.

Graham, C.E.

Granados, E.

Grange, B.W.

Granne 11, R.B.

Grantham, C.K.

Gray, D.A.

Gray, G.R.

Gray, W.G.

Green, D.W.

Green, J.H.

Green, M.A.

Green, N.D.

Greenberg, J.S.

Greenberg, M.

Greenwald, R.

Greenwood, D.A.

Greenwood, P.B.

Gregg, D.0.

Gregory, M.W.

Gresko, T.M.

Greytok, F.

Griggs, D.T.

Grigu11, V.

Gring, L.M.

Gringarten, A.C.

Grist, D.M.

Groff, G.C.

Grogan, R.

Grol1, M.

Gross, R.J.

Ground Water Age

Grove, D.B.
$1544 w$

1496

470

609 1177e 1177h 1177m 1177n

689

1443

29

$1177 a b$

$\begin{array}{lllll}138 & 139 & 504 & 1242 & 1177 a a\end{array}$

382

713

1009

630

$1544 \mathrm{ar}$

1010

644

$1177 \mathrm{~m}$

1828

280

140

1644

1177 ah

291

33

1838

$1177 n$

142

285

59

144

146

417

147

$1360 \mathrm{n}$

$1482 \mathrm{ct}$

1733

$1177 \mathrm{aq}$

720

720

145

1011

692

314

1393

254

693

148

278

987

1476

1841

1544 ad

192

1371
1837

141690

143

$691 \quad 1183$

$\begin{array}{lllll}149 & 279 & 694 & 1210 & 1656\end{array}$

1402 
Growitz, D.J.

Grubaugh, E.K.

Grubbs, D.M.

Gruen, D.M.

Gucer i, S.I.

Guenther, K.L.

Guest, R.J.

Guha, T.K.

Gulati, M.S.

Gunn, T.L.

Gupta, B.P.

Gupta, S.K.

Gurevich, M.

Gustafson, G.

Gutjahr, A.L

Gutjahr, A.L.

Gutknecht, P.J.

Gutowsk i, R.R.

Guyer, E.C.

Gwyther, D.N.

Haas, J.L., Jr.

Haas, W.R.

Haberstroh, R.D.

Hackett, C.E.

Haddenhorst, F.A.

Hadley, W.A.

Hage, $G$.

Hagey, G.

Halderman, A.D.

Halevy, E.

Halfon, A.

Hall, E.H.

Hal 1, E.W.

Hall, R.C.

Hal 1, W.K.

Hallanger, E.C.

Ham, W.C.

Hame 1, B.B.

Hammond, R.P.

Hampe 1, V.E.

Hanck, J.A.

Haney, $J$.

Haney, J.P.

Hanna, W.T.

Hanold, R.J.

Hanor, J.S.

Hansen, V.E.

Hanson, J.M.

Hanson, M.E.

Hantush, M.S.

Harboe, $\mathrm{H}$.

Harbridge House, Inc.
1274

1753

821

857

1084

639

$1453 \mathrm{f}$

150

75

847

1244

1145

153

$1544 a$

695

1757

1587

1508

1850

277

1012

1205

1872

1811

1350

888

154

1414

622

1701

155

1292

1013

1664

1839

471

976

96

1008

630

1478

156

$1177 a b$

29

1014

1628

456

157

610

696

158

611

698

1678 $\begin{array}{lllll}852 & 853 & 854 & 855 & 856\end{array}$

$151 \quad 1697$

1314

13600

1147

$1479 \quad 1769 \quad 1897$

139

$1170 \quad 1256$

$\begin{array}{lllll}159 & 160 & 161 & 162 & 281\end{array}$ 
Hardee, J.

1436

Hare, R.C.

Hargadine, G.D.

170

Harling, O.K.

Harnish, J.R.

Harrar, J.

Harrar, J.E.

Harrigan, R.W.

Harrill, J.R.

Harris, M.J.

Harris, W.B.

Harrison, R.F.

Harrison, T.D.

Hart, D.H.

Hartford, J.C.

Hasbrouck, R.T.

Haslett, R.

Hastings, J.R.

Hatami, R.

608

$\begin{array}{lll}572 & 1109 & 1449\end{array}$

163

1476

905

1544 ad

1175

$1790 \quad 18851315 r$

$86 \quad 1266$ 9999ec 1383au

867

13831

441

888

1500

$1544 t$

822

1840

Hatasaka, S.M.

1133

Haugen, A.K.

Hausz, W.

906

164

$1383 a]$

$959 \quad 1324$

170

$165 \quad 166$

166

$171 \quad 172$

$167 \quad 168$

169

363

Hautala, R.R.

Havrilak, R.J.

1874

820

Hawkes, D.A.

1016

Hawk ins, M.F.

672

Hayashi, M.

$1579 \mathrm{bu}$

Hayden, $N$.

Hayes, M.E.

1544 ae

939

821

1393

701

1396

Healy, J.H.

$\begin{array}{lllll}1015 & 1333 & 1510 & 1664 & 1383 f\end{array}$

Heating and Ventilating News

964

Heating, Piping and Air

Conditioning.

Hedden, R.E.

Heess, $F$.

1201 1360aa

1841

470

177

Hege, $H$.

$315 i$

1841

822

1443

178

1017

1460

1603

179

1767

284

Helm, D.C.

180

Helweg, 0.J.

Hem, J.D.

908

Henderson, $\mathrm{J}$.

1311

1842

$\begin{array}{lllll}1184 & 1584 & 1749 & 1764 & 1765\end{array}$

$\begin{array}{lllll}1172 & 1185 & 1186 & 1187 & 1297\end{array}$ 
Henderson, R.L.

Hendricks, $V$.

Hendrickson, P.L.

Henry, H.R.

Henry, J.F.

Henry, J.M.

Herault, J.P.

Herbeck, E.F.

Hermannsson, S.

Hernandez, J.W.

Heronemus, W.E.

Herrick, C.S.

Hersh, H.N.

Hertzberg, A.

Herzog, P.

Hewitt, C.H.

Hibsch, G.

Higbee, C.V.

Higuera, M.G.

Hilberath, F.

Hildebrandt, A.F.

Hiler, E.A.

Hill, C.T.

$\mathrm{Hi} 11, \mathrm{~J}$.

Hil1, J.H.

Hill, R.A.

Hill, R.F.

Hiller, C.C.

Hirano, Y.

Hirshberg, A.S.

Hise, E.C.

Hoang, $V$.

Hockett, R.S.

Hockman, E.L.

Hodges, L.

Hodgk inson, D.P.

Hoeppner, S.

Hoffman, H.W.

Hoffman, J.A.

Hoffman, K.C.

Hoffmann, M.

Hogenson, G.M.

Hohn, $H$.

Hol T, R.J.

Holm, L.W.

Holman, A.S.

Holman, J.P.

Holmberg, J.G.

Holmes, B.G.

Holt, C.F.

Holt, L.

Holton, W.C.

Holtz, D.
75

1476

$15831582 \mathrm{~s}$

181

1004

1029

81

822

182

283

1260

$581383 y$

1544 e 1383af

$1482 \mathrm{u}$

1292

183

1597

327

1414

1823

969

425

184

1476

1503

836

826

$1193 \mathrm{~h}$

1690

255

1580

$1177 \mathrm{aq}$

1018

702

1887

1435

185

186

1178

1069

1903

1574

1299

1023

1846

909

1667

827

1615

130

582

622

188

21
$1482 y$

1818

$\begin{array}{llll}187 & 282 & 811 & 1019\end{array}$

1131 


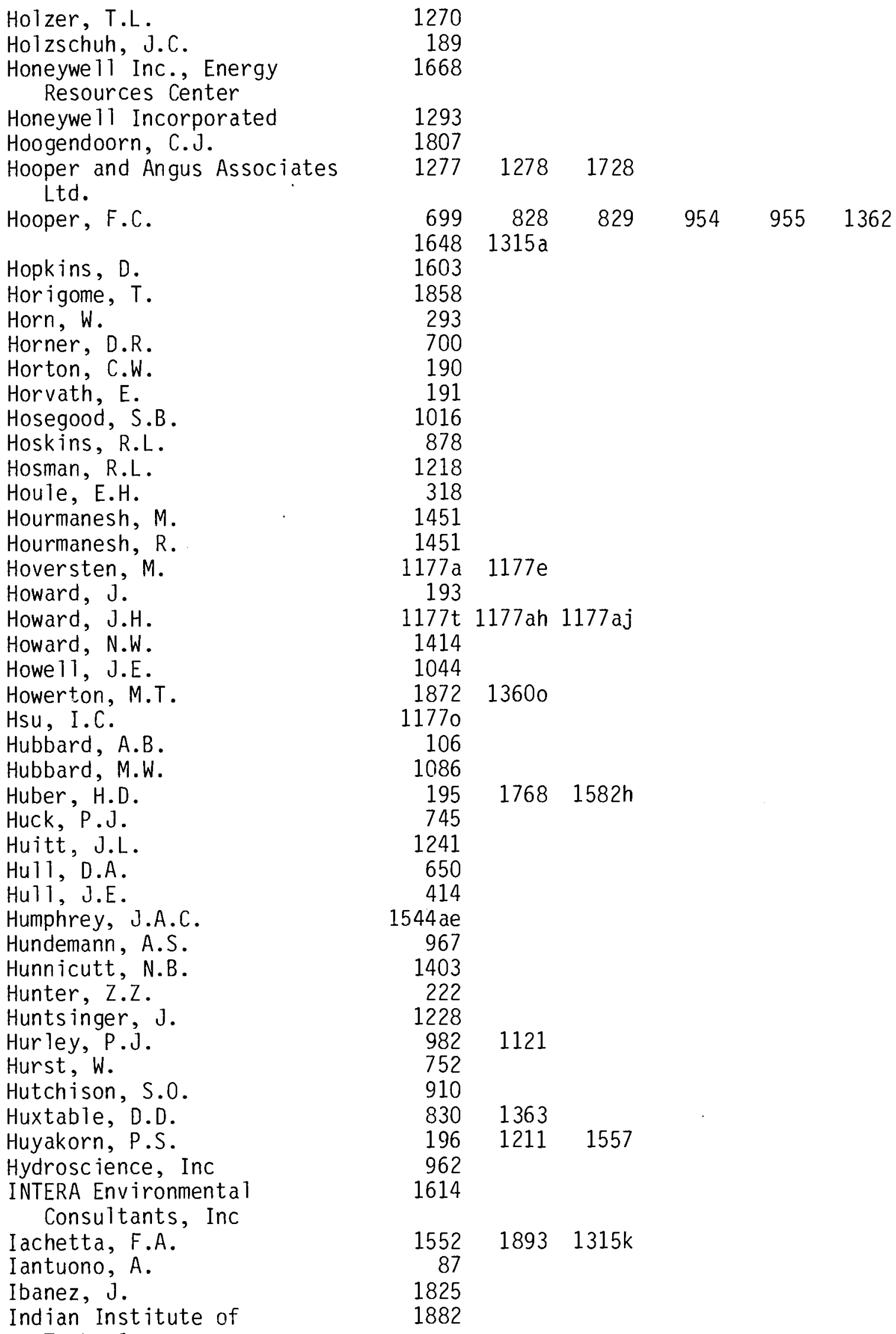

Holzer, T.L. 1270

Holzschuh, J.C. 189

Honeywe 11 Inc., Energy 1668

Honeywe 11 Incorporated 1293

Hoogendoorn, C.J. 1807

Ler and Angus Associates

1603

1858

293

1016

878

1218

318

1451

1451

$1177 \mathrm{a}$

1414

1044

1872

1770

106

1086

195

$44 \mathrm{ae}$

967

1403

222

228

982

752

196

962

1614

1552

1882

Techno logy 
Industrial Heating $\quad 1110$

Ineson, $\mathrm{J}$. 198

Ingram, H.M. $\quad 357$

Ingri, N. 1463

Intercomp Resource 199

Development and

Engineering, Inc

International Association of

1269

Scientific Hydrology and Unesco

International District Heating Association

International Gas Union, Int' 1 Institute of Refrigeration and Institute of Gas Technology

International Solar Energy Society - UK Section

International Solar Energy Society, UK Section

$1453 \quad 1454$

$1136 \quad 1137$

Intertechnology Corporation $\quad 1114$

Iof is, M.A. 1796

Iris, P. $\quad 78$

Iwai, K. $\quad 1387$

Izatt, R.M. $\quad 1465$

J. Donald Kroeker and 595 Associates

JRB Associate, Inc

Jacob, C.E.

1246

77

$\begin{array}{rrrrr}160 & 161 & 162 & 201 & 202 \\ 204 & 205 & 206 & 207 & 208 \\ 587 & & & & \\ 1235 & & & & \\ 1872 & 13600 & & & \end{array}$

Jacobs Engineering Co

209

1234

Jacobson, $L$.

1572

Jaeger, F.A.

1138

Jaehne, $H$.

1247

James, G.R.

1007

James, R.

210

Jameson, J.S., Jr. $\quad 831$

Janes, C.W. $\quad 1020$

Jank, R. 211

Jannol, M. $\quad 1346$

Japhet, R.E. $\quad 212$

Jardine, D.M. 832

Jaske, R.T. 450

Javande l, I. $\quad 876$

Jayadev, T.S.

Jefferson, J.W.

1311

Jenkins, D.

617

Jenkins, G.H.

Jenkins, $N$.

Jet Propulsion Laboratory

Jimenez, M. 
Johansson, $M$.

1620

John Hix, Scanada, and Acres 1723 Shawinigan Ltd.

John Wiley and Sons

Johns Hopkins University, Applied Physics Laboratory

Johnson Division, UOP Inc

Johnson, A.B., Jr.

Johnson, A.E.

Johnson, A.I.

Johnson, C.E.

Johnson, G.

Johnson, H.B.

Johnson, H.E.

Johnson, K.E.

Johnson, R.C.

Johnson, T.L.

Johnson, W.C.

Johnston, P.A.

Jones, D.W.

Jones, L.L.

Jones, R.

Jones, S.C.

Jones, T.E.

Jorda, R.M.

Jorgensen, D.G.

Joseph, D.D.

Juprasert, S.

Just, R.E.

Kahan, C.V.

Kahn, J.S.

Kakolowicz, W.

Kalhammer, F.R.

Kalousek, G.L.

Kam, W.

Kamimoto, M.

Kanehiro, B.Y.

Kaneko, T.

Kaplan, I.R.

Kaplan, S.I.

Kapner, M.

Karadi, G.M.

Karanjac, J.

Karnitz, M.A.

Karpuk, M.E.

Karr, M.H.

Kartsounes, G.T.

Kas ameyer, P.W.

Kasparyan, E.V.

Kassoy, D.R.

Katayama, K.

Katter, L.B.

Katz, D.L.

Katz, M.L.

961

1542

1188

911

893

755

215

1861

1806

704

216

772

832

217

622

708

370

1488

705

1430

$1177 \mathrm{~V}$

1245

1190

696

1463

706

218

1274

1858

635

642

1233

1908

9999dq

833

1247

1486

1021

739

1551

1796

140

707

878

221 $\begin{array}{llllll}1378 & 1379 & 1380 & 1381 & 1382 & 1541\end{array}$

$1330 \quad 1368$

96

1177 am 1177 ao

$12399999 a$

1784

$512 \quad 513$

371

$\begin{array}{lll}1497 & 1501 & 1502\end{array}$

$\begin{array}{lll}13 & & \end{array}$

$1177 \mathrm{z}$

$1207 \quad 1696$

1440

$\begin{array}{llll}141 & 219 & 220 \quad 690\end{array}$

$16101544 a \mathrm{i}$

$653 \quad 708 \quad 729$ 
Katzer, $M$.

Kauffman, K.W.

Kaveler, H.H.

Kavernen Bau-Und Betrieds-GMBH

Kazmann, R.G.

Keady, D.M.

Kedl, R.J.

Keeley, J.W.

Keenan, J.H.

Keener, H.M.

Keese, J.A.

Keith, W.

Kelldorf, W.F.N.

Keller, C.E.

Keller, G.L.

Keller, J.G.

Kelly, G.E.

Kelly, J.E.

Kelly, W.E.

Kelm, C.H.

Kemper, W.D.

Kennedy, A.S.

Kennedy, K.G.

Kent, D.C.

Kestin, J.

Keyes, F.G.

Keys, W.S.

Khaleel, R.

Khalifa, H.E.

Khan, A.M.

Kihara, D.H.

Kilgore, L.A.

Kilpatrick, F.A.

Kimbler, O.K.

Kimme 1, G.E.

King, $S$.

Kinney, R.B.

Kipp, K.L.

Kirchner, R.P.

Kirkham, D.H.

Kirschbaum, H.S.

Kirvela, K.

Klarsfled, S.M.

Kley, W.

Klinkenberg, L.J.

Klootwijk, P.H.

Klotz, D.

Knauss, K.G.

Knight, J.E.

Knowles, D.B.

knowles, G.R.

Koch, R.K.
1664

1094

222

913

223

237

229

187

454

612

$1315 f$

914

$1360 n$

899

230

1730

$1482 \mathrm{aa}$

1745

12

1735

932

231

1022

145

379

1748

612

232

234

1748

3

235

709

710

114

1192

593

1785 ap

450

1089

177

623

$1453 \mathrm{c}$

238

239

711

875

1797

1475

1464

897

1886

712
$1141 \quad 1843 \quad 1844 \quad 1315 h$

$\begin{array}{lllll}224 & 225 & 226 & 227 & 228\end{array}$

$\begin{array}{llll}228 & 236 & 237 & 295\end{array}$
915

1546

$233 \quad 834$

1695

521

$798 \quad 1019 \quad 1131$

15

834

1695 
Koederitz, L.F.

1335

Koenig, E.F.

Koenig, J.B.

Kolb, J.0.

Komedera, $M$.

Konczak, $Z$.

$1453 n$

286

715

Konieczek, J.

875

Kopp, J.F.

1800

Korsgaard, $V$.

1566

Kosaka, M.

1090

Kosky, P.G.

58

Kouma, E.

1438

Kouvalis, A.

Kovach, E.G.

1117

625

Kowalewska, J.

1342

Krajewski, R.

1325

Kranzler, G.A.

993

Krause, C.

1091

Kreft, A.

1597

Kreid, D.

1545

Kreider, K.G. $\quad 1142$

Kreith, F.

1193

Kreitler, C.W. $\quad 1694$

Kreitlow, D.B. $\quad 596$

Kretsch, J.L. 1477

Krishnaswamy, V.S. $\quad 287$

Kriz, T. 1900

Kroeger, P.G. $\quad 288$

Kroeker, J.D. 289

Kron, N., Jr. 1632

Kruger, $P$. $\quad 916$

Krupka, K.M. 1352

Kryukov, P.A. $\quad 292$

$\mathrm{Ku}, \mathrm{H} . \mathrm{F} . \mathrm{H}$.

1427

$599 \quad 600 \quad 615$

Kuehlert, H.F.

Kugeler, $K$.

Kugeler, $M$.

Kukacka, L.E.

Kumar, A.

Kunze, J.F.

Kunze, J.K.

Kurosaki, $Y$.

Kurt, C.E.

Kurz, M.G.

Kustas, F.M.

Kusuda, T.

Kutatel adze, S.S.

$1383 \mathrm{v} 1544 \mathrm{k}$

1023

1023

293

295

1455

1593

$1193 \mathrm{C}$

1806

$1454 \mathrm{a}$

1368

296

1423

$290 \quad 291$

1085

1683

294

$847 \quad 917 \quad 1798$

Kutel, C.R.

Kuuskraa, V.A.

1874

796

LaFayette, C.R.

837

LaGarde, A.

297

LaMarche, N.

1015

1730

Lacher, P.J.

Laird, A.D.K.

87911770 
Laity, W.W.

Lakshminarayana, $V$.

Lamb, J.P.

Lamers, M.D.

Lamich, G.

Lamich, G.J.

Lampinen, B.E.

Lance, J.C.

Land, C.S.

Lande 1, P.A.

Landreau, A.

Landrum, A. 0 .

Lane, R.

Lang, S.M.

Lang, $W$.

Langenheim, R.H.

Langhetee, E.J.

Langley, G.O.

Langmuir, $D$.

Lantz, R.B.

Lappillonne, B.

Lapwood, E.R.

Larionov, E.G.

Larson, S.P.

Larson, W.E.

Lauwerier, H.A.

Lawand, T.A.

Lawn, J.

Lawrence Berkeley Laboratory

Lawrence Berkeley Laboratory, Earth Sciences Division

Lawrence Berkeley Laboratory, Energy and Environment

Division

Lawrence Livermore Laboratory

Lawrence Livermore

Laboratory, Earth Sciences

Division

Lawrence Livermore

Laboratory, Energy and

Resource Planning Group

LeCroy, J.E.

LeFrois, R.T.

Leas, R.

Ledbetter, C.W.

Ledentsova, N.A.

Lee, $C$.

Lee, D.A.

Lee, K.H.

Lefebre, $V$.

Leffler, A.J.

Leflar, J.

Leggette, R.M.

Lehr, J.H.
1346

298

1482ee

1281

1878

1877

1850

1254

799

1210

694

837

1798

299

300

336

1264

278

1799

645

1589

301

292

399

735

302

1105

1813

304

305

1208

303

1474

1601

1491

1177

$\begin{array}{lllll}306 & 307 & 308 & 1512 & 1576\end{array}$

716

$956 \quad 1452 \quad 1560$

859

1111

$1453 n$

1315 t $9999 \mathrm{eb}$

101

1022

1024

$1177 \mathrm{a}$

309

1889

13151

310

$16171383 a j \quad 1886$

60

$128 \quad 129 \quad 311$

312

514 
Leiby, C.C.

Le idenfrost, $W$.

Leigh, R.W.

Lenz, $T$.

Lenzer, R.C.

Lepper, F.R.

Les, J.G.

Lesem, L.B.

Leshuk, J.

Leshuk, J.P.

Lessard, R.D.

Leutwyler, $k$.

Levine, E.P.

Lewis, C.J.

Lewis, D.

Lewis, L.G.

Lewis, R.W.

Li, K.W.

$L i, W . H$.

Liao, C.K.

Libowitz, G.G.

Lichtler, W.F.

Lidorenko, N.S.

Lienau, P.J.

Lienhardt, M.J.

Lightfoot, E.N.

Lilleleht, L.U.

Lin, C.P.

Lin, E.I.H.

Lind, C.J.

Lindemuth, T.E.

Lindorff, D.E.

Lindroth, D.P.

Lins, T.W.

Lior, N.P.

Lippmann, M.J.

Livesay, B.J.

Livingston, $P$.

Lo, H.Y.

Locke, F.E.

Loddo, M.

Loehrke, R. I.

Lofgren, B.E.

Lohman, S.W.

Lohse, D.

Lopez, L.

Lorensen, L.E.

Lorsch, H.G.

Los Alamos Scientific
$573 \quad 1366$

1143

1831

$1679 \quad 1898$

1875

313

828

$1454 \mathrm{~s}$

314

1109

572

$1582 \mathrm{v}$

1406

1631

1711

1873

739

1708

1808

315

639

1093

1438

713

316

786

694

750

$1265 \quad 1552$

$1383 \mathrm{v} 1544 \mathrm{k}$

$1360 \mathrm{q} 1785 \mathrm{bs}$

1187

318

319

714

229

1094

320

530

1177 af

88

26

717

$905 \quad 960 \quad 1324$

1431

933

570

209

1025

1825

905

1095

$1315 \mathrm{~h}$

1149
1851

$\begin{array}{lllll}317 & 326 & 327 & 616 & 624\end{array}$

$1482 y$

$1893 \quad 1193 \mathrm{~g} \quad 1315 \mathrm{k}$

321

1197

$\begin{array}{llll}322 & 502 & 503 & 504\end{array}$

$1242 \quad 1527 \quad 15951177 \mathrm{ae}$

1177ag 1177ak 1177al 9999r

$\begin{array}{lll}571 & 1194 \quad 1693\end{array}$

779 
Laboratory Loscutoff, W.V. Louden, L.R.

Lovering, T.S.

Lowe, P.A.

1692

Lowe 11, R.P.

1106

Loy, S.E.

246

Lucido, V.D.

Ludwig, N.C.

Luikov, A.V.

Lummus, J.L.

Lund, J.W.

Lundberg, W.L.

Lundstrom, L.

324

626

1740

718

1398

317

$1482 \mathrm{y}$

$325 \quad 326$

1312

1026

1144

Luschi, E.

328

1375

Luthin, J.N.

153

Lutkestratkotter, $\mathrm{H}$.

1777

Lynch, E.J.

Lynde, E.J.

Lynn, S.

329

M.A, Combarnous

MCC Associates, Inc.

Mabey, D.R.

MacCracken, C.D.

MacFarlane, W.T.

Maclay, R.W.

Madden, T.R.

Maddock, $T$.

Madhav, M.R.

Magnuson, E.E.

Mahon, W.A.J.

Mahony, F.0.

Majer, E.L.

Malcolm, R.L.

Malherbaud, $J$.

Malina, J.F., Jr.

Mallow, W.A.

Malofeev, G.E.

Maly, G.P.

Manahan, S.E.

Manetti, G.

Mangold, $D$.

Mangold, D.C.

Manson, $C$.

Mansure, A.J.

Manvi, R.

Mar, R.W.

Marconc ini, R.

Margen, $P$.

Margen, P.H.

Marianowski, L.G.

Marie, J.P.

2

1815

1706

1581

1386

$1315 d$

884

1196

52

330

331

1096

1646

983

$1177 \mathrm{f}$

$9999 \mathrm{cw}$

89

768

$9999 \mathrm{cx}$

782

1676

333

1550

1177 al

1197

1673

1528

1544 af

1895

443

334

1027

1028

1582

$1177 i \quad 1177 j$

13830

$919 \quad 957$

$1247 \quad 1473$

Marine, I.W. 
Marks, S.B.

Marotta, F.

Marovel1i, R.L.

Marsden, S.S.

Marshal1, R.H.

Martin, J.B.

Martin, J.F.

Martin, J.H.

Martin, J.J.

Martin, P.J.

Martin, W.L.

Martinez, R.H.

Martinez-Baez, F.

Martini, W.R.

Martinovic, J.

Maru, H.C.

Marx, J.W.

Mashiko, Y.

Masica, W.J.

Maslowski, B.

Maslowski, $C$.

Mason, D.C.

Massey, R.G.

Mather, J.D.

Mathey, B.

Mathur, A.K.

Matthews, C.S.

Maurer, W.C.

Mayotte, R.J.

Maza, B.G.

McAlevy, R.F.

McBeth, R.L.

McCabe, J.E.

McCaffey, F.G.

McCain, W.D.

McCarthy, R.L.

MCClenahan, J.D.

McConne 11, T.D.

McCord, J.R.

McCormick, P.0.

McCormick, R.J.

McCuen, R.H.

McCune, C.C.

McCurry, D.C.

McDonald, C.

McDonald, C.F.

McDonald, C.L.

McDonald, J.R.

McDonald, J.W.

McDonnel1 Douglas

Astronautics Company

McEdwards, D.

McEdwards, D.G.

McEThaney, G.W.
1482 ao

314

719

738

$1193 j$

1390

1447

$1544 b \quad 1544 c$

86
106

1121

1416

1029

$1177 \mathrm{aq}$

1062

985

1028

336

1690

868

1118

792

473

1130

720

337

411

1261

1399

14541

756

1909

1084

1363

568

349

1083

955

1629

669

1151

1122

721

340

1291

1228

1097

35

181

1834

1132

$\begin{array}{lll}338 & 339 & 569\end{array}$

$\begin{array}{lll}1408 & 1617 & 1886\end{array}$

1362

$195 \quad 341$

382

1354

996

\section{886}

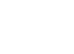

$1177 \mathrm{ab}$

346 
McEvilly, T.V.

McFarland, C.R.

McGarity, A.E.

McGaw, R.

McGlothlin, R.E.

McGowan, J.G.

McGrogan, S.K.

McKee, G.D.

McKetta, J.J.

McLean, G.0.

McMillion, L.G.

McNabb, J.F.

McNeil, M.B.

Meador, R.

Mech, A.R.

Medica, P.A.

Meehan, D.N.

Megley, J.W.

Meidav, H.T.

Meinzer, 0.E.

Melsheimer, S.S.

Melville, J.G.

Mendelsohn, $M$.

Menjoz, A.

Menzie, D.E.

Mercado, A.M.

Mercado, S.

Mercer, J.W.

Merino, M.

Merriam, M.F.

Messer, P.H.

Messmer, J.H.

Metz, P.D.

Meyer, A.F.

Meyer, C.F.

Meyer, F.W.

Meyer, W.R.

Meyers, A.C.

Meyers, J.E.

Meysenburg, $H$.

Michaels, A.E.

Michaels, A.I.

Michel, $H$.

Michel, J.W.

Mid-Continent District Study

Comm. on Cementing

Practices and Testing of

0i1-We 11 Cements

Midwest Research Institute

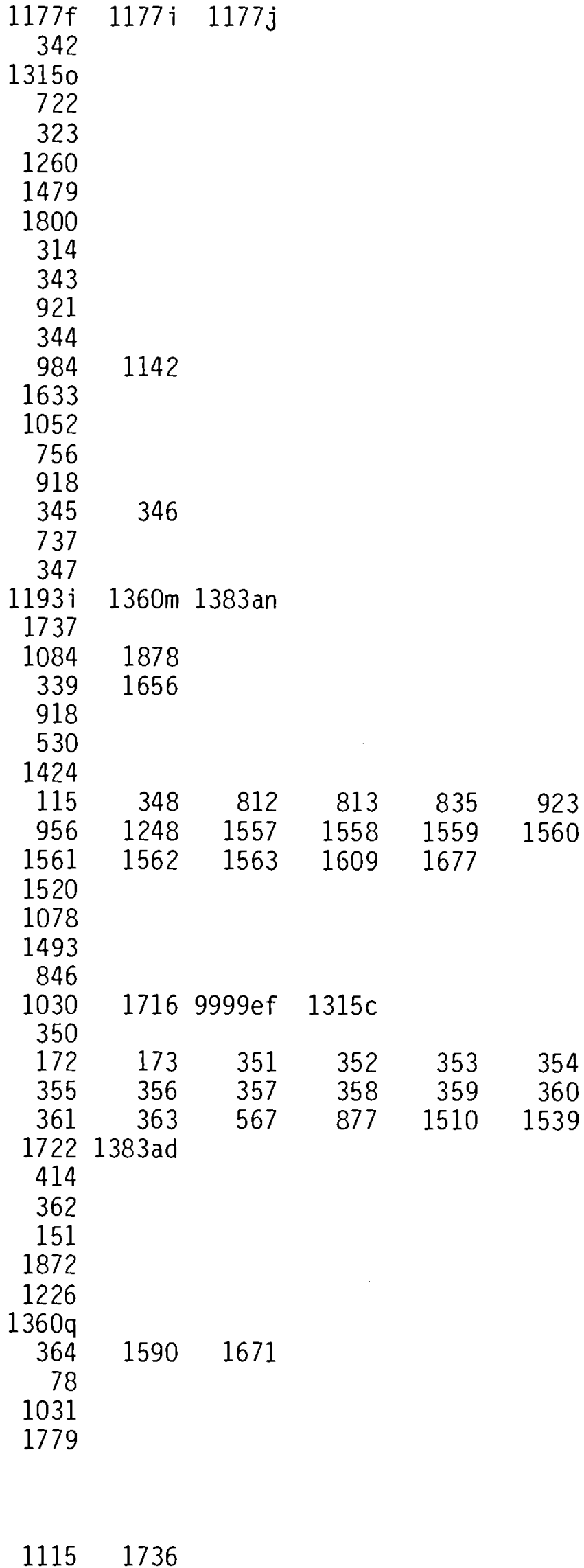


Mifflin, M.D.

Mikherjec, D.P.

Milburn, H.L.

Mileris, $G$.

Miles, C.R.

Millard, $V$.

Miller, C.W.

Miller, D.W.

Miller, F.M.

Miller, I.

Miller, R.E.

Miller, R.L.

Milis, L.G.

Milora, S.L.

Milton, H.W., Jr.

Mimura, $T$.

Minkowycz, W.J.

Minnesota Energy Agency

Minor, J.E.

Mitche 11, J.

Mitche 11, P.D.

Mitta 1, B.N.

Mlodinow, L.D.

Moden, R.

Modin, B.

Moesta, $\mathrm{H}$.

Mohtadi, M.F.

Molz, F.J.

Monte, R.

Moody, M.M.

Moody, W.T.

Moore, D.

Moore, G.L.

Moran, L.K.

More 1-Seytoux, H.J.

Morey, G.W.

Morgan, B.E.

Morgan, M.T.

Morgan, O.M.

Mor i, $Y$.

Moriarty, M.P.

Moritz, P.S.

Morre 17, G.0.

Morris, D.A.

Morris, G.E.

Morrison, F.A., Jr.

Morrison, H.F.

Moseley, J.C.

Moser, $H$.

Moses, T.H., Jr.

Moskvicheva, V.N.

Moss, J.T.
1700

584

365

1049

594

566

366

1618

1138

1564

565

1482bx

$1315 y$

564

894

1579bu

724

9999dy

1358

1193

1145

1104

$1177 y$

1295

1572

557

635

368

626

$17371383 a v$

1362

1240

137

642

1033

1783

538

372

1741

1331

1544 ap

1418

1034

1544 ar

$75 \quad 1198$

$1189 \quad 1207$

618

680

$1177 \mathrm{a}$

768

1797

563

1423

373

1651
$367 \quad 502$

$\begin{array}{lllll}369 & 370 & 371 & 512 & 513\end{array}$

1207

1177 e $1177 k$ 


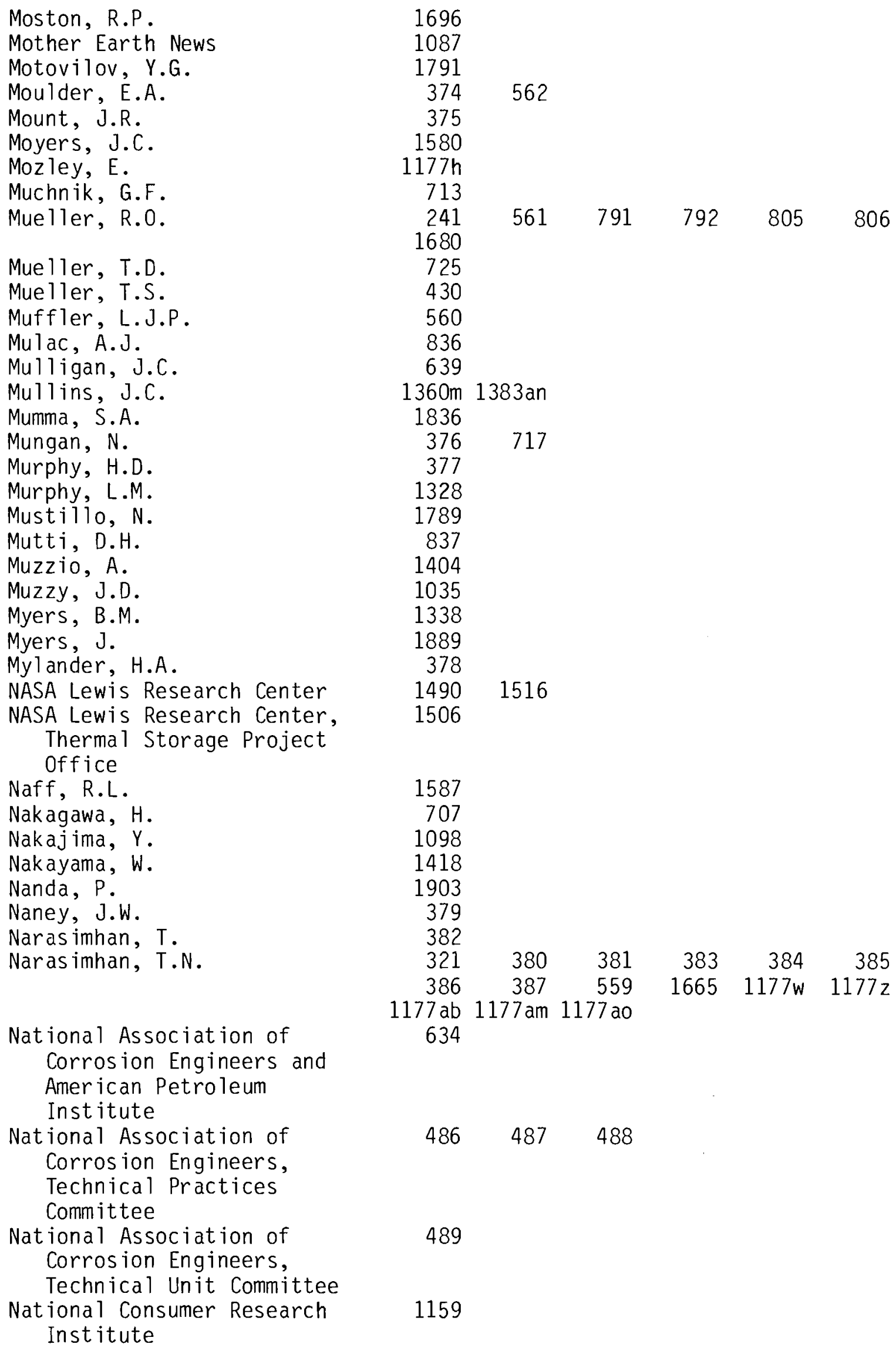

562

$\begin{array}{lllll}561 & 791 & 792 & 805 & 806\end{array}$

1516

$1177 \mathrm{ab} 1177 \mathrm{am} 1177 \mathrm{ao}$

634

$\begin{array}{lll}486 & 487 & 488\end{array}$ 
National Research Council,

398

U.S. National Committee for Rock Mechanics

National Swedish Board for

1276

Technical Development

National Water Well

Association

\section{Nature}

Nayfeh, A.H.

Nazli, M.

Neal, J.W.

Neil, J.M.

Nekoksa, G.

Nellor, M.H.

Nelson, C.G.

Nelson, S.H.

Nemecek, J.J.

Ner i, G.

Nestle, A.C.

Netherton, R.

Neuman, S.P.

Neurath, R.

Neustadter, E.L.

Newcomb, R.C.

Newman, M.E.

$\mathrm{Ng}, \mathrm{F} . \mathrm{W}$.

Nguyen, C.V.

Nicholls, R.L.

Nicholson, E.W.

Nielsen, C.E.

Niemi, W.L.

Nieskens, H.G.

Niessen, H.D.

Niles, P.W.

Nir, A.

Nixon, J.M.

Noble, J.E.

Nolen, J.S.

Noll, S.

Noran, D.

Norris, R.A.

Norton, D.

Nougarede, F.

Noyes, R.

Nuclear Research Centre

Nurmi, H.E.

Nwude, J.K.

O'Brien, L.J.

O'Del l, P.M.

0'Gorman, T.J.

0'Leary, $J$.

$\begin{array}{lllll}558 & 784 & 892 & 903 & 1570\end{array}$

275

1263

541

1146

1177 as

156

1655

926

791

$1544 u$

443

215

1499

387

1537

278

1296

388

402

1751

555

1099

1100

1496

239

1023

1069

155

1084

$1177 a i$

727

1718

838

609

1462

94

841

$1500 \quad 1537$

543

876

726

1743

14530

1147

842

1426

$1544 \mathrm{ar}$

1094

0 'Neill, $\mathrm{K}$.

Oak Ridge National Laboratory

Oaksford, E.T. 


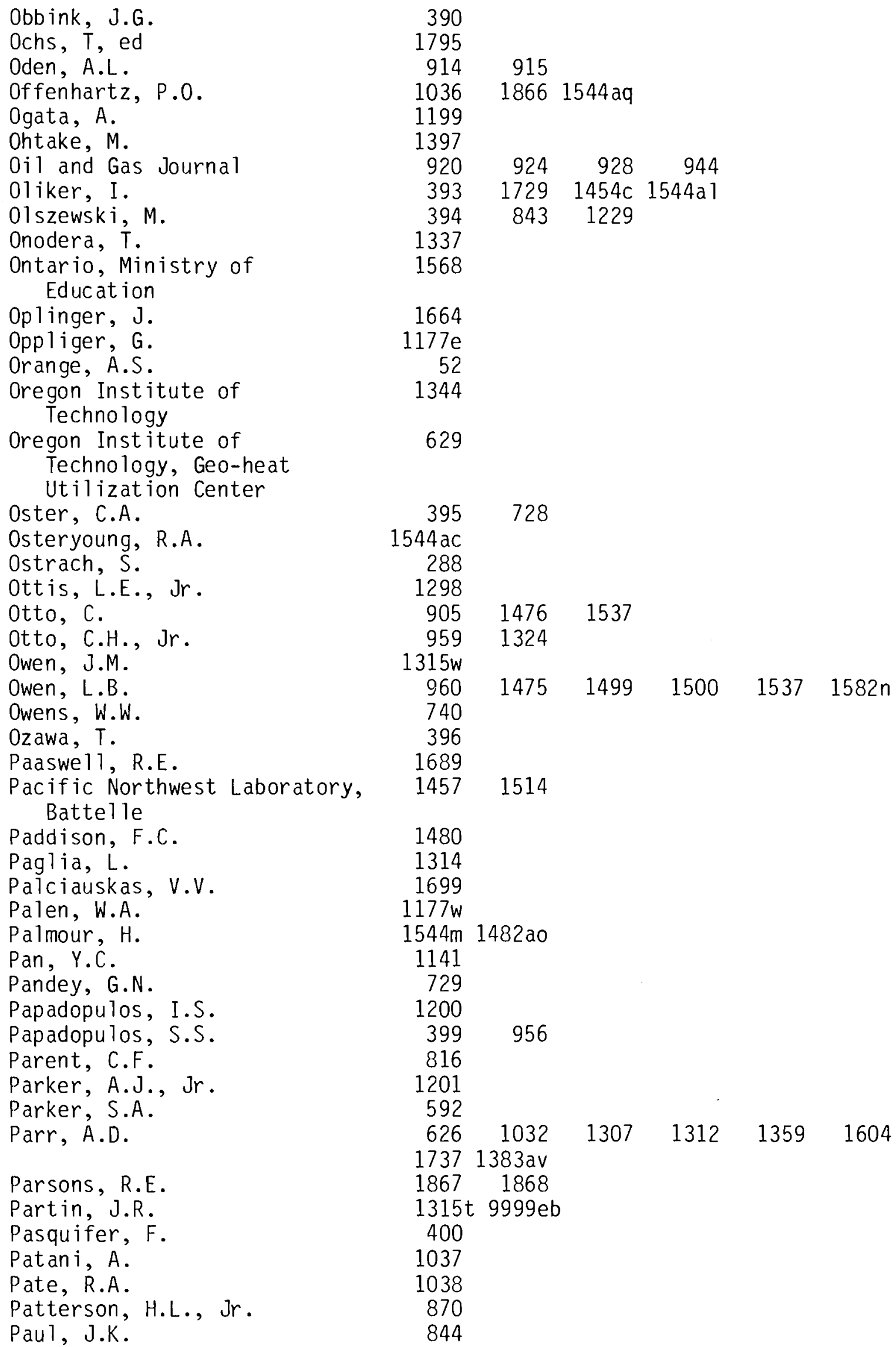


Pawloski, G.

Paynter, W.T.

Peart, R.M.

Peaudecerf, P.

Peiper, J.C.

Pelka, W.

Pemster, J.P.

Pence, S.A.

Penrod, E.B.

Perers, B.

Perkins, T.K.

Perry, $H$.

Perry, R.A.

Persons, J.L.

Peterman, D.

Peters, R.R.

Peterson, F.L.

Peterson, J.S.

Peterson, S.H.

Petin, Y.M.

Petri, R.J.

Petroleum Engineer

Pettibone, C.A.

Pettitt, R.A.

Pettyjohn, W.A.

Peube, J.L.

Pezdirtz, G.E.

Pfannkuch, H.O.

Pferdehirt, $W$.

Phillips, R.C.

Phillips, S.L.

Phillips, W.F.

Phoenix, D.A.

Pierce, B.L.

Pierce, R.L.

Pietsch, A.

Piety, R.G.

Pimenta 1, K.D.

Pincus, H.J.

Pinder, G.F.

Pines, H.S.

Pinkerton, $D$.

Piper, A.M.

Pirson, S.J.

Pitt, W.A., Jr.

Pittard, F.J.

Pitzer, K.S.

Planning Research Corporation

Plantikow, $U$.

Plummer, K.H.

Podlaseck, S.E.

Poland, J.F.

Polansky, G.F.
1414

894

1303

694

1177 ar

1660

1866

1740

401

957

402

929

1711

1364

1228

403

1267

404

1533

1423

1845

194

993

405

410

1942

1600

849

1632

509

411

1038

1219

1039

1688

1834

1203

1240

458

348

147

989

413

457

414

1628

$1177 \mathrm{ar}$

1880

1243

415

1872

416

1204

1482ee
1202

1485

1701

$1544 s$

$\begin{array}{lllll}406 & 407 & 408 & 409 & 1625\end{array}$

1592

$\begin{array}{lllll}412 & 1452 & 1557 & 1659 & 1763\end{array}$

419 1177s

$\begin{array}{lllll}417 & 418 & 497 & 591 & 730\end{array}$ 
Poling. B.E

Pollack, J.A.

Pollock, D.W.

Polzer, W.L.

Polzien, R.E.

Poole, D.R.

Pope, G.A.

Pope, W.L.

Porter, R.W.

Potorti, J.E.

Potter, R.W.

Powe 11, J.D.

Powe 11, J.R.

Powe 11, W.R.

Powers, L.W.

Powers, M.L.

Prater, L.S.

Prats, M.

Prenger, F.C.

President's Water Policy Implementation, Task Force 9

Price, C.E.

Price, D.

Price, M.

Pridmore, D.

Pril1, R.C.

Projanski, C.S.

Pruess, K.

Pryor, T.L.

Public Service Electric Gas

Co.

Public Utilities Fortnightly

Public Works

Pulick, M.A.

Purdy, I.L.

Pusch, W.H.

Puts, J.J.

Pye, D.S.

Pyle, D.E.

Quade, R.

Quade, R.N.

Qualheim, B.J.

Quan, D.

Quong, R.

Qvale, E.B.

$R P C$, InC

Raats, P.A.C.

Rabbimov, R.T.

Raber, $E$.

Rabi-Baliga, B.

Rabl, A.

Rachford, T.M.

Radebold, R.D.
$1360 r$

446

1674

1187

1544 ah

830

869

147

1319

1417

731

1329

1329

583

528

1416

1481

845

1811

1531

1275

441

442

$1177 \mathrm{a}$

1189

895

440

1076

1227

1666

197

1850

906

802

9999ea

1493

1783

1228

1041

1414

1133

960

420

1525

733

422

1537

762

1100

415

1847
$419 \quad 1177 u$

1205

$\begin{array}{lllll}1040 & 1268 & 1760 & 1761 & 1762\end{array}$

1769

1687

$1175 \quad 1206$

$1207 \quad 1417$

$4431177 \mathrm{ac}$

$1475 \quad 1498$

421

1526

$423 \quad 424$

1900 
Radosevich, L.G.

1437

Rae, J.

Raetz, J.E.

Ragland, H.C.

Rahman, M.A.

Raimondi, $P$.

Rajagopalan, S.P.

Raleigh, C.B.

Ramakumar, R.

Ramanathan, $V$.

Rambo, J.T.

Ramey, H.J.

Ramey, H.J., Jr.

Ramsey, H.J., Jr.

Randa 11, R.A.

Rande 11, J.E.

Ranney, M.W.

Rao, S.K.

Rapoport, L.A.

Rathmacher, $A$.

Ratigan, J.L.

Rausch, R.A.

Rawson, D.L.

Ray, J.

Raymond, E.

Raymond, J.R.

Raynor, D.G.

Read, W.R.

Recordon, E.

Redde 11, D.L.

Reed, D.B.

Reed, J.E.

Reed, M.G.

Reed, R.D.

Reed, R.S.

Reeder, H.O.

Reedy, W.R.

Reeves, M.J.

Reffstrup, $J$.

Reid, R.L.

Reilly, R.W.

Reimels, R.

Reisenauer, A.E.

Reistad, G.M.

Remmers, H.E.

Republic Geothermal, Inc.

Riaz, M.

Rice, R.C.

Rice, R.E.

Richards, W.D.

Richenderfer, J.L.

Ridgeway, $J$.
1415

1846

759

425

846

298

1393

1042

$1383 \mathrm{e}$

1283

738

18

867

916

13831

931

848

1101

669

326

974

1145

630

1825

1259

1569

1441

1102

569

102

1753

1752

1775

428

1043

1011

1209

987

31

1433

$1544 n$

1445

1044

450

$1315 y$

9999dr

762

1254

$1383 q$

1045

895
1396

$1284 \quad 1286$

$\begin{array}{lllll}279 & 426 & 518 & 627 & 847\end{array}$

1897

$\begin{array}{lllll}234 & 1266 & 1654 & 1657 & 1752\end{array}$

$1494 \quad 1536$

256

1434

$1768 \quad 1582 \mathrm{~h} \quad 1582 \mathrm{u}$

$\begin{array}{llll}84 & 85 & 602 & 785\end{array}$

$\begin{array}{llll}849 & 1547 & 1596 & 1809\end{array}$ 
Ridgeway, S.L.

Rie, $H$.

Rima, D.R.

Rindt, B.A.

Ringle, J.C.

Ritland, P.D.

Ritter, A.B.

Rivera R, J.

Riveros, $C$.

Rizzuto, J.E.

Roach, $F$.

Roache, P.J.

Roback, J.sJ.

Robeck, G.G.

Roberson, C.E.

Robert S. Kerr Environmental

Research Laboratory and

National Water Well

Association

Robertson, D.C.

Robertson, J.C.

Robertson, S.J.

Robeson, K.A.

Robichaux, J.

Robinson, P.C.

Rocket Research Company

Rodriquez-Amaya, C.

Roefs, T.G.

Rogan, J.E.

Rogers, F.C.

Rogers, F.T.

Rogers, P.Z.

Rohwer, $C$.

Rohy, D.A.

Rojey, A.

Roller, W.L.

Rollo, J.R.

Romagnoli, P.

Roman, A.J.

Roman, $\mathrm{K}$.

Romberger, J.S.

Romero, J.C.

Ronquille, J.D.

Root, R.L.

Rose, K.S.

Roseen, R.

Rosenzweig, S.

Ross, P.N.

Roszelle, W.0.

Roth, C.

Rothbaum, H.P.

Rousseau, W.F.

Rouve, $G$.

Rowe, J.J.

$\begin{array}{rl}429 & 630 \\ 11770 & \\ 1338 & \\ 1291 & \\ 602 & \\ 1046 & \\ 1896 & \\ 1177 \text { ag } & 9999 r \\ 1177 \mathrm{e} & \\ 1544 d & \\ 1630 & \\ 430 & \\ 1754 \\ 431 \\ 1187 \\ 770\end{array}$

932

1130

1151

1075

432

1415

1152

$1290 \quad 1384 \quad 1675$

590

49

1133

735

190

$1177 \mathrm{ar}$

404

1820

992

$1315 f$

273

433

1147

1564

993

434

887

1782

850

589

1902

586

912

1771

1001

1284

1777

372

$1473 \quad 1485$ 
Rowny, P.E.

Rozenfeld, L.M. $\quad 435$

Rubeck, M.

982

Rubey, W.W.

1393

Rubin, A.

1247

Rubin, A.M.

Rubin, $H$.

$1454 c$

Rubinshte in, L.I.

436

437

Rudd, N.

Ruffilli, C.

$1582 \mathrm{ad}$

Runberg, G.W.

528

Rushton, K.R.

438

1261

Russe 11, D.G.

229

Russe 11, E.E.

1143

Ryan, T.G.

1748

Ryley, D.J.

Ryon, R.W.

Saari, R.

Saaski, E.W.

Sabey, J.

Saffman, P.G.

Sagar, B.

959

1048

1062

231

444

1598

Saha, $H$.

1594

Saitoh, T.

1747

Sakhuja, R.

1049

Sakurai, S.

631

Sakuta, K.

1858

Sala, D.L.

1771

Saleem, Z.A.

Saleta, V.A.

Saliev, R.P.

1294

587

$1453 d$

445

Salieva, R.B. $\quad 445$

Salk, M.S. $\quad 776$

Saltzman, B. $\quad 446$

Salvat, $J$.

Salyer, I.0.

Samuels, G.

1413

1003

133

Sanderson, E.W.

Sandia Livermore Laboratory

108

Sandia National Laboratories $\quad 1515$

Sandquist, G.M.

Santing, G.

1593

736

1631

1103

$737 \quad 738$

Santoleri, J.J.

Sanya l, S.K.

1288

1249

Sapsford, C.M.

1104

Sarkar, S.

588

Sarot, J.

1495

Sasman, R.T.

Sass, J.H.

563

Sather, N.F.

739

Saugy, B.

Saulnier, B. 
Sauty, J.P.

Savage, S.B.

Savage, W.F.

1105

Sawata, S.

Saylor, W.

Scaringe, R.P.

Schaetzle, W.J.

Schafer, D.C.

1146

1858

1068

$1360 \mathrm{ac}$

851

857

852

853

$\begin{array}{lll}854 & 855 & 856\end{array}$

1780 9999ed

859

$\begin{array}{lll}882 & 1308 & 1318\end{array}$

Schatz, J.F.

447

1551

Schechter, B.

$1177 f$

Schechter, R.S.

939

Scheffler, W.A.

728

Schelkopf, J.D. 1083

Schertz, W.W.

1759

Schiff, $L$.

448

Schiner, G.R.

Schipper, L.

Schmidt, E.W.

Schmidt, F.W.

Schmidt, G.

Schmidt, K.D.

Schmisseur, W.E.

Schmitt, R.C.

Schneider, F.N.

Schneider, R.

Schneider, T.R.

Schnurr, N.M.

Schoe 11, G.

1196

1575

1106

1056

1068

449

602

1482 aa

740

244

261

$1315 \mathrm{aa}$

1472

Schoenhals, R.J.

$1383 \mathrm{v}$

Schrefler, B.

Schreiber, D.L.

1708

450

Schreiber, R.E.

1368

Schre iner, F.

1084

Schrock, V.E.

Schroder, J.

Schroeder, R.

Schroeder, R.C.

$1177 i$

879

585

382

1848

732
1002

$963 \quad 1591$

Schubert, $G$.

$1177 \mathrm{ac}$

$1544 k$

Schuler, $T$.

474

1825

Schulte and Koerting Company

938

195

860

1346

Schumacher, M.M.

1824

Schwartz, S.H.

Schwarz, W.J.

Schweitzer, S.

$1177 \mathrm{a} i \mathrm{1177aj}$

Scientific Softwater

681

760

Corporation

Scott Periodicals Corp. $\quad 1409$

$1383 n$

Scott, 0.L.

451

Scott, R.W.

$21 \quad 1758$

1507

$1394401177 a a \quad 1177 a b$

Sebastian, S. 
Seely, E.H.

Segaser, C.S.

Segerstrom, $S$.

Segesman, F.F.

Sepaskhah, A.R.

Seppanen, M.S.

Serata, S.

Serdakov, G.S.

Serth, R.W.

Sevcik, V.J.

Severson, A.M.

Sha, W.T.

Shade, D.J.

Shaffer, C.J.

Shaffer, L.H.

Shamsundar, N.

Shankar, R.

Shannon, L.

Shannon, L.J.

Shannon, R.J.

Shapira, H.G.

Shapiro, L.

Sharp, M.K.

Shaw, D.

Shaw, D.A.

Shaw, D.R.

Shaw, H.

Shay, J.R.

Sheahan, N.T.

Sheely, C.Q.

Sheft, I.

She inbaum, I.

Shelton, J.

Shepherd, J.M.

Sherman, E. 0 .

Shew, D.C.

Shih, T.S.

Shindala, A.

Shippee, D.

Shoepflin, F.

Short, T.H.

Shuck, L.Z.

Siege 1, R.

Sigmon, T.W.

Signhal, A.K.

Signor, D.C.

Sillen, L.G.

Sillman, $S$.

Silverman, H.P.

Silvester, L.F.

Silvestri, $M$.

Silvey, W.D.

Simkin, T.L.

Simmons, D.E.
379

1301

452

1776

880

859

631

435

1018

1051

1107

$1360 \mathrm{q} 1785 \mathrm{bs}$

1053

55

742

$1193 f$

287

1616

$1482 \mathrm{cw}$

1405

1715

1212

933

$1482 \mathrm{u}$

997

1205

1011

785

453

$861 \quad 1781$

$\begin{array}{lll}1084 & 1877 \quad 1878\end{array}$

1535

1422

643

1861

454

1052

271

934

1498

$1315 \mathrm{f}$

632

743

1904 1544c 1383ae

584

56

1463

1362

794

$1177 \mathrm{q}$

1404

1253

$1177 \mathrm{ai}$

$1544 \mathrm{u}$
1720

$1308 \quad 1780$

1122

1274

1521

1612 
Simon, A.D.

Simonpietri, F.

Simpson, E.S.

Simpson, J.P.

455

Sinclair, A.R.

1628

Sinclair, P.J.

269

Singers, $W$.

500

Singh, B.S.

744

Singh, M.M.

745

Singh, S.R.

1598

Singh, $V$.

1824

Sinnott, $A$.

Sitzer, $S$.

Skougstad, M.W.

Slama, 0.

Slege 1, D.L.

Sliwinski, B.J.

Sloan, J.P.

Sloat, B.

Slusser, M.L.

Smerdon, E.T.

Smith, A.J.

Smith, C.C.

Smith, C.G., Jr.

1213

1295

9999df 9999dk

9999bx

880

1052

142

746

687

425

1606

1881

456

457

Smith, C.R.

1107

Smith, G.A.

Smith, G.C.

458

459

Smith, G.S.

Smith, J.E.

Smith, L.

Smith, R.D.

Smith, R.P.

Smith, R.S.

460

1586

$1482 \mathrm{an}$

472

935

Smith, W.F.

1125

Sneddon, I.N.

Sne 11, E.0.

461

905

1385

1503

462

1487

1241

Sniegocki, R.T.

Snoeberger, D.F.

Snyder, R.E.

Solar Energy Research Inst itute

Sol ar Times

1663

Solomon, A.D.

554

713

Solomonov, S.D.

Somerton, C.W.

Somerton, W.H.

Sommerfeld, J.T.

$1193 k$

463

1035

$1215 \quad 1509 \quad 1685$

Soo, S.L.

Sorey, M.L.

Sotgia, G.

Sowe 1 1, E.F.

Sower, F.B.

Spangberg, K.G.

952

Spangler, M.B.

$1785 \mathrm{bs}$

464

1404

$1360 \mathrm{t}$

1371

957

539

$936 \quad 1133$

$1517 \quad 1785$

$747 \quad 1544 i$

$584 \quad 1408 \quad 1177 a q$ 
Sparlin, D.D.

Specken, G.A.

Spencer, D.L.

Spencer, J.F.

$1360 u$

Spencer, R.S.

Spencer, S.G.

Sperry, R.E.

Spillette, A.G.

466

$17781578 \mathrm{fq}$

1053

Spofford, W.A.

Spogen, L.R.

Spotila, J.R.

Springer, T.H.

Spurrier, F.R.

Srinivasan, $R$.

Stacy, J.D.

Stacy, L.E.

Stalkup, F.I.

Stallman, R.W.

Stamper, E.

467

468

1897

Standley, W.R.

Stannard, D.I.

Stark, M.

Staton, B.G.

Stecher, P.G.

Steele, B.L.

Stefan, $H$.

Stepler, R.

Stern, L.I.

Stevenson, W.H.

Steves, H.B.

Stewart, D.

Stewart, J.N., Jr.

Stickford, G.H., Jr.

1482 ap

1039

$1193 f$

$1544 \mathrm{ag}$

863

469

1089

$897 \quad 1214$

$1544 \mathrm{ar}$

1438

470

1812

864

1054

1751

1108

$1582 \mathrm{C}$

1838

1416

300

230

582

1658

Stiles, G.

Stille, H.

328

Stilwell, W.B.

Stine, W.B.

471

1069

Stocker, J.

Stoker, R.C.

Stokes, K.J.

Stott lemyre, J.A.

Stough, M.J.

Stout, N.D.

526

1455

1007

458

$1582 m$ 1383aw 1582ae

608

1475

473

865

474

748

1626

1588

475

470

1240

1814

1214

Strange, L.K.

Straus, J.M.

Strawn, J.A.

Street, R.L.

Streltsova, T.D.

Strisower, B.

Stuermer, D.H. 
Stunic, Z.

Stymne, $H$.

Styris, D.L.

Su, H.J.

Subcasky, W.J.

Sudol, G.A.

Suemoto, S.H.

Suffern, J.S.

Sugama, T.

Sugawara, A.

Suginohara, Y.

Sugisaki, R.

Sulam, D.J.

Sullivan, D.

Sulzber ger, V.T.

1849

1650

572

$1177 \mathrm{aq}$

477

867

318

1229

293

1262

540

478

1427

1055

261

479

483

1395

$1453 n$

578

1101

1284

1346

326

1392

1479

1593

485

1112

868

1519

1746

1909

1645

1056

925

550

TRW, Energy System Planning Division

Taft, G.

Takasaki, K.J.

Talaat, M.E.

Talash, A.W.

Talmage, S.S.

Talwar, R.

Tam, S.W.

Tanaka, T.

Tanayeva, S.A.

Tang, D.H.

Tani, $T$.

Tanji, K.K.

Tank, R.W.

Tardiff, G.E.

Tarman, D.W.

Tarver, G.R.
1025

1216

1853

865

577

$1315 \mathrm{ab}$

1440

1858

749

1763

1858

153

884

959

$1177 n$

1173
1849

$1109 \quad 1449$

294

$579 \quad 580$

$480 \quad 481 \quad 482$

484

1536

$1285 \quad 1286$

604

1294

$1019 \quad 1788 \quad 1900$ 
Task Force 11

1530

Task Force $5 a$

1532

Taube, $M$.

1810

Taunton, J.W.

Tavener, G.F.

Tawhai, J.

471

Taylor, $\mathrm{K}$.

576

Taylor, 0.J.

1217

Taylor-Beard, J. $\quad 1552$

Teggers, J.

1823

Tek, M.R.

Teledyne Brown Engineering,

1128 System Division

Telkes, M.

Teplyakov, D.I.

Ternes, M.P.

Terratek

Terry, J.E.

Tester, J.W.

Tewari, S.C.L.

Texas Energy and Minerà 1 Resources

The Engineering Foundation $\quad 1127$

The Trane Company 1636

The is, C.V.

Thomas, C.R.

Thomas, E.C.

Thomas, H.E.

Thomas, J.F.

Thomas, W.E.

Thompson, G.A.

Thompson, G.M.

Thoms, R.L.

Thomson, W.B.

Thorste insson, $T$.

Thurman, E.M.

Tiedemann, J.B.

Tilton, B.E.

Timmerman, R.W.

Tinker, G.E.

1259

243

$1544 \mathrm{~g}$

965

1218

618

1104

16

$708 \quad 729$

$1854 \quad 1855$

$1544 h$

1636
490

712

758

492

118

651

494

1658

$1582 \mathrm{aa}$

1482 ap

495

$9999 \mathrm{cW}$

544

1730

1058

869

Tinsley, J.M.

Tison, R.R.

Tleimat, B.W.

Todd, D.K.

Tolivia M, E.

Tolley, G.S.

Tolman, C.F.

Toml inson, L.M.

Toney, S.

$\begin{array}{llll}1637 & 1638 & 1639 & 1640\end{array}$

491

$493 \quad 1219$

940

1112

11770

358

496

1890

497

439

1053

Topouzian, A.

Toronyi, R.M.

Tortorelii, P.F.

1850

941

Tostengard, S.

Toth, W.J.

1294

$\begin{array}{lllll}359 & 360 & 361 & 567 & 574\end{array}$


Touhill, C.J.

Tour in, R.H.

Townsend, S.J.

Tramme 1, B.C.

Trantham, J.C.

Trescott, P.C.

Treseder, R.S.

Trezek, G.J.

Triegel, E.K.

Trimborn, P.

Troise, F.L.

Truesde 11, A.H.

Try Agricultural Research Service

Tsang, C.F.

Tsang, Y.W.

Tsao, K.

Tsuchiya, K.

Tull, R.H.

Turcan, A.N.

Turchaninov, I.A.

Turner, F.B.

Turner, M.J.

Turner, R.D.

Turner, R.H.

Twardoch, U.M.

Tye, R.P.

U.S. Congress, Office of Technology Assessment

U.S. Department of Energy, Assistant Secretary for Conservation and Solar Energy

U.S. Department of Energy

U.S. Department of Energy and NASA Lewis Research Center

U.S. Department of Energy, Argonne National Lab, and Univ. of $17 l$ inois-Chicago Circle

U.S. Department of Energy, Assistant Secretary for Energy Technology

U.S. Department of Energy, Asst Secr for Energy Technology and Asst $\mathrm{Secr}$ for Environment

U.S. Department of Energy, Division of Energy Storage Systems
1021

$1453 d$

751

1291

870

1452

498

394

1391

1797

1618

499

1258

500

$\begin{array}{llllll}322 & 501 & 502 & 503 & 504 & 551\end{array}$

$\begin{array}{llllll}552 & 598 & 1184 & 1197 & 1242 & 1354\end{array}$

$\begin{array}{llllll}1527 & 1534 & 1595 & 1602 & 1603 & 1604\end{array}$

$\begin{array}{llllll}1649 & 1672 & 1717 & 1911 & 1177 y & 1582 p\end{array}$

1177ag 1177ak 1177al 1383at 9999r

1534

1389

1862

505

506

1796

756

1866

1856

1157

1544 a a

1857

769

1322

1174

$1326 \quad 1327$

1383

1470

1571

1220

1738

( 
U.S. Department of Energy,

1374

Division of Solar

Applications

U.S. Department of Energy,

Electric Power Research

Inst. and Pacific NW Lab., Battel le

U.S. Department of Energy,

Office of Advanced

Con servation Technologies

Branch, Thermal and

Chemical Storage Br.

U.S. Department of Energy,

Office of Program

Management Support

U.S. Department of Energy, Richland Operations office

U.S. Department of Energy, Technical Information Center

U.S. Dept. of Energy, Asst. Secr. for Energy Tech., Div. of Geothermal Energy

U.S. Dept. of Energy, Office of Industrial Applications and Commercialization

U.S. Dept. of Energy, U.S. Dept. of Housing and Urban Dev. and Int'l District Heating Assn.

U.S. Energy Research and Development Administration

U.S. Energy Research and Development Administration and Electric Power Research Institute

U.S. Energy Research and Development Administration, Division of Building and Industry

U.S. Energy Research and Deve lopment Administration, Division of Solar Energy

U.S. Energy Research and Deve lopment Administration, International Activities

U.S. Environmental Protection Agency

U.S. Environmental Protection Agency and National Water Well Association 


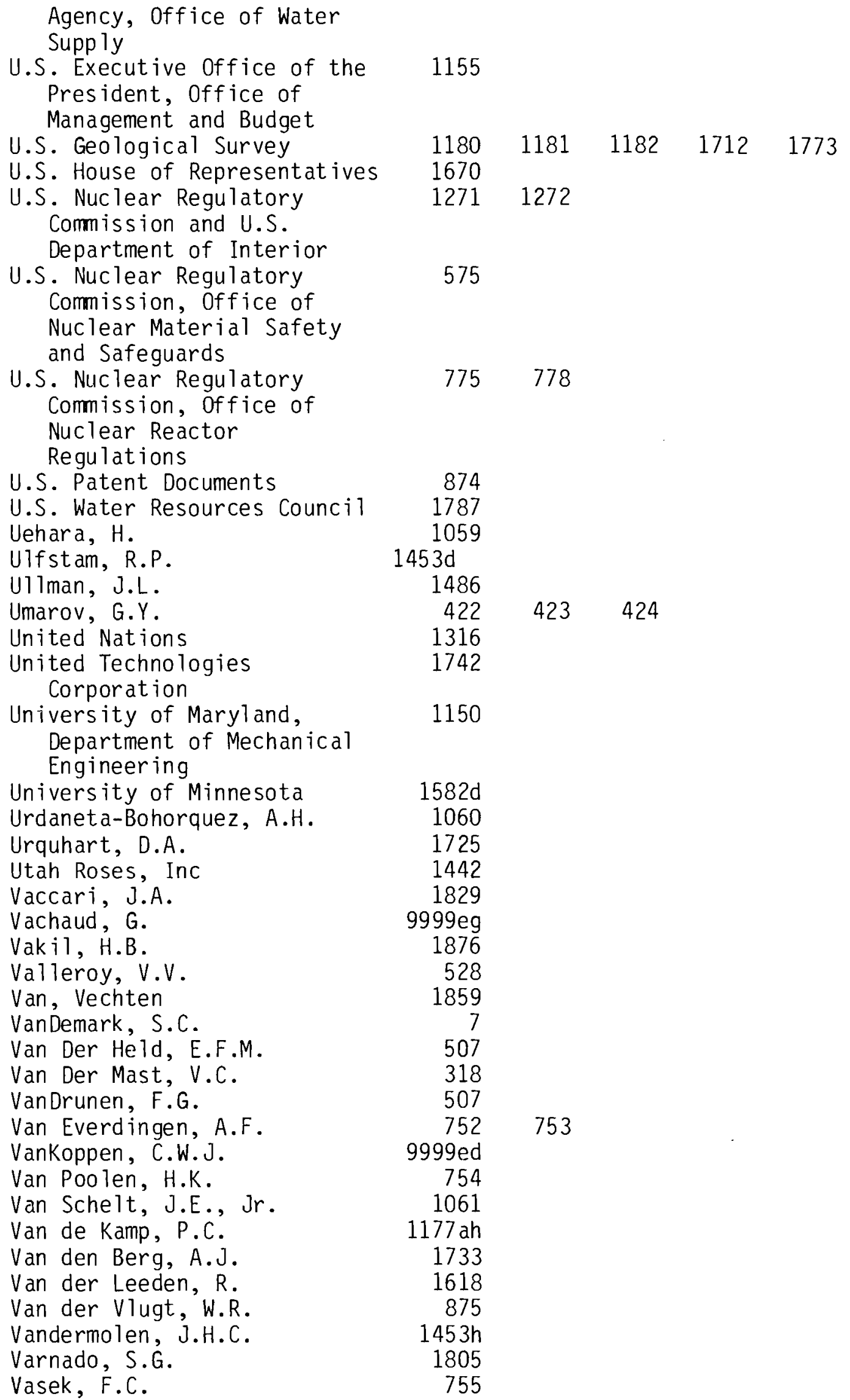


Vecchioli, J.

Veith, K.F.

Veith, R.J.

Venkatesetty, H.V.

Verma, A.

Vernon, R.0.

Versaw, S.F.

Vetter, 0.J.

Veyo, S.E.

Veziroglu, T.N.

Vidali, $M$.

Vides, $A$.

Vieth, G.L.

Villas, R.N.

Viskanta, R.

Vitro Engineering Corporation and Pacific Northwest

Laboratory, Battelle

Volek, C.W.

Vollmar, A.T.

Von Karman Institute for Fluid Dynamics

Von Fuchs, $G$.

Von der Haar, $S$.

Vosburgh, K.S.

Vrable, D.L.

Wachte 11, G.P.

Wade, D.W.

Wade, W.H.

Wagner, $J$.

Wagner, O.R.

Wah 1, E.

Waldschmidt, W.A.

Walker, D.H.

Walker, M.J.

Walker, W.R.

Wall, J.R.

Wallace, G.G.

Wallick, G.C.

Walling, F.B.

Walter, R.A.

Walters, K.L.

Walton, W.C.

Wang, J.S.Y.

Wapora Inc

Ward, J.C.

Warman, $J$.

Warman, J.C.

Warner, D.L.

Warnvist, B.

Warren, J.P.

Warren, R.B.

Washburn, D.C., Jr.

Washington (State)
1427

719

$1544 u$

1111

1860

1420

1696

508

623

1201

1375

105

982

1462

1548

1661

64

756

1669

$1360 \mathrm{v}$

510

689

1097

1724

1291

939

526

872

1425

548

1314

508

231

1161

1467

757

1298

1390

1221

873

1387

1367

511

369

370

514

1463

217

1866

709
$1831 \quad 1838 \quad 1193 c$

1683

1861

$508 \quad 549 \quad 1365$

527

1365

$614 \quad 773 \quad 1546$ $\begin{array}{rrrrr}371 & 512 & 513 & 626 & 1307\end{array}$

$1335 \quad 1366 \quad 1369$ 


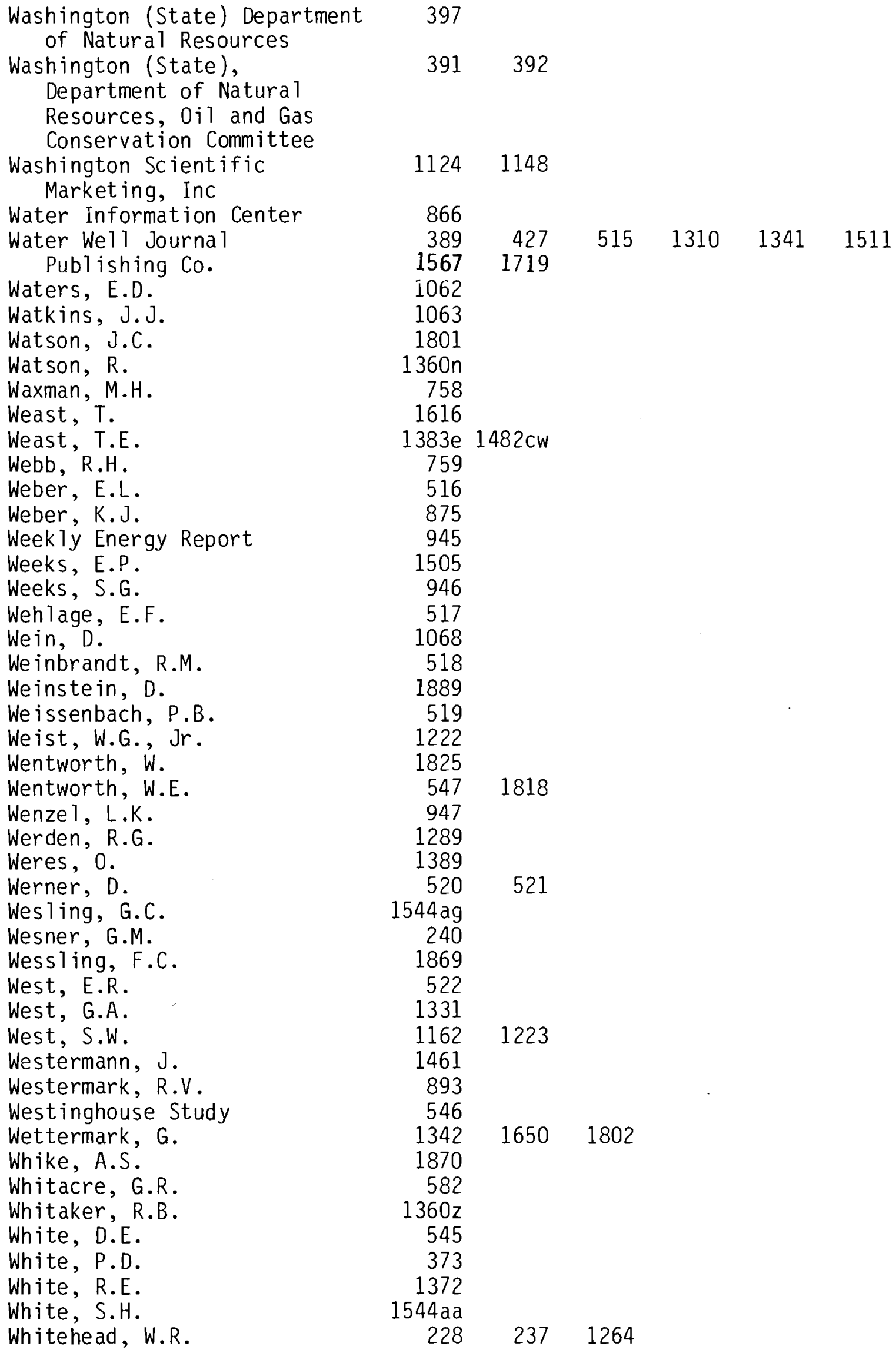


Whitsett, R.M.

Wickersham, G.

Wieland, R.

Wilder Construction Co., Inc.

Wilder, E.W.

Wilen, $P$.

Wiles, L.E.

Wiley, B.F.

Wilhite, C.P.

Wilkinson, B.W.

Willhite, G.P.

Williams, B.J.

Williams, C.E.

Williams, D.A.

Williams, D.L.

Williams, G.T.

Williams, J.D.

Williams, J.R., Jr.

Williams, 0.M.

Williams, R.E.

Williams, T.A.

Williams, T.E.

Williamson, J.W.

Willingham, R.C.

Willis, H.R.

Willman, B.T.

Wilson, J.L.

Wilson, $K$.

Wilson, M.R.

Wilt, M.

Wilt, M.J.

Wingquist, C.F.

Winn, C.B.

Winslow, A.G.

Wintz, W.A.

Wiscons in State Energy Office

Wise, F.A.

Witherspoon, $P$.

Witherspoon, P.A.

Wittenberg, L.J.

Wittenburg, L.J.

Wojnar, F.

Wojtowicz, $A$.

Wolfe, E.J.

Wollenberg, $H$.

Woll lenberg, H.A.

Wong, $L$.

Wood, B.

Wood, L.A.

Wood, W.W.

Wooding, R.A.
884

523

498

949

$1315 \mathrm{w}$

1572

458

1203

885

466

524

1781

1760

544

545

1648

147

940

1816

1411

1346

948

$1315 \mathrm{aa}$

1064

842

528

1757

950

1608

470

609

763

257

529

952

$9999 \mathrm{dw}$

809

443

321

440

1197

1177 ae

1885

1790

1026

1122

1065

470

530

$1177 \mathrm{aq}$

1389

1684

1536 9999di 9999ca

534

1863

$1761 \quad 1762$

$1817 \quad 1819$

11771

13151

1684

1177 af $1177 \mathrm{ak}$

$1315 r$

$535 \quad 536$ $\begin{array}{lll}525 & 526 & 527\end{array}$

$\begin{array}{lllll}322 & 383 & 384 & 385 & 386\end{array}$

$\begin{array}{lllll}504 & 530 & 531 & 533 & 876\end{array}$

$\begin{array}{lllll}1242 & 1387 & 1595 & 1623 & 1177 \mathrm{ac}\end{array}$

532 1177h 1177ae

537

538

621 
Woods ide, W.

1682

Wooley, G.R.

Wouters, L.F.

Wright, J.D.

Wright, M.K.

Wyatt, D.D.

Wyllie, M.R.J.

Wyman, C.E.

Yamsaki, T.

Yanagase, $K$.

Yanagase, $\mathrm{T}$.

Yang, K.T.

Yee, W.C.

Yeh, G.T.

Yeh, $H$.

Yeh, L.T.

Yen, I.

Yeoman, J.C.

Yoshizawa, Y.

Young, J.K.

Young, K.L.

Young, R.J.

Yow, M.G.

Yuan, S.W.

Yudow, B.D.

Zakhidov, R.A.

Zaloudek, F.R.

Zanders, D.L.

Zaquine, M.F.

Zarnoch, K.P.

Zaworski, R.J.

Zebib, A.

Zeldin, A.

Zemkoski, J.

Zenone, $C$.

Zerzan, J.M.

Zhakhidov, R.A.

Zimmerman, C.W.

Zimmerman, W.F.

Zoback, M.D.

Zoega, J.

Zohdy, A.A.R.

Zuck, J.C.

Zur awski, A.

Zygielbaum, P.Z.
402

270

1446

1039

1901

539

1446

$1579 \mathrm{bu}$

540

540

$1315 \mathrm{~s}$

1066

1627

1094

1826

1425

$1453 \mathrm{~m}$

1262

$1582 \mathrm{u}$

764

$972 \quad 973$

1335

541

1112

422

$1582 \mathrm{u}$

1122

78

$1383 y$

572

220

293

579

1224

367

424

150

$1544 \mathrm{ag}$

542

245

1386

1320

1225

706

580
$15431544 p$

154315440

$\begin{array}{lll}543 & 765 & 1827\end{array}$

$1109 \quad 1449$

294

$4401177 \mathrm{ac}$ 
IDENTIFICATION NUMBER INDEX 
1 Abrams, A.

2 Ackerman, T.V. and E.J. Lynde.

3 Adams, R.H. and A.M. Khan.

4. Alavian, V.

5 Allegrini, G. and G. Benvenuti.

6 Allison, L.E.

7 Alpert, J.E., S.C. VanDemark, D.D. Fritton, and D.R. DeWalle.

8 Ambrose, E.R.

9 Ambrose, E.R.

10 American Petroleum Institute.

11 Anderson, J.H.

12 Anderson, K. and J.E. Kelly.

13 Andrews, C.B.

14 Andrews, C.B. and M.P. Anderson.

15 Andrews, C.B. and M.P. Anderson.

16 Texas Energy and Mineral Resources.

17 Appe 1, C.A., and J.D. Bredehoef L.

18 Aruna, M., N. Arihara, and H.J. Ramey, Jr.

19 Axtmann, R.C.

20 Aziz, K., S.A. Bories, and M.A. Combarnous.

Balashov, L.S.

Balke, K.D.

Banks, H.O.

Barnes, B.A. and P. Livingston.

Beck, J.L.

Beers, T.S.

Benson, S.M., C.B. Gor anson, J.P. Haney, and R.C. Schroeder. Bernard, W.J.

Birtles, A.B. and M.J. Reeves.

Blake, T.R. and S.K. Garg.

Blackwe11, D.D., E. Granados, and J.B. Koenig.

Blakeley, L.E.

Bloomster, C.H., L.L. Fassbender, and C.L. McDonald.

Bodvarsson, $G$.

Bodvarsson, $G$.

Bodvarsson, $G$.

Bodvarsson, $G$.

Bodvarsson, $G$.

Bodvarsson, $G$.

Bodvarsson, $G$.

Bodvarsson, $G$.

Bodvarsson, G. and A. Bjornsson.

Bodvarsson, G. and G.M. Reistad.

Boldizsar, T.

Bolton, P.

Bosazza, V.L.

50

Bostock, C.A., E.S. Simpson, and T.G. Roefs.

51 Bouwer, $H$.

52 Brace, W.F., A.S. Orange, and T.R. Madden. 


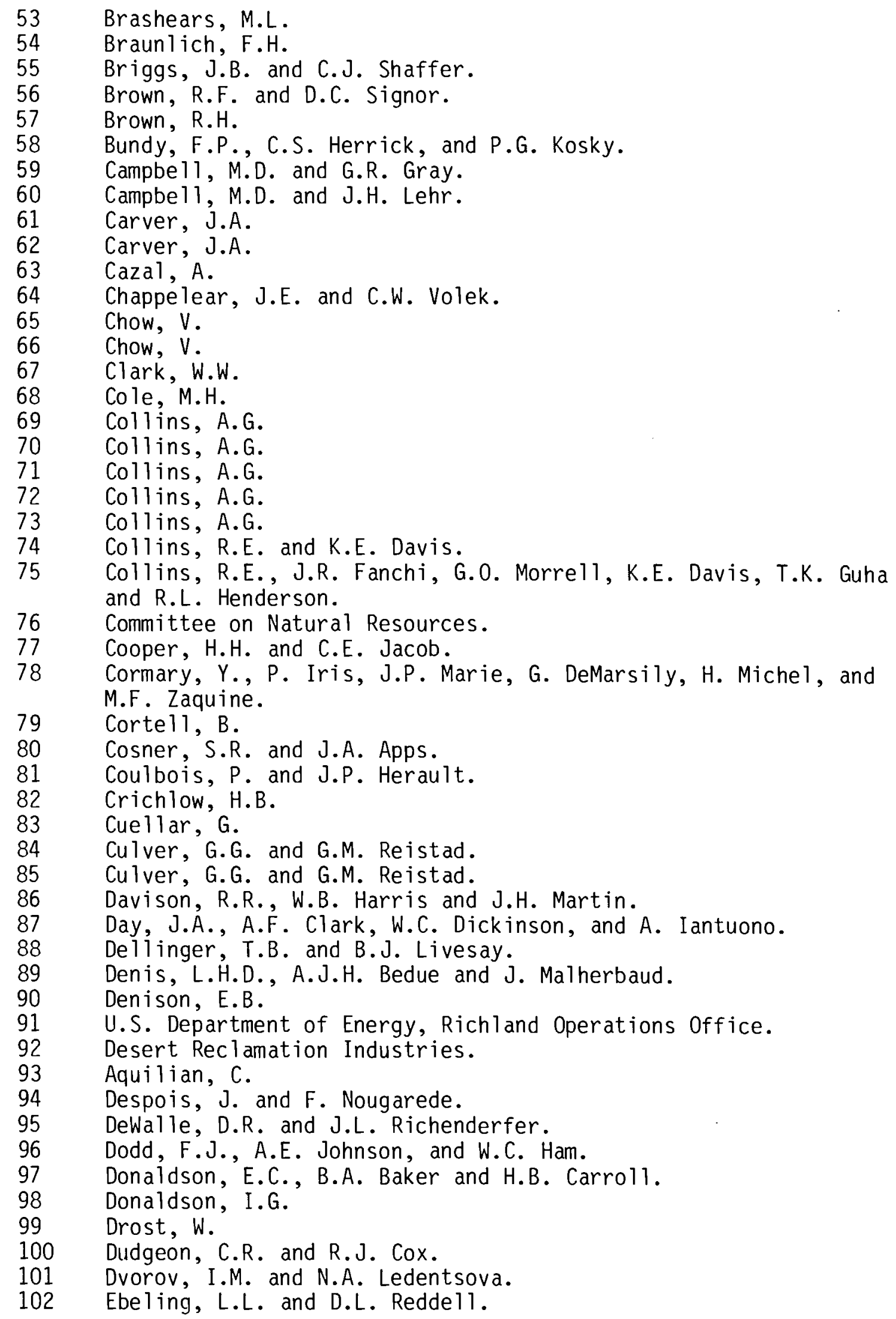


Eckert, A.W.

104 Edwards, A.L.

105 Einarsson, S.S., A. Vides, and G. Cuellar.

106 Ellenberger, F.R., A.B. Hubbard, W.R. Foote, F. Burggraf, J.J. Martin and N.J. Bloomfield.

107 Engen, I.A.

108 Sandia Livermore Laboratory.

109 American Petroleum Institute, Environmental Affairs Department.

110 U.S. Environmental Protection Agency.

111 U.S. Environmental Protection Agency.

112 U.S. Environmental Protection Agency.

113 U.S. Environmental Protection Agency and National Water Well Association.

114 Esmail, 0.J. and O.K. Kimbler.

115 Faust, C.R. and J.W. Mercer.

116 Fenske, P.R.

117 Fenske, P.R.

118 Fox, E.C. and J.F. Thomas.

119 Fulford, R.S.

120 Gabrysch, R.K. and C.W. Bonnet.

121 Gambolati, G.

122 Gannon, R.

123 Gass, T.E.

124 Gass, T.E.

125 Gass, T.E.

126 Gass, T.E.

127 Gass, T.E.

128 Gass, T.E. and J.H. Lehr.

129 Gass, T.E. and J.H. Lehr.

130 Gates, C.F. and B.G. Holmes.

131 Geertsma, J.

132 Washington (State).

133 Gibb, J.P. and E.W. Sanderson.

134 Gill, M.A.

135 Givoni, B.

136 Gleason, V.E.

137 Glover, R.E. and W.T. Moody.

138 Goranson, C.B. and R.C. Schroeder.

139 Goranson, C.B., R.C. Schroeder, and J.P. Haney.

140 Goyal, K.P. and D.R. Kassoy.

141 Goyal, K.P. and D.R. Kassoy.

142. Grantham, C.K. and J.P. Sloan.

143 Gray, G.R.

144 Gray, W.G. and K. O'Neill.

145 Gregg, D.O. and K.G. Kennedy.

146 Green, D.W.

147 Green, M.A., H.S. Pines, W.L. Pope, and J.D. Williams.

148 Gringarten, A.C. and J.P. Sauty.

149 Gringarten, A.C. and J.P. Sauty.

150 Guest, R.J. and C.W. Zimmerman.

151 Guha, T.K., K.E. Davis, R.E. Collins, J.R. S Fanchi and A.C. Meyers. 
152 U.S. Environmental Protection Agency.

153 Gupta, S.K., K.K. Tanji, and J.N. Luthin.

154 Hadley, W.A. and R. Eisenstadt.

155 Halevy, E. and $A$. Nir.

156 Hanck, J.A. and G. Nekoksa.

157 Hansen, V.E.

158 Hantush, M.S.

159 Hantush, M.S.

160 Hantush, M.S. and C.E. Jacob.

161 Hantush, M.S. and C.E. Jacob.

162 Hantush, M.S. and C.E. Jacob.

163 Harnish, J.R.

164 Hausz, $W$.

165 Hausz, $W$.

166 Hausz, $W$.

167 Hausz, $W$.

168 Hausz, $W$.

169 Hausz, $W$.

170 Hausz, W., B.J. Berkowitz and R.C. Hare.

172 Hausz, W. and C.F. Meyer.

173 Hausz, W. and C.F. Meyer.

174 Building Research and Practice.

175 Electrical World.

176 Air Conditioning, Heating and Ventilating.

177 Hegelson, H.C. and D.H. Kirkham.

178 Heiss, H.W.

179 Hellstrom, G.

180 Helweg, 0.J.

181 Henry, H.R., J.R. McDonald, and R.M. Alverson.

182 Hermannsson, S.

183 Hewitt, C.H.

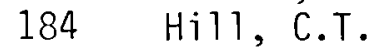

185 Hoeppner, S.

186 Hoffman, H.W.

187 Hoffman, H.W., S.K. Fraley and R.J. Kedl. (Compilers).

188 Holton, W.C.

189 Holzschuh, J.C.

190 Horton, C.W. and F.T. Rogers.

191 Horvath, E. and G.H. Elkan.

192 Ground Water Age.

193 Howard, J.

194 Petroleum Engineer.

195 Huber, H.D., C.L. McDonald, C.H. Bloomster, and S.C. Schulte.

196 Huyakorn, P.S. and C.R. Dudgeon.

197 Public Works.

198 Ineson, J.

199 Intercomp Resource Development and Engineering, Inc.

200 U.S. Energy Research and Development Administration, International Activities.

201 Jacob, C.E.

202 Jacob, C.E.

203 Jacob, C.E. 


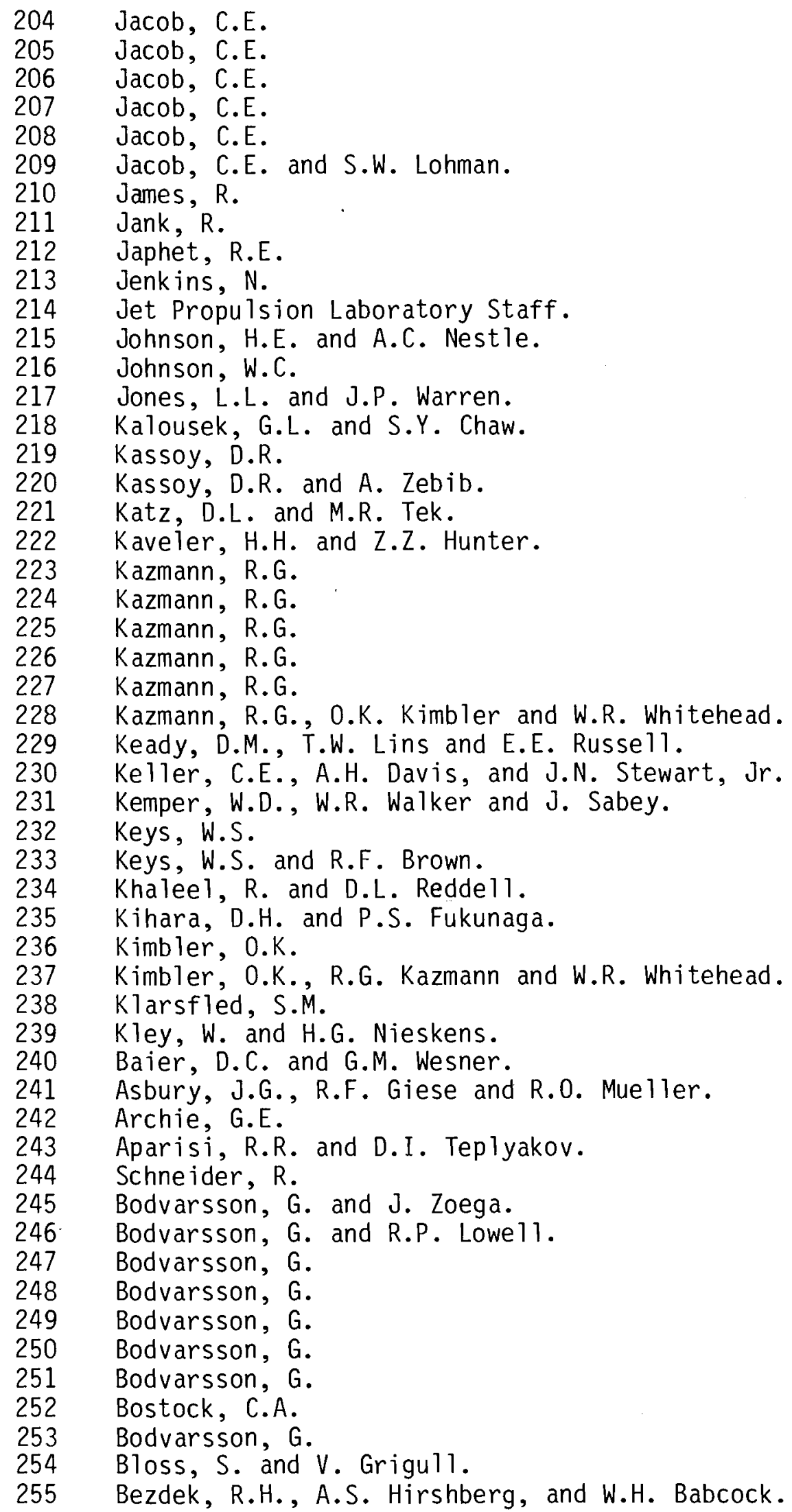


Birtles, A.B. and M.J. Reeves. 
306 Lawrence Berkeley Laboratory, Earth Sciences Division.

307 Lawrence Berkeley Laboratory, Earth Sciences Division.

308 Lawrence Berkeley Laboratory, Earth Sciences Division.

309 Lefebre, $V$.

310 Leggette, R.M. and M.L. Brashears.

311 Lehr, J.H.

312 Lehr, J.H.

313 Lenzer, R.C., G.W. Crosby, and C.W. Berge.

314 Lesem, L.B., F. Greytok, F. Marotta, and J.J. McKetta.

315 Li, W.H.

316 Lienau, P.J.

317 Lienau, P.J. and J.W. Lund.

318 Lindemuth, T.E., E.H. Houle, S.H. Suemoto, and V.C. Van Der Mast

319 Lindorff, D.E.

320 Lippmann, M.J.

321 Lippmann, M.J., T.N. Narasimhan, and P.A. Witherspoon.

322

323

324

325

326

Lippmann, M.J., C.F. Tsang, and P.A. Witherspoon.

Louden, L.R. and R.E. McGlothlin.

Loy, S.E.

Lund, J.W.

Lund, J.W., G.G. Culver, S. Doyle, P.J. Lienau, A. Rathmacher, and L.S. Svanevik.

327 Lund, J.W., P.J. Lienau, G.G. Culver, and C.V. Higbee.

328 Lundstrom, L. and $H$. Stille.

329 Lynch, E.J. and E.A. Breitenbach.

330 Maddock, T.

331 Madhav, M.R. and P. Basak.

332 Edward E. Johnson, Inc.

333

334

335

336

337

338

339

Marx, J.W. and R.H. Langenheim.

Mathey, B.

Mathey, B.

Mathey, B. and A. Menjoz.

McCune, C.C.

McDonald, C.L. and C.H. Bloomster.

McFarland, C.R.

McLean, G.0.

McNabb, J.F. and W.J. Dunlap.

Megley, J.W.

Megley, J.W. and G.W. McElhaney.

Meinzer, 0.E.

Mercer, J.W., G.F. Pinder and I.G. Donaldson.

McCain, W.D. and J.D. Stacy.

Meyer, A.F.

Meyer, C.F.

Meyer, C.F.

Meyer, C.F.

Meyer, C.F.

Meyer, C.F.

356 Meyer, C.F. and W. Hausz. 
357 Meyer, C.F., W. Hausz, B.L. Ayres and H.M. Ingram.

358 Meyer, C.F. and D.K. Todd.

359 Meyer, C.F. and D.K. Todd.

360 Meyer, C.F. and D.K. Todd.

361 Meyer, C.F., D.K. Todd and R.C. Hare.

362 Meyer, W.R.

363 Meyer, C.F., and W. Hausz.

364 Michaels, A.I.

365 Milburn, H.L.

366 Miller, C.W.

367 Miller, C.W. and J.M. Zerzan.

368

369

370

371

372

373

374

375

376

377

378

379

380

381

382

383

384

385

386

387

388

389

390

391

392

393

394

395

396

397

398

399

400

401

402

403

Molz, F.J. and L.C. Bell.

Molz, F.J. and J. Warman.

Molz, F.J., J.C. Warman and T.E. Jones.

Molz, F.J., J.C. Warman, T.E. Jones and G.E. Cook.

Morey, G.W., R.0. Fournier and J.J. Rowe.

Moss, J.T. and P.D. White.

Moulder, E.A.

Mount, J.R.

Mungan, N.

Murphy, H.D.

Mylander, H.A.

Naney, J.W., D.C. Kent and E.H. Seely.

Narasimhan, T.N.

Narasimhan, T.N.

Narasimhan, T., R. Schroeder, C.G. Goranson, D. McEdwards, D. Campbel1, and J.H. Barkman.

Narasimhan, T.N. and P.A. Witherspoon.

Narasimhan, T.N. and P.A. Witherspoon.

Narasimhan, T.N. and P.A. Witherspoon.

Narasimhan, T.N. and P.A. Witherspoon.

Neuman, S.P. and T.N. Narasimhan.

Newman, M.E.

Water Well Journal Publishing Co.

Obbink, J.G.

Washington (State), Department of Natural Resources, $0 i 1$ and Gas Conservation Committee.

Washington (State), Department of Natural Resources, $0 i 1$ and Gas Conservation Committee.

0liker, I.

01szewski, M. and G.J. Trezek.

Oster, C.A.

Ozawa, T. and J. Fujii.

Washington (State), Department of Natural Resources.

National Research Council, U.S. National Committe for Rock

Mechanics, Energy Resource Recovery Dev.

Papadopulos, S.S. and S.P. Larson.

Pasquifer, $F$.

Penrod, E.B.

Perkins, T.K., G.R. Wooley, and F.W. Ng.

404 Peterson, J.S., C. Rohwer, and M.L. Albertson. 
Pettitt, R.A. Pettitt, R.A. Pettitt, R.A. Pettitt, R.A. Pettitt, R.A. Pettyjohn, W.A. Phillips, S.L., A.K. Mathur, and R.E. Doebler. Pinder, G.F.

Piper, A.M.

Pitt, W.A. Jr., F.W. Meyer, and J.E. Hull.

Plummer, K.H. and T.M. Rachford.

Poland, J.F. and G.H. Davis.

Poland, J.F. and J.H. Green.

Poland, J.F. and G.H. Davis.

Pope, W.L., H.S. Pines, R.L. Fulton, and P.A. Doyle.

Qvale, E.B.

Qvale, E.B.

Rabbimov, R.T., G.Y. Umarov and R.A. Zakhidov.

Rabbimov, R.T., G.Y. Umarov and R.A. Zakhidov.

Rabbimov, R.T., R.A. Zhakhidov and G.Y. Umarov.

Rahman, M.A., E.T. Smerdon, and E.A. Hiler.

Ramey, H.J., Jr.

Water Well Journal Publishing Co.

Reed, M.G.

Ridgeway, S.L., and J.L. Dooley.

Roache, P.J. and T.S. Mueller.

Robeck, G.G.

Robichaux, J.

Romagnoli, P., G. Cuellar, M. Jimenez, and G. Ghezzi.

Romero, J.C.

Rozenfeld, L.M. and G.S. Serdakov.

Rubin, $H$.

Rubinshtein, L.I.

Rushton, K.R. and Y.K. Chan.

Rushton, K.R. and L.M. Toml inson.

Pruess, K., J.M. Zerzan, R.C. Schroeder and P.A. Witherspoon.

Price, D., D.H. Hart, and B.L. Foxworthy.

Price, M.

Pruess, K., G. Bodvarsson, R. Schroeder, P. Witherspoon, R.

Marconcini, G. Neri, and C. Ruffilli.

Saffman, P.G.

Salieva, R.B. and R.P. Saliev.

Saltzman, B. and J.A. Pollack.

Schafer, D.C.

Schiff, L. and K.L. Dyer.

Schmidt, K.D.

Schreiber, D.L., A.E. Reisenauer, K.L. Kipp, and R.T. Jaske. Scott, R.W. Segerstrom, S. Sheahan, N.T.

Shew, D.C. and J.W. Keeley.

Simpson, J.P. 
Smith, C.G., Jr. and J.S. Hanor.

457 Smith, C.R. and S.J. Pirson.

458 Smith, G.C., J.A. Stottlemyre, L.E. Wiles, W.V. Loscutoff, and H.J. Pincus.

459 Smith, G.S.

460 Smith, J.E.

461 Sneddon, I.N.

462 Snyder, R.E.

463 Somerton, W.H., and S. El-Hadidi.

464 Sorey, M.L.

465 Specken, G.A.

466 Spencer, R.S., W.S. Butler, M.K. Enns and B.W. Wilkinson.

467 Spillette, A.G.

468 Spofford, W.A.

469 Stallman, R.W.

470 Stark, M., N. Goldstein, H. Wollenberg, B. Strisower, H. Hege, and M. Wilt.

471 Stilwell, W.B., W.K. Hall, and J. Tawhai.

472 Stottlemyre, J.A., R.P. Smith, and R.L. Erikson.

473

474

475

476

477

478

Stracke, K.J., D.C. Mason, and R.G. Altman.

Straus, J.M. and G. Schubert.

Streltsova, T.D. and K.R. Rushton.

Oak Ridge National Laboratory.

Subcasky, W.J.

Sugisaki, R.

Suman, G.0. Jr. and R.C. Ellis.

Suman, G.0. Jr. and R.C. Ellis.

481 Suman, G.0. Jr. and R.C. Ellis.

482 Suman, G.0. Jr. and R.C. Ellis.

483 Sumner, J.A.

484 Sumner, J.A.

485 Swartzendruber, D.

486 National Association of Corrosion Engineers, Technical Practices Committee.

487 National Association of Corrosion Engineers, Technical Practices Committee.

488 National Association of Corrosion Engineers, Technical Practices Committee.

489 National Association of Corrosion Engineers, Technical Unit Committee.

490 Theis, C.V.

491 Theis, C.V.

492 Thomas, H.E.

493 Thomas, H.E.

494 Thompson, G.A. and D.B. Burke.

495 Thorsteinsson, $T$.

496 Tolivia, M.E.

497 Tolman, C.F. and J.F. Poland.

498 Treseder, R.S. and R. Wiel and.

499 Truesdell, A.H.

500 Truesdel1, A.H. and W. Singers.

501 Tsang, C.F. 
502 Tsang, C.F., P. Fong, C.W. Miller and M.J. Lippmann.

503 Tsang, C.F. and M.J. Lippmann.

504 Tsang, C.F., M.J. Lippmann, C.B. Goranson, and P.A. Witherspoon.

505 Tull, R.H.

506 Turcan, A.N.

507 Van Der Held, E.F.M. and F.G. VanDrunen.

508 Vetter, 0.J., D.A. Campbe11, and M.J. Walker.

509 Vetter, 0.J. and R.C. Phillips.

510 Vonder Haar, S. and I.P. Cruz.

511 Ward, J.C.

512 Warman, J.C., F.J. Molz and T.E. Jones.

513 Warman, J.C., F.J. Molz and T.E. Jones.

514 Warner, D.L. and J.H. Lehr.

515 Water Well Journal Publishing Co.

516 Weber, E.L.

517 Wehlage, E.F.

518 Weinbrandt, R.M., H.J. Ramey Jr. and F.J. Casse.

519 Weissenbach, P.B.

520 Werner, D. and K.D. Balke.

521 Werner, D. and W. Kley.

522 West, E.R.

523 Wickersham, G.

524 Willhite, G.P.

525 Willhite, G.P. and W.K. Dietrich.

526

527

528

529

530 Witherspoon, P.A., H.A. Espinosa, M.J. Lippmann, A.M. Mercado

Willhite, G.P., J. Wagner, F. Simonpietri and J. Stocker.

Willhite, G.P. and J. Wagner.

Willman, B.T., V.V. Valleroy, G.W. Runberg, A.J. Cornelius, and L.W. Powers. and H.A. Wollenberg.

531 Witherspoon, P.A. and J.A. Apps.

Woll lenberg, H.A., R.E. Bowen, H.R. Bowman, and B. Strisower.

533

534

535

536

537

Witherspoon, P.A. and 0. Degerman.

Wooding, R.A.

Wooding, R.A.

Wooding, R.A.

Wooding, R.A.

538

539

540

541

542

543

544

545

546

547

Wooding, R.A. and H.J. Morel-Seytoux.

Wyllie, M.R.J. and M.B. Spangler.

Yanagase, T., Y. Suginohara, and K. Yanagase.

Yuan, S.W., A.M. Bloom, and M. Nazli.

Zoback, M.D. and J.S. Byerlee.

Yuan, S.W., A.M. Bloom, and M. Nazli.

Williams, D.A. and J.B. Tiedemann.

White, D.E. and D.L. Williams. (eds).

Westinghouse Study.

Wentworth, W.E. and E. Chen.

548 Waldschmidt, W.A.

549 Vetter, 0.J. and D.A. Campbel1.

550 TRW, Energy System Planning Division.

551 Tsang, C.F. 
552 Tsang, C.F.

553 Stottlemyre, J.A., R.A. Craig, W.V. Loscutoff, D.W. Boehm, and G.C. Chang.

554 Solomon, A.D.

555 Nicholls, R.L.

556 Newman, S.P.

557 Moesta, H.

558 National Water Well Association.

559 Narasimhan, T.N.

560 Muffler, L.J.P. (ed).

561 Mueller, R.0., J.G. Asbury, J.V. Caruso, D.W. Connor, and R.F. Giese.

562 Moulder, E.A. and D.R. Frazor.

563 Moses, T.H., Jr. and J.H. Sass.

564 Milora, S.L. and J.W. Jefferson.

565 MilTer, R.E.

566 Millard, V., N.G. Berndtsson, and J.A. Bray.

567 Meyer, C.F. and D.K. Todd.

568 McCaffey, F.G.

569 Mathey, B., E. Recordon, and B. Saugy.

570 Lofgren, B.E.

571 Lofgren, B.E.

572 Leshuk, J.P., R.J. Zaworski, D.L. Styris, and O.K. Harling.

573 Lehr, J.H.

574 Todd, D.K.

575 U.S. Nuclear Regulatory Commission, Office of Nuclear Material Safety and Safeguards.

576 Taylor, K.

577 Talmage, S.S. and C.C. Coutant.

578 Surface, M.0.

579 Sulzberger, V.T. and J. Zemkoski.

580 Sulzberger, V.T. and J. Zemkoski.

581 Streltsova, T.D.

582 Stickford, G.H., Jr., C.F. Holt, and G.R. Whitacre.

583 Powell, W.R.

584 Signhal, A.K., D.P. Mikherjec, and W.H. Somerton.

585 Schroder, J.

586 Ross, P.N.

587 SaTeem, Z.A. and C.E. Jacob.

588 Sarot, J.

589 Roseen, R.

590 Rodriquez-Amaya, C.

591 Poland, J.F.

592 Parker, S.A.

593 King, S. (ed).

594 Miles, C.R.

595 J. Donald Kroeker and Associates.

596 Kreitlow, D.B.

597 Cooley, R.L. and A.B. Cunningham.

598 Tsang, C.F. (translator).

599 Komedera, M.

600 Komedera, M.

601 Andrews, C.B. 
602 Boersma, L., L.R. Davis, G.M. Reistad, J.C. Ringle, and W.E. Schmisseur.

603 Churchi11, D.J.

604 Culver, G.G., J.W. Lund, and L.S. Svanevik.

605 Eggers, D.E.

606 Garza, S.

607 Federal Register.

608 Gillespie, J.B., G.D. Hargadine, and M.J. Stough.

609

610

611

612

613

614

615

616

617

618

619

620

621

622

623

624

625

626

627

628

629

630

Goldstein, N.E., R.A. Norris, and M.J. Wilt.

Hanson, J.M.

Hantush, M.S.

Keenan, J.H. and F.G. Keyes.

Federal Register.

Walker, W.R. and W.E. Cox.

Komedera, M.

Lienau, P.J.

Iris, $P$.

Cummings, R.G., G.E. Morris, J.W. Tester, and R.L. Bivins.

Bureau of National Affairs, Inc.

Allen, R.D.

Wooding, R.A.

Holt, L., R. Jones and G. Hagey.

Kirschbaum, H.S. and S. E. Veyo.

Lienau, P.J. and J.W. Lund.

Kovach, E.G. (ed)

Molz, F.J., A.D. Parr, P.F. Anderson, V.D. Lucido, and J.C.

Warman.

Ramey, H.J., Jr.

Combarnous, M.A. and S.A. Bories.

Oregon Institute of Technology, Geo-heat Utilization Center.

and S.L. Ridgeway.

631 Adachi, T., S. Serata, and S. Sakurai.

632 Advani, S.H., L.Z. Shuck, H.Y. Chang, and H.V. Gangarao.

633 Aktan, T. and S.M. Farouq-Ali.

634 National Association of Corrosion Engineers and American Petroleum Institute.

635 Aziz, K., T. Kaneko, and M.F. Mohtadi.

636 American Society of Heating, Refrigerating, and Air-Conditioning Engineers.

637 American Society of Heating, Refrigerating, and Air-Conditioning Engineers.

638. American Society of Heating, Refrigerating, and Air-Conditioning Engineers.

639 Bailey, J.A., J.C. Mulligan, C.K. Liao, and S.I. Guceri.

640 Bailey, R.G. (compiler).

641 Barbish, A.B. and G.H.F. Gardner.

642 Bass-Becking, L.G.M., I.R. Kapl an and D. Moore.

643 Bell, J.S. and J.M. Shepherd.

644 Bennion, D.W. and M.J. Goss.

645 Boberg, T.C. and R.B. Lantz.

646 Bodvarsson, $G$. 


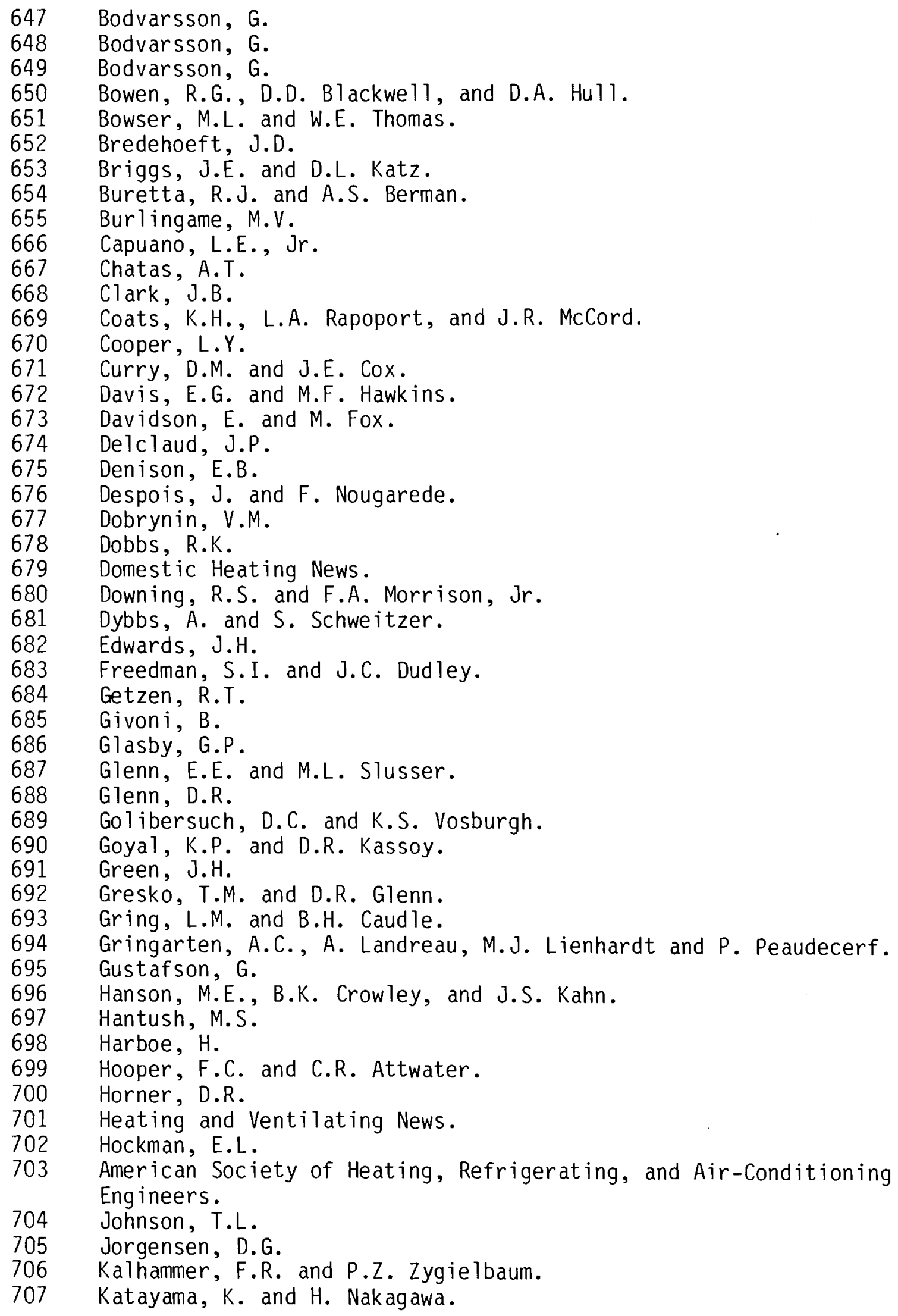


Katz, D.L., M.R. Tek, and S.C. Jones.

Kilgore, L.A. and D.C. Washburn, Jr.

Kilpatrick, F.A.

711 Klinkenberg, L.J.

Koch, R.K., E.D. Calvert, C.R. Thomas, and R.A. Beal1.

713

714

Lidorenko, N.S., G.F. Muchnik, S.D. Solomonov, and A.R. Gordon.

Lindroth, D.P.

715 Konczak, Z.

Lawrence Berkeley Laboratory, Energy and Environment Division.

717

718

Lo, H.Y. and N. Mungan.

Luikov, A.V.

719 Marovel1i, R.L. and K.F. Veith.

720

721

722

723

724

725

726

727

728

729

730

731

732

733

734

735

736

737

738

739

740

741

742

743

744

745

746

747

748

749

750

751

752

753

754

Mather, J.D., D.A. Greenwood, and P.B. Greenwood.

McCuen, R.H. and L.E. Asmussen.

McGaw, R.

American Petroleum Institute.

Minkowycz, W.J. and P. Cheng.

Mueller, T.D.

Nicholls, R.L.

Nolen, J.S. and D.W. Berry.

Oster, C.A. and W.A. Scheffler.

Pandey, G.N., M.R. Tek, and D.L. Katz.

Poland, J.F.

Potter, R.W.

Schneider, R.

Raats, P.A.C.

B\&A Engineers, LTD.

Rogers, F.C. and W.E. Larson.

Santing, G.

Sanyal, S.K. and H.T. Meidav.

Sanya1, S.K., S.S. Marsden, and H.J. Ramey.

Sather, N.F., L.G. Lewis, G.T. Kartsounes, and H.H. Chiu.

Schneider, F.N. and W.W. Owens.

Serata, S.

Shaffer, L.H.

Siege 1, R.

Singh, B.S. and A. Dybbs.

Singh, M.M. and P.J. Huck.

Sloat, $B$.

Solomon, A.D.

Strausberg, S.I.

Tanayeva, S.A.

Taunton, J.W. and E.N. Lightfoot.

Townsend, S.J.

Van Everdingen, A.F. and W. Hurst.

$V$ an Everdingen, A.F.

Van Poolen, H.K.

Vasek, F.C., H.B. Johnson, and D.H. Eslinger.

Vollmar, A.T., B.G. Maza, P.A. Medica, F.B. Turner, and S.A.

Bamberg.

758

Wallick, G.C. and J.S. Aronofsky.

Waxman, M.H. and E.C. Thomas. 
Webb, R.H., H.C. Ragland, W.H. Godwin, and D. Jenkins. Scientific Softwater Corporation. Bental l, J.E. (ed). Blackshear, P.L., P.L. Emerson, B. Rabi-Baliga and M. Riaz. Wingquist, C.F.

Young, K.L.

Yuan, S.W. and L.S. Galowin.

U.S. Department of Energy, Electric Power Research Inst. and Pacific NW Lab., Battelle.

U.S. Department of Energy, Electric Power Research Inst. and Pacific NW Lab., Battelle. Moseley, J.C. and J.F. Malina, Jr. U.S. Congress, Office of Technology Assessment. Robert S. Kerr Environmental Research Laboratory and National Water Well Association.

U.S. Department of Energy, Division of Energy Storage Systems. Carvel1, K.L. and P.A. Johnston. Walker, W.R. and W.E. Cox.

U.S. Environmental Protection Agency, Office of Water Supply. U.S. Nuclear Regulatory Commission, Office of Nuclear Reactor Regulations.

$$
\text { Salk, M.S. and S.G. DeCicco (eds). }
$$

Chalmers, J.A. and E.J. Anderson. U.S. Nuclear Regulatory Commission, Office of Nuclear Reactor Regulations. Lohman, S.W. Centrilift, Inc. Castine 1, G. and M.A. Combarnous. Malofeev, G.E. U.S. Energy Research and Development Administration and Electric Power Research Institute. National Water Well Association. Reistad, G.M., W.E. Schmisseur, J.R. Shay, and J.B. Fitch. (eds) Lienau, P.J. Adkison, J.A. Advisory Council on Historic Preservation. American Gas Association, Committee on Underground Storage. American Petroleum Institute. Asbury, J.G., R.F. Giese, R.O. Mueller and S.H. Nelson. Asbury, J.G., C. Maslowski, and R.0. Mueller. Bayl in, F. Berkowitz, J.B. and H.P. Silverman (eds). Bouwer, H. Brashear, J.P. and V.A. Kuuskraa. Brown, J.S. Brunton, G.D., D.M. Eissenberg, and R.J. Ked1. Carlson, F.M. and C.S. Land. Chakravorty, S.K., P.R. Brown, and N. Endsin. Chang, H.L. Chang, H.L., H.M. Al-Rikabi, and W.H. Pusch. Collie, M.J. (ed). Collie, M.J., (ed). 
805 Connor, D.W. and R.0. Mueller.

806 Connor, D.W. and R.0. Mueller.

807 Culver, G.G.

808 DeRenzo, D.J. (ed).

809 Doscher, T.M. and F.A. Wise.

810 Earlougher, R.C.

811 Eissenberg, D.M. and H.W. Hoffman.

812 Faust, C.R. and J.W. Mercer.

813 Faust, C.R. and J.W. Mercer.

814 Franco, A.

815 Franco, A.

816 Gates, G.L. and C.F. Parent.

817 Geological Society of America.

818 George, C.J. and L.H. Stiles.

819 Cook, T.D. (ed).

820 Havrilak, R.J.

821 Haynes, C.D. and D.M. Grubbs.

822 Herbeck, E.F., R.C. Heintz, and J.R. Hastings.

823 Herbeck, E.F., R.C. Heintz, and J.R. Hastings.

824 Herbeck, E.F., R.C. Heintz, and J.R. Hastings.

825 Herbeck, E.F., R.C. Heintz, and J.R. Hastings.

826 Hill, R.F. (ed).

827 Holman, J.P.

828 Hooper, F.C. and F.R. Lepper.

829 Hooper, F.C.

830 Huxtable, D.D. and D.R. Poole.

831 Jameson, J.S., Jr.

832 Jardine, D.M. and D.W. Jones.

833 Karanjac, J.

834 Keys, W.S.

835 Mercer, J.W. and C.R. Faust.

836 Mulac, A.J., W.L. Flower, R.A. Hi11, and D.P. Aeschliman.

837 Mutti, D.H., J.E. Atwood, C.R. LaFayette, and A.0. Landrum.

838 Noran, D. (ed).

839 Noran, D. (ed).

840 Noran, D.

841 Noyes, R. (ed).

842 O'Brien, L.J., R.S. Cooke, and H.R. Willis.

843 0lszewski, M.

844 Paul, J.K.

845 Prats, M.

846 Raimondi, P., B.J. Gallagher, R. Ehrlich, J.H. Messmer, and G.S. Bennett.

847 Ramey, H.J., Jr., A. Kumar, and M.S. Gulati.

848 Ranney, M.W.

849

850

851

852

853

854

Riaz, M., P.L. Blackshear, and H.0. Pfannkuch. Rose, K.S.

Schaetzle, W.J., C.E. Brett and J.M. Ansari.

Schaetzle, W.J., C.E. Brett and D.M. Grubbs.

Schaetzle, W.J., C.E. Brett and D.M. Grubbs.

Schaetzle, W.J., C.E. Brett and D.M. Grubbs.

855 Schaetzle, W.J., C.E. Brett and D.M. Grubbs. 
856

857

858

859

860

861

862

863

864

865

866

867

868

869

870

871

872

873

874

875

876

877

878

879

880

881

882

883

884

885

886

887

888

889

890

891

892

893

894

895

896

897

898

899

900

901

902

903

905

906

Schaetzle, W.J., C.E. Brett and D.M. Grubbs. Schaetzle, W.J., C.E. Brett and D.M. Grubbs. Schaetzle, W.J., L.R. Fang, C.E. Brett and D.M. Grubbs. Schaetzle, W.J., J.E. LeCroy, M.S. Seppanen and C.E. Brett. Schumacher, M.M. (ed). Shee ly, C.Q. Spotila, J.R.

Stalkupsss, F.I.

Stecher, P.G. (ed).

Strange, L.K. and A.W. Talash.

Water Information Center.

Sudol, G.A., R.F. Harrison and H.J. Ramey, Jr.

Swet, C.J. and W.J. Masica.

Tinker, G.E., R.W. Bowman, and G.A. Pope.

Trantham, J.C., H.L. Patterson, Jr., and D.F. Boneau.

U.S. Department of Energy, Division of Energy Storage Systems.

Wagner, O.R.

Walton, W.C.

U.S. Patent Documents.

Weber, K.J., P.H. Klootwijk, J. Konieczek, and W.R. Van der Vlugt.

Witherspoon, P.A., I. Javande I, S.P. Neuman, and R.A. Freeze.

Meyer, C.F.

Katter, L.B. and R.L. Hoskins.

Schrock, V.E. and A.D.K. Laird.

Sepaskhah, A.R., L. Boersma, L.R. Davis and D.L. Slegel.

Foxworthy, B.L. and C.T. Bryant.

Schaetzle, W.J. and C.E. Brett.

Blevins, T.R. and R.H. Billingsley.

Bodvarsson, G., R.W. Couch, W.T. MacFarlane, R.W. Tank, and R.M.

Whitsett.

Brothers, R.C. and C.P. Wilhite.

Brown, J.S.

Brummett, W.M., A.S. Emanuel, and J.D. Ronquille.

Burt, R.A., F.A. Haddenhorst, and J.C. Hartford.

Carpenter, D.H. and J.B. Davies.

Casamajor, A.B.

Charroppin, P., J. Despois, J.C. Fauconnier, and F. Nougarede.

National Water Well Association.

Cox, D., R.V. Westermark, and G. Johnson.

Danielson, H.H., W.T. Paynter, and H.W. Milton, Jr.

Ridgeway, J. and C.S. Projanski.

Felsenthal, M. and F.J. Gangle.

Ferris, J.G., D.B. Knowles, R.H. Brown, and R.W. Stallman.

Flewitt, W.E.

Ford, W.O., Jr. and W.F.N. Kelldorf.

Business Publishers, Inc.

Gilliland, H.E. and F.R. Conley.

Gogarty, W.B.

National Water Well Association.

Harrar, J.E., F.E. Locke, C. Otto, L.E. Lorensen, W.P. Frey and E.0. Snell.

$$
\text { Haugen, A.K. and I.L. Purdy. }
$$


Electric Information Publications.

Hem, J.D.

Holm, L.W.

Hutchison, S.0.

Johnson, C.E.

Jones, S.C. and W.O. Roszelle.

Kavernen Bau-Und Betrieds-GMBH.

Keese, J.A. and A.L. Oden.

Keese, J.A. and A.L. Oden.

Kruger, P. and H.J. Ramsey, Jr.

Kumar, A.

Meehan, D.N., D.E. Menzie, and H.B. Crichlow.

Margen, $P$.

$0 i 1$ and Gas Journal.

McMillion, L.G.

Mercer, J.W. and C.R. Faust.

$0 i l$ and Gas Journal.

TRANE Air Company.

Nelson, C.G.

Noran, D.

0 il and Gas Journal.

Perry, $H$.

Ramey, H.J., Jr.

Rande 11, J.E.

Robertson, D.C. and C.H. Kelm.

Sharp, M.K. and R.I. Loehrke.

Shippee, D.

Smith, R.S.

Snyder, R.E.

Sparlin, D.D.

Schulte and Koerting Company.

Cayais, J.L., M.E. Hayes, R.S. Schechter and W.H. Wade.

Tinsley, J.M. and J.R. Williams, Jr. Toronyi, R.M. and S.M. Farouq-A1i.

U.S. Department of Energy, Technical Information Center.

U.S. Environmental Protection Agency.

$0 i 1$ and Gas Journal.

Week 1 y Energy Report.

Weeks, S.G. and G.F. Farris.

Wenze1, L.K.

Williams, T.E.

Wilder Construction Co., Inc.

Wilson, $K$.

Wintz, W.A., R.G. Kazmann, and C.G. Smith, Jr.

Bouwer, $H$.

Hooper, F.C. and C.R. Attwater.

Hooper, F.C., C.R. Attwater, A.P. Brunger, R.J.D. Cook, and J.D. McClenahan.

Larson, S.P., S.S. Papadopulos, and J.W. Mercer.

Margen, P., B. Perers, and K.G. Spangberg.

Berend, J.E.

Harrar, J.E., C.H. Otto, Jr., S.B. Deutscher, R.W. Ryon, and 


\section{G.E. Tardiff.} Locke, F.E., L.B. Owen, and R. Quong. 
1011 Gregory, M.W., H. Shaw, R.S. Reed and A. DeCagna.

1012 Gwyther, D.N.

1013 Hall, E.H. and J.A. Eibling.

1014 Hanna, W.T. and W.J. Frederick, Jr.

1015 Hausz, W., R.K. Anand and N. LaMarche

1016 Hawkes, D.A. and S.B. Hosegood.

1017 Heitner, K.L.

1018 Hockett, R.S. and R.W. Serth.

1019

1020

Hoffman, H.W., R.J. Kedl, and C.J. Swet.

1022

Jaske, R.T., M.H. Karr, and C.J. Touhill.

1023

1024

1025

1026

1027

Kennedy, A.S., C. Lee, A.A. Davis, and H.A. Davis.

Kugeler, K., M. Kugeler, H.D. Niessen, and H. Hohn.

Lee, D.A.

Lohse, D. and G. Taft.

Lundberg, W.L. and F. Wojnar.

1028

Margen, P.H.

1029

Marianowski, L.G. and H.C. Maru.

1030

1031

1032

1033

1034

1035

1036

1037

1038

1039

1040

1041

1042

1043

1044

1045

1046

1048

1049

1051

1052

1053

1054

1055

1056

Martinez, R.H. and J.M. Henry.

Metz, P.D.

Michel, J.W.

Molz, F.J., A.D. Parr, and P.F. Andersen.

Moore, G.L.

Moriarty, M.P.

Muzzy, J.D. and J.T. Sommerfeld.

Offenhartz, P.O. and F.C. Brown.

Patani, A. and U. Bonne.

Phillips, W.F. and R.A. Pate.

Pierce, B.L., F.R. Spurrier, and M.K. Wright.

Powe 11, W.R.

Quade, R.N.

Ramakumar, R. and J.C. Beaver.

Reed, R.D.

Reimels, R. and J.E. Howell.

Richards, W.D. and W.S. Chiu.

Ritl and, P.D. and B. Coffay.

Saari, R.

Sakhuja, R. and G. Mileris.

Sevcik, V.J.

Sliwinski, B.J., A.R. Mech and T.S. Shih.

Sperry, R.E., S. Toney, and D.J. Shade.

Steele, B.L.

Sullivan, D.

1057

Szego, J. and F.W. Schmidt.

1058

1059

1060

1061

1062

1063

Electrical World

Timmerman, R.W.

Uehara, $H$.

Urdaneta-Bohorquez, A.H.

Van Schelt, J.E., Jr.

Waters, E.D., E.W. Saaski and W.R. Martini.

Watkins, J.J.

1064

Willingham, R.C. 
1065

1066

1067

1068

1069

1070

1071

1072

1073

1074

1075

1076

1077

1078

1079

1080

1082

1083

1084

1085

1086

1087

1089

1090

1091

1093

1094

1095

1096

1097

1098

1099

1100

1101

1102

1103

1104

1105

1106

1107

1108

1109

1110

1111

1112

1113

1114

1115

1116

Funnel1, J.E. and E.J. Wolfe.

Yee, W.C.

Alexander, $F$.

Aller, P., W. Saylor, G. Schmidt, and D. Wein.

Carnegie, E.J., P.W. Niles, J.A. Hoffman, W.B. Stine, and R.E. Boche.

Chapman, H.L.

Chemical Week.

Clark, A.F., W.L. Ahlgren, J.A. Day, W.C. Dickinson, and W.G. Gensler.

Close, D.J.

Close, D.J.

Close, D.J., R.V. Dunkle, and K.A. Robeson.

Close, D.J. and T.L. Pryor.

Cropsey, M.G.

Daniels, D.G. and M.F. Merriam.

Duvall, G.D.

Ervin, G.

Garton, R.R. and A.G. Christianson.

Glenn, D.R., R.L. McCarthy, and J.D. Schelkopf.

Gruen, D.M., R.L. McBeth, M. Mendelsohn, J.M. Nixon, F.

Schreiner, and I. Sheft.

Kruger, P. and H.J. Ramsey, Jr.

Hubbard, M.W.

Mother Earth News.

Kirchner, R.P. and E. Stamper.

Kosaka, M. and M. Asahina.

Krause, $C$.

Libowitz, G.G. and Z. Blank.

Lior, N.P., S. Ayyaswamy, J. O'Leary, K.W. Kauffman, and H. Yeh. Lorsch, H.G.

Magnuson, E.E.

McDonald, C.F. and D.L. Vrable.

Nakajima, Y.

Nicholson, E.W. and R.P. Cahn.

Nielsen, C.E. and A. Rabl.

Rao, S.K. and R.K. Suri.

Read, W.R. and J. Czech.

Santoleri, J.J.

Sarkar, S., B.N. Mittal, S.C.L. Tewari.

Saulnier, B., N. Chepurniy, S.B. Savage, and T.A. Lawand.

Schmidt, E.W. and P.A. Lowe.

Smith, G.A. and A.M. Severson.

Stepler, R.

Styris, D.L., R.J. Zaworski, O.K. Harling, and J. Leshuk.

Industrial Heating.

Venkatesetty, H.V. and R.T. LeFrois.

Yudow, B.D., N.R. Baker, R.R. Tison, and P.F. Swenson.

Boeing Engineering and Construction.

Intertechnology Corporation.

Midwest Research Institute.

Acurex Corporation, Aerotherm Division. 
1117 Asbury, J.G. and A. Kouvalis.

1118 Ayerbe, A., C. Giddey, and B. Maslowski.

1119 U.S. Dept. of Energy, Office of Industrial Applications and Commercialization.

1120 Battelle Memorial Institute.

1121 Carr, J.H., P.J. Hurley, and P.J. Martin.

1122 Cturtnicek, T.E., R.J. McCormick, R.W. Serth, A. Wojtowicz, and

1123

1124

1125

1126

1127 D.L. Zanders.

1128

1129

1130

1131

1132

1133

1134

S Dean, T.S.

Washington Scientific Marketing, Inc.

Divine, T.E., D.P. Alzheimer, and W.F. Smith.

Dow Chemical Company.

The Engineering Foundation.

Teledyne Brown Engineering, System Division.

Flemings, M.C., R.S. Busk, W.A. Barnes, and J.P. Clark (ed.).

Gatts, R.R., R.G. Massey, and J.C. Robertson.

Hoffman, H.W., R.J. Ked1, and R.A. Duscha.

McDonne 11 Douglas Astronautics Company.

Rogan, J.E., D.A. Carey, S.M. Hatasaka, D. Quan and R.E. Snyder. Drexel University, United Technologies Research Center and Mathematica, Inc.

1135 Drexel University, United Technologies Research Center and Mathematica, Inc.

1136 International Gas Union, Int'1 Institute of Refrigeration and Institute of Gas Technology.

1137 International Gas Union, Int'1 Institute of Refrigeration and Institute of Gas Technology.

1138

1141

1142

1143

Jaeger, F.A., D.G. Beshore, F.M. Miller, and E.M. Gartner.

Kauffman, K.W. and Y.C. Pan.

Kreider, K.G. and M.B. McNeil (eds).

1144

1145

1146

1147

1148

1149

1150

1151

1152

1153

Leiby, C.C. and T.G. Ryan.

Lundberg, W.L. and J.A. Christenson.

Mitche11, P.D., B.P. Gupta, K.L. Curtner, and R.A. Rausch.

Neal, J.W. and W.F. Savage (eds).

Nwude, J.K., H.L. Brown, B.B. Hame1, and A.J. Roman.

Washington Scientific Marketing, Inc.

Los Alamos Scientific Laboratory.

University of Maryland, Department of Mechanical Engineering.

Robertson, S.J. and P.O. McCormick.

Rocket Research Company.

U.S. Energy Research and Development Administration, Division of Solar Energy.

1154 International Solar Energy Society - UK Section.

1155 U.S. Executive Office of the President, Office of Management and Budget.

1156 Battelle Columbus Laboratories and Honeywel1.

1157 Turner, R.H.

1158 Allen, R. (ed).

1159 National Consumer Research Institute.

1160 Allen, R.D.

1161

1162

Baker, E.T., Jr. and J.R. Wall.

Blatz, E.H., S.W. West, and S.R. Ash. 
1163 Bloyd, R.M., Jr.

1164 Bloyd, R.M., Jr.

1165 Bodvarsson, G.

1166 Bodvarsson, $G$.

1167 Bodvarsson, G.

1168 Bodvarsson, G.

1169 Bodvarsson, G.

1170 Bodvarsson, G. and J.M. Hanson.

1171 Briggs, J.E.

1172 Brown, D.W. and J.D. Hem.

1173 Cederstrom, D.J., E.H. Boswell, and G.R. Tarver.

1174 U.S. Department of Energy.

1175 Eakin, T.E., D. Price, and J.R. Harri11.

1177 Lawrence Berkeley Laboratory.

1177 a Lee, K.H., D. Pridmore, M. Hoversten, and H.F. Morrison.

1177 aa Benson, S.M., C.B. Goranson and R.C. Schroeder.

1177 ab Benson, S.M., C.B. Goranson, J. Haney, D.G. McEdwards, T.N. Narasimhan and R.C. Schroeder.

1177 ac Pruess, K., R.C. Schroeder, P.A. Witherspoon and J.M. Zerzan.

1177 ae Lippmann, M.J., P.A. Witherspoon and H.A. Wollenberg.

1177 af Lippmann, M.J., G.S. Bodvarsson and P.A. Witherspoon.

1177 ag Tsang, C.F., G.S. Bodvarsson, M.J. Lippmann and J. Rivera R.

1177ah Howard, J.H., A.N. Graf and P.C. Van de Kamp.

1177 ai Simkin, T.L., J.E. Noble and W.J. Schwarz.

1177 aj Howard, J.H. and W.J. Schwarz.

1177 ak Lippmann, M.J., C.F. Tsang and P.A. Witherspoon.

1177 al Tsang, C.F., T. Buscheck, D. Mangold and M.J. Lippmann.

1177 am Narasimhan, T.N. and B.Y. Kanehiro.

1177 ao Narasimhan, T.N. and B.Y. Kanehiro.

1177 aq Somerton, W.H., A. Ghaffari, R. Greenwald, V. Hoang, F. Martinez-Baez, H.J. Su and L. Wong.

1177 ar Pitzer, K.S., D.J. Bradley, P.Z. Rogers and J.C. Peiper.

1177 as Nei1, J. M. and J.A. Apps.

1177 e Morrison, H.F., N.E. Goldstein, M. Hoversten, G. Oppliger and C. Riveros.

1177f McEvilly, T.V., B. Schechter and E.L. Majer.

1177h Goldstein, N.E., H.A. Wollenberg, H. Bowman and E. Mozley.

1177 i McEvilly, T.V., B. Schechter and E.L. Majer.

$1177 \mathrm{j}$ Majer, E.L. and T.V. McEvilily.

$1177 \mathrm{~K}$ Corwin, R.F. and H.F. Morrison.

11771 Wi1t, M.J. and N.E. Goldstein.

$1177 \mathrm{~m}$ Gamble, T.D., W.M. Goubau, N.E. Goldstein and J. Clarke.

1177 n Granne11, R.B., D.W. Tarman and N.E. Goldstein.

11770 Tleimat, B.W., A.D.K. Laird, H. Rie and I.C. Hsu.

$1177 \mathrm{p}$ Beaulaurier, L.0.

$1177 \mathrm{q}$ Silvester, L.F.

1177 r Fulton, R.L.

1177 s Pines, H.S.

1177 t Davey, J.V. and J.H. Howard.

1177 u Pope, W.L.

1177v Juprasert, S.

1177w Narasimhan, T.N. and W.A. Palen. 
1177y Mlodinow, L.D. and C.F. Tsang.

$1177 z$ Narasimhan, T.N., S. Juprasert and G.S. Bodvarsson.

1178 Eissenberg, D.M. and H.W. Hoffman.

1179 Foxworthy, B.L.

1180 U.S. Geological Survey.

1181 U.S. Geological Survey.

1182 U.S. Geological Survey.

1183 Green, J.H.

1184 Hellstrom, G., C.F. Tsang, and J. Claesson.

1185 Hem, J.D.

1186 Hem, J.D.

1187 Hem, J.D., C.E. Roberson, C.J. Lind, and W.L. Polzer.

1188 Johnson, A.I.

1189 Johnson, A.I., R.C. Pri11, s and D.A. Morris.

1190 Kahan, C.V.

1191 Katz, M.L.

1192 Kimme 1, G.E.

1193 Kreith, F., R. Boehm, J. Mitchell and R. Bannerot (eds).

1193c Kurosaki, Y. and R. Viskanta.

$1193 f$ Shamsundar, N. and R. Srinivasan.

1193g Lilleleht, L.U.; L.M. Fafarman and J.T. Beard.

1193 h Clark, E.C. and C.C. Hiller.

1193i Coste11o, V.A., S.S. Melsheimer and D.D. Edie.

1193j Marshal1, R.H.

1193k Scmerton, C.W. and I. Catton.

1194 Lofgren, B.E.

1195 U.S. Department of Energy, Asst Secr for Energy Technology and Asst Secr for Environment.

1196 Maclay, R.W. and G.R. Schiner.

1197 Mangold, D.C., C.F. Tsang, M.J. Lippmann, and P.A. Witherspoon.

1198 Morrel1, G.0. and R.E. Collins.

1199 Ogata, A.

1200 Papadopulos, I.S.

1201 Parker, A.J., Jr., D.E. Cassel, R.E. Hedden, and T.N. Veziroglu.

1202 Peaudecerf, P. and J.P. Sauty.

1203 Piety, R.G. and B.F. Wiley.

1204 Poland, J.F.

1205 Potter, R.W., D.R. Shaw, and J.L. Haas, Jr.

1206 Price, D. and T. Arnow.

1207 Prill, R.C., A.I. Johnson, and D.A. Morris.

1208 Lawrence Berkeley Laboratory, Earth Sciences Division.

1209 Reeder, H.0.

1210 Sauty, J.P., A.C. Gringarten, and P.A. Landel.

1211 Dudgeon, C.R. and P.S. Huyakorn.

1212 Shapiro, L.

1213 Sinnott, A. and E.M. Cushing.

1214 Stallman, R.W.

1215 Stottlemyre, J.A., R.P. Smith, and R.L. Erikson.

1216 Takasaki, K.J.

1217 Taylor, 0.J.

1218 Terry, J.E., R.L. Hosman, and C.T. Bryant.

1219 Thomas, H.E. and D.A. Phoenix. 
Turcan, A.N.

1221

1222

Drexel University, United Technologies Research Center and Mathematica, Inc.

Kaplan, S.I.

1234 Jacobs Engineering Co.

1235 Jacobs Engineering Co.

1236 Oak Ridge National Laboratory.

1237 U.S. Energy Research and Development Administration.

Bramlette, T.T.

1239 Kalhammer, F.R.

1240 Pimental, K.D., D.H. Stuermer, and M.M. Moody.

1241 Glenn, E.E., M.L. Slusser, and J.L. Huitt.

1242 Tsang, C.F., C.B. Goranson, M.J. Lippmann, and P.A. Witherspoon.

1243 Plantikow, U. and R. Jank.

1244 Gunn, T.L.

1245

1246

1247

1248

1249

Chern, W.S., and R.E. Just.

JRB Associate, Inc.

Jaehne, H., M.A. Karnitz, A. Rubin, and P.H. Margen.

Sapsford, C.M.

1250 California, (St), Dept of Water Res and Univ of CA, Dept of Civil Eng and Geotech Eng.

Dilworth, Secord, Meagher and Associates, Limited.

Canada Mortgage and Housing Corp.

Brown, D.L. and W.D. Silvey.

Bouwer, H., R.C. Rice, J.C. Lance and R.G. Gilbert.

Bouwer, $\mathrm{H}$.

Bodvarsson, G. and J.M. Hanson.

Bodvarsson, G.

Try Agricultural Research Service.

Telkes, M. and E. Raymond.

Heronemus, W.E. and J.G. McGowan.

Matthews, C.S. and D.G. Russell.

Sugawara, A. and Y. Yoshizawa.

1264 Whitehead, W.R. and E.J. Langhetee.

1265 Lilleleht, L.U., L.M. Fafarman, and J.T. Beard.

1266 Davison, R.R., W.B. Harris, and D.L. Reddell. 
Peterson, F.L.

Powe 11, W.R.

International Association of Scientific Hydrology and Unesco. Holzer, T.L. U.S. Nuclear Regulatory Commission and U.S. Department of Interior.

\section{U.S. Nuclear Regulatory Commission and U.S. Department of}

Interior.

Deans, H.A.

Signor, D.C., D.J. Growitz and W. Kam.

Price, C.E.

National Swedish Board for Technical Development.

Hooper and Angus Associates Ltd.

Hooper and Angus Associates Ltd.

Bear, J.

Bear, J.

Lamers, M.D.

Anderson, C.J.

Rambo, J.T. and B.L. Coles.

Rousseau, W.F., S.S. Sussman, R.N. Castleton and J.T. Rambo.

Sussman, S.S. and W.F. Rousseau.

Rousseau, W.F., J.T. Rambo, R.N. Castleton and S.S. Sussman.

Calm, J.M.

Calm, J.M. and G.R. Sapienza.

Crane, R.E., H.G. Lorsch and R.G. Werden.

Rocket Research Company.

Wade, D.W., B.C. Tramme 1, B.S. Dixit, D.C. McCurry and B.A. Rindt.

Dubin, F.S., A. Halfon and P. Herzog.

Honeywell Incorporated.

Tison, R.R., N.R. Baker, B.D. Yudow, D.L. Sala, T.D. Donakowski and P.F. Swenson.

Sitzer, S., R. Moden and P. Don Victor.

Newcomb, R.C.

Hem, J.D.

Walling, F.B., and L.E. Ottis, Jr.

Hogenson, G.M., and B.L. Foxworthy.

Durfor, C.N., and E. Becker.

Segaser, C.S.

Brown, K.C.

Peart, R.M., and G.H. Foster.

Bryan, W.L.

U.S. Dept. of Energy, Asst. Secr. for Energy Tech., Div. of Geothermal Energy.

Eissenberg, D.M.

Parr, A.D., F.J. Molz, P.F. Andersen and J.C. Warmán.

Schaetzle, W.J., C.E. Brett and M.S. Seppanen.

Crow, N.B.

Water Well Journal Publishing Co.

Edesess, M., J. Henderson and T.S. Jayadev.

Molz, F.J., A.D. Parr, P.F. Andersen and V.D. Lucido.

Galley, J.E. (ed).

Guyer, E.C., J.G. Bourne, L. Paglia and D.H. Walker. 
1315 Argonne National Laboratory, Oak Ridge National Laboratory and Trinity University.

1315a Hooper, F.C.

1315aa Schnurr, N.M. and J.W. Williamson.

$1315 \mathrm{ab}$ Talwar, R.

1315c Metz, P.D.

$1315 d$ MacCracken, C.D.

$1315 \mathrm{f}$ Short, T.H., W.L. Roller and H.M. Keener.

$1315 \mathrm{~h}$ Lorsch, H.G. and K.W. Kauffman.

$1315 i$ Curran, H.M. and S. Heibein.

1315k Beard, J.T. and L.U. Lilleleht and F.A. Iachetta.

13151 Burns, P. and C.B. Winn and J. Leflar.

13150 McGarity, A.E.

$1315 r$ Wittenberg, L.J. and M.J. Harris.

$1315 \mathrm{~s}$ Yang, K.T. and M. Delich.

1315t Bose, J.E. and C.W. Ledbetter and J.R. Partin.

1315w Owen, J.M. and E.W. Wilder.

1315y Mills, L.G. and H.E. Remmers.

1316 United Nations.

1318 Schaetzle, W.J., and C.E. Brett.

1319 Chaturvedi, S., and R.W. Porter.

1320 Zuck, J.C.

1321 Oak Ridge National Laboratory.

1322 U.S. Department Of Energy, Assistant Secretary for Conservation and Solar Energy.

1323 Calm, J.M.

1324 Harrar, J.E., F.E. Locke, C.H. Otto, Jr., L.E. Lorensen, W.P. Frey.

1325 Jones, R., R. Krajewski and E. Dennehy.

1326 U.S. Department of Energy.

1327 U.S. Department of Energy.

1328 Murphy, L.M.

1329 Powel1, J.D., and J.R. Powel1.

1330 Johnson, A.B., Jr., and B. Francis.

1331 Morgan, M.T., and G.A. West.

1332

1333

1334

1335

1336

1337

1338

1339

1340

1341

1342

1343

1344

1345

Schiff, L.

Hausz, W.

Colsher, C.S. and A.R. Evans.

Warner, D.L., L.F. Koederitz, A.D. Simon and M.G. Yow.

Air Conditioning, Heating and Refrigeration News.

Onodera, T.

Rima, D.R., E.B. Chase and B.M. Myers.

Foxworthy, B.L.

Adams, M.V.

Water Well Journal Publishing, Co.

Wettermark, G., and J. Kowalewska.

American Geological Institute.

Oregon Institute of Technology.

1346

Aerospace Corp., Environment and Conservation Directorate. Laity, W.W., D.T. Aase, W.J. Apley, S.P. Bird, J.W. Currie, M.K. Drost, S.C. Schulte, M. Jannol, A. Sutey and T.A. Williams.

1347 Fugro, Inc. and Washington State University. 
1348 Avdonin, N.A.

1350 Hackett, C.E.

1351 Carlson, R.C.

1352 Erikson, R.L., and K.M. Drupka.

1353 Eissenberg, D.M.

1354 Doughty, C., D. McEdwards and C.F. Tsang.

1355 Furman, E.R.

1356 Bahadur, S.

1357 Electric Power Research Institute.

1358 Minor, J.E.

1359 Molz, F.J., A.D. Parr and P.F. Andersen.

1360 Argonne National Laboratory, Oak Ridge National Laboratory and Trinity University.

1360a Allen, C.P. and G. Clark.

1360 aa Hedden, R.E. and D.E. Cassel.

1360 ac Scaringe, R.P.

$1360 \mathrm{~b}$ Clark, G. and C.P. Allen.

$1360 \mathrm{~m}$ Edie, D.D. and S.S. Melsheimer and J.C. Mullins.

1360n Green, N.D., W. Keith and R. Watson.

13600 Haas, W.R., F.A. Jaeger and M.T. Howerton.

1360 q Lin, E.I.H., W.T. Sha and A.E. Michaels.

$1360 r$ Poling. B.E.

1360 t Sowe11, E.F.

$1360 u$ Spencer, D.L.

$1360 \mathrm{v}$ Von Fuchs, G.

1360 z Whitaker, R.B., G.H. Jenkins, G.L. Ball and I.0. Salyer.

1361 Argonne National Laboratory, Oak Ridge National Laboratory and Trinity University.

1362 Hooper, F.C., J.D. McClenahan, J.D. Cook, F. Baylin, R. Monte, S. Sillman.

1363 McCabe, J.E. and D.D. Huxtable.

1364 Eberle, M. and J.L. Persons.

1365 Vetter, 0.J., D.A. Campbe11, and M.J. Walker.

1366 Warner, D.L. and J.H. Lehr.

1367 Wapora Inc.

1368 Johnson, A.B.,Jr., W.J. Bailey, R.E. Schreiber, and F.M. Kustas.

1369 Warner, D.L.

1370 Friedman, M.

1371 Grove, D.B., W.A. Beetem and F.B. Sower.

1372 White, R.E. and W.C. Blackburn.

1373 Elkins, L.F.

1374 U.S. Department of Energy, Division of Solar Applications.

1375 Cigni, U., A. Giovannoni, E. Luschi and M. Vidali.

1376 Cigni, U., F. Fabbri, and A. Giovannoni.

1377 Bleakley, W.B.

1378 Johnson Division, UOP Inc.

1379 Johnson Division, UOP Inc.

1380 Johnson Division, UOP Inc.

1381 Johnson Division, UOP Inc.

1382 Johnson Division, UOP Inc.

1383 U.S. Department of Energy and NASA Lewis Research Center. 


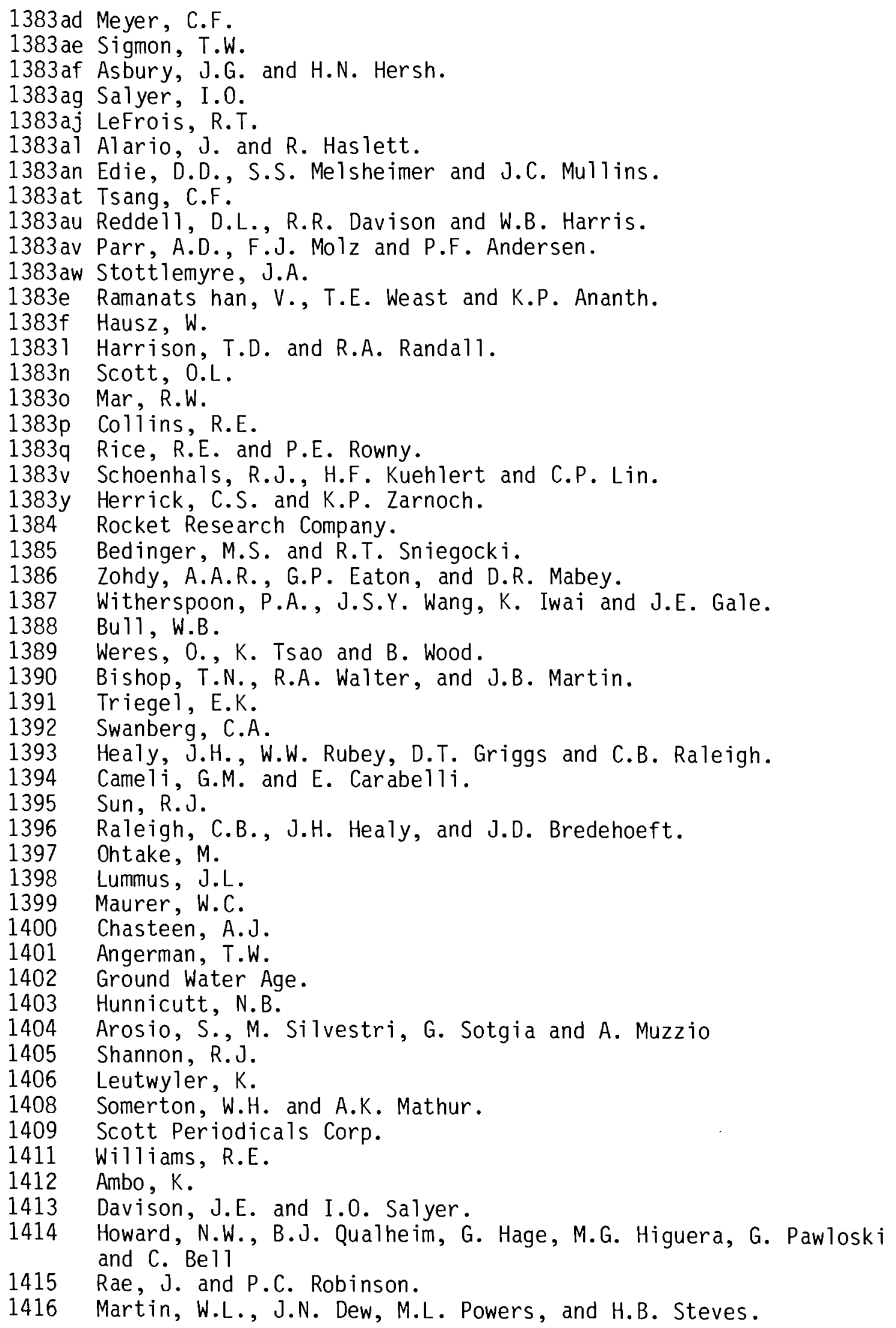


1417 Prill, R.C. E.T. Oaksford and J.E. Potorti.

1418 Mori, Y. and W. Nakayama.

1420 Garcia-Bengochea, J.I. and R.0. Vernon.

1421

1422

1423

1424

1425

1426

1427

1428

1429

1430

1431

1432

1433

1434

1435

1436

1437

1438

1439

1440

1441

1442

1443

1444

1445

1446

1447

1448

1449

1450 Austin, A.L.

Shelton, J.

Kutateladze, S.S., V.N. Moskvicheva, and Y.M. Petin.

Mercado, S.

Wahl, E. and I. Yen.

Chase, C.A. and P.M. O'Dell.

Vecchioli, J., H.F.H. Ku and D.J. Sulam.

Elder, W.J.

Elder, W.J.

Busse, F.H. and D.D. Joseph

Loddo, M.

Loscutoff, W.V.

Reffstrup, J.

Reffstrup, J.

Hodgk inson, D.P.

Hardee, J.

Radosevich, L.G.

Lichtler, W.F., D.I. Stannard and E. Kouma.

American Nuclear Society

Tam, S.W., C.A. Blomquist and G.T. Kartsounes.

Beshore, D.G., D.G. Raynor and M.G. Barth

Utah Roses, Inc.

Heise1, J.E. and J.R. Gonzalez

Flower, J.E.

Reil1y, R.W.

Wyman, C.E., R.J. Copeland, J.D. Wright and F. Baylin.

Martin, J.F. and H.W. Hoffman

Aydelotte, S.R.

Leshuk, J.P., R.J. Zaworski, D.L. Styris, and 0.K. Harling. Jenkins, $N$.

1451 Hourmanesh, M., R. Hourmanesh and D.B. Elmer.

1452 Trescott, P.C., G.F. Pinder and S.P. Larson.

1453 International District Heating Association.

1453c Kirvela, K.

1453d Saleta, V.A., R.H. Tourin and R.P. Ulfstam.

$1453 \mathrm{f}$ Guenther, K.L.

1453h Vandermolen, J.H.C.

$1453 \mathrm{~m}$ Yeoman, J.C.

1453 n Sundberg, R.E., R. Leas and J.0. Kolb.

14530 Nurmi, H.E.

1454 International Dis strict Heating Association.

1454 a Kurz, M.G.

1454c 01iker, I. and A.M. Rubin.

1454k Dwyer, P.R.

14541 Mayotte, R.J.

1454 s Les, J.G.

1455 Kunze, J.F. and R.C. Stoker.

1456 Frysinger, G.R.

1457 Pacific Northwest Laboratory, Battelle. 
1458 Engelke, C.E.

1460 Delaney, J.M. and H.C. Helgeson.

1461 Westermann, $\mathrm{J}$.

1462 Villas, R.N. and D. Norton.

1463 Ingri, N., W. Kakolowicz, L.G. Sillen and B. Warnvist.

1464

1465

1467

1468

1469

1470

1471

1472

1473

1474

1475

Knight, J.E.

Izatt, R.M., D. Eatough, J.J. Christensen and C.H. Bartholomew.

Wallace, G.G. (ed)

Consultant Review Team.

Calm, J.M. and G.R. Sapienza

U.S. Department of Energy, Argonne National Lab, and Univ. of

Illinois-Chicago Circle.

Finn, L.

Schoe 11, G.

Margen, P.H. and R. Roseen.

Lawrence Livermore Laboratory.

1476 Hill, J., J. Harrar, C. Otto, S. Deutscher, H. Crampton, R.

Grogan and $V$. Hendricks.

1477 Borst, W.L. and J.L. Kretsch.

1478 Hampe1, V.E.

1479 Hampel, V.E., S.K. McGrogan, L.E. Gallo, and J.E. Swanson.

1480 Toth, W.J. and F.C. Paddison.

1481 Prater, L.S.

1482 American Institute of Aeronautics and Astronautics.

1482 aa Keller, J.G. and R.C. Schmitt.

1482 an Smith, R.D.

1482 ao Marks, S.B.

1482 ao Palmour, H., B.M. Gay and R.L. Cochrane.

1482 ap Thomson, W.B., A.Z. Frangos and T.H. Springer.

1482bx Miller, R.L.

1482cs Feurer, D.A.

1482ct Greenberg, J.S.

1482cw Weast, T.E., L.J. Shannon and K.P. Ananth.

1482cx Cease, M.E.

1482ee Lamb, J.P., G.F. Polansky and S.P. Bradley.

1482 Shaw, D., A.P. Bruckner and A. Hertzberg.

1482x Black, R.A.

1482y Lienau, P.J., J.W. Lund, G.G. Culver and C.V. Higbee.

1483 American Institute of Aeronautics and Astronautics.

1484 American Institute of Aeronautics and Astronautics.

1485 Roseen, R. and B. Perers.

1486 Copeland, R.J., M.E. Karpuk and J.L. UI Iman.

1487 Solar Energy Research Institute.

1488 Jorda, R.M.

1489 U.S. Department of Energy, Office of Program Management Support.

1490 NASA Lewis Research Center.

1491 Lawrence Livermore Laboratory, Energy and Resource Planning

Group.

1493 Messer, P.H., D.S. Pye and J.P. Gallus.

1494

1495

Reeder, H.O.

Sasman, R.T. 
1496 Allman, D.W., D. Goldman and W.L. Niemi.

1497 Jorda, R.M.

1498 Quong, R., F. Shoepflin and N.D. Stout.

1499 Netherton, R. and L.B. Owen.

1500 Hasbrouck, R.T., L.B. Owen and R. Netherton.

1501 Jorda, R.M.

1502 Jorda, R.M.

1503 Snoeberger, D.F. and J.H. Hill.

1504 Davidson, E.S.

1505 Weeks, E.P.

1506 NASA Lewis Research Center, Thermal Storage Project Office.

1507 Scott Periodicals Corp.

1508 Allen, R.D. and P.J. Gutknecht.

1509 Erikson, R.L., J.A. Stottlemyre and R.P. Smith.

1510 Meyer, C.F. and W. Hausz.

1511 Water Well Journal Publishing Co.

1512 Lawrence Berkeley Laboratory, Earth Sciences Division.

1513 Business Publishers.

1514 Pacific Northwest Laboratory, Battelle.

1515 Sandia National Laboratories.

1516 NASA Lewis Research Center.

1517

1518

1519

1520

1521

1522

1523

1524

1525

1526

1527

1528

1530

1531

1532

1533

1534

1535

1536

1537

1538

1539

1540

1541

1542

1543 Copeland, R.J., J.D. Wright and C.E. Wyman.

Solar Energy Research Institute.

Oak Ridge National Laboratory.

Sydansk, R.D.

Bayl in, F. and M. Merino.

Bayl in, F. and S. Sillman.

Childs, S.w.

Bear, J.

Bloomster, C.H., B.A. Garrett-Price and L.L. Fassbender.

$\mathrm{RPC}$, Inc.

$\mathrm{RPC}$, Inc.

Lippmann, M.J. and C.F. Tsang.

Mansure, A.J.

Task Force 11.

President's Water Policy Implementation, Task Force 9.

Task Force $5 \mathrm{a}$.

Dvoracek, M.J. and S.H. Peterson.

Tsang, Y.W. and C.F. Tsang.

Sheinbaum, I.

Reeder, H.O., W.W. Wood, G.G. Ehrliech and R.J. Sun.

Owen, L.B., E. Raber, C. Otto, R. Netherton, R. Neurath and L.

Allen.

Jorda, R.M.

Meyer, C.F. (ed)

Electric Power Research Institute.

Johnson Division, UOP Inc.

Johns Hopkins University, Applied Physics Laboratory.

1544 U.S. Department of Energy, Office of Advanced Conservation

Technologies Branch, Thermal and Chemical Storage Br.

1544a Gurevich, M.

1544aa White, S.H., U.M. Twardoch and M.M. Bower. 
1544 ab DeVan, J.H. and P.F. Tortorel1i.

1544 ac Osteryoung, R.A. and H. Fernandez.

1544 ad Gross, R.J. and R.W. Harrigan.

1544 ae Chaney, S., N. Hayden and J.A.C. Humphrey.

1544 af Manvi, R.

1544 ag Zimmerman, W.F., L.E. Stacy and G.C. Wesling.

1544 ah Polzien, R.E.

1544 ai Katter, L.B.

1544 aj Edde, $\mathrm{H}$.

1544al 01 iker, I.

1544 ap Clark, E.C., D.K. Carlson and 0.M. Morgan.

1544 aq Offenhartz, P.0.

1544 ar Standley, W.R., R. Gorman, P.S. Moritz and T.J. O'Gorman.

1544 as Clinch, M.

1544b Martin, J.F.

1544C Sigmon, T.W., J.H. Davidson, J.M. Doster, J.F. Martin, J.A.

Edwards.

1544d Rizzuto, J.E.

1544 e Hersh, H.N.

$1544 f$ Salyer, I.0. and J.E. Davidson.

$1544 \mathrm{~g}$ Ternes, M.P.

1544 h Ternes, M.P.

$1544 \mathrm{i}$ Solomon, A.D.

$1544 \mathrm{j}$ Giese, R.F.

1544k Schoenhals, R.J., C.P. Lin, H.F. Kuehlert and S.H. Anderson.

15441 Lorsch, H.G.

$1544 \mathrm{~m}$ Gay, B.M., H. Palmour and R.L. Cochrane.

1544 n Reid, R.L. and A.F.G. Bedinger.

15440 Wyman, C.E.

1544 p Wright, J.D.

$1544 \mathrm{q}$ Copeland, R.J.

1544 s Petri, R.J. and T.D. Claar.

1544t Alario, J. and R. Haslett.

1544u Chubb, T.A., J.J. Nemecek, D.E. Simmons and R.J. Veith.

1544v Birchena11, C.E.

1544w Goldenberg, D.

$1544 z$ Carling, R.W.

1545 Kreid, D.

1546 Kemper, W.D. and W.R. Walker.

1547 Abdel-Wahed, R.M., P.F. Emerson, P.L. Blackshear and M. Riaz.

1548 Behnia, M., and R. Viskanta.

1549 Coleman, W.R.

1550 Calamai, A., P. Ceron, G. Ferrara and G. Manetti.

1551 Schatz, J.F., P.W. Kasameyer, J.A. Cheney.

1552 Taylor-Beard, J., F.A. Iachetta, L.U. Lilleleht and J.W. Dickey.

1553 Electric Power Research Institute, The EPRI Planning Staff.

1554 U.S. Energy Research and Development Administration, Division of

Building and Industry.

1555 Electric Power Research Institute.

1556 Electric Power Research Institute.

1557 Huyakorn, P.S., G.F. Pinder, C.R. Faust and J.W. Mercer.

1558 Mercer, J.W. and C.R. Faust. 
1559 Mercer, J.W. and C.R. Faust.

1560 Mercer, J.W., S.P. Larson and C.R. Faust.

1561 Faust, C.R. and J.W. Mercer.

1562 Mercer, J.W. and C.R. Faust.

1563 Faust, C.R. and J.W. Mercer.

1564 Miller, I. and K. Roman.

1565 Koenig, E.F. and A.B. Cambel.

1566 Esbensen, T.V. and V. Korsgaard.

1567 Water We11 Journal Publishing Co.

1568 Ontario, Ministry of Education.

1569 Raymond, J.R.

1570 National Water We 11 Association.

1571 U.S. Department of Energy, Assistant Secretary for Energy Technology.

1572 Berntsson, T., P.A. Franck, L. Jacobson, B. Modin, and P. Wilen.

1573 Calm, J.M.

1574 Hoffmann, M.

1575 Schipper, L.

1576 Lawrence Berkeley Laboratory, Earth Sciences Division.

1577 U.S. Department of Energy, Division of Energy Storage Systems.

1578 Geothermal Resources Council.

$1578 \mathrm{fq}$ Spencer, S.G.

1579 Geothermal Resources Counci1.

1579bu Hayashi, M., T. Mimura and T. Yamsaki.

$1579 \mathrm{cq}$ Jorda, R.M.

1580 Moyers, J.C. and E.C. Hise.

1581 MCC Associates, Inc.

1582 MCC Associates, Inc.

1582 aa Thoms, R.L.

1582ab Brandshaug, T. and A.F. Fossum.

1582 ac Fossum, A.F.

1582 ad Rudd, N.

1582 ae Stottlemyre, J.A.

$1582 \mathrm{~b}$ Cherne, J.

1582c Stern, L.I.

1582d University of Minnesota.

1582h Reilly, R.W., D.R. Brown and H.D. Huber.

$1582 \mathrm{~m}$ Stottlemyre, J.A., C.H. Cooley and G.J. Banik.

1582n Cooley, C.H., L.B. Owen, C.K. Blair and G.J. Banik.

$1582 p$ Tsang, C.F.

1582r Blahnik, D.E.

1582s Hendrickson, P.L.

1582u Drost, M.K., R.W. Reil1y, J.K. Young and F.R. Zaloudek.

$1582 \mathrm{v}$ Lessard, R.D. and W.A. Blecher.

1582w Driggs, C.L.

1582y Doherty, T.J.

1583 Hendrickson, P.L.

1584 Claesson, J., B. Eftring, and G. Hel1strom (eds).

1585 China, People's Republic of.

1586 Smith, L. and R.A. Freeze.

1587 Gelhar, L.W., A.L. Gutjahr and R.L. Naff.

1588 Charbeneau, R.J. and R.L. Street. 
1589

1590

1591

1592

1593

1594

1595

1596

1597

1598

1599

1600

1601

1602

1603

1604

1605

1606

1607

1608

1609

1610

1611

1612

1613

1614

1615

1616

1617

1618

1619

1620

1622

1623

1624

1625

1626

1627

1628

1629

1630

1631

1632

1633

1634

1635

1636

1637

1638

1639

1640
Lappillonne, B.

Michaels, A.I.

Schneider, R.

Pfannkuch, H.O. and M.H. Edens.

Swanson, S.R., G.M. Sandquist., J.K. Kunze.

Saha, $H$.

Tsang, C.F., M.J. Lippmann and P.A. Witherspoon.

Riaz, M.

Hibsch, G. and A. Kreft.

Sagar, B. and S.R. Singh.

Bentley, C.B.

Pezdirtz, G.E.

Lawrence Livermore Laboratory, Earth Sciences Division.

Tsang, C.F., T. Buscheck and C. Doughty.

Tsang, C.F., D. Hopkins and F. Hellstrom.

Tsang, C.F., F.J. Molz and A.D. Parr.

Energy Systems, Inc.

Smith, A.J.

Blahnik, D.E.

Wilson, M.R.

Mercer, J.W. and C.R. Faust.

Katter, L.B.

Bligh, T.P.

Brown, D. and W.D. Silvey.

Glaser, C.W.

INTERA Environmental Consultants, Inc.

Bergqvist, B. and J.G. Holmberg.

Weast, T. and L. Shannon.

LeFrois, R.T. and A.K. Mathur.

Geraghty, J.J., D.W. Miller, R. Van der Leeden, F.L. Troise.

Claesson, $\mathrm{J}$.

Claesson, J. and M. Johansson.

Claesson, $\mathrm{J}$.

Javande 1, I. and P.A. Witherspoon.

Defferding, L.J.

Pettitt, R.A.

Strawn, J.A.

Yeh, G.T.

Sinclair, A.R., F.J. Pittard and R.J. Hanold.

McConne 11, T.D.

Roach, F.

Santini, D.J. and E.P. Levine.

Pferdehirt, $W$. and N. Kron, Jr.

Anuskiewicz, T. and R. Meador.

Black and Veatch Consulting Engineers.

U.S. Dept. of Energy, U.S. Dept. Of Housing and Urban Dev. and Int' 1 District Heating Assn

The Trane Company.

The Trane Company.

The Trane Company.

The Trane Company.

The Trane Company. 


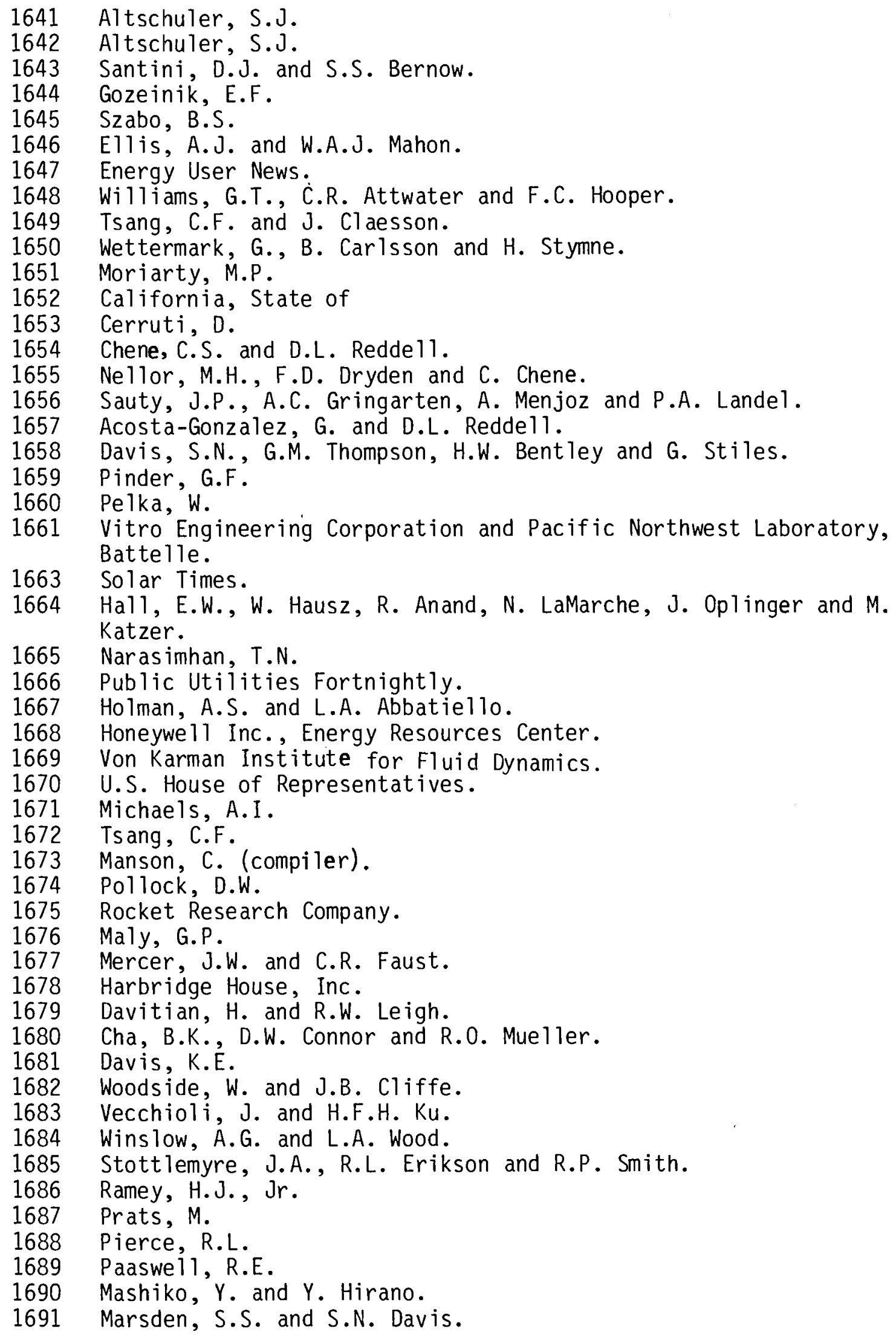




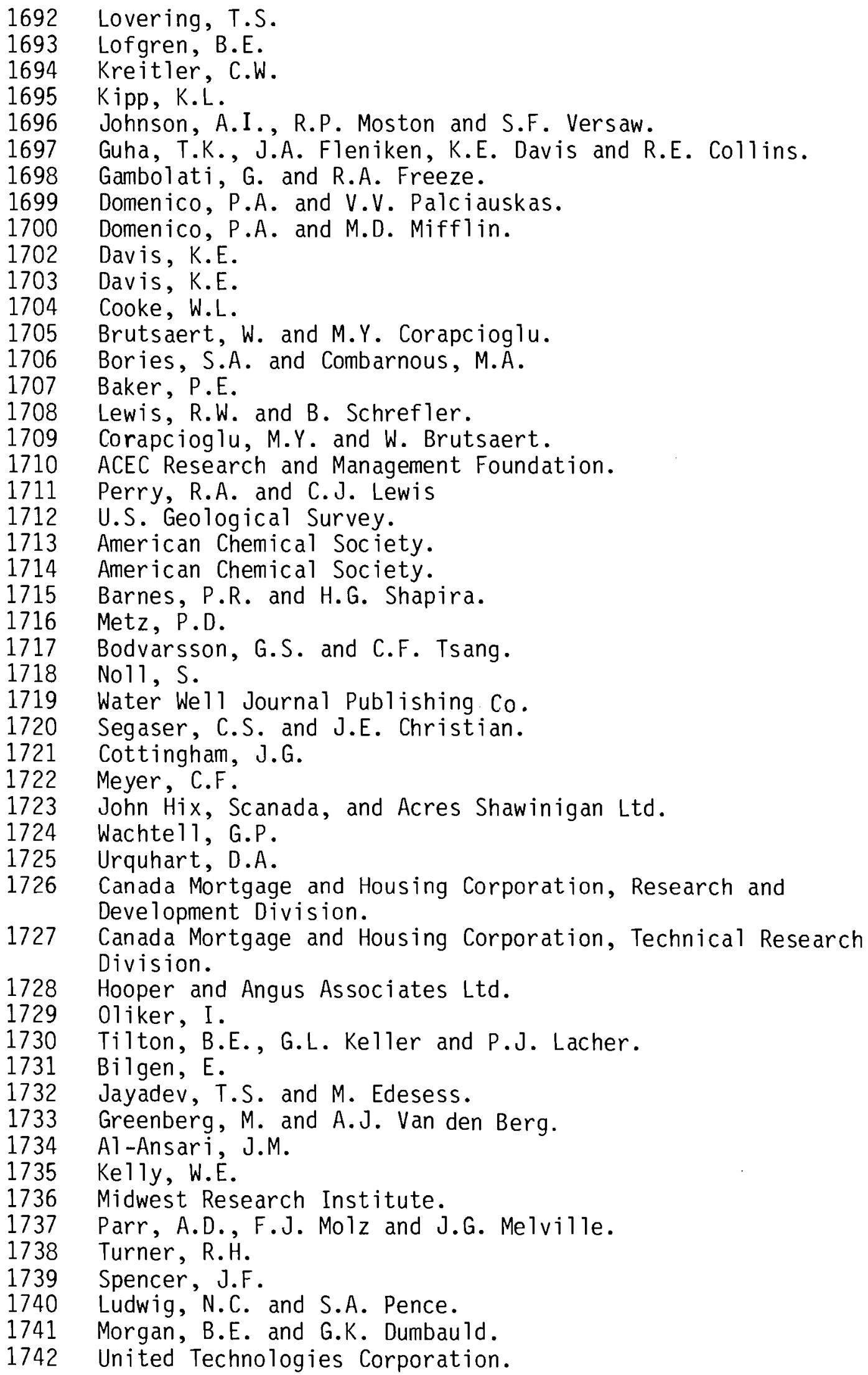


1743 Nuclear Research Centre.

1744s Claesson, $J$.

1745 Domanski, P. and G.E. Kelly.

1746 Syska, A.J. and A. Brzezinski.

1747 Kusuda, T. and T. Saitoh.

1748 Kestin, J., R. DiPippo. H.E. Khalifa and D.J. Ryley (eds).

1749 Hellstrom, G. and J. Claesson.

1750 Anderson, M.P.

1751 Stefan, H. and C.V. Nguyen.

1752 Reed, D.B. and D.L. Redde 11.

1753 Grubaugh, E.K. and D.L. Redde 11.

1754 Roback, J.J.

1755 Daly, C.J.

1756 Aguado, E.

1757 Gelhar, L.W., J.L. Wilson, A.L Gutjahr.

1758 Bachmat, Y., J. Bredehoeft, B. Andrews, D. Holtz and S.

Sebastian.

1759 Schertz, W.W.

1760 Powell, W.R. and C.E. Williams.

1761 Powel1, W.R. and C.E. Williams.

1762 Powe11, W.R. and C.E. Williams.

1763 Tang, D.H. and G.F. Pinder.

1764 Helistrom, G.

1765 Claesson, J. and G. Hellstrom.

1766 Claesson, J. and T. Bengtsson.

1767 Claesson, J., B. Eftring and G. Hellstrom.

1768 Reilly, R.W., D.R. Brown and H.D. Huber.

1769 Prater, L.S., J.R. Eliason and V.E. Hampel.

1770 Frind, E.0.

1771 Rubin, H. and C. Roth.

1773 U.S. Geological Survey.

1774 Jorgensen, D.G.

1775 Reed, J.E.

1776 Segesman, F.F.

1777 Rouve, G. and H. Lutkestratkotter.

1778 Spencer, S.G. and D.M. Callan.

1779 Mid-Continent District Study Comm. on Cementing Practices and Testing of 0 il-Well Cements.

1780 Schaetzle, W.J., C.E. Brett, D.M. Grubbs and M.S. Seppanen.

1781 D'Hooge, J.A., C.Q. Sheely, and B.J. Willi iams.

1782 Eilers, L.H. and R.L. Root.

1783 Gallus, J.P., D.E. Pyle and L.K. Moran.

1784 Kalousek, G.L. and S.Y. Chaw.

1785 Solar Energy Research Institute.

1785 ap Cluff, C.B. and R.B. Kinney.

1785bs Lin, E.I.H., W.T. Sha and S.L. Soo.

1786 Energy User News.

1787 U.S. Water Resources Counci1.

1788 Swet, C.J. and F. Baylin.

1789 Mustil1o, N. and A.C. de Digiacomo.

1790 Wittenburg, L.J. and M.J. Harris.

1791 Motovilov, Y.G. 


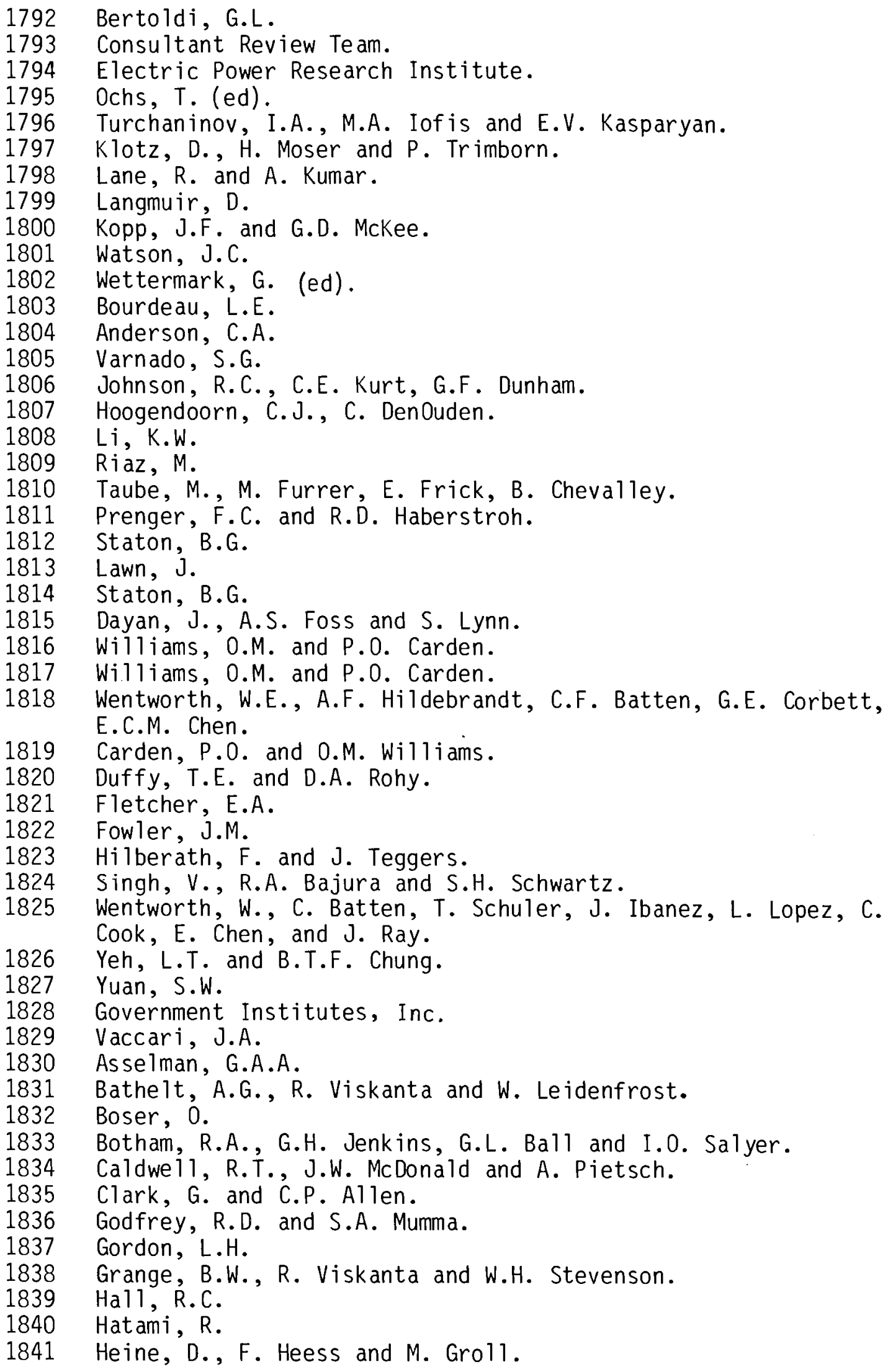




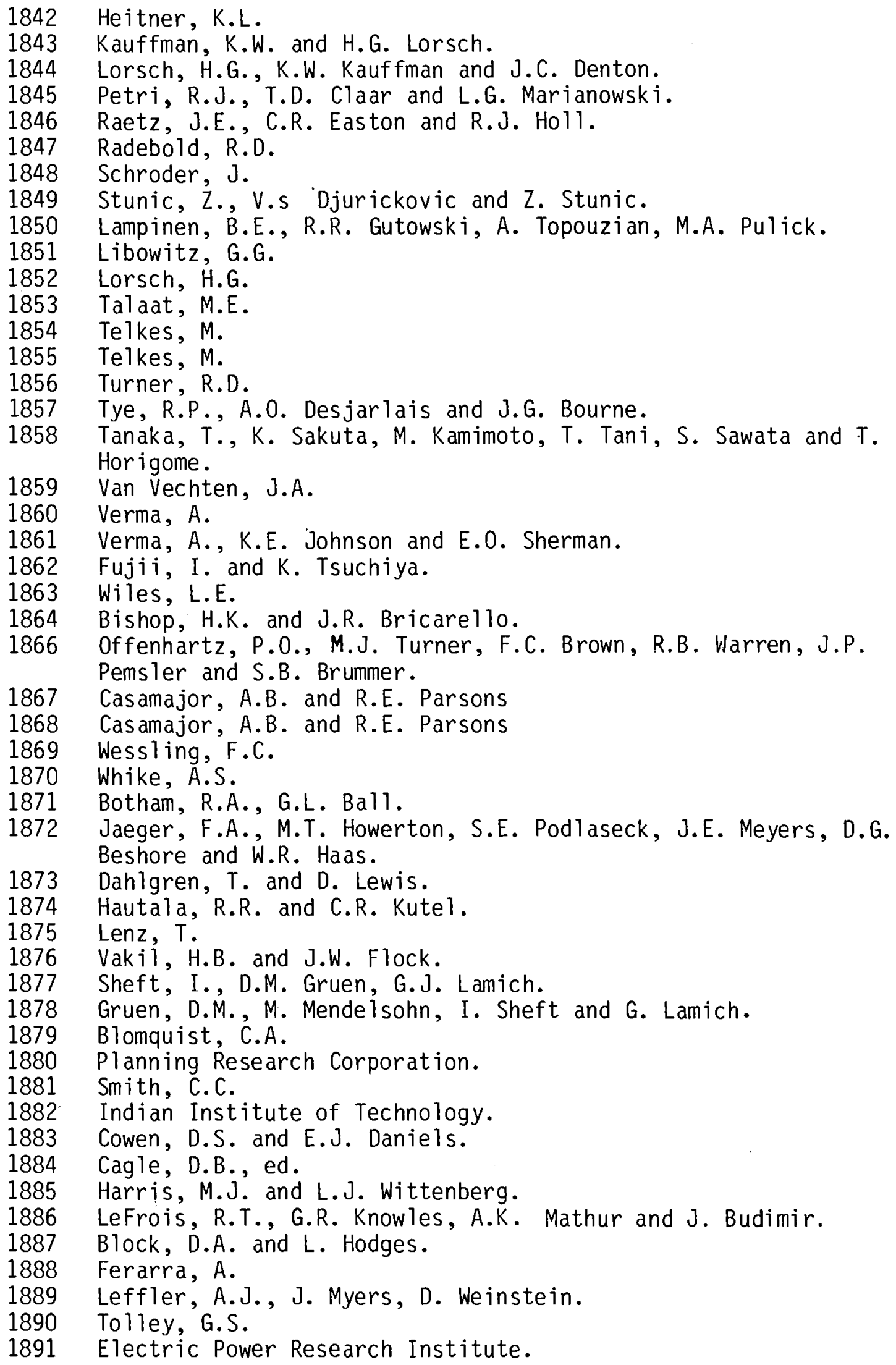


1892

1893

1894

1895

1896

1897

1898

1899

1900

1901

1902

1903

1904

1905

1906

1907

1908

1909

1910

1911

9999a

9999bx Esterka, F. and 0. Slama.

9999ca Wood, W.W.

9999cw Malcolm, R.L., G.R. Aiken, E.M. Thurman and P.A. Avery. 9999cx Mal low, W.A.

9999dc Chubb, T.A.

9999df Skougstad, M.W., M.F. Fishman, L.C. Friedman, D.E. Erdmann and S.S. Duncan.

9999di Wood, W.W.

9999dj Fishman, M.J. and E. Brown.

9999dk Brown, E., M.W. Skougstad and M.J. Fishman.

9999dq Karadi, G.M.

9999dr Republic Geothermal, Inc.

9999du Buscheck, T.E.

9999dw Wiscons in State Energy Office.

9999dx City of Piqua, Ohio.

9999dy Minnesota Energy Agency.

9999dz Ghaffari, A.

9999ea Fischer, L.S., C.W.J. Vankoppen, J.J. Puts.

9999eb Bose, T.E., C.W. Ledbetter, and J.R. Partin.

9999ec Ebeling, L., D.L. Reddel1, S. Tostengard, W.B. Harris, and R.R. Davison.

9999ed Schaetzle, W.J., C.E. Brett and D.M. Grubbs

9999ee International Solar Energy Society, UK Section.

9999ef Metz, P.D.

9999eg Vachaud, G. and J.Y. Ausseur.

9999r Tsang, C.F., G. Bodvarsson, M.J. Lippmann and R.J. Rivera. 


\section{DISTRIBUTION}

No. of

Copies

$\underline{\text { OFFSITE }}$

A. A. Churm

DOE Patent Division

9800 S. Cass Avenue

Argonne, IL 60439

John J. Brogan

DOE Office of Advanced Conservation Technologies

Washington, DC 20585

Arnold Epstein, Project Manager

CR-341, Forrestal Building

DOE

Washington, DC 20585

B. J. Gall agher

DOE Office of Advanced Conservation Technologies

Washington, DC 20585

T. Levinson

DOE Office of Advanced Conservation Technologies

Washington, DC 20585

G. F. Pezdirtz

DOE Office of Advanced Conservation Technologies

Washington, DC 20585

Veronica Rabl

DOE Office of Advanced Conservation Technologies

Washington, DC 20585

S. Strauch

DOE Office of Advanced Conservation Technologies

Washington, DC 20585

J. H. Swisher

DOE Office of Advanced Conservation Technologies

Washington, DC 20585
No. of

Copies

213 Technical Information Center

Fred J. Molz

School of Engineering

Auburn University

Auburn, AL 36830

Donald Langmuir

Department of Chemistry and Geochemistry

Colorado School of Mines

Golden, CO 80401

Louis Stern

Dames \& Moore

6 Commerce Drive

Cranford, NJ 07016

Krishnan Raman

Dubin-Bloome Associates, P.C.

312 Park Road

West Hartford, CT 06107

Walter Hausz

4520 Via Vistosa

Santa Barbara, CA 93110

Charles F. Meyer

1141 Cima Linda Lane

Santa Barbara, CA 93108

Chin Fu Tsang

Bldg 90, Room 1012-H

University of California

Lawrence Berkeley Laboratory

1 Cyclotron Road

Berkeley, CA 94720

5 Victor E. Hampel

Integrated Information Systems

Computation Dept., L-275

University of California

Lawrence Livermore Laboratory

P.0. Box 808

Livermore, CA 94550 
No. of

Copies

5 Richard A. Kawin

Mail Stop $L-275$

University of California

Lawrence Livermore Laboratory

P.0. Box 808

Livermore, CA 94550

5 Charles H. Lee

Midwest Research Institute

425 Volker Blvd

Kansas City, MO 64110

Michael P. Convery

Minnesota Department of Health

Water Supply and General

Engineer ing

717 SE Delaware Street

Minneapolis, MN 55440

Matt Walton

Minnesota Geological Survey

319 15th Avenue S.E.

Minneapolis, MN 55455

Bradley R. Sielaff

Minnesota Pollution Control Agency

Division of Water Quality

1935 West County Road B2

Roseville, MN 55113

National Aeronautics and Space Adminstration

Asst Adm for Energy Programs

Washington, DC 20546

National Science Foundation

Division of Advanced Energy

Research and Technology

Room 1140

1800 G Street, NW

Washington, DC 20550

Director

New York State Energy Research

\& Development Agency

Rockefeller Plaza

Albany, NY 12223
No. of

Copies

J. F. Martin

Oak Ridge National Laboratory

P.0. Box $Y$

Oak Ridge, TN 37830

Douglas D. Huxtable, Director

Energy R\&D

Rocket Research Company

York Center

Redmond, WA 98052

L. Radosevich

Sandia Laboratories, Livermore

P.0. Box 969

Livermore, CA 94550

W. G. Wilson

Sandia Laboratories, Livermore

P.0. Box 969

Livermore, CA 94550

Frank Baylin

Solar Energy Research Institute

1536 Cole Blvd

Golden, CO 80401

Char les Wyman

Solar Energy Research Institute

1536 Cole Blvd

Golden, CO 80401

Allan Michaels

Solar Thermal Storage Programs

Argonne National Laboratory

Building 362

9700 South Cass Avenue

Argonne, IL 60439

John F. Spencer

Department of Ecology

State of Washington

Olympia, WA 98504

J. M. Cherne

TRW

One Space Park

Redondo Beach, CA 90278 
No. of

Copies

William Waldrop

Assistant Branch Chief

Water Systems Development Branch

Division of Water Management

Tennessee Valley Authority

P.0. Drawer E

Norris, TN 37828

Craig Cooley

Terra Tek

University Research Park

400 Wakara Way

Salt Lake City, UT 84108

R. D. Davison

Department of Chemical

Engineer ing

Texas A\&M University

College Station, TX 77843

U.S. Army Corps of Engineers

Attn: Library

P.0. Box 59

Louisville, KY 40202

U.S. Department of Energy

Attn: Chief, APMBR

Division of Energy Storage Systems

Washington, DC 20545

U.S. Department of Energy

Attn: Director, Policy and Planning

Office of Conservation and Solar Applications

Washington, DC 20545

U.S. Department of Interior

Attn: Natural Resources Library

Serials Branch (G/E)

Washington, DC 20240

Kevin Billings, Legislative Assistant

Office of Congressman Sid Morrison 1330 Longworth Building

Washington, DC 20515
No. of

Copies

Robert D. MacNish,

District Chief

Arizona District

U.S. Geological Survey

Federal Building

Tucson, AR 85718

C. Everett Brett

School of Mines and Energy

Development

University of Alabama

P.0. Box 6282

University, AL 35486

Char lotte Hok

Institute of Water Resources

University of Alaska

Fairbanks, AK 99701

Stanley N. Davis

Department of Hydrology and Water Research

University of Arizona

Tucson, AZ 85705

Katherine Hed in

University of Minnesota

Minnesota Geological Survey

1633 Eustis Street

St. Paul, MN 55108

W. E. Soderberg

Program Director, ATES

University of Minnesota

Physical Plant Operations

200 Shops Bldg.

319 15th Avenue S.E.

Minneapolis, MN 55455

James W. Crosby III

Geology Department

Washington State University

Pullman, WA 99164

David L. Schreiber, Ph.D., P.E. Consulting Hydraulic Engineer

P.0. Box 1087

(c/0 The Colony)

Coeur d'Alene, ID 83814 
No. of

Copies

FOREIGN

Peter Wilen

Chalmers Institute of Technology

S-412 96 GOTEBORG

SWEDEN

Glynn Williams

Hooper and Angus Associates Ltd. 950 Yonge Street, Suite 502

Toronto M4W $2 \mathrm{J7}$

CANADA

E. Butow

Technische Universitat Berlin

Institut fur Kerntechnik

Marchstrabe 18

1000 Ber 1 in 10

WEST GERMANY

J. P. Sauty

Bureau de Recherches Geologiques et Minieres

Service Geologique National-E.A.U. B.P. 6009

45060 ORLEANS Cedex

FRANCE

A. Nir

The Weizmann Institute of Science

Rehovat

ISRAEL
No. of

Copies

ONSITE

DOE Richland Operations Office

H. E. Ransom

40 Pacific Northwest Laboratory

D. E. Blahnik

S. C. Blair

T. J. Doherty

J. R. Eliason

W. A. Frier

P. L. Hendrickson

C. T. Kincaid

L. D. Kannberg

W. V. Loscutoff

J. E. Minor

D. A. Myers

J. R. Raymond

R. W. Reilly

W. D. Richmond

L. S. Prater (5)

J. A. Stott lemyre

G. E. Wukelic

STES Library (12)

Technical Information (5)

Publishing Coordination (2) 